\title{
Alaska's Mineral Industry 1997
}

SPECIAL REPORT 52 Division of Geological \& Geophysical Surveys

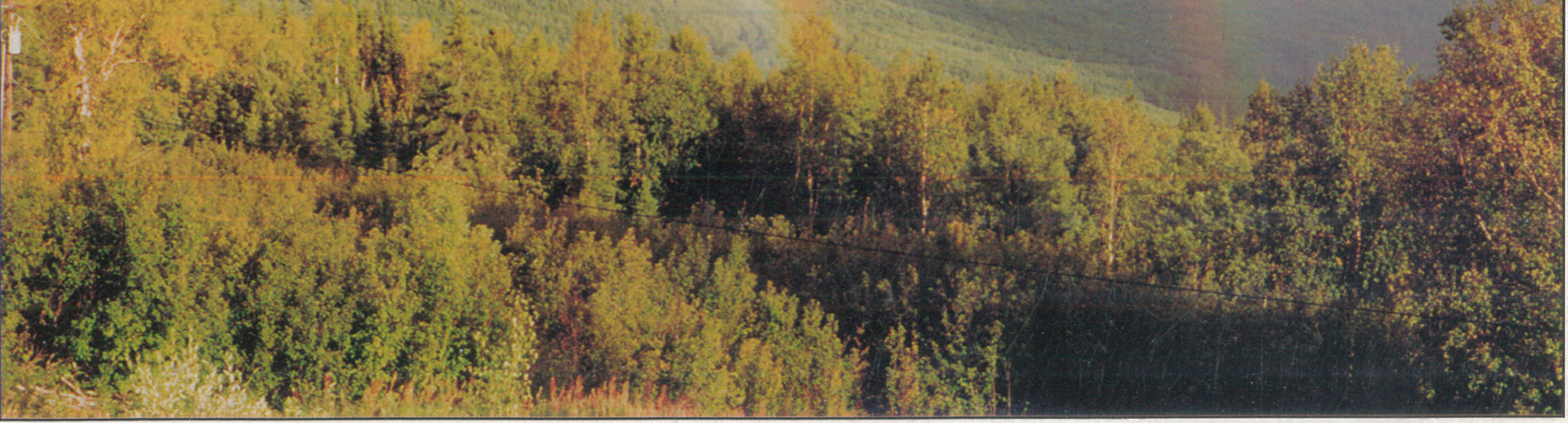

in cooperation with

Division of Trade \& Development

Division of Mining \& Water Management

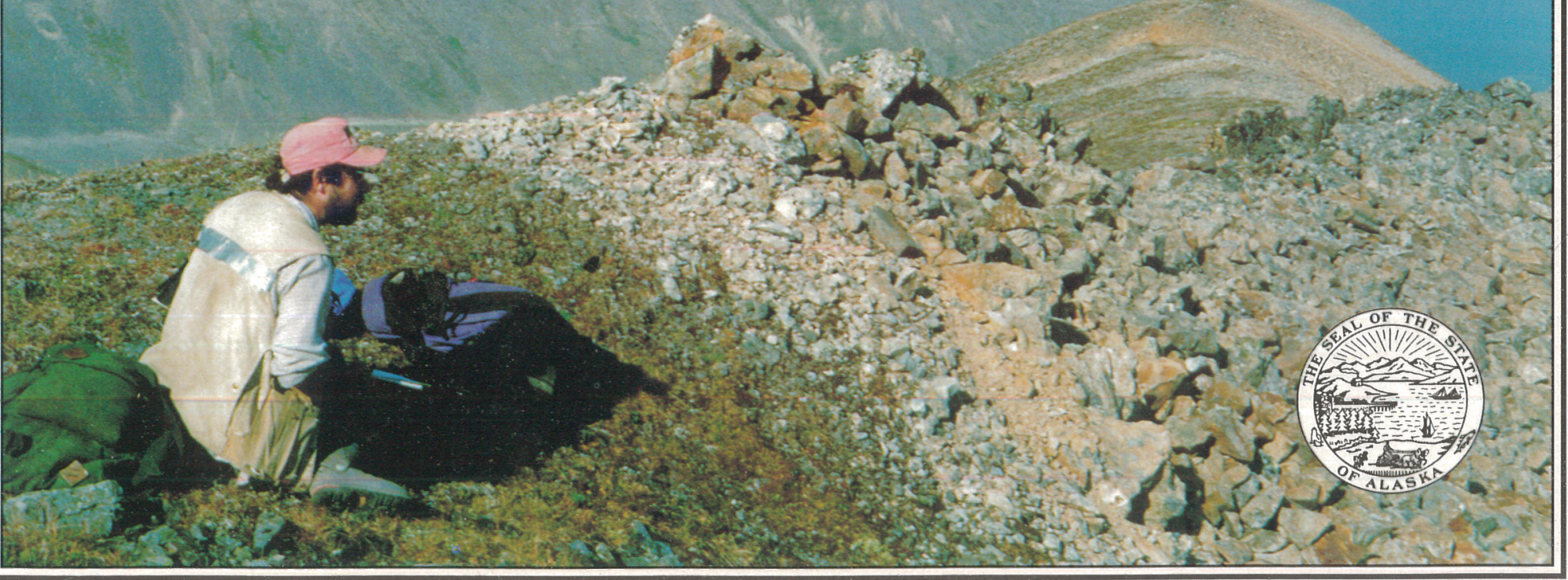


Alaska's Mineral Industry

$1 \bullet 9 \bullet 9$

R.C. Swainbank $\bullet \quad$ K.H. Clautice $\bullet \quad$ J.L. Nauman 


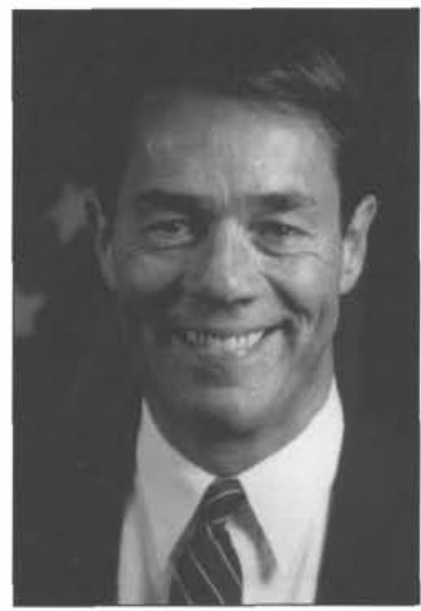

"Changes for the better" and "resurgence" are probably the best phrases that apply to Alaska's mining industry in 1997. Without question, Alaska is experiencing a world-class boom in mining that has attracted attention across the globe. In response, Alaska is open and ready for business and working to expedite the permit process. The Knowles-Ulmer administration is committed to working in partnership with the mining industry to do development right, which means protecting Alaska's air, water, and fish and wildlife habitat. Many factors account for the resurgence in Alaska's mineral industry including world-class quantities of minerals in vast unexplored areas strategically located in the global marketplace. These factors, coupled with mining innovations that make developments more cost effective and aggressive marketing of Alaska's enormous reserves, spell a bright future and prominent role for mining in Alaska's economy.

Governor Tony Knowles

1997 was another productive and exciting year for mining in Alaska. For the second consecutive year the total value of Alaska's mineral industry topped $\$ 1$ billion. Two new hardrock gold mines were commissioned in 1997 - at IIlinois Creek and at Fort Knox - and hardrock gold production exceeded that from placer mining for the first time in over 50 years. Greens Creek Mine reached full production in 1997, and the giant Red Dog Mine will soon increase production thanks to assistance from the Alaska Industrial Development and Export Authority. The year demonstrated continued optimism about Alaska's potential as a good place to do business. Strong exploration expenditure rates, which have led to permitting mines such as the Kensington, exciting new discoveries like Pogo, and doubling of the resource base at Pebble Copper and Donlin Creek, demonstrate Alaska's bright future for mineral development. (Photo shows Commissioner Debby Sedwick holding one of the first gold bars poured at the Fort Knox Mine near Fairbanks, December 20,1996. The mine produces about 1,000 ounces per day and employs 250 local workers.)

\section{Deborah B. Sedwick}

Commissioner, Department of Commerce \& Economic Development

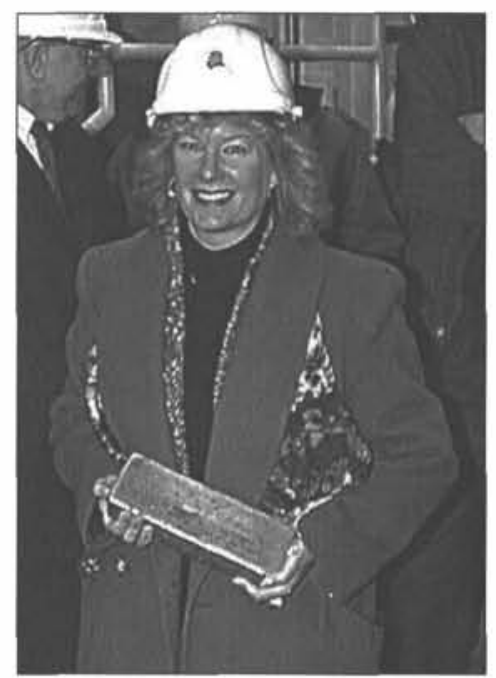

Despite falling metal prices and market scandals, there were a record number of mining locations established in 1997 in Alaska, many by junior companies whose existence depends on the ability to raise money on the stock markets. It is encouraging that the political climate and incentives in Alaska continue to attract the exploration investment necessary for the future well-being of the mining industry.

The administration recognizes that exploration and future production are vital, and that all aspects of the mining industry are important in Alaska, especially in rural areas where mineral development provides well-paid jobs. Much of Alaska is underexplored, but by acting as a partner to industry, providing data and assistance, the State looks forward to a bright future for the industry.

John T. Shively

Commissioner, Department of Natural Resources

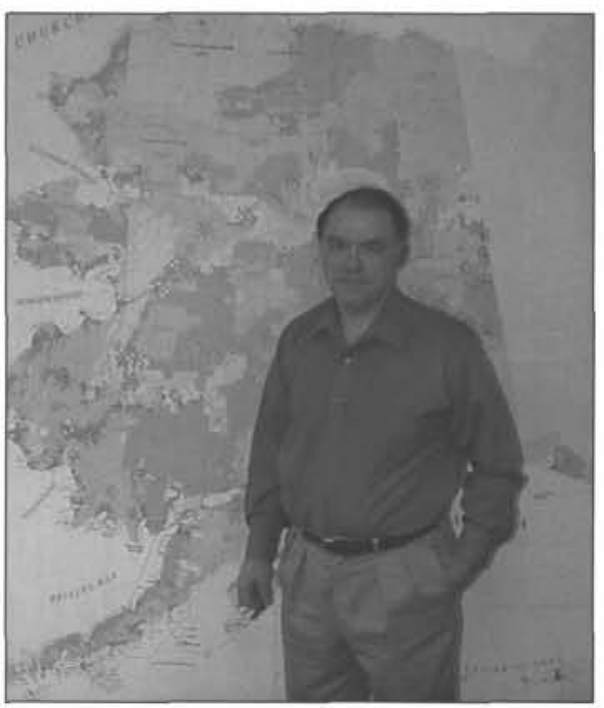


In 1997 the total investment in exploration and development in Alaska, together with the value of mineral production, was $\$ 1.162$ billion, up almost 13 percent from the $\$ 1.03$ billion the previous year. Exploration investment of $\$ 57.8$ million was up 30 percent from 1996, production of $\$ 936.2$ million was up 59 percent; these increases more than offset the 57 percent decline in development expenditure from \$394 million in 1996 to \$168.4 million in 1997.

Exploration was widespread throughout the state, and highlights include the addition of new reserves at the Red Dog Mine near Kotzebue, doubling of the resource at Pebble Copper near Iliamna and at Donlin Creek near Iditarod, identification of a 4.5-million-ounce high-grade gold resource at Pogo near Delta, and many exciting prospects throughout interior and southeastern Alaska.

Development projects included work on the mine and port at Red Dog, on the pit and leachpad at Illinois Creek south of Galena, on the tanks and tailings dam at Fort Knox, and permitting at the Kensington Mine near Juneau, which is now fully permitted.

Zinc production from Greens Creek and Red Dog accounted for 53 percent of all commodity value, followed by gold ( 22 percent), silver ( 8 percent), sand and gravel ( 6 percent), lead ( 5 percent), coal ( 4 percent), and rock, copper, peat, and jade. For the first time in over 50 years the amount of gold derived from hardrock mines ( 481,439 ounces) exceeded the 109,077 ounces derived from placer mines.

Alaska's Mineral Industry 1997, Special Report 52, is the 17th annual report produced jointly by the Departments of Natural Resources and Commerce \& Economic Development through their Division of Geological \& Geophysical Surveys (DGGS) and the Division of Trade \& Development (DTD) respectively. To save space, avoid confusion, and to conform to the units (ounces, tons, feet, and miles) that most miners use, metric units have been eliminated in this report. A conversion table can be found inside the back cover.

The report is designed to provide current, accurate, and technically reliable information about Alaska's mineral industry. The publication is made possible by the voluntary cooperation of government agencies, private industry, and individuals that provide information about their activities and operations. Without them this report could not exist, and we are grateful for their help. 


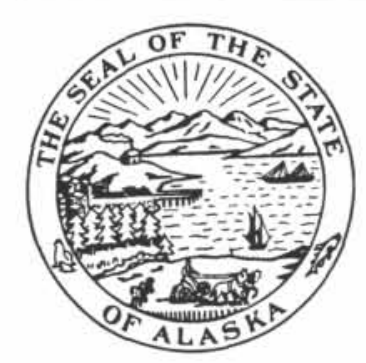

STATE OF ALASKA

Tony Knowles, Governor

\section{DEPARTMENT OF COMMERCE \& ECONOMIC DEVELOPMENT}

Deborah B. Sedwick, Commissioner

DIVISION OF TRADE \& DEVELOPMENT

Greg Wolf, Director

DEPARTMENT OF NATURAL RESOURCES

John T. Shively, Commissioner

\section{DIVISION OF GEOLOGICAL \& GEOPHYSICAL SURVEYS Milton A. Wiltse, Director and State Geologist}

\section{DIVISION OF MINING \& WATER MANAGEMENT \\ Jules Tileston, Director}

DGGS publications may be inspected at the following locations. Address mail orders to the Fairbanks office.

Alaska Division of Geological

\& Geophysical Surveys

ATTN: Geologic Communications

794 University Avenue, Suite 200

Fairbanks, Alaska 99709-3645

Elmer E. Rasmuson Library

University of Alaska Fairbanks

Fairbanks, Alaska 99775-1005
University of Alaska Anchorage Library

3211 Providence Drive

Anchorage, Alaska 99508

Alaska Resource Library

222 W. 7th Avenue

Anchorage, Alaska 99513-7589

Alaska State Library

State Office Building, 8th Floor

333 Willoughby Avenue

Juneau, Alaska 99811-0571

Publication of this report is required by Alaska Statute 41 "to determine the potential of Alaska land for production of metals, minerals, fuels, and geothermal resources; the location and supplies of groundwater and construction materials; the potential geologic hazards to buildings, roads, bridges, and other installations and structures; and shall conduct such other surveys and investigations as will advance knowledge of the geology of Alaska."

NOTE: Mention of any company or brand name does not constitute endorsement by any branch or employee of the State of Alaska. 


\section{CONTENTS}

Executive Summary ..................................................................................................................................... iii

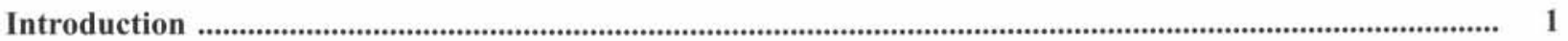

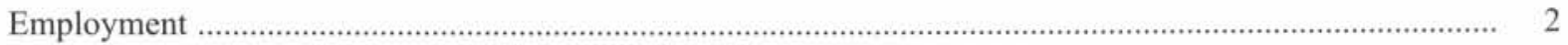

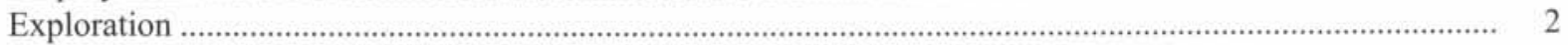

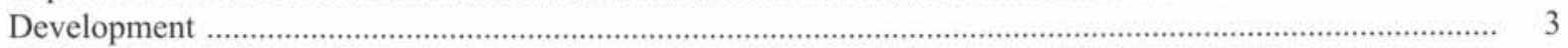

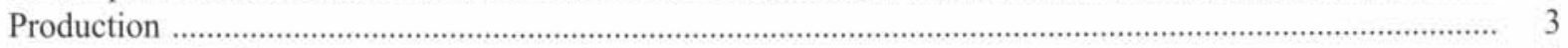

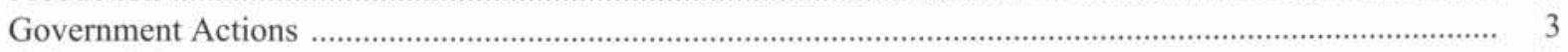

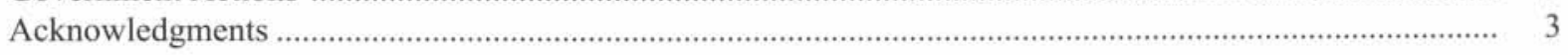

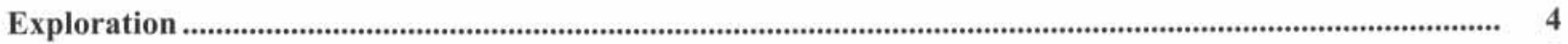

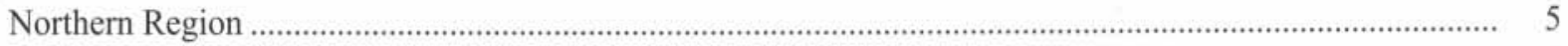

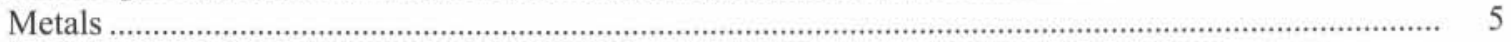

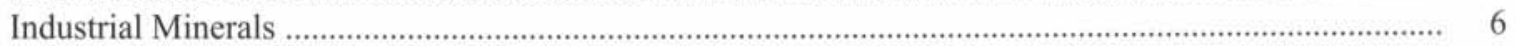

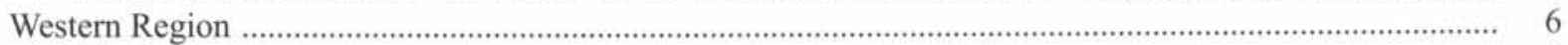

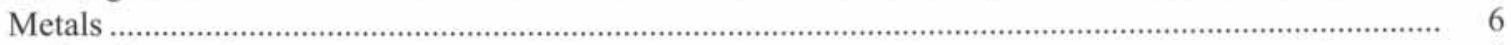

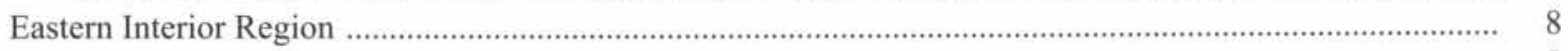

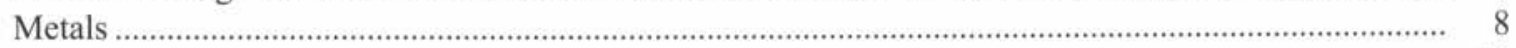

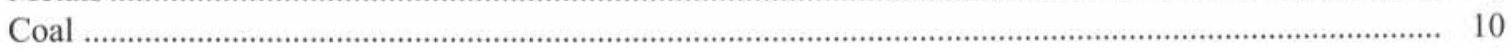

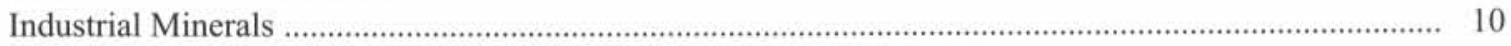

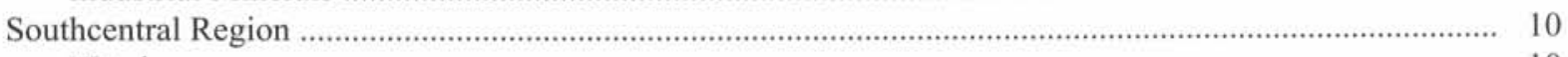

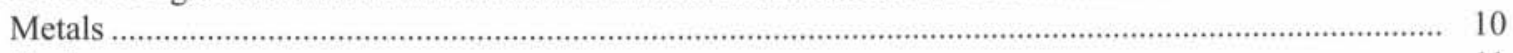

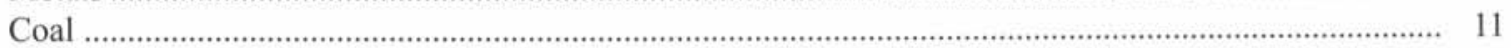

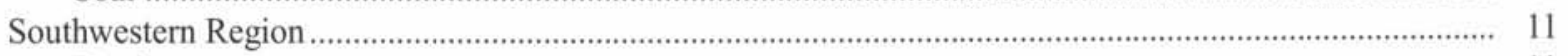

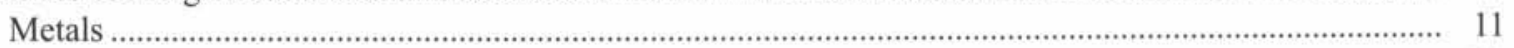

Alaska Peninsula Region ........................................................................................................... 12

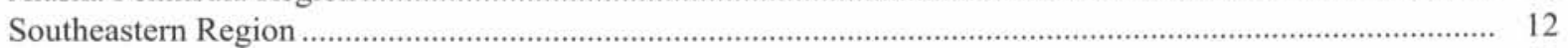

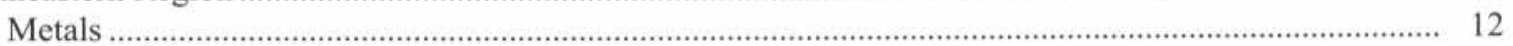

Development ........................................................................................................................................................... 13

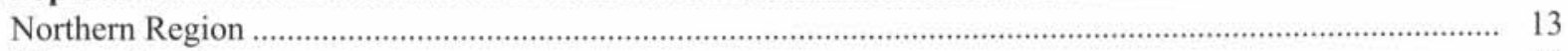

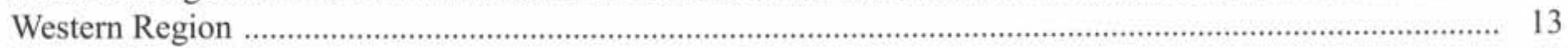

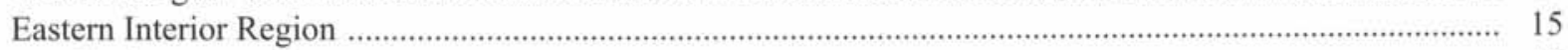

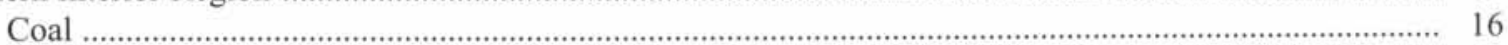

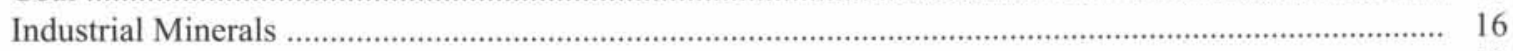

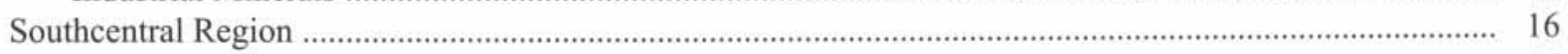

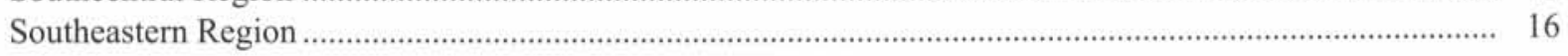

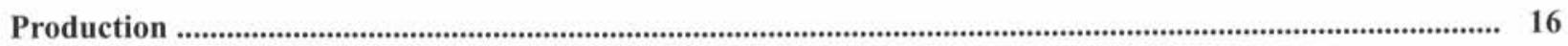

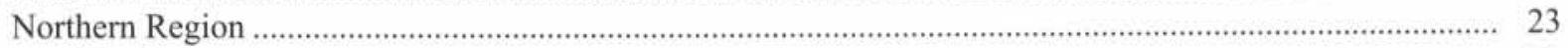

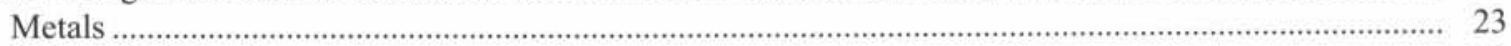

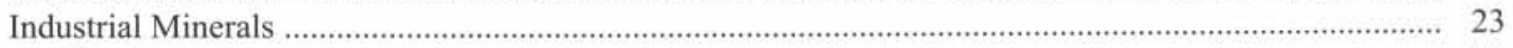

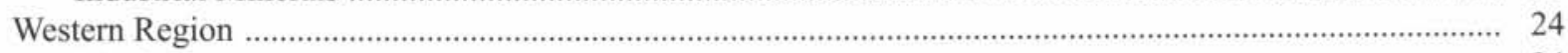

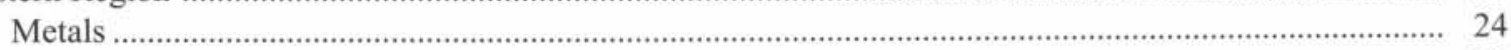

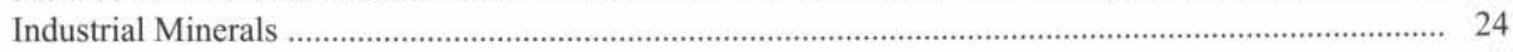

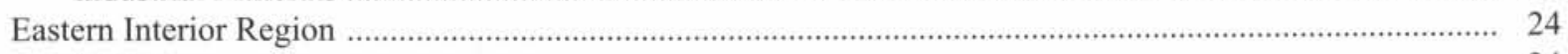

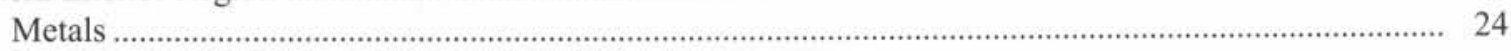

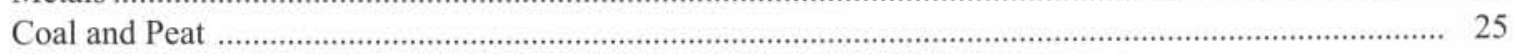

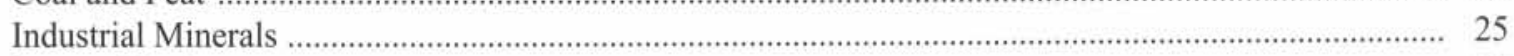

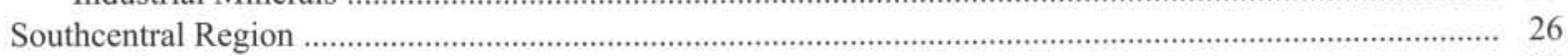

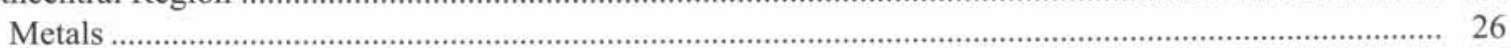

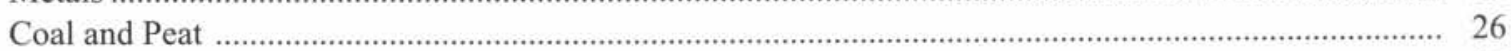

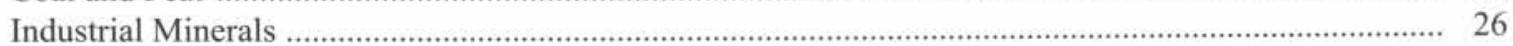


CONTENTS

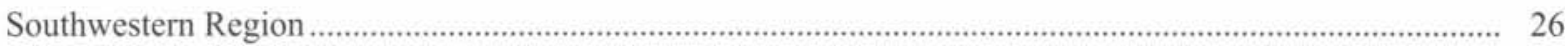

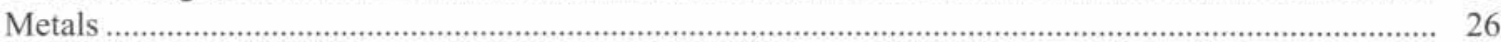

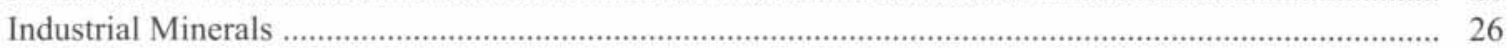

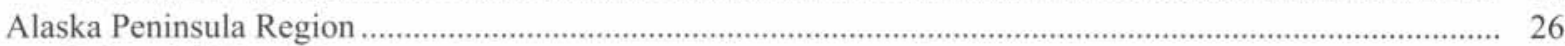

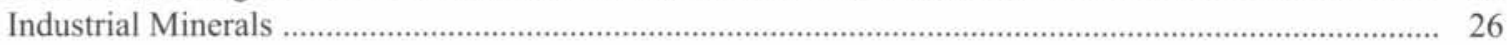

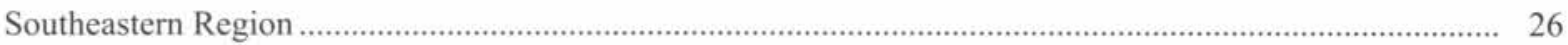

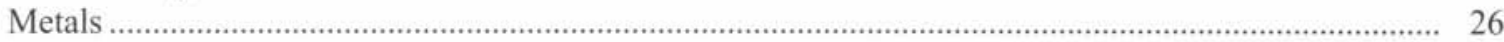

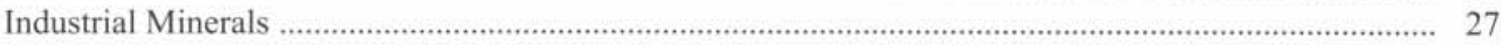

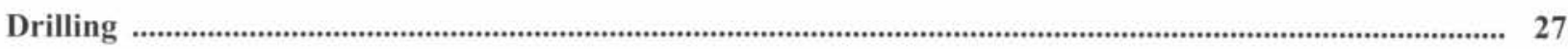

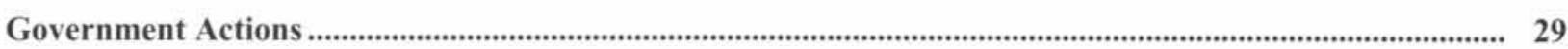

Appendixes

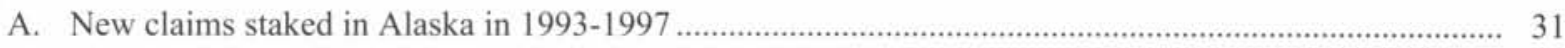

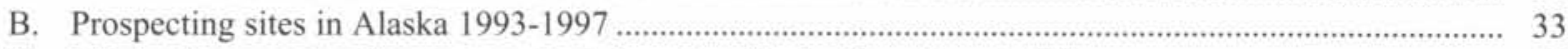

C. Mining licenses issed by and received from the Alaska Department of Revenue ................................... 35

D. Selected significant mineral deposits and mineral districts in Alaska ….............................................. 45

E. State and federal agencies and private interest groups involved in mineral
development activities .......................................................................................................... 55

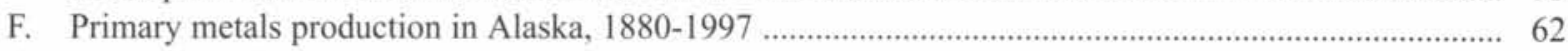

G. Production of industrial minerals, coal, and other commodities in Alaska, 1880-1997 ....................... 64

U.S. customary units and metric units conversion chart

Inside back cover

Figures

1. Graph showing comparison between the exploration and development expenditures

and the value of production of Alaska mineral industry 1981-97 .......................................................

2. Chart showing 1997 mineral industry employment by category ............................................................ 3

3. Map showing regions of mineral activity in Alaska as described in this report ....................................... 4

4. Chart illustrating exploration expenditures by commodity ................................................................. 5

5. Map showing selected mineral exploration projects in Alaska, 1997 ....................................................... 6

6. Photo of the DC North horizon of Red Mountain .............................................................................. 10

7. Photo of Jules Tileston and Bruce Campbell at the Ross-Adams uranium mine, Bokan Mountain ......... 12

8. Map showing selected mineral development projects in Alaska, 1997 ................................................ 14

9. Photos of stages in the development of the new zinc concentrate storage building at the Red Dog port site.

10. Graph showing sand and gravel production in Alaska, 1950-97 ........................................................ 20

11. Graph showing amount and value of gold production in Alaska 1880-1997 ......................................... 20

12. Graph showing coal production in Alaska 1915-97 ......................................................................... 20

13. Map showing selected production projects, 1997 ........................................................................ 21

14. Graph showing ore and metal contents of concentrate shipped from Red Dog Mine .............................. 24

15. Photo of Alaska Gold Company winter pit, Airport block \#1 ............................................................ 24

16. Photo of Roger Tallini's 8" suction dredge operation, 1997, South Fork Fortymile River ..................... 25

17. Photo showing load-out conveyor for the Greens Creek Mine at Hawk Inlet ......................................... 26

18. Photo of drilling at Alaska Gold Co.'s Submarine Pit ....................................................................... 28

19. Photo of Tom Bundtzen receiving an award for 25 years of service .................................................... 30

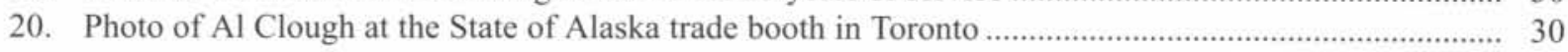

Tables

1. Total value of the mineral industry in Alaska by year (in millions of dollars) .......................................

2. Estimated Alaska mine employment, 1991-97 …….............................................................................. 2

3. Reported exploration expenditures and employment in Alaska, 1997 ................................................. 4

4. Reported exploration expenditures in Alaska by commodity, 1982-97 ................................................. 5 


\section{CONTENTS}

5. Summary of claim activity, 1990-97 ………...............................................................................

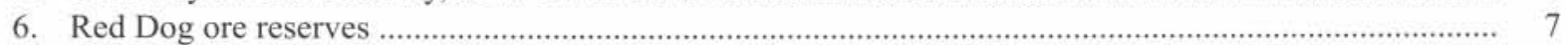

7. Reported mineral development expenditures and employment in Alaska by commodity and region, 1997

8. Reported mineral development expenditures in Alaska by commodity, 1982-97 _................................ 14

9. Estimated mineral production in Alaska, 1995-97 ..................................................................... 17

10. Companies and individuals reported to be producing metal in Alaska in 1997 ................................... 17

11. Reported refined gold production, number of operators, and industry employment, 1995-97 .............. 21

12. Production costs for selected Alaska placer gold mines, 1991-97 …….............................................. 22

13. Reported sand and gravel production and industry employment in Alaska by region, 1997 ................. 22

14. Reported stone production and industry employment in Alaska by region, 1997 ................................ 23

15. Cominco Alaska's Red Dog Mine, production statistics, 1990-97 …................................................ 23

16. Companies reporting significant drilling programs in Alaska in 1997 .............................................. 27

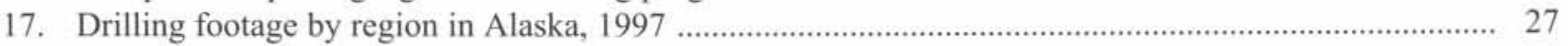

18. Drilling footage reported in Alaska, 1982-97 ............................................................................... 28

19. Revenues paid to the State of Alaska and municipalities by Alaska's mineral industry, 1992-97 .......... 29 



\section{Alaska's Mineral Industry 1997}

R.C. Swainbank, ${ }^{1}$ K.H. Clautice, ${ }^{2}$ and J.L. Nauman ${ }^{3}$

INTRODUCTION

This report summarizes Alaska's mineral activity during the 1997 calendar year and is made possible by information provided by individuals, companies, and government agencies in response to questionnaires mailed by the Division of Geological \& Geophysical Surveys (DGGS) in the Department of Natural Resources (DNR). It is a cooperative venture between DGGS and the Division of Trade and Development (DTD) in the Department of Commerce \& Economic Development (DCED), with the assistance of the DNR Division of Mining \& Water Management (DMWM).

The cumulative value of mineral production, exploration investment, and development expenditures in 1997 was $\$ 1.16$ billion (table 1; fig. 1), a slight advance over the $\$ 1.03$ billion total in 1996 .

Exploration increased a healthy 30 percent over the 1996 value to $\$ 57.8$ million, a level not seen since 1990. Although 1997 development expenditures of $\$ 168.4$ million were only 43 percent of the 1996 value, production from the mines under development or expansion in 1996 resulted in a 1997 value of $\$ 936.2$ million, an increase of 59 percent over the previous year, more than offsetting the decreased development investment.
Table 1. Total value of the mineral industry in Alaska by year (in millions of dollars)

\begin{tabular}{lrrrrr}
\hline & $\begin{array}{c}\text { Exploration } \\
\text { (expenditure) }\end{array}$ & $\begin{array}{c}\text { Development } \\
\text { (expenditure) }\end{array}$ & $\begin{array}{c}\text { Production } \\
\text { (value) }\end{array}$ & Total \\
1981 & $\$ 76.0$ & $\$ 26.4$ & $\$ 188.6$ & $\mathbf{\$ 2 9 1 . 0}$ \\
1982 & 45.0 & 41.6 & 196.4 & $\mathbf{2 8 3 . 0}$ \\
1983 & 34.1 & 27.8 & 232.4 & $\mathbf{2 9 4 . 3}$ \\
1984 & 22.8 & 53.6 & 199.4 & $\mathbf{2 7 5 . 8}$ \\
1985 & 9.2 & 34.1 & 226.6 & $\mathbf{2 6 9 . 9}$ \\
1986 & 8.9 & 24.3 & 198.5 & $\mathbf{2 3 1 . 7}$ \\
1987 & 15.7 & 100.3 & 202.4 & $\mathbf{3 1 8 . 4}$ \\
1988 & 45.5 & 275.0 & 232.2 & $\mathbf{5 5 2 . 7}$ \\
1989 & 47.8 & 134.3 & 277.0 & $\mathbf{4 5 9 . 1}$ \\
1990 & 63.3 & 14.3 & 533.0 & $\mathbf{6 1 0 . 6}$ \\
1991 & 39.9 & 25.6 & 546.5 & $\mathbf{6 1 2 . 0}$ \\
1992 & 30.2 & 30.0 & 560.8 & $\mathbf{6 2 1 . 0}$ \\
1993 & 30.3 & 27.7 & 448.7 & $\mathbf{5 0 6 . 7}$ \\
1994 & 31.1 & 44.9 & 507.5 & $\mathbf{5 8 3 . 5}$ \\
1995 & 34.3 & 148.6 & 537.2 & $\mathbf{7 2 0 . 1}$ \\
1996 & 44.6 & 394.0 & 590.4 & $\mathbf{1 , 0 2 9 . 0}$ \\
1997 & 57.8 & 168.4 & 936.2 & $\mathbf{1 , 1 6 2 . 4}$ \\
& & & & \\
TOTAL & $\$ \mathbf{\$ 6 3 6 . 5}$ & $\mathbf{\$ 1 , 5 7 0 . 9}$ & $\mathbf{\$ 6 , 6 1 3 . 8}$ & $\mathbf{\$ 8 , 8 2 1 . 2}$ \\
\hline
\end{tabular}

SOURCE: Alaska's mineral industry reports published annually by DGGS.
Figure 1. Alaska's mineral industry total value, 1981-97.

\footnotetext{
${ }^{1}$ Alaska Division of Trade and Development, 751 Old Richardson Hwy., Suite 205, Fairbanks, Alaska 99701-4948.

${ }^{2}$ Alaska Division of Geological \& Geophysical Surveys, 794 University Avenue, Suite 200, Fairbanks, Alaska 99709-3645.

${ }^{3}$ Alaska Division of Trade \& Development, 9th Floor, State Office Bldg., Juneau. Alaska 99811.
}

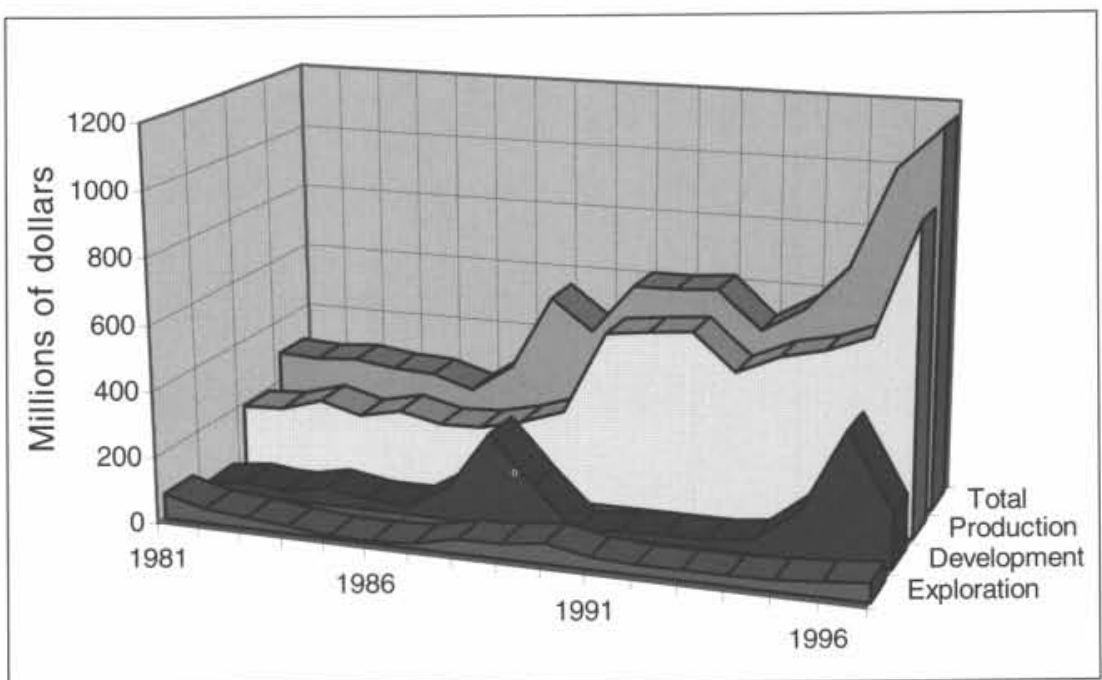


Exploration highlights in 1997 include continued success at gold prospects such as True North, Ester Dome, and Golden Summit near Fairbanks, Donlin Creek and Golden Horn near Flat, and Pogo near Delta. Substantial base metal and polymetallic exploration was reported at Red Dog and in the Ambler district near Kotzebue, throughout the eastern interior region, at the Pebble Copper prospect near Iliamna, and at the Niblack Mine on Prince of Wales Island.

Development was reported at Red Dog, Fort Knox, the Kensington gold mine near Juneau, and the Calder Bay limestone deposit on Prince of Wales Island.

Two new hardrock gold mines began production in 1997. Fort Knox, near Fairbanks, began commercial production in March, and the Illinois Creek Mine near Galena poured the first commercial gold in September. During 1997 the Greens Creek polymetallic mine reached full production, the Red Dog zinc-lead mine increased production, and the Nixon Fork gold-copper mine near McGrath maintained production. Placer gold was mined in Nome by Alaska Gold Co., in the Fairbanks area by Cripple Creek joint venture and by Polar Mining, and throughout the state by dozens of smaller operations. Usibelli Coal Mine near Healy was again the only operational coal mine in the state.

Note that there is a vague line between exploration and development, and we rely on the companies to make that distinction. The value of production is calculated using the average spot price of the metal on the London Metal Exchange multiplied by the quantity of the metals produced, as reported by companies. It does not take into account items such as smelter charges and penalties, or shipping costs. Forward sales at higher than spot prices are used if reported by a company.

\section{EMPLOYMENT}

Table 2 and figure 2 show the reported employment in the mineral industry in Alaska in 1997.

The total of 3,862 jobs represents a 3 percent increase over the previous year and is considered to be conservative because many of the questionnaires were not returned. The decrease in development jobs was due to the Fort Knox and Illinois Creek mines becoming operational, and this is reflected in the increase in lode gold employment. There was also an increase in employment in all hardrock mines in 1997 due to the increased production at Red Dog and Greens Creek, and the commissioning of the Fort Knox and Illinois Creek mines.

Employment in coal mining and in rock production was essentially the same as in 1996, but due to extensive road building, particularly in the southcentral and southeastern regions of the state, there was a substantial increase in employment in sand and gravel production in 1997.

\section{EXPLORATION}

Reported exploration expenditures statewide in 1997 were $\$ 57.8$ million, up 30 percent from the $\$ 44.6$ million invested in 1996. Over half of the activity was in the

Table 2. Estimated Alaska mine employment, 1991-97 ${ }^{a}$

\begin{tabular}{|c|c|c|c|c|c|c|c|}
\hline & 1991 & 1992 & 1993 & 1994 & 1995 & 1996 & 1997 \\
\hline \multicolumn{8}{|l|}{ Gold/silver mining } \\
\hline Placer & 1,240 & 1,251 & 1,205 & 1,150 & 975 & 825 & 780 \\
\hline Lode & N/A & N/A & N/A & -. & 38 & 138 & 415 \\
\hline Polymetallic & $35^{b}$ & $240^{\mathrm{b}}$ & 26 & -. & .. & 68 & 230 \\
\hline Base metals & 331 & 349 & 376 & 311 & 397 & 407 & 478 \\
\hline Recreational & 320 & 325 & 270 & 280 & 255 & 260 & 270 \\
\hline Sand \& gravel & 685 & 640 & 580 & 640 & 577 & 598 & 700 \\
\hline Building stone & 165 & 145 & 205 & 210 & 200 & 149 & 123 \\
\hline Coal & 115 & 115 & 109 & 115 & 120 & 115 & 118 \\
\hline Peat & 45 & 40 & 49 & 55 & 30 & 38 & 42 \\
\hline \multicolumn{8}{|l|}{ Tin, jade, soapstone, } \\
\hline Mineral development & 133 & 164 & 132 & 115 & 637 & 862 & 409 \\
\hline Mineral exploration & 268 & 137 & 164 & 182 & 157 & 257 & 277 \\
\hline TOTAL & 3,362 & 3,426 & 3,136 & 3,083 & 3,406 & 3,737 & 3,862 \\
\hline 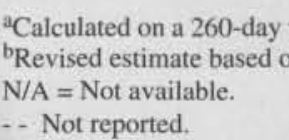 & $\begin{array}{l}\text { ear. } \\
\text { compan }\end{array}$ & & & & & & \\
\hline
\end{tabular}


eastern interior region, followed by the southwestern and southeastern regions. Precious metals were the most sought after targets, closely followed by polymetallic projects. Highlights include: a doubling of the reserves at the Paalaaq deposit at Red Dog; doubling of the resource at Pebble Copper near Iliamna to almost 11 million ounces of gold and 6 billion pounds of copper; increasing the gold resource of Donlin Creek to 6.7 million ounces; and the definition of a 4.5-million-ounce geologic reserve at the Pogo gold deposit near Delta.

\section{DEVELOPMENT}

Development investment of \$168.4 million in 1997 was less than half of the $\$ 394.0$ million in 1996 , and was predominantly at the Red Dog Mine and port site associated with the production rate increase project due to be phased in beginning in 1998. Smaller development projects were reported at most of the active mines in the state, including Illinois Creek, Nixon Fork, Usibelli Coal, Fort Knox, Greens Creek, Kensington, and dozens of placer gold mines.
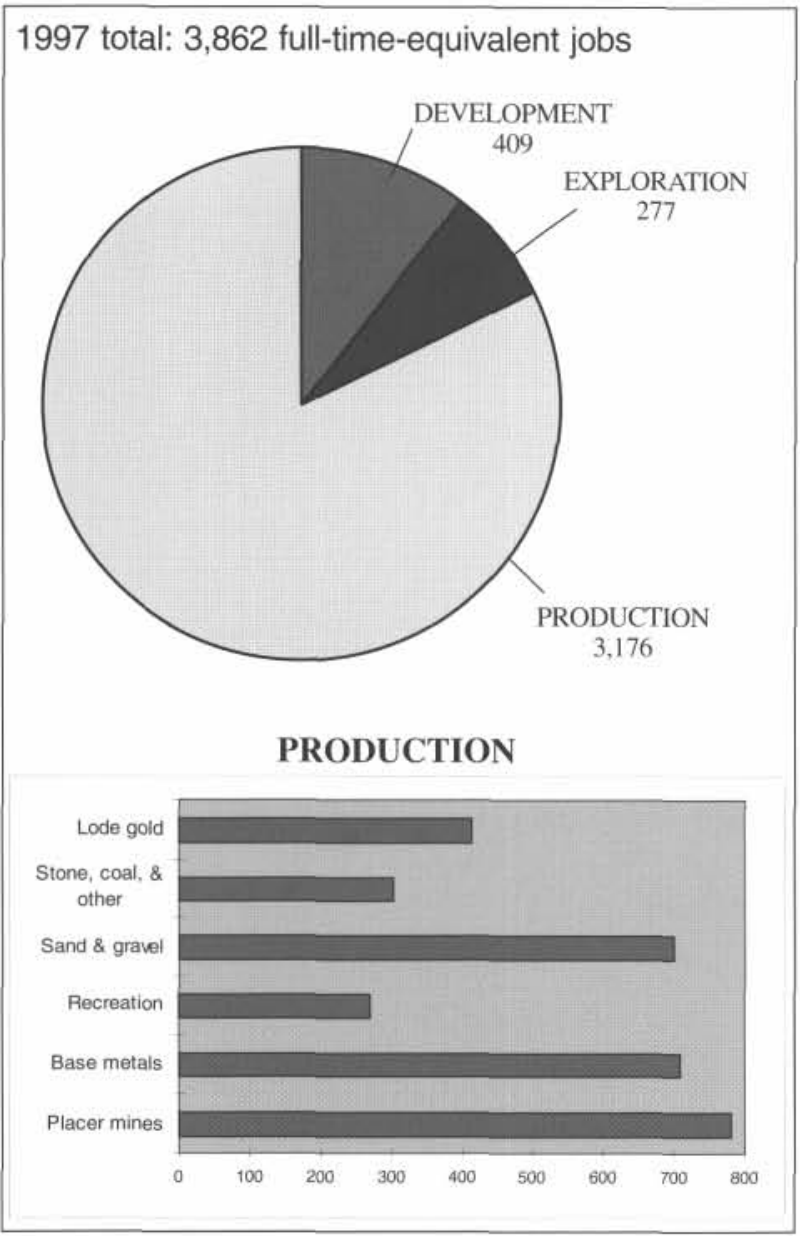

Figure 2. 1997 mineral industry employment by category.

\section{PRODUCTION}

The reported gross value of Alaska's mineral products in 1997 was $\$ 936.2$ million, up 59 percent from the $\$ 590.4$ million reported in 1996. Increased efficiency of metal recovery at Red Dog, and a higher price for the zinc product translated to a $\$ 102$ million operating profit for Cominco, up from $\$ 25$ million in 1996. The Greens Creek Mine achieved targeted production levels, as did the Nixon Fork Mine. Although plagued by lack of water, the Illinois Creek gold-silver mine managed to reach commercial production by September, and the new Fort Knox mine added a little over 1,000 ounces of gold per day to the state's production.

\section{GOVERNMENT ACTIONS}

Four government-sponsored airborne geophysical surveys were completed in 1997. DGGS contracted for one in the Talkeetna Mountains and one in the RubyPoorman area, and the U.S. Bureau of Land Management (BLM) contracted for a survey of the Wiseman area in the Brooks Range, and together with the City of Wrangell surveyed the islands around that community. These detailed surveys are thought to be the first in the nation funded by a federal agency.

In a cooperative venture, the U.S. Geological Survey and the DNR Division of Mining and Water Management began an intensive water-quality baseline study of the whole drainage basin of the Fortymile River. It is hoped that the results will provide factual data for future policy decisions.

Several mines received awards for superlative reclamation, including Cambior Alaska's Valdez Creek Mine, which won the prestigious national "Health of the Land Award" from BLM.

The Mental Health Lands Trust issue was finally settled in 1997 when an appeal by some plaintiffs to the State Supreme Court was denied.

\section{ACKNOWLEDGMENTS}

The authors wish to thank all the companies, agencies, and individuals who responded to the questionnaires. Without your voluntary and timely information this report would not be possible.

Joni Robinson of DGGS mailed 1,092 questionnaires in November 1997, and received 194 replies. Dick Swainbank, with the help of Karen Clautice, Jan Nauman, and Mitch Henning, prepared the body of the text and appendixes. The cover design is by Ann-Lillian Schell and graphic illustrations are by Alfred Sturmann, Joni Robinson, and Gail Davidson. Paula Davis edited the final version, and Joni Robinson completed the layout and design. Publication was made possible by funds from the Division of Trade \& Development. 
Figure 3 shows the regions of the state described in this and subsequent sections.

Statewide exploration expenditures reported in 1997 were $\$ 57.8$ million, up 30 percent from the $\$ 44.6$ million spent in 1996. Tables 3 and 4 show the regional distribution and the commodities sought, and figure 4 is a graphic from table 4 . Gold continues to be the most favored metal, but in recent years polymetallic deposits which contain gold and silver in addition to base metals such as copper, lead, and zinc, have become more popular. Figure 5 shows the location of the more significant exploration projects.

Table 5 is a summary of mining claim activity during the last 8 years. Slightly fewer state mining claims and slightly more federal mining claims were staked in 1997 than in 1996, but the number of active claims, both federal and state, increased in 1997.

Most of the increase in federal mining claims was in the eastern Alaska Range and in the vicinity of the city of Wrangell, where BLM and the City sponsored an airborne geophysical survey in 1997.

Other areas of the state where large numbers of claims were staked include the Ambler-Survey Pass area of the Brooks Range (Kennecott), Pebble Copper near Iliamna and near Ruby (Cominco), Pogo near Delta Junction (WGM), and in the vicinity of Paxson in the central Alaska Range.

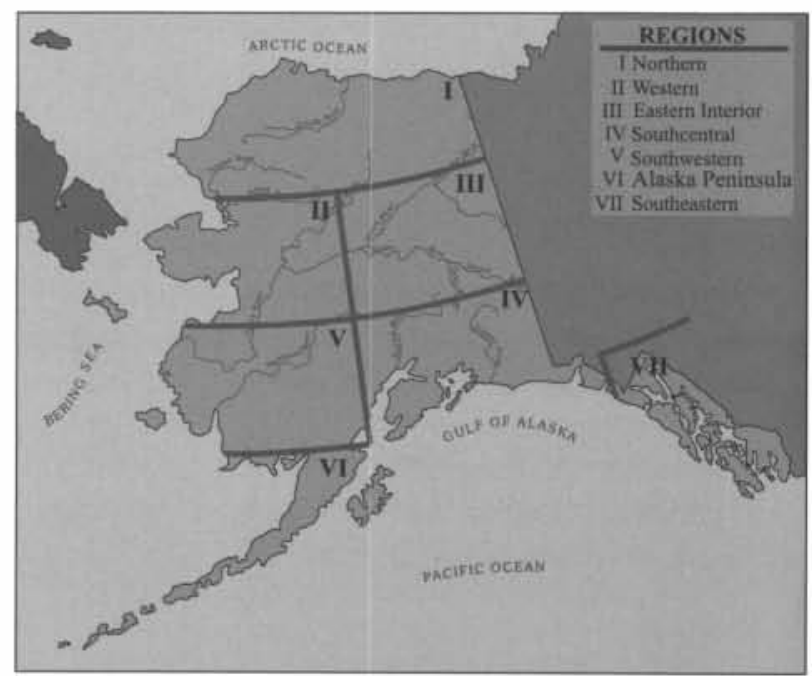

Figure 3. Regions of mineral activity in Alaska as described in this report.

Table 3. Reported exploration expenditures and employment in Alaska, 1997

\begin{tabular}{|c|c|c|c|c|c|c|c|c|}
\hline \multirow[b]{3}{*}{ Base metals } & \multirow[t]{2}{*}{ Northern } & \multirow[t]{2}{*}{ Western } & \multirow{2}{*}{$\begin{array}{c}\begin{array}{c}\text { Eastern } \\
\text { interior }\end{array} \\
\text { Exploration }\end{array}$} & \multirow[t]{2}{*}{$\begin{array}{l}\text { South- } \\
\text { central }\end{array}$} & \multirow[t]{2}{*}{$\begin{array}{l}\text { South- } \\
\text { western }\end{array}$} & $\begin{array}{c}\text { Alaska } \\
\text { Peninsula }\end{array}$ & \multirow[t]{2}{*}{$\begin{array}{l}\text { South- } \\
\text { eastern }\end{array}$} & \multirow[t]{2}{*}{ Total } \\
\hline & & & & & & & & \\
\hline & $\$ 1,700,000$ & $\$ \quad \ldots$ & $\$ \quad \cdots$ & $\$ \quad \ldots$ & $\$ \quad \ldots$ & $\cdots$ & $\$ \quad \cdots$ & $\$ 1,700,000$ \\
\hline Polymetallic & $1,525,000$ & 147,000 & $10,062,000$ & 73,000 & $2,200,000$ & $\cdots$ & $8,340,000$ & $22,347,000$ \\
\hline \multicolumn{9}{|l|}{ Precious metals } \\
\hline Placer & 210,000 & 215,000 & 366,000 & 37,000 & 296,000 & $\cdots$ & 126,000 & $1,250,000$ \\
\hline Lode & . & $2,635,000$ & $19,659,500$ & 255,000 & $8,801,000$ & - & 360,000 & $31,710,500$ \\
\hline Coal and peat & $\cdots$ & $\ldots$ & 200,000 & 520,000 & - & . & . & 720,000 \\
\hline Industrial minerals & 15,000 & - & 10,000 & 30,000 & $\cdots$ & 25,000 & $\cdots$ & 80,000 \\
\hline Other $^{\mathrm{a}}$ & .. & -. & $\ldots$ & .. & -. & $\ldots$ & - & .. \\
\hline \multirow[t]{2}{*}{ TOTAL } & $\$ 3,450,000$ & $\$ 2,997,000$ & $\$ 30,297,500$ & \multicolumn{2}{|c|}{$\$ 915,000 \$ 11,297,000$} & $\$ 25,000$ & $\$ 8,826,000$ & $\$ \mathbf{5 7 , 8 0 7 , 5 0 0}$ \\
\hline & & & \multicolumn{3}{|c|}{ Exploration employment } & & & \\
\hline \multicolumn{9}{|l|}{ Employment } \\
\hline Workdays & 7,410 & 4,227 & 36,170 & 1,177 & 14,768 & 30 & 8,268 & 72,050 \\
\hline Workyears $^{\mathrm{b}}$ & 29 & 16 & 136 & 5 & 57 & 0 & 34 & 277 \\
\hline \multicolumn{9}{|c|}{ Number of companies } \\
\hline reporting $\mathrm{c}^{\mathrm{c}}$ & 7 & 18 & 61 & 15 & 10 & 1 & 11 & 123 \\
\hline $\begin{array}{l}\text { - Not reported. } \\
\text { aJade, platinum, gemst } \\
\text { bBased on 260-day wo }\end{array}$ & $\begin{array}{l}\text { stones. } \\
\text { orkyear. }\end{array}$ & & & & & & & \\
\hline
\end{tabular}


Exploration highlights in 1997 were the expansion of reserves at the deep Paalaaq deposit near Red Dog, definition of a 4.5 million ounce gold resource at Pogo, doubling of the resource at Pebble Copper to about 11 million ounces of gold, almost doubling the resource at Donlin Creek to 6.7 million ounces of gold, and the addition of about 450,000 ounces to the gold reserve at Fort Knox.

\section{NORTHERN REGION}

Exploration expenditures reported in this region in 1997 were $\$ 3.45$ million, as compared with $\$ 1.25$ million in 1996.

\section{Metals}

At the Red Dog Mine near Kotzebue about 29,300 feet of exploration drilling continued on the new Paalaaq massive sulfide deposit discovered in 1996 at depths of 400 to 1,200 feet below surface. The new base-metal orebody is 100 to 200 feet thick, with some thicker sections over an area of 600 by 3,300 feet, and is open in all directions, with the north and west being the most favorable areas for increased reserves. This orebody has been named
Paalaaq, after a distinguished Native elder. Table 6 shows the reserves as of December 31, 1997. These new reserves make the Red Dog the largest zinc orebody ever known in the world.

Farther east, NANA and Kennecott drilled about 5,000 feet on the Bornite Mississippi Valley-type copper deposit, and following the airborne surveys of 1996 Kennecott staked a very large group of claims in the Ambler-Survey Pass area. The company also continued exploration in the Ambler copper belt, which contains its Arctic Kuroko-type deposit (see Appendix D, number 9).

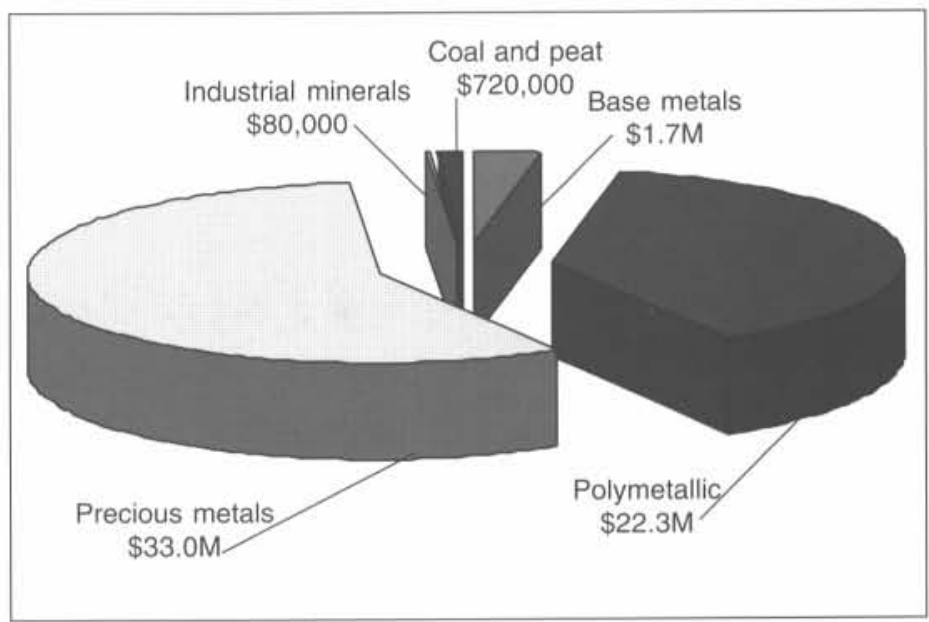

Figure 4. 1997 exploration expenditures by commodity.

Table 4. Reported exploration expenditures in Alaska by commodity, 1982-97

\begin{tabular}{|c|c|c|c|c|c|c|c|}
\hline & $\begin{array}{c}\text { Base } \\
\text { metals }\end{array}$ & Polymetallic ${ }^{a}$ & $\begin{array}{c}\text { Precious } \\
\text { metals }\end{array}$ & $\begin{array}{c}\text { Industrial } \\
\text { minerals }\end{array}$ & $\begin{array}{c}\text { Coal } \\
\text { and peat }\end{array}$ & Other & Total \\
\hline 1982 & $\$ 31,757,900$ & N/A & \$ $10,944,100$ & $\ldots$ & \$ $2,900,000$ & 15,300 & $\$ 45,617,300$ \\
\hline 1983 & $9,758,760$ & N/A & $20,897,555$ & $2,068,300$ & $1,338,454$ & 70,000 & $34,133,069$ \\
\hline 1984 & $4,720,596$ & N/A & $14,948,554$ & 270,000 & $2,065,000$ & 279,500 & $22,283,650$ \\
\hline 1985 & $2,397,600$ & N/A & $6,482,400$ & (. & 270,000 & - & $9,150,000$ \\
\hline 1986 & $1,847,660$ & N/A & $6,107,084$ & 170,000 & 790,000 & $\ldots$ & $8,914,744$ \\
\hline 1987 & $2,523,350$ & N/A & $11,743,711$ & 286,000 & $1,150,000$ & 31,000 & $15,734,061$ \\
\hline 1988 & $1,208,000$ & N/A & $41,370,600$ & 160,200 & $2,730,000$ & .. & $45,468,800$ \\
\hline 1989 & $3,503,000$ & N/A & $43,205,300$ & 125,000 & 924,296 & 5,000 & $47,762,596$ \\
\hline 1990 & $5,282,200$ & N/A & $57,185,394$ & 370,000 & 321,000 & 97,000 & $63,255,594$ \\
\hline 1991 & $4,789,500$ & N/A & $34,422,039$ & 92,000 & 603,000 & 2,000 & $39,908,539$ \\
\hline 1992 & $1,116,000$ & $3,560,000$ & $25,083,000$ & 25,000 & 425,000 & .. & $30,209,000$ \\
\hline 1993 & 910,000 & $5,676,743$ & $23,382,246$ & 163,500 & -. & 125,000 & $30,257,489$ \\
\hline 1994 & 600,000 & $8,099,054$ & $18,815,560$ & 225,000 & $2,554,000$ & 810,000 & $31,103,614$ \\
\hline 1995 & $2,770,000$ & $10,550,000$ & $20,883,100$ & 100,000 & . & 3,000 & $34,306,100$ \\
\hline 1996 & $1,100,000$ & $11,983,364$ & $31,238,600$ & 400,000 & . & -. & $44,721,964$ \\
\hline 1997 & $1,700,000$ & $22,347,000$ & $32,960,500$ & 80,000 & 720,000 & -. & $57,807,500$ \\
\hline TOTAL & $\$ 75,984,566$ & $\$ 62,216,161$ & $\$ 399,669,743$ & $\$ 4,535,000$ & $\$ 16,790,750$ & $\$ 1,437,800$ & $\$ 560,634,020$ \\
\hline
\end{tabular}

aPolymetallic deposits considered as a separate category for the first time in 1992.

$\mathrm{N} / \mathrm{A}=$ Not available. 


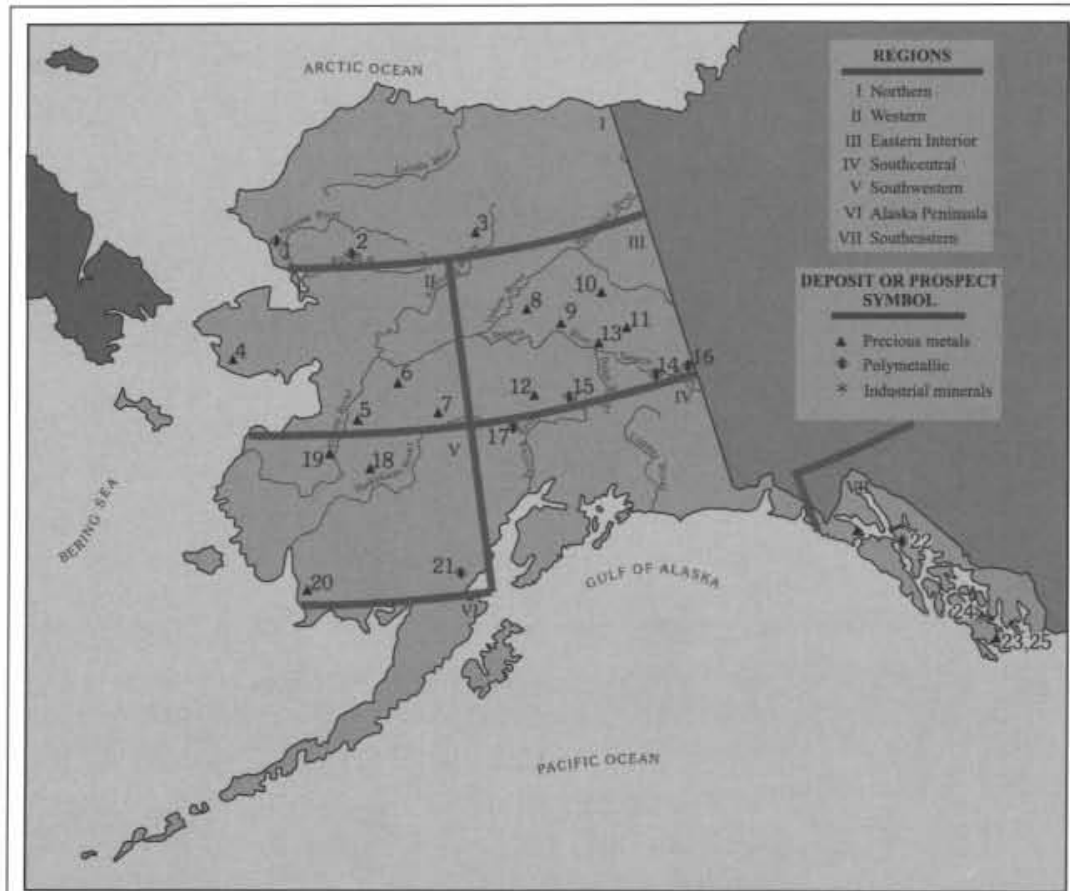

I Northern Region

1. Red Dog Mine-Cominco Alaska Inc.

2. Ambler mineral beltKennecott Exploration Co.

3. Wiseman area-Ventures Resource Alaska Corp.

\section{Western Region}

4. Nome area-Kennecott Exploration Co., Cominco Alaska Inc., Altar Resources

5. Illinois Creek-Dakota Mining Corp.

6. Ruby area-Cominco Alaska Inc., Placer Dome U.S. Inc.

7. Nixon Fork-Consolidated Nevada Goldfields Corp.

III Eastern Interior Region

8. Sawtooth MountainASA Inc./Montague J-V

9. Fairbanks district

a. True North-Newmont Exploration Ltd.

b. Fort Knox-Fairbanks Gold Mining Inc.

c. Ester Dome-Silverado Gold Mines Ltd.

d. General-Amax Gold Exploration, Placer Dome U.S. Inc.

e. Golden Summit-International Freegold Inc.

10. Circle district-LaTeko Resources

11. Pogo-Teck Corp./Sumitomo Metal Mining Canada Ltd.
12. Bonnifield district-Liberty Bell Mining, Grayd Resource Corp.

13. Richardson districtKennecott, Cyprus-Amax, Golden Phoenix Minerals Inc. Tri-Valley Corp.

14. Tok area-American Copper \& Nickel Co. Inc. (ACNC)

15. Nikolai-ACNC/Fort Knox Gold Resources Inc. (FNGRI)

16. Taurus-Cross Canada International Resources

IV Southcentral Region

17. Upper Chulitna areaAddwest Minerals Inc., Kennecott Exploration Co.

\section{Southwestern Region}

18. Donlin Creek-Placer Dome U.S. Inc., Cominco Alaska Inc., Ventures Resource Alaska Corp.

19. Stuyahok - Calista Corp.

20. Goodnews Bay-Corral Creek Corp.

21. Pebble Copper-Cominco Alaska Inc.

VI Alaska Peninsula Region

VII Southeastern Region

22. Greens Creek-Kennecott Greens Creek Mining Co.

23. Dolomi-Sealaska Corp.

24. Calder Bay-Sealaska Corp.

25. Niblack-Abacus Minerals Inc./Teck Corp.
At the eastern end of the southern Brooks Range near Wiseman, Silverado Gold Mines continued exploration for the lode source of the large nuggets found in its Nolan Creek placer gold mine. Gold Dust Mines reported some exploratory drilling in the Chandalar Lake area, and Steve Greene explored in the Koyukuk drainage, but was plagued by the lack of water.

Ventures Resource Alaska found good copper values ( 3 plus percent) over substantial widths ( 20 to 30 feet) on the Luna deposit and on the Venus skarn prospect northeast of Wiseman. The Luna also contains zinc, cobalt, silver, and gold, while the Venus contains silver and gold. These prospects are on lands controlled by Doyon Ltd.

In an unusual arrangement, BLM contracted with On-Line Exploration and Sial Geosciences to conduct an airborne geophysical survey of the Chandalar copper belt northeast of Wiseman. The survey area contains the Venus and Luna prospects and the Nolan area west of the haul road. The program was managed by DGGS to conform to the standards set in almost a dozen surveys elsewhere in the state.

\section{Industrial Minerals}

The NANA Corp. explored for sand and gravel resources near some of the villages in the region, but there was no exploration for coal in the northern region in 1997.

\section{WESTERN REGION}

Exploration expenditures reported in this region in 1997 were $\$ 3.0$ million, down from $\$ 3.8$ million the previous year, primarily due to reduced exploration on lands north of Nome.

\section{Metals}

Cominco continued exploration in the Aurora trend north-west of Nome both on land owned by the Bering Straits Native Corp. and on

Figure 5. Selected exploration projects in Alaska, 1997. 
Table 5. Summary of claim activity, 1990-97

\begin{tabular}{|c|c|c|c|c|c|c|c|c|}
\hline Year & 1990 & 1991 & 1992 & 1993 & 1994 & 1995 & 1996 & 1997 \\
\hline \multicolumn{9}{|l|}{ New claims } \\
\hline State & 2,573 & 3,391 & 2,606 & 2,042 & 3,365 & 4,889 & 10,716 & $10,002^{\mathrm{a}}$ \\
\hline Federal & 1,888 & 1,299 & 695 & 601 & 341 & 376 & 1,571 & 1,872 \\
\hline Subtotal & 4,461 & 4,690 & 3,301 & 2,643 & 3,706 & 5,265 & 12,287 & 11,874 \\
\hline \multicolumn{9}{|c|}{ Active claim assessment } \\
\hline State & 32,275 & 29,754 & 26,615 & 25,684 & 22,601 & 20,217 & 25,586 & 27,602 \\
\hline Federal & 25,792 & 23,222 & 20,254 & 9,298 & 8,495 & 7,766 & 9,346 & 11,320 \\
\hline Subtotal & 58,067 & 52,976 & 46,869 & 34,982 & 31,096 & 27,983 & 34,932 & 38,922 \\
\hline Total state & 34,848 & 33,145 & 29,221 & 27,726 & 25,966 & 25,106 & 36,302 & 37,604 \\
\hline Total federal & 27,680 & 24,521 & 20,949 & 9,899 & 8,836 & 8,142 & 10,917 & 13,192 \\
\hline TOTAL & 62,528 & 57,666 & 50,170 & 37,625 & 34,802 & 33,248 & 47,219 & 50,796 \\
\hline
\end{tabular}

an addition, 2,239 new prospecting sites, equivalent in area to 8,956 mining claims, were located in 1997. Includes 3,969 new claims on Stateselected land.

Information provided by Ronna Graham (Division of Mining \& Water Management) and Don Baggs (U.S. Bureau of Land Management).

claims leased from Altar Resources or owned by

Cominco. The company had a modest geophysics and drilling program in the area in 1997.

Much of the land covered by the 1993 state airborne geophysical survey is now under claim, and there was a lot of activity east of Nome, where Intercontinental Mining drilled 6,000 feet of core on the Big Hurrah Mine.

Visible gold was evident in several holes, and hole 3 cut 30 feet with a gold grade of 0.134 ounces per ton and 15 feet of 0.108 ounces per ton. Hole 5 cut 17.5 feet of 0.212 ounces per ton.

Numerous individuals are actively exploring the Seward Peninsula for placer gold, including Buckley Mining on Slate Creek, Don Harris on Moore Creek, High Bench Mining at Nekula Gulch, Lost River Mining at Tripple Creek, Dennis Nottingham in the Kougarok, Scotti Mining in Council and the Kougarok, Edwin Sears west of Nome, and Thurman Oil \& Mining on Bering Straits Native Corporation land in Dahl Creek.

Late in the year La Teko Resources Ltd. announced that it had acquired the Mt. Distin prospect north of Nome from Kennecott Exploration, but the option was allowed to lapse. Kennecott had a modest exploration program of its own at Mt. Distin.

USMX of Alaska Inc. reported minor geochemistry, geologic mapping and drilling for gold and silver near its Illinois Creek mine south of Galena. Reserves at year end, at a gold price of $\$ 330$ per ounce, stood at 1.9 million tons of 0.076 ounces of gold and 1.16 ounces of silver per ton.

\begin{tabular}{|c|c|c|c|c|}
\hline & $\begin{array}{c}\text { Tons } \\
\text { (millions) }\end{array}$ & $\begin{array}{l}\text { Zinc } \\
\text { (wt\%) }\end{array}$ & $\begin{array}{c}\text { Lead } \\
(w t \%)\end{array}$ & $\begin{array}{l}\text { Silver } \\
\text { (oz/ton) }\end{array}$ \\
\hline Main & 55.8 & 19.0 & 5.2 & 2.89 \\
\hline Aqqaluk & 80.4 & 13.6 & 3.7 & 1.90 \\
\hline Hilltop & 10.6 & 17.8 & 5.5 & 3.42 \\
\hline Paalaaq & 15.5 & 14.3 & 3.9 & 2.42 \\
\hline Total & 162.3 & 15.8 & 4.4 & 2.39 \\
\hline
\end{tabular}

${ }^{a}$ As of December 31, 1997.

Consolidated Nevada Goldfields had a substantial exploration program on its own claims and on land leased from Doyon Ltd. near the Nixon Fork Mine.

Exploration by Cominco and Placer Dome in the Central Kuskokwim Mountains and near Ruby resulted in the staking of mining claims by both companies, and Placer Dome drilling at Colorado and Ganes creeks. Corral Creek Resources Inc. also staked claims in the Ruby area. Little Creek Mine reported some exploration on 10-Pup off Little Creek.

There was exploration activity in the Melotzitna area west of Tanana by Footwall Exploration, and Ventures Resource had a trenching program west of Tanana on a coincident geochemical and geophysical anomaly.

DGGS contracted with WGM-Dighem to fly an airborne geophysical survey of the Ruby-Poorman area in 1997, with the results released in February 1998. 
No exploration for coal or industrial minerals was reported in 1997 in this region.

\section{EASTERN INTERIOR REGION}

Reported exploration in the eastern interior region was \$30.3 million in 1997, up 65 percent from 1996. Several junior mining companies were very active, acquiring land positions by staking claims and by leasing or purchasing existing prospects and properties.

\section{Metals}

Fairbanks Gold Mining Inc., operator of the Fort Knox gold mine, had a 12-hole, 5,000-foot exploratory reverse-circulation drilling program on the Gil East claims about 8 miles east of the Fort Knox Mine, where the best of six mineralized holes returned 170 feet of 0.048 ounces per ton gold.

Newmont Exploration Ltd. continued an aggressive exploration and acquisition program with La Teko Resources on the True North property about 8 miles west of the Fort Knox mine. Newmont can earn 65 percent ownership by spending $\$ 21$ million and producing a feasibility study. Mineralization at True North is associated with quartz-carbonate veins in a high-grade metamorphic package containing calcareous eclogites, particularly where carbonaceous schists and quartzite are prevalent. Northwest-trending fractures along the northeast-trending Eldorado Creek Fault seem to have offset and possibly control the higher-grade zones. Prior to this year's 55,000-foot reverse-circulation and core drill programs, and the discovery of the Merlyn and Dome Creek mineralized zones, geologic resources were calculated to be 1.3 million ounces of gold.

Placer Dome North America also had a drill program to the southwest of True North in the same type of rocks. La Teko contracted for a closely-spaced airborne geophysics program for its large Juniper Creek prospect about 15 miles northeast of the True North property, and for the adjacent Twin Buttes block that it leased from the University of Alaska. Several interesting anomalies were found in 1997 in the Twin Buttes block, and more claims were acquired.

La Teko Resources also had encouraging results, including gold-in-soil anomalies up to 0.07 ounces per ton at the Discovery Gulch prospect in the Circle district. The company also agreed to sell its Ryan Lode Mine on Ester Dome (6 miles west of Fairbanks) to Silverado Gold Mines for \$12 million. Ryan Lode has proven/probable reserves in the schist-hosted Ryan Shear and igneous-hosted Curlew deposits to 300-foot depth of 820,000 ounces of gold. The shear extends at least to the 1,100 foot depth.

Silverado drilled a total of 8,800 feet of reverse circulation holes on the Ryan Lode as part of its due- diligence review of the mineral potential in 1997, but has since relinquished its option.

Silverado also controls most of the land around La Teko's Ester Dome property, including the former producer, Grant Mine, about 2 miles northeast of Ryan Lode. Mineralization at Grant Mine in the Irishman and O'Dea veins extends to at least 1,200 feet in depth and may represent an offset continuation of the Ryan Shear deposit. Elsewhere on Ester Dome, Silverado drilled and trenched the St. Paul zone (about a mile north of, and subparallel to, the Ryan Lode), and has outlined igneous-hosted gold mineralization at the Rhyolite prospect on the northwestern side of the dome. Silverado also holds claims immediately northeast of True North at the Whiskey Gulch and Marshall Dome blocks.

Cripple Creek Joint Venture found mineralized intrusive rock in the floor of its placer operation at Ester, west of Fairbanks, and collected samples for assay.

International Freegold Mineral Development had a robust exploration program managed by Avalon Development Corp., including 10,000 feet of reversecirculation drilling and 3,600 feet of core drilling at various prospects within its 22,560 -acre landholdings of the Golden Summit project. Barrick Gold has the right to buy up to 70 percent of the project by purchase of $\$ 10$ million in Freegold stock over the next 4 years. The Golden Summit property contains several old mines (Cleary Hill, Newsboy, Tolovana, Christina, Hi-Yu) with gold grades from 0.29 ounces per ton to more than one ounce per ton. Recent drilling shows that the Cleary Hill Mine, in addition to a 100,000 -ounce resource grading 0.81 ounces per ton, has potential for bulk tonnage, lower-grade material in the footwall of the high-grade veins.

The Golden Summit property also contains the Dolphin igneous-hosted gold-bearing system west of the Cleary Hill Mine which has drill-indicated reserves of 30.6 million tons at a grade of 0.02 ounces per ton, but is still open to the east, west, and at depth. Elsewhere on the property there are numerous early- to mid-stage prospects (Charles, Northern Extension, Wolf Creek, Goose Creek, Too Much Gold, and Iowa) that are being systematically explored. Several are strategically situated relative to the eastern extension of the Eldorado Creek Fault that bounds the True North property.

Placer Dome transferred ownership of its 20,000acre holdings northeast and southwest of True North to International Freegold on November 5, 1997.

There was no activity reported at Can-Ex Resources' Eagle Creek project west of True North, but newlystaked claims to the west of Eagle Creek, including the mineralized Our Creek igneous stock, were being explored in 1997. Cyprus-Amax explored on the nearby Old Dog prospect, and drilled 2,700 feet of reverse-circulation hole, in addition to reconnaissance 
work in the Fairbanks area. Grateful Dog Mining Company reported exploration in the same general area, and also on Wilber Creek near Livengood.

At the Pogo prospect 40 miles northeast of Delta Junction, Teck Corp. started its buy-in to Sumitomo's project in June by funding the $\$ 5.5$ million, 46-hole, 47,200-foot 1997 drilling program, which was supported by five drills and a 45-person crew. Teck announced that Pogo contains a geologic reserve of almost 4.5 million ounces of gold in 10.9 million tons of rock in two 24-foot-thick, flat-lying veins, with a possible third layer below. The gold occurs as veins in almost horizontal quartzite about 400 feet below a steep-sided valley, so advanced exploration will be from underground. To date over 42 line-miles of induced polarization (IP) survey, 35 line-miles of constant source audio magneto telluric (CSAMT) survey, 10 miles of magnetic survey, 385 miles of airborne electromagnetic (AEM) survey and 83,903 feet of drilling have been completed. An ice road was constructed to transport fuel and equipment to the site of the access tunnel portal.

Tri-Valley Corp. had a 5,000-foot core and reversecirculation drill program on its large block of claims in the Richardson district about 40 miles west of Pogo, and Ventures Resource Alaska Inc. confirmed high-grade silver-lead-zinc mineralization on its Eva prospect about 50 miles to the east of Pogo.

Ventures Resource also drilled 3,000 feet of core on the north and west sides of a 3,000 by 4,000 foot geochemical anomaly at the Champion II prospect. At Lead Creek, 30 miles southwest of Eagle, Ventures drilled 3,800 feet on a coincident soil silver-lead-zinc and electromagnetic anomaly. Several holes cut 3.5 -foot-thick massive sulfide mineralization in silicified and brecciated limestones with up to 8.8 ounces of silver per ton, 14.2 percent lead and some zinc. Thicker mineralized horizons were also encountered. At the Eva prospect a vein with at least 1,800 feet of strike length assayed 28.7 percent lead, 9.4 percent zinc, 0.28 percent copper, 0.003 ounces per ton gold and 19.4 ounces of silver per ton across an 18-foot trench sample. All of these prospects are on land controlled by Doyon Ltd. In late November, Teck Corp. agreed to invest $\$ 4.1$ million in Ventures to explore the Veta block, with an option to invest $\$ 3.5$ million more to acquire 60 percent of a target of their choice within the area.

American Copper \& Nickel Company (ACNC) had a 16,000 -foot diamond drill program on its Delta project southwest of Tok, and managed its Nikolai joint venture for which Fort Knox Gold Resources Inc. provided the funds. A 7,500-foot core-drill program in the 3.5-mile strike length of the Ice prospect near Canwell Glacier cut mafic and ultramafic rocks with 17 feet of 0.78 percent nickel, 0.55 percent copper, 0.023 ounces per ton platinum, 0.026 ounces per ton palladium and 0.006 ounces per ton gold. Elsewhere in the Nikolai project a 6,566-foot six-hole drill program at the Fish Lake prospect cut 278 feet with up to 10 percent disseminated pyrrhotite, with assays ranging from 0.03 to 0.26 percent copper, 0.16 to 0.36 percent nickel, 35 to $220 \mathrm{ppb}$ platinum and 60 to $222 \mathrm{ppb}$ palladium. An 80 -foot intercept and a 190-foot intercept in two other holes cut disseminated sulfides with similar grades. At year end Grayd Resource Corp. acquired an interest in the Delta Project in addition to several other polymetallic properties through agreements with Pacific Northwest Resources Company and Pacific Alaska Resources Corp.

Several other companies were active in the Nikolai area, including Falconbridge Ltd., Tullaree Alaska Inc., and Golden Phoenix Minerals Company. The mineralization at Nikolai is hosted in Triassic(?) mafic and ultramafic plutonic and volcanic rocks cut off to the north by a strand of the Denali Fault system. The offset portion of the mafic rocks would be expected to occur near Kluane Lake.

North of Tok, Cross-Canada International had a modest program on the Taurus copper-gold porphyry.

In the Bonnifield district east of Healy, Liberty Bell Mining had a 5,000-foot core-drill program on the epithermal-type gold prospect, and Grayd Resource Corp., with the backing of Atna Resources, had a 12,900-foot core-drill program on the Red Mountain zone of the Dry Creek massive sulfide project. One hole in this 6,000-foot conductive zone cut 18 feet of 25.9 percent zinc, 11.7 percent lead, 0.88 percent copper, 10.1 ounces per ton silver, and 0.1 ounces per ton gold. Sulfides were also found 2,400 feet along strike. The WTF zone of the project may be on the north limb of a synclinal structure, with the Red Mountain zone on the south limb. Grayd also investigated a 4,000-foot electromagnetic conductor at Anderson Mountain 16 miles west of Red Mountain, and is preparing a second drill rig for the 1998 season (fig. 6).

In the Rampart-Manley area, numerous large claim groups have been staked and at least one airborne geophysical survey was conducted. ASA continued its evaluation of Doyon land in the area east of Manley, with a 1,000-foot core-drill program. Placer Dome had a core-drill program on holdings leased from Alaska Placer Development at Livengood.

There was a little activity in the Sourdough Creek area midway between Fairbanks and Circle following a major staking program in 1996.

Placer exploration was reported in the RampartManley area by Bed Rock Enterprises (Killarney Creek and Roughtop Mountain); BIFS Mining and Eleven Pup Mining (Eureka Creek), and Slate Creek Mining on Slate Creek. Alaska Placer Development drilled almost 
18,000 feet of reverse-circulation exploration holes on Livengood Bench in the Livengood district. In the Circle district placer exploration was reported by Eugene Clyne on Crooked Creek; Colledge Enterprises on Bottom Dollar Creek; Fred Cook and Points North on Portage Creek; Dan Fair on Ptarmigan Creek; Paul \& Company on Bonanza Creek; and Underwood Mining on Bonanza and Porcupine Creeks. In the Fairbanks district A.M. Mining Ltd. explored on Dome Creek, Lucky Seven Mining Co. tested the placers on Gilmore Creek, and Tillicum Resources Inc. tested at Fox. The only placer exploration reported in the Bonnifield district was drilling on 50-foot centers by D'Log Industries Inc. at an undisclosed location. The Fortymile River drainage saw a lot of placer exploration in 1997, with Adam Argo on the South Fork, Harvey Bickell on the Walker Fork, Scott Reed on the North Fork,

Geoquest on Chicken Creek, and Guy Fichtelman worked both east and west of Chicken. Paystreak Mining explored near Jack Wade, EBP mapped and sampled the Smith Bench, Chickaman Mining worked on Uhler Creek, Leo Regner explored Lilliwig and Ingle creeks, 40-Mile Mining Co. drilled on Dry Gulch near Chicken, and Camp Creek Mining explored at an undisclosed location in the Fortymile district.

\section{COAL}

Usibelli Coal Mine Inc. reported a 4,000-foot reverse-circulation exploration drill program around its leases at Poker Flats, Two Bull Ridge and Gold Run Pass.

\section{Industrial Minerals}

Globe Creek Mining Inc. had a mapping and geochemical sampling program at its limestone operation at Globe Creek midway between Fairbanks and Livengood.

\section{SOUTHCENTRAL REGION}

Investment in exploration in the southcentral region in 1997 was only $\$ 915,000$, compared to $\$ 2$ million in 1996.

\section{Metals}

There was substantial exploration activity in the area, particularly along the south flank of the Alaska Range in the Petersville-Collinsville area and in the Upper Chulitna area south of Cantwell.

In the Valdez Creek area, La Teko Resources had a trenching and sampling program at its Lucky Gulch

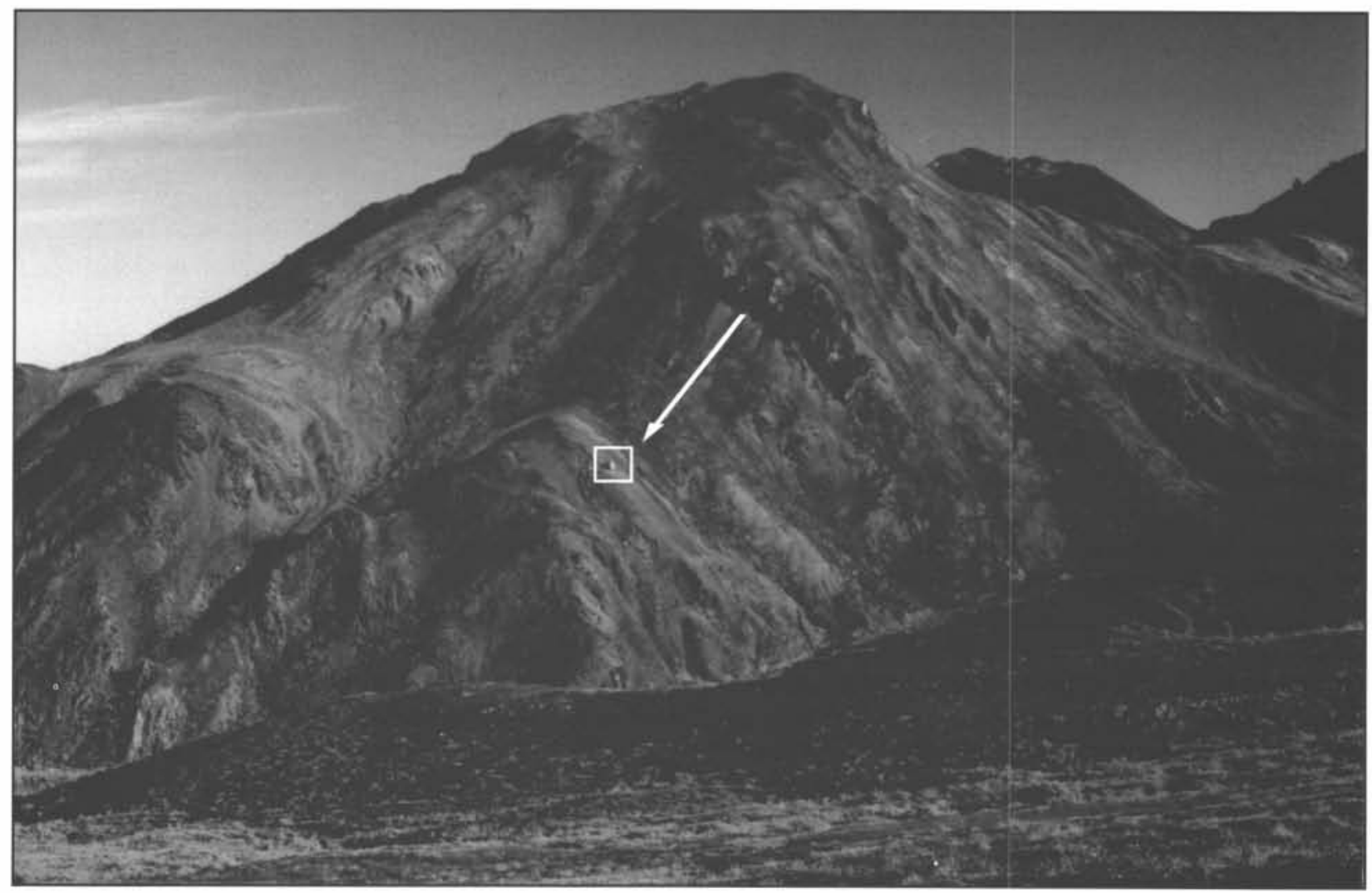

Figure 6. Dramatic view of the DC North horizon of Red Mountain. The drill rig can be seen on the structure at the center of the picture. Photo courtesy of Grayd Resources Corp. 
prospect, and discovered several anomalous areas for future follow-up. International CanAlaska Resources continued its exploration of the Rainbow Hill prospect nearby. Intercontinental Mining announced its intention to explore the Denali (Pass Creek) copper deposit, which has reserves of about 5 million tons of finegrained sulfides running about 2 percent copper.

Staking occurred in 1997 in the vicinity of the Golden Zone Mine, following the release of the results of the 1996 airborne geophysical survey. Kennecott drilled one of the more striking conductive zones, and Addwest Minerals International Inc. continued evaluation of the area around the Golden Zone Mine. DGGS began mapping the district to provide ground truth for the geophysical survey.

Numerous prospect sites were located in the Petersville-Collinsville geophysical survey area where unexpected northwest-trending features were evident in this area of predominantly northeasterly-trending geology. Diamond Gold Corporation reported exploration in the Yenlo Hills for disseminated and massive sulfides, $\mathrm{H} \& \mathrm{H}$ Exploration and Mining reported placer exploration near Collinsville, and Northern Mining explored for placer near Petersville.

Placer exploration was also reported near Nelchina (4S Services), at Willow Creek (Mrak Placer Mine), at Eureka Creek and Hatcher Pass (Jagade Perkins Jr.), and at Canyon Creek (Outsider Mining). Placer exploration was also reported on the Kenai Peninsula by Tom Sternberg (Quartz Creek), Sunrise Exploration Services, and Gerald Willard (Bear Creek near Hope). At the old Gilpatrick Mine northwest of Seward, Eric Treider reported hardrock exploration that will continue in 1998.

DGGS contracted for an airborne geophysics survey in the Iron Creek area of the Talkeetna Mountains during the summer of 1997.

\section{CoAl}

Usibelli Coal Mine Inc. purchased the rights to the Wishbone Hill Mine east of Palmer from North Pacific Mining Corp., a subsidiary of the Cook Inlet Region Inc. Native corporation. Surface mineable coal reserves at Wishbone Hill are about 14 million tons, but the geologic structure is complex. When washed, the coal has a heat content of about 12,200 BTU, as compared with 7,800 BTU for the coal at Usibelli's mine at Healy.

Slightly farther east at the Jonesville coal lease, Nerox Power Systems Inc., a subsidiary of Nerox Energy Corp., working with Sumitomo Coal Mining Co. Inc., drilled two core holes for a total of 4,541 feet into the axis of the syncline at the Evan Jones Mine, finding 44 feet of high-rank coal in two seams over a 225 -acre area, suggesting an 18- to 30-million-ton resource.

\section{SOUTHWESTERN REGION}

Exploration expenditures in the southwestern region in 1997 were $\$ 11.3$ million, about the same as in 1996.

\section{Metals}

Placer Dome's activity at Donlin Creek near Flat continued to excite interest in the Kuskokwim Mountains as a whole, and there was renewed interest in the Pebble Copper deposit near Lake Iliamna.

At Donlin Creek, about midway between Bethel and McGrath, Placer Dome had a 52,546-foot core-drill and a 26,892-foot reverse-circulation program continuing evaluation of several areas of gold-sulfide mineralization associated with 65-million-year-old granitic plutons intruded into Jurassic-Cretaceous flysch. The purpose of the program was to identify areas where oxidation of the sulfide-rich ore was deeper, thus increasing the oxide ore inventory. At year-end reserves in all categories were 6.7 million ounces of gold in 67 million tons of ore.

Ventures Resource Alaska drilled 17,128 feet of core in the Flat area; at the Golden Horn Mine another vein was discovered parallel to the former producer, and the potential for bulk-tonnage mineralization was identified. One of the first drill holes cut 27 feet with 0.3 ounces of gold per ton. A separate program at the Chicken Mountain area 5 miles to the south showed 70 feet of 0.416 ounces of gold per ton in one hole, and 6,655 feet of trenching revealed a 90 -foot zone that assays 0.193 ounces per ton. The gold-in-soil anomaly associated with these results extends over an area 12,000 by 2,000 feet. Ventures also increased the size of its holdings along the Donlin Creek trend to the northeast of Placer Dome's holdings. Western Mining Corp. (USA) had a modest exploration program in the same area.

Corral Creek Resources continued exploration for platinum at Red Mountain near Goodnews Bay on Calista Corp. lands and the Calista Corp. explored for gold and platinum in the Marshall, Stuyahok, Nyac, Kuskokwim Mountains, and Goodnews Bay areas. The Wylie Operation trenched on the Mt. Top mercury prospect.

Cominco has reportedly discovered higher grades of gold in a portion of its Pebble Copper porphyry deposit north of Lake Iliamna, and several hundred claims were staked in late 1996. Activity in 1997 included 14,600 feet of core drilling which doubled the size of the resource to more than a billion tons containing almost 11 million ounces of gold and 6 billion pounds of copper.

Placer exploration was reported at a number of placer mines. Flat Creek Mining Co. prospected on Flat Creek; Julian Creek Mine was active on the George River; Chicken Creek Mining explored in the FlatIditarod area, and $\mathrm{H} \& \mathrm{H}$ Exploration and Mining dug 
some test pits at Meadow Lake near Iliamna.

No exploration was reported for coal or industrial minerals in the southwestern region in 1997.

\section{ALASKA PENINSULA REGION}

The only exploration in the region was for sand and gravel resources by the Bristol Bay Native Corp.

\section{SOUTHEASTERN REGION}

Reported exploration expenditures in this region were $\$ 8.83$ million, a slight increase over the $\$ 7.2$ million invested in 1996.

\section{Metals}

At the Niblack Mine on the southeastern end of Prince of Wales Island, Abacus acquired the Trio and Broadgauge claims east of its main target at the Lookout Zone, and had a 39,000-foot diamond-drill program. They recently announced an inferred mineral resource for the Lookout Zone of 2.78 million tons grading 0.087 ounces per ton gold, 1.14 ounces per ton silver, 1.70 percent copper and 3.30 percent zinc. Abacus and Teck plan a 2,000-foot exploration adit heading west from the Trio Zone into the Lookout for 1998.

The City of Wrangell provided matching funds to the federal Bureau of Land Management to contract an air- borne geophysical survey of part of Etolin Island, Zarembo Island, and part of Kupreanof Island near Wrangell, with the expectation that the results might spur exploration investment. This area contains several known mineral deposits and is prospective for Greens Creek-type deposits. Barite was formerly mined on Castle Island within the survey area. The contract was awarded to WGM-Dighem, and DGGS managed the contract to conform to the State-sponsored surveys elsewhere. Results of the survey were released in Wrangell and Fairbanks on September 22, 1997.

At the Greens Creek Mine, Kennecott completed 90,000 feet of exploratory drilling in 1997 at the mine site, and Kennecott Exploration also had a regional program for polymetallic deposits in southeastern Alaska, including the area around Wrangell.

Coeur Alaska Inc. continued to map and sample the Kensington deposit north of Juneau concomitant with ongoing permitting. Regional exploration was also reported by Rio Algom Exploration Inc., Sealaska Corp., and Hyak Mining Co.

Grizzly Bar Development LLC explored for placer gold at the Grizzly Bar on the Taku River south of Juneau, and both the Foster Operation and Snow Lion Mining continued exploration at their placer operations on Porcupine Creek near Haines. There was renewed interest in the rare-earth veins on Bokan Mountain near the old Ross-Adams uranium mine (fig. 7).

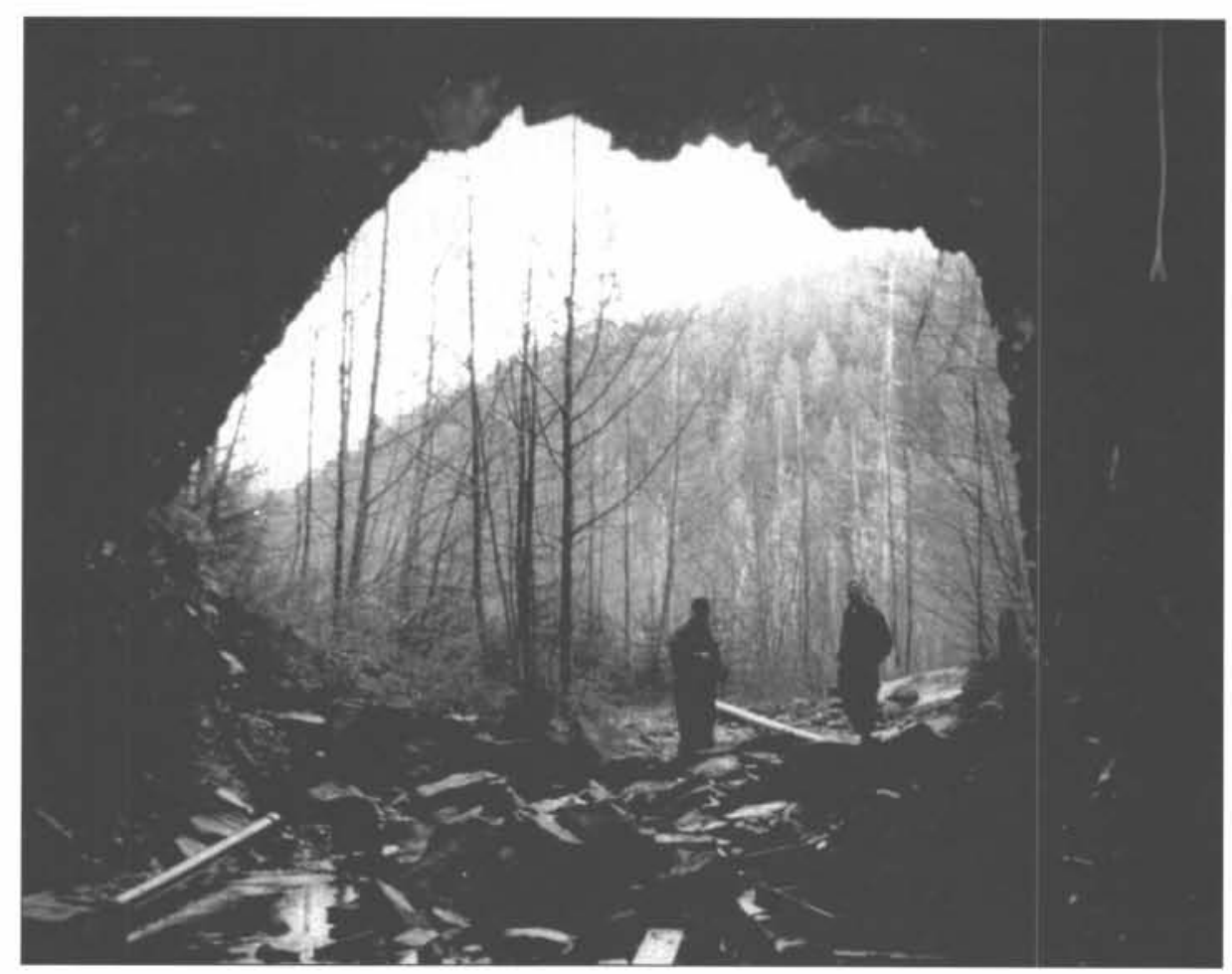

Figure 7. Jules Tileston and Bruce Campbell at the 300-foot level of the Ross-Adams uranium mine, Bokan Mountain, southeastern Alaska. Photo by Jan Nauman. 
Table 7 shows reported development expenditures by region in 1997, and table 8 shows cumulative development expenditures since 1982. Figure 8 shows the locations of selected development projects. The $\$ 168.4$ million expended in 1997 is down considerably from the $\$ 394.0$ million spent in 1996 because the Illinois Creek gold mine near Galena and the Fort Knox gold mine near Fairbanks became operational, and the Greens Creek Mine near Juneau had reached full productivity.

\section{NORTHERN REGION}

The \$133.9 million development expenditure reported at the Red Dog Mine and port site are part of the production rate increase (PRI) project that began in 1996. The project is designed to allow a 35 percent increase in production which will be phased in beginning in early summer of 1998. Cominco Alaska Inc. funded the developments at the mine site, and the State of Alaska funded the upgrade of the port facilities through the Alaska Industrial Development and Export Authority (AIDEA).

At the port site, the original 1.2 million gallon fuel storage tank was moved to the mine, and a new 2.4 million gallon tank constructed. The accommodations and ancillary facilities were expanded, and the concentrate storage and load-out facilities increased (fig. 9).

At the mine site an additional drill, Caterpillar tractor, loader, and truck were added to the fleet and at the mill a new 42-inch gyratory crusher was added, the ore storage facility modified, and the grinding and recovery systems upgraded. A fifth wing with 80 additional rooms was added to the accommodations complex.

About 800 people were on site in 1997, including the regular workforce of about 479 .

Cominco also completed 25,000 feet of development drilling in the area of the main pit and 205,000 feet of blast-hole drilling.

\section{WESTERN REGION}

Expenditures in this region in 1997 were $\$ 12.6$ million, only about 38 percent of the $\$ 32.6$ million in 1996.

Alaska Gold Co. continued its open-pit operation at Nome, and the 1997 program included a 17,000-foot churn-drill program to develop reserves. Several of the smaller placer mines on the Seward Peninsula also reported some development work including stripping the overburden from the pay gravel, constructing roads and ponds, and reclamation.

\begin{tabular}{|c|c|c|c|c|c|c|}
\hline & Northern & Western & $\begin{array}{l}\text { Eastern } \\
\text { interior }\end{array}$ & $\begin{array}{l}\text { South- } \\
\text { central }\end{array}$ & $\begin{array}{l}\text { South- } \\
\text { eastern }\end{array}$ & Total \\
\hline \multicolumn{7}{|c|}{ Development expenditures } \\
\hline Base metals & $\$ 133,880,000$ & $\ldots$ & - & -. & $\$ \quad \ldots$ & $\$ 133,880,000$ \\
\hline Polymetallic & 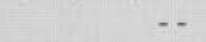 & $\cdots$ & -. & -. & $7,300,000$ & $7,300,000$ \\
\hline \multicolumn{7}{|l|}{ Precious metals } \\
\hline Placer & $\cdots$ & 540,000 & 250,000 & 49,000 & 8,000 & 847,000 \\
\hline Lode & $\ldots$ & $12,100,000$ & $5,852,000$ & $\ldots$ & $7,500,000$ & $25,452,000$ \\
\hline Coal and peat & - & 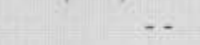 & 310,000 & 100,000 & $\ldots$ & 410,000 \\
\hline Industrial minerals & -. & -. & 100,000 & $\ldots$ & 400,000 & 500,000 \\
\hline \multirow[t]{2}{*}{ TOTAL } & $\$ 133,880,000$ & $\$ 12,640,000$ & $\$ 6,512,000$ & $\$ 149,000$ & $\$ 15,208,000$ & $\$ 168,389,000$ \\
\hline & & \multicolumn{3}{|c|}{ Development employment } & & \\
\hline \multicolumn{7}{|l|}{ Employment } \\
\hline Workdays & 72,240 & 13,588 & 5,357 & 450 & 14,566 & 106,201 \\
\hline Workyears $^{\mathrm{a}}$ & 278 & 52 & 21 & 2 & 56 & 409 \\
\hline \multicolumn{7}{|c|}{ Number of companies } \\
\hline reporting ${ }^{b}$ & 2 & 5 & 14 & 4 & 5 & 30 \\
\hline
\end{tabular}


Table 8. Reported mineral development expenditures in Alaska by commodity, 1982-97

\begin{tabular}{|c|c|c|c|c|c|c|}
\hline & Base metals & Polymetallics & Precious metals & Industrial minerals & Coal and peat & Total \\
\hline 1982 & $\$ 10,270,000$ & N/A & $\$ 19,320,000$ & $\$ 4,251,000$ & $\$ 7,750,000$ & $41,591,000$ \\
\hline 1983 & $19,500,000$ & N/A & $7,112,500$ & $1,000,000$ & 250,000 & $27,862,500$ \\
\hline 1984 & $10,710,500$ & N/A & $15,058,555$ & 579,000 & $27,000,000$ & $53,348,055$ \\
\hline 1985 & $13,000,000$ & N/A & $16,890,755$ & $1,830,000$ & $2,400,000$ & $34,120,755$ \\
\hline 1986 & $3,260,800$ & $8,000,000$ & $12,417,172$ & 124,000 & 530,000 & $24,331,972$ \\
\hline 1987 & $38,080,000$ & $48,000,000$ & $13,640,848$ & 188,000 & 342,000 & $100,250,848$ \\
\hline 1988 & $165,500,000$ & $69,000,000$ & $40,445,400$ & $\ldots$ & .. & $274,945,400$ \\
\hline 1989 & $118,200,000$ & 411,000 & $6,465,350$ & $7,000,000$ & $2,196,000$ & $134,272,350$ \\
\hline 1990 & $=\quad \cdots$ & $4,101,000$ & $7,136,500$ & 30,000 & $3,079,000$ & $14,346,500$ \\
\hline 1991 & $\ldots$ & $8,000,000$ & $14,994,350$ & 262,000 & $2,318,000$ & $25,574,350$ \\
\hline 1992 & 80,000 & $4,300,000$ & $23,151,300$ & 404,000 & $1,655,000$ & $29,590,300$ \\
\hline 1993 & $\ldots$ & $10,731,136$ & $15,103,000$ & 433,500 & $1,400,000$ & $27,667,636$ \\
\hline 1994 & $10,000,000$ & $5,000,000$ & $27,392,850$ & 5,000 & $2,545,000$ & $44,942,850$ \\
\hline 1995 & $11,200,000$ & $9,590,000$ & $127,165,750$ & 426,000 & 200,000 & $148,581,750$ \\
\hline 1996 & $60,000,000$ & $60,100,000$ & $273,042,000$ & 495,000 & 400,000 & $394,037,000$ \\
\hline 1997 & $133,880,000$ & $7,300,000$ & $26,299,000$ & 500,000 & 410,000 & $168,389,000$ \\
\hline TOTAL & $\$ 593,681,300$ & $\$ 234,533,136$ & $\$ 645,635,330$ & $\$ 17,527,500$ & $\$ 52,475,000$ & $\$ 1,543,852,266$ \\
\hline
\end{tabular}

N/A = Figures not available prior to 1986.

- Not reported.

\section{Northern Region}

1. Red Dog-Cominco Alaska Inc. (mill circuit/ port storage)

II Western Region

2. Nome area-Alaska Gold Co. (stripping pit)

3. Nixon Fork-Consolidated Nevada Goldfield Corp. (underground)

4. Illinois Creek-Dakota Mining Corp. (pit development and heap leach pad preparation)

III Eastern Interior Region

5. Fairbanks area

a. Fort Knox-Fairbanks Gold Mining Inc. (drilling, tailing dam construction)

b. Several open pit and underground placer mines

6. Healy Clean Coal

Project-Usibelli Coal Mine Inc.

\section{Southcentral Region}

\section{Southwestern Region}

7. Several placer mines (stripping overburden)

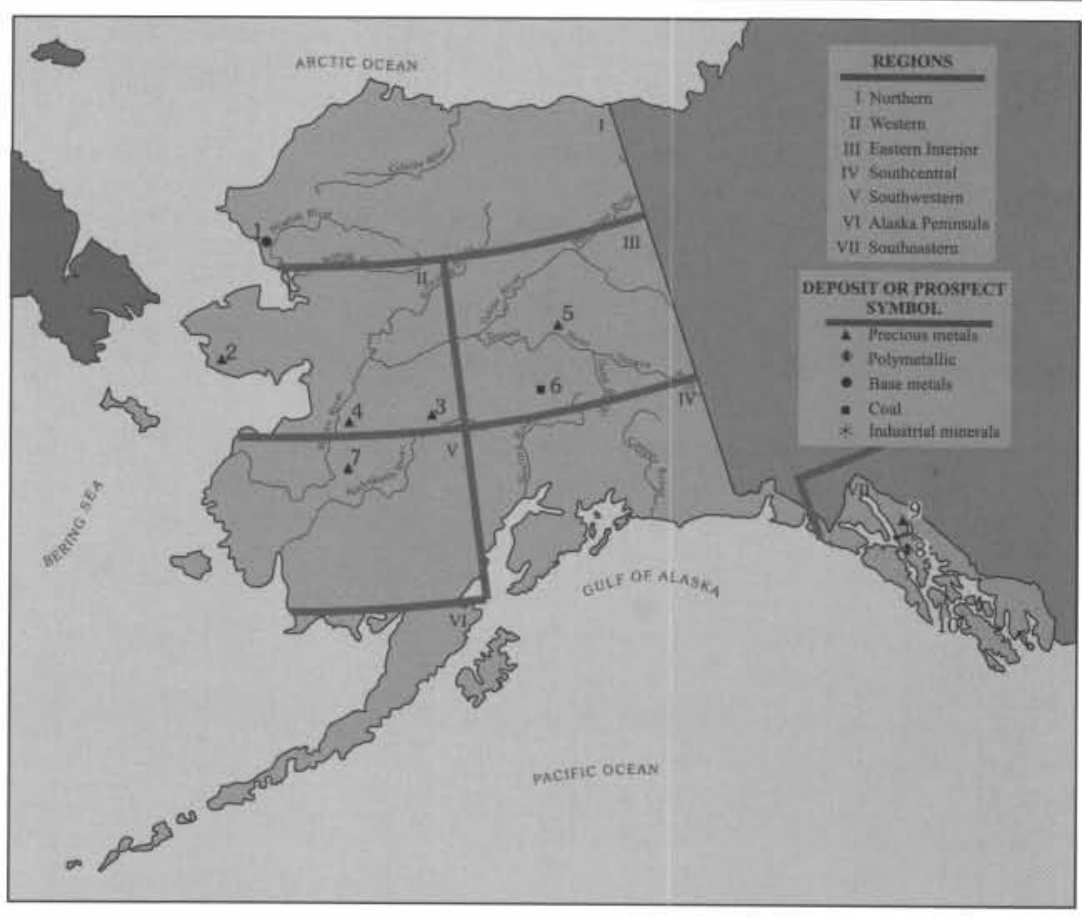

VI Alaska Peninsula Region

VII Southeastern Region

8. Greens Creek-Kennecott Greens Creek Mining Co. (access drifting)

9. Kensington Mine - Coeur Alaska Inc. (engineering and baseline studies)

10. Calder limestone-Sealaska Corp. (pit preparation)

Figure 8. Selected mineral development projects in Alaska, 1997. 

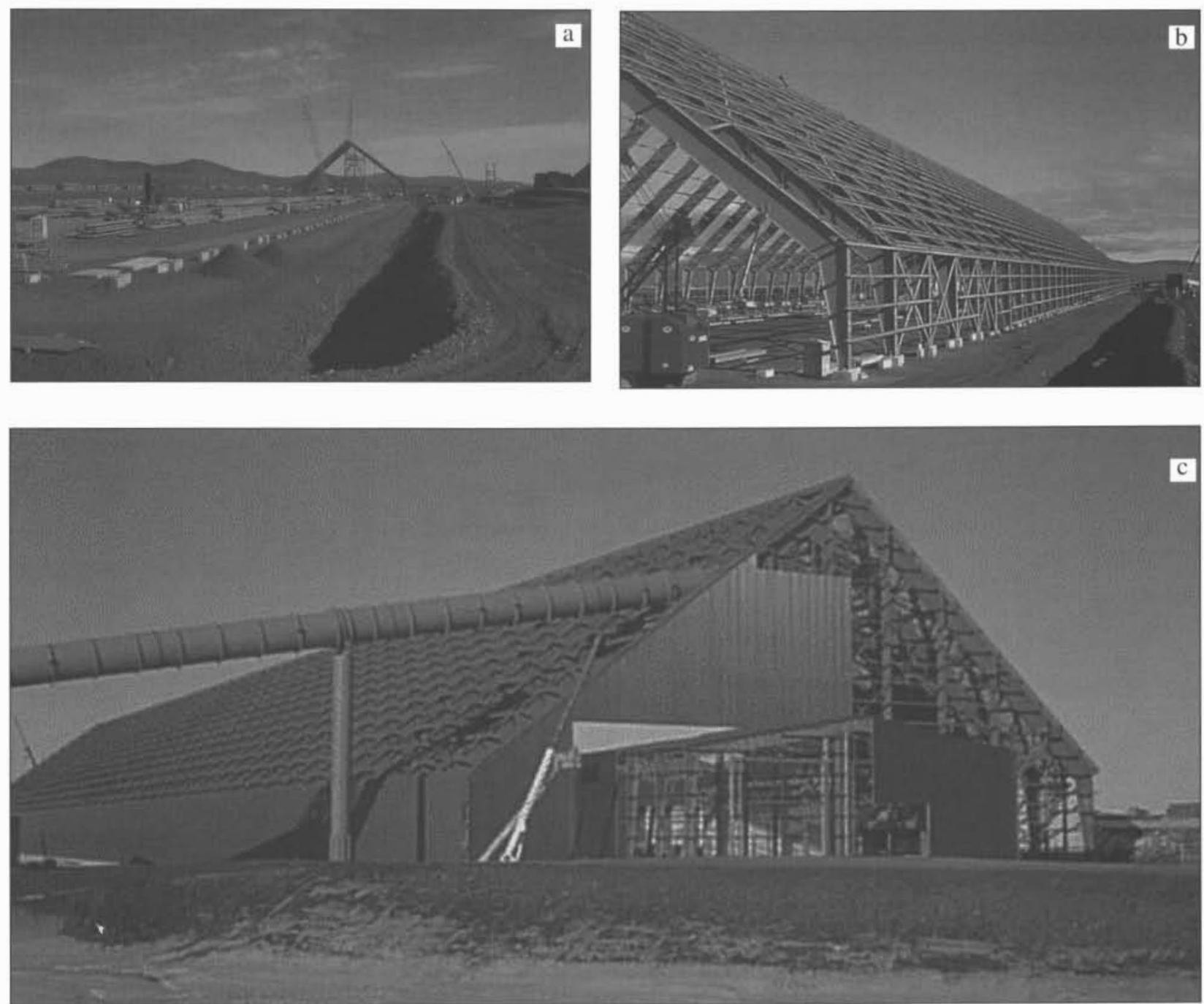

Figure 9. Stages in the development of the new zinc concentrate storage building at the Red Dog port site south of Kivalina(a) initial earthwork, July; (b) structured steel, September; and (c) roofed in November 1997. Note wash bay for vehicles. The building is 1,200 feet long, 118 feet wide, and 125 feet high, and can store 450,000 tons of zinc concentrate. Photos by John Wood.

At Dakota Mining Co.'s Illinois Creek gold-silver mine south of Galena, construction continued; by mid year the project had evolved into a production facility.

Consolidated Nevada Goldfields continued development of its Nixon Fork gold-copper mine near McGrath, driving almost 3,500 feet of 10 foot by 14 foot decline to access the deeper orebodies.

\section{EASTERN INTERIOR REGION}

The only major metal development in this region was at the Fort Knox gold mine where work continued on the tailings dam and some modifications were made to the leach tanks. An in-pit drilling program of 38,000 feet was completed, resulting in an addition of approximately 450,000 ounces to the reserve base in 1997.
Many of the small placer mines reported development of their properties, generally consisting of stripping and thawing ground in preparation for mining, and construction of settling ponds, roads and other facilities. Mines reporting development in the Rampart-Manley area include Bed Rock Enterprises (Killarney Creek); Kelley Mining Co. (Manley area); and Slate Creek Mining Co. on Slate Creek. In the Circle area KMM (Faith Creek), Paul \& Co. (Bonanza Creek) and Underwood Mining Co. (Bonanza and Porcupine creeks) all reported stripping overburden. A.M. Mining Ltd. (Dome Creek) and Tillicum Resources Inc. (Fox) both reported development in the Fairbanks district. In the Fortymile area Harvey Bickell (Walker Fork), Scott Reed (North Fork), Hayden Exploration \& Mining (KAL Creek near Eagle), EBP 
(Smith Bench), and 45-Pup Mining all reported overburden removal.

\section{COAL}

Usibelli Coal Mine Inc. drilled 2,658 feet of reversecirculation drill holes to develop its Poker Flats lease, and 2,800 feet at the Two Bull Run lease.

\section{INDUSTRIAL Minerals}

Globe Creek Mining Inc. prepared its Globe Creek limestone operation for mining and constructed road access to the haul road.

\section{SOUTHCENTRAL REGION}

Lake Creek Placers reported ground preparation at its Lake Creek gold placer mine, and Middle Fork Mine stripped overburden at its Ruby Gulch property.

Nerox Power Systems Inc. began preparation of the portal at the Jonesville coal mine east of Palmer with the intent of mining about 550,000 tons per year in the next few years.

\section{SOUTHEASTERN REGION}

About $\$ 15.2$ million was invested in this region in 1997 on development projects at the Kensington, Alaska-Juneau (A-J) and Greens Creek mines, and at the Calder Island limestone quarry.

Coeur Alaska continued its permitting process for the Kensington Mine. In August the U.S. Forest Service approved the Final Supplemental Environmental Impact Statement, and signed the Record of Decision. The City \& Borough of Juneau approved the Large Mine Permit in early November, leaving only the Corps of Engineers 404, the EPA discharge, and the State DEC Solid Waste permits to be approved.

At the Greens Creek mine, Kennecott reported 30,000 feet of development drilling concomitant with the ongoing exploration project.

Kvaerner Environmental began the reclamation of the A-J Mine in preparation for the ultimate closure.

Sealaska Corp. began preparation of its Calder Island chemical-grade limestone quarry, and started the design for the terminal facility.

\section{PRODUCTION}

The total 1997 value of production in Alaska, $\$ 936.2$ million, was up 59 percent from the $\$ 590.4$ million in 1996. With the commissioning of the Fort Knox and Illinois Creek gold mines, and full production at the Greens Creek polymetallic mine, there was an increase in the amount of gold and silver production in 1997, and production of lead and zinc increased slightly at the Red Dog Mine. These factors, coupled with higher average prices for zinc than in 1996, led to a much higher value of base and precious metals for 1997.

Table 9 shows the quantity and value for the metals and materials produced from 1995 to 1997. Figures 10, 11 , and 12 show the historic production of sand and gravel, gold, and coal.

Table 10 shows the metal mines reporting production or identified by the Division of Mining \& Water Management as producers by region, mining district, and by type. In a departure from past reports, only selected mines in the districts will be discussed in text.

Zinc, with a value of $\$ 495$ million, is by far the most important commodity produced, representing 53 percent of the total, followed a distant second by gold, with a value of \$207 million, representing 22 percent of the total. These are followed by silver ( $\$ 71$ million, 8 percent), sand and gravel ( $\$ 52$ million, 6 percent), lead (\$50 million, 5 percent), coal ( $\$ 38$ million, 4 percent), and rock ( $\$ 20$ million, 2 percent).

Zinc and lead production was from the Red Dog Mine near Kotzebue and the Greens Creek Mine near Juneau; copper was from the Greens Creek Mine near Juneau and the Nixon Fork Mine near McGrath; silver was produced at Red Dog, Greens Creek, and Illinois Creek; and gold production was from Greens Creek, Nixon Fork, Illinois Creek, Fort Knox, and 114 placer gold mines. Figure 13 shows the location of selected mines.

These production estimates for 1997 were compiled from 194 DGGS questionnaires returned from Native corporations, mine operators, agencies, and municipalities, supplemented by about 60 phone surveys. The Alaska Placer Mining Applications (APMAs) were used to cross-check for missing information, but the authors were unable to contact some operators, so the placer mine production is of necessity a conservative value. The authors particularly wish to thank the State Department of Transportation \& Public Facilities and the Department of Natural Resources Divisions of Mining \& Water Management and of Land for their assistance in securing as much information as possible.

About half of the respondents provided costs and unit values for their commodities, but the metal values were computed from the weekly averages on the London Exchange, and the values reported in table 9 do not take into account mining, shipping, smelting, or other costs incurred by the reporting company.

It is of interest that in 1997, for the first time in over 50 years, hardrock gold production ( 481,439 ounces) exceeded placer gold production (109,077 ounces) and 
Table 9. Estimated mineral production in Alaska, 1995-97a

\begin{tabular}{|c|c|c|c|c|c|c|}
\hline \multirow[b]{2}{*}{ Metals } & \multicolumn{3}{|c|}{ Quantity } & \multicolumn{3}{|c|}{ Estimated values $^{b}$} \\
\hline & 1995 & 1996 & 1997 & 1995 & 1996 & 1997 \\
\hline Gold (ounces) & 141,882 & 161,565 & 590,516 & $\$ 56,043,390$ & $\$ 62,622,594$ & $\$ 207,287,000$ \\
\hline Silver (ounces) & $1,225,730$ & $3,676,000$ & $14,401,165$ & $6,655,714$ & $19,078,440$ & $70,710,000$ \\
\hline Copper (tons) & NR & 390 & 1,720 & NR & 803,400 & $3,543,000$ \\
\hline Lead (tons) & 58,530 & 70,086 & 88,560 & $34,428,600$ & $52,284,000$ & $49,593,000$ \\
\hline Zinc (tons) & 359,950 & 366,780 & 419,097 & $345,552,000$ & $361,646,000$ & $494,888,000$ \\
\hline Subtotal & & & & $\$ 442,679,704$ & $\$ 496,434,434$ & $\$ 826,021,000$ \\
\hline \multicolumn{7}{|l|}{ Industrial minerals } \\
\hline Jade and soapstone (tons) & 2.0 & 2.0 & 2.0 & $\$ \quad 25,000$ & $\$ \quad 25,000$ & $\$ \quad 25,000$ \\
\hline Sand and gravel (million tons) & 9.8 & 9.9 & 13.8 & $30,886,821$ & $32,203,260$ & $51,913,000$ \\
\hline Rock (million tons) & 2.8 & 3.0 & 3.2 & $22,163,703$ & $23,557,637$ & $20,000,000$ \\
\hline Subtotal & & & & $\$ 53,075,524$ & $\$ 55,785,897$ & $\$ 71,938,000$ \\
\hline \multicolumn{7}{|l|}{ Energy minerals } \\
\hline Coal (tons) & $1,670,000$ & $1,481,000$ & $1,446,000$ & $\$ 41,300,000$ & \$ $38,000,000$ & $\$ 38,048,000$ \\
\hline Peat (cubic yards) & 35,000 & 38,000 & 38,500 & 157,500 & 175,000 & 192,000 \\
\hline Subtotal & & & & $\$ 41,457,500$ & $\$ 38,175,000$ & $\$ 38,240,000$ \\
\hline TOTAL & & & & $\$ 537,212,728$ & $\$ 590,395,331$ & $\$ 936,199,000$ \\
\hline
\end{tabular}

aProduction data from DGGS questionnaires, phone interviews with mine and quarry operators, Alaska Department of Transportation and Public Facilities, and federal land management agencies.

bValues for selected metal production based on average prices for each year; for 1997—gold ( $\$ 330.76 /$ ounce) unless other value provided by operator; silver $(\$ 4.91 /$ ounce); copper $(\$ 1.03 / \mathrm{lb})$; zinc $(\$ 0.59 / \mathrm{lb})$; lead $(\$ 0.28 / \mathrm{lb})$. All other values provided by mine operators. Value rounded to nearest $\$ 1,000$.

$\mathrm{NR}=$ None reported.

Table 10. Companies and individuals reported to be producing metal in Alaska in 1997

\begin{tabular}{|c|c|c|c|}
\hline District & Operator & Creek/Mine & Type \\
\hline \multicolumn{4}{|c|}{ NORTHERN REgION } \\
\hline Noatak & Cominco Alaska Inc. & Red Dog Mine & O/P H/R Zinc-Lead-Silver \\
\hline Chandalar & Gold Dust Mines Inc. & Little Squaw & O/P Placer \\
\hline Koyukuk-Nolan & Paradise Valley Mining & Birch & O/P Placer \\
\hline Koyukuk-Nolan & Lounsbury Mining Inc. & Union Gulch & O/P Placer \\
\hline Koyukuk-Nolan & Don Wiggers & Hammond River & $\mathrm{O} / \mathrm{P}$ Placer \\
\hline \multicolumn{4}{|c|}{ Western Region } \\
\hline Kaiyuh & Dakota Mining Corp. & Illinois Creek Mine & O/P H/R Gold-Silver \\
\hline Cape Nome & Alaska Gold Co. & Nome submarine beach & $\mathrm{O} / \mathrm{P}$ Placer \\
\hline Cape Nome & Betty Krutzch & Basin & O/P Placer \\
\hline Cape Nome & Bert Pettigrew & Anvil & O/P Placer \\
\hline Cape Nome & Alfred Turner & Center & $\mathrm{O} / \mathrm{P}$ Placer \\
\hline Cape Nome & Steve Pomrenke & Tripple & O/P Placer \\
\hline Cape Nome & High Bench Mining & Nekula Gulch & O/P Placer \\
\hline Cape Nome & Perry Massie & Cripple & O/P/Placer \\
\hline Cape Nome & Dave Olson & Canyon & O/P Placer \\
\hline Cape Nome & John Walsh & Mystery & $\mathrm{O} / \mathrm{P}$ Placer \\
\hline Port Clarence & William Bartholomae & Gold Run & O/P Placer \\
\hline Fairhaven & Layne Gardner & Bear, Gold Run & O/P Placer \\
\hline
\end{tabular}


Table 10. Companies and individuals reported to be producing metal in Alaska in 1997-continued

\begin{tabular}{|c|c|c|c|}
\hline District & Operator & Creek/Mine & Type \\
\hline Kougarok & N. B. Tweet \& Sons & Kougarok & O/P Placer \\
\hline Kougarok & Lohman Mining & Coffee & O/P Placer \\
\hline Kougarok & A \& L Mining & Coffee & $\mathrm{O} / \mathrm{P} / \mathrm{Placer}$ \\
\hline Kougarok & Cheryl Jong & Washington & O/P Placer \\
\hline Kougarok & Richard Redmond & Macklin & O/P Placer \\
\hline Kougarok & Mark Gumaer & Dick & O/P Placer \\
\hline Candle & Mike Vial & Mud & $\mathrm{O} / \mathrm{P}$ Placer \\
\hline Candle & Dave Vial & Candle & O/P Placer \\
\hline Candle & Alan Olson & Candle & O/P Placer \\
\hline Ruby & Conrad House & Swift & $\mathrm{O} / \mathrm{P}$ Placer \\
\hline McGrath & Consolidated Nevada Goldfields Inc. & Nixon Fork Mine & U/G H/R Gold-Copper-Silver \\
\hline McGrath & Manzie Magnuson & Candle & O/P Placer \\
\hline Innoko & Rosander Mining & Colorado & O/P Placer \\
\hline Hughes & Taiga Mining Co. Inc. & Dry & O/P Placer \\
\hline \multicolumn{4}{|c|}{ EASTERN INTERIOR REgION } \\
\hline Hot Springs & Salter \& Associates Inc. & Doric & O/P Placer \\
\hline Hot Springs & Rick Swenson & Doric & O/P Placer \\
\hline Hot Springs & Ross Novak & Eureka & O/P Placer \\
\hline Hot Springs & Ross Novak & American & O/P Placer \\
\hline Hot Springs & Ernest Johnson & Glen & O/P Placer \\
\hline Hot Springs & Jay Hodges & American & O/P Placer \\
\hline Hot Springs & James Wood & Little Boulder & O/P Placer \\
\hline Hot Springs & Placer Mine Services & Boulder & O/P Placer \\
\hline Hot Springs & Terry Russell & Ready Money & O/P Placer \\
\hline Hot Springs & Jack Neuebauer & Tofty-Woodchopper & O/P Placer \\
\hline Rampart & Frank Willford & Hoosier Tributary & O/P Placer \\
\hline Rampart & Steve Losonsky & Hunter & $\mathrm{O} / \mathrm{P}$ Placer \\
\hline Rampart & Don Harris & Slate & O/P Placer \\
\hline Melozitna & Wayne Gibson & Golden & $\mathrm{O} / \mathrm{P}$ Placer \\
\hline Tolovana & Alaska Placer Development & Livengood & O/P Placer \\
\hline Tolovana & Samuel Eaves & Warwick Gulch & O/P Placer \\
\hline Fairbanks & Fairbanks Gold Mining Inc & Fort Knox Mine & $\mathrm{O} / \mathrm{P} \mathrm{H} / \mathrm{R}$ Gold \\
\hline Fairbanks & Polar Mining Inc. & Goldstream & O/P Placer \\
\hline Fairbanks & Yellow Eagle Mining Co. & Cripple & O/P Placer \\
\hline Fairbanks & Gerald Hassel & Ready Bullion & O/P Placer \\
\hline Fairbanks & Roger Moore & Seattle Bench & O/P Placer \\
\hline Fairbanks & S.D.C. Mining & Dome & $\mathrm{O} / \mathrm{P}$ Placer \\
\hline Fairbanks & A.M. Mining Ltd. & Dome & O/P Placer \\
\hline Fairbanks & Lucky-7 Mining & Last Chance & O/P Placer \\
\hline Fairbanks & Cook's Mining & Lower Fairbanks & O/P Placer \\
\hline Fairbanks & Alf Hopen & Cleary & O/P Placer \\
\hline Fairbanks & Don Read & Vault & O/P Placer \\
\hline Fairbanks & Andy Miscovich & Chatham & O/P Placer \\
\hline Fairbanks & Tillicum Resources Inc. & Fox & O/P Placer \\
\hline Fairbanks & KMM Co. & Faith & O/P Placer \\
\hline Fairbanks & John Hannah & Moose/Pedro/Flume & O/P Placer \\
\hline Fairbanks & Robert Wright & Last Chance & $\mathrm{O} / \mathrm{P}$ Placer \\
\hline Fairbanks & Chris Groppel & Tenderfoot & O/P Placer \\
\hline Fairbanks & Earl Voytilla & Tenderfoot & O/P Placer \\
\hline Fairbanks & John Rubel & Banner & $\mathrm{O} / \mathrm{P} / \mathrm{Placer}$ \\
\hline Fairbanks & AU Mining & Chatanika/Cleary & U/G Placer \\
\hline Fairbanks & Little Eldorado Group & Little Eldorado & U/G Placer \\
\hline Circle & Shorti-Jack Mining & Eagle & O/P Placer \\
\hline Circle & Steve Olson & Eagle & O/P Placer \\
\hline Circle & Paul and Company & Bonanza & O/P Placer \\
\hline Circle & Douglas Miller & Bonanza & O/P Placer \\
\hline Circle & Aurora Mining & North Fork Harrison & O/P Placer \\
\hline
\end{tabular}


Table 10. Companies and individuals reported to be producing metal in Alaska in 1997-continued

\begin{tabular}{|c|c|c|c|}
\hline District & Operator & Creek/Mine & Type \\
\hline Circle & Richard Loud & North Fork Harrison & O/P Placer \\
\hline Circle & Lapp and Sons & Ketchum & $\mathrm{O} / \mathrm{P}$ Placer \\
\hline Circle & Arctic Mining & Crooked & O/P Placer \\
\hline Circle & Dan Mandrones & Crooked & O/P Placer \\
\hline Circle & Rock Laundry Mining & Crooked & O/P Placer \\
\hline Circle & Willis Mine Services & Crooked & O/P Placer \\
\hline Circle & Stan Gelvin & Crooked & O/P Placer \\
\hline Bonnifield & Tim Kiehl & Gold King & O/P Placer \\
\hline Bonnifield & TruDeck Mining & Sheep & $\mathrm{O} / \mathrm{P}$ Placer \\
\hline Bonnifield & Robert Keller & Totatlanika & O/P Placer \\
\hline Bonnifield & Roy Traxler & Totatlanika & O/P Placer \\
\hline Bonnifield & Ralph Simonson & Surprise & O/P Placer \\
\hline Bonnifield & David Jacobs & $\operatorname{Rex}$ & $\mathrm{O} / \mathrm{P} / \mathrm{Placer}$ \\
\hline Bonnifield & Wayne Tachick & Moose & $\mathrm{O} / \mathrm{P}$ Placer \\
\hline Bonnifield & Tom Faa & Moose & O/P Placer \\
\hline Bonnifield & Glen Parr & Little Moose & $\mathrm{O} / \mathrm{P}$ Placer \\
\hline Fortymile & Harvey Bickell & Walker Fork Fortymile & O/P Placer \\
\hline Fortymile & Fred Heflinger & Walker Fork Fortymile & O/P Placer \\
\hline Fortymile & Double J Mining & Napoleon & O/P Placer \\
\hline Fortymile & Brad Carr & South Fork Fortymile & O/P Placer \\
\hline Fortymile & Walter Schofield & South Fork Fortymile & O/P Placer \\
\hline Fortymile & Roger Tallini & South Fork Fortymile & O/P Placer \\
\hline Fortymile & Taylor's Mining & Fortymile & O/P Placer \\
\hline Fortymile & James Treesh & Fortymile & O/P Placer \\
\hline Fortymile & Jensen Mining \& Construction & McCumber & O/P Placer \\
\hline Fortymile & 45 Pup Mining & 45 Pup & O/P Placer \\
\hline Fortymile & Scott Reed & North Fork Fortymile & O/P Placer \\
\hline Fortymile & Guy Fichtelman & Mosquito Fork & O/P Placer \\
\hline Fortymile & Leo Regner & Lilliwig & O/P Placer \\
\hline Fortymile & Hayden Exploration \& Mining & Squaw (KAL) & $\mathrm{O} / \mathrm{P}$ Placer \\
\hline \multirow[t]{2}{*}{ Fortymile } & Geo Quest & Chicken & O/P Placer \\
\hline & \multicolumn{2}{|c|}{ Southcentral Region } & \\
\hline Yentna & Lake Creek Placers & Lake Creek & $\mathrm{O} / \mathrm{P}$ Placer \\
\hline Willow Creek & Mrak Placer Mine & Willow & $\mathrm{O} / \mathrm{P}$ Placer \\
\hline Tok & Middle Fork Mine & Middle Fork Chistochina & $\mathrm{O} / \mathrm{P}$ Placer \\
\hline Hope & Outsider Mining & Canyon & O/P Placer \\
\hline Hope & Gerald Willard & Bear & $\mathrm{O} / \mathrm{P} / \mathrm{Placer}$ \\
\hline \multirow[t]{2}{*}{ Anchorage } & Girdwood Mining Co. & Crow & O/P Placer \\
\hline & \multicolumn{2}{|c|}{ SOUTHWESTERn REgION } & \\
\hline Marshall & Chase Brothers Mining & Flat/Stuyahok & $\mathrm{O} / \mathrm{P}$ Placer \\
\hline Innoko & Clarke-Wiltz Partnership & Podesie/Ganes & $\mathrm{O} / \mathrm{P}$ Placer \\
\hline Innoko & Anderson Mining & Yankee & O/P Placer \\
\hline Innoko & Little Creek Mine & $10 \mathrm{Pup} /$ Little & O/P Placer \\
\hline Innoko & Ed Plano & Anvil Gulch & O/P Placer \\
\hline Innoko & Manzie Magnuson & Madison & O/P Placer \\
\hline Iditarod & Chicken Creek Mining & Chicken & $\mathrm{O} / \mathrm{P}$ Placer \\
\hline Iditarod & Flat Creek Mining Co. & Flat & O/P Placer \\
\hline Aniak & Mark Matter & Marvel & $\mathrm{O} / \mathrm{P} / \mathrm{Placer}$ \\
\hline \multirow[t]{2}{*}{ Aniak } & Nyac Mining Inc. & Bear & O/P Placer \\
\hline & \multicolumn{2}{|c|}{ SOUTHEASTERN REgION } & \\
\hline Juneau & Big Nugget Mining & Porcupine & $\mathrm{O} / \mathrm{P}$ Placer \\
\hline Juneau & Snow Lion Mining & Porcupine & $\mathrm{O} / \mathrm{P}$ Placer \\
\hline Admiralty & Kennecott/Hecla & Greens Creek Mine & U/G H/R Zinc-Lead-Gold-Silver \\
\hline
\end{tabular}

SourCE: Questionnaires and mine visits by Division of Mining \& Water Management.

$\mathrm{O} / \mathrm{P}=$ open pit; $\mathrm{U} / \mathrm{G}=$ underground; $\mathrm{H} / \mathrm{R}=$ hard rock. 


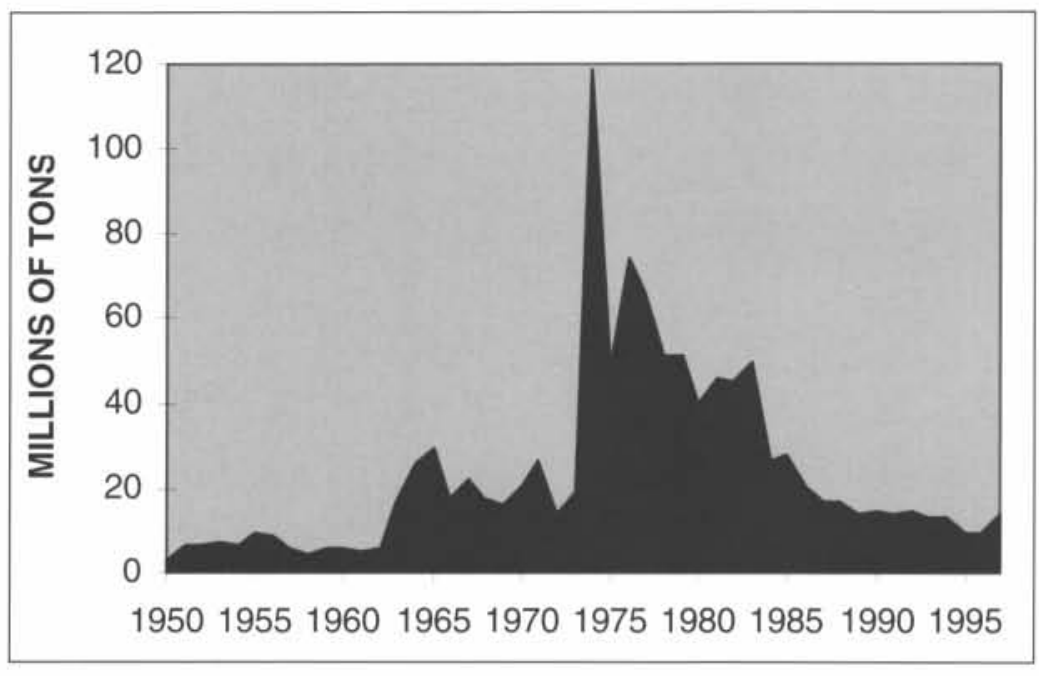

Figure 10. Sand and gravel production in Alaska, 1950-97.

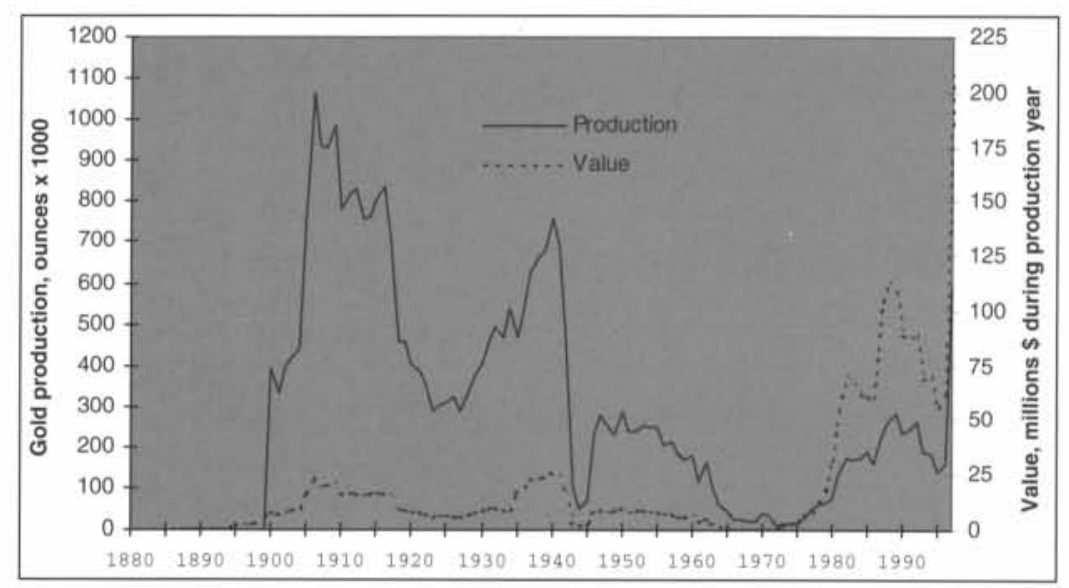

Figure 11. Amount and value of gold production in Alaska, 1880-1997.

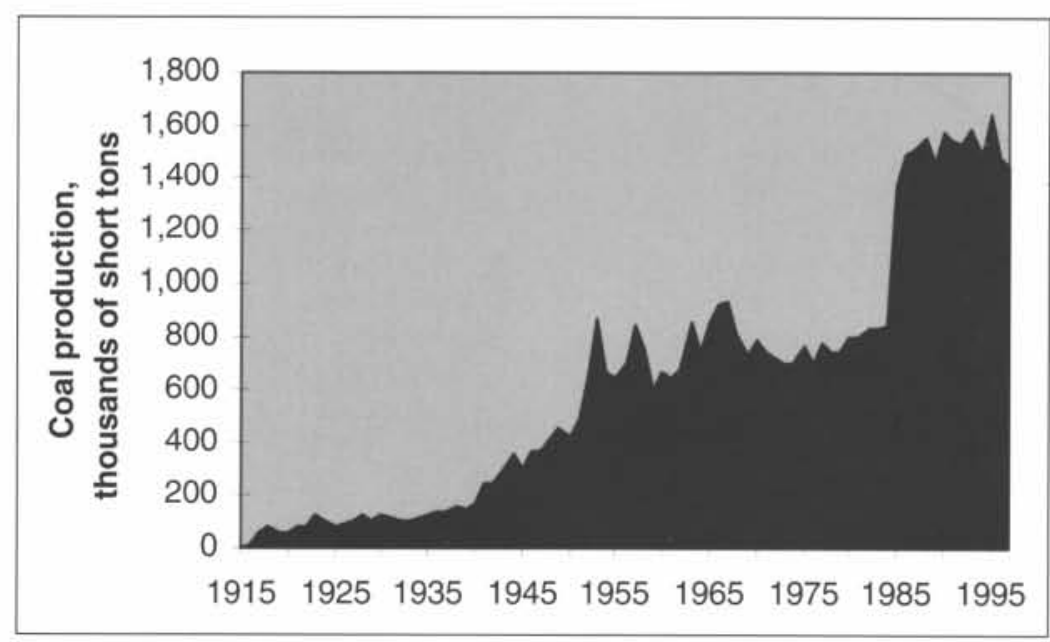

Figure 12. Coal production in Alaska, 1915-97. this situation is expected to continue for the foreseeable future. Table 11 shows the relative importance of the six regions of Alaska where gold production was reported, and table 12 shows the production costs for small (less than 650 ounces production), medium ( 650 to 2,500 ounces), and large (over 2,500 ounces) gold operations. It should be noted that reported production costs vary widely within the groups, and that companies reporting costs are too few to be statistically meaningful.

Tables 13 and 14 show the amount and value of sand, gravel, and rock reportedly used in 1997 in the seven regions of the state. By far the greatest use of these materials is in road construction and maintenance.

The total value of sand and gravel in 1997 was $\$ 51.9$ million for 13.8 million tons. The majority of sand and gravel used was in the southcentral region of the state on reconstruction projects on the Parks, Glenn, and Seward highways, but completion of the Geist Road overpass and other roadwork in the Eastern interior region, and oilfield and road construction in the northern region contributed to the higher-than-normal use of these materials.

Virtually all of the 3.2 million tons of rock used in the state was for construction material in southeastern Alaska, mainly for road maintenance in the Tongass National Forest and some of the municipalities, and as fill material for the ferry terminal site near Juneau. The total value is estimated to be $\$ 20$ million, based on the values per ton reported by several private vendors.

Coal production in 1997 was slightly less than in 1996, with 650,000 tons shipped to Korea and the remainder sold to interior Alaska power plants. A new 50-megawatt mine-mouth clean coal power plant is scheduled to burn about 300,000 tons of coal when it is running at full production in 1999. Production of peat was up slightly in 1997, mostly for use in local horticulture. 


\section{Northern Region}

1. Red Dog Mine, Noatak district-zinc-lead-silver (germanium)

2. Little Squaw Gold Mining Co. placer properties, Chandalar district-gold-silver

3. Prudhoe Bay and Kuparuk pits (numerous) - sand and gravel

\section{Western Region}

4. Alaska Gold Co. open pit placer mines, Cape Nome district-gold-silver

5. Illinois Creek Mine-goldsilver

6. Nixon Fork Mining Co., McGrath-McKinley districtgold-copper-silver

\section{Eastern Interior Region}

7. Alaska Placer Development, Livengood-Tolovana district-gold-silver

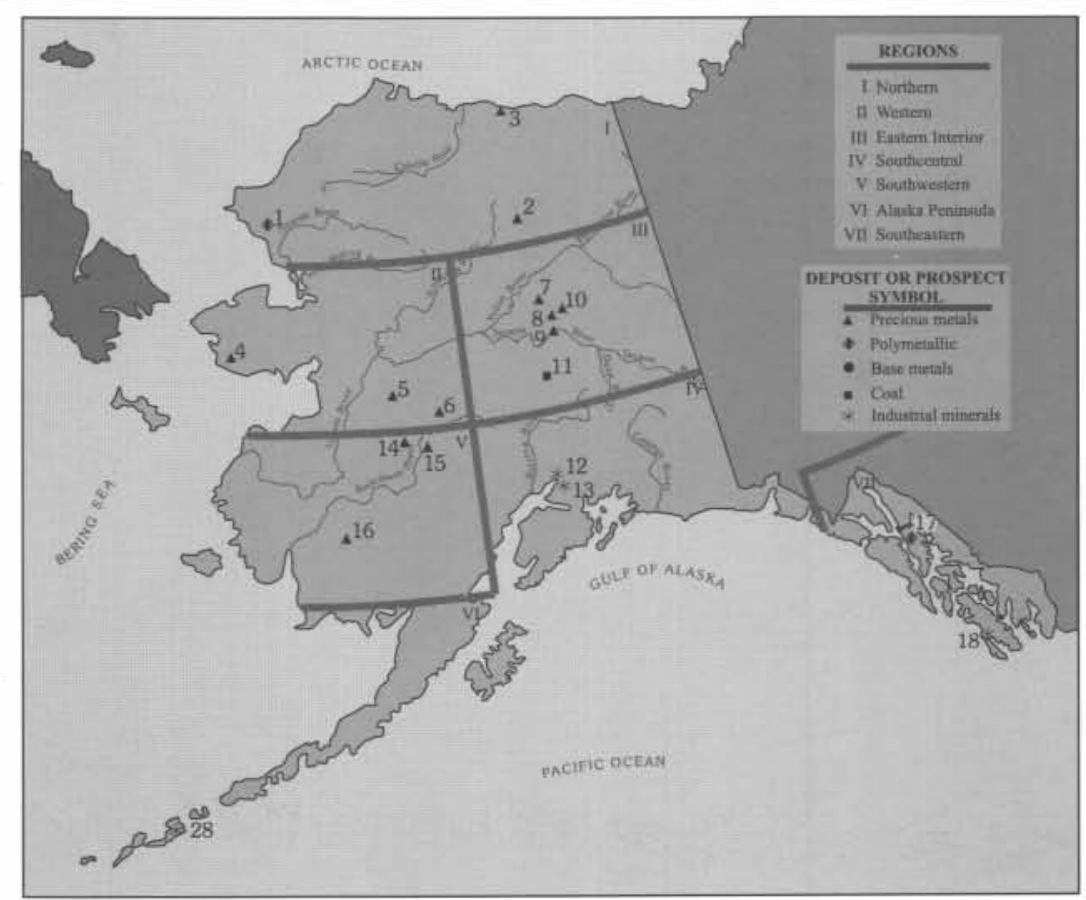

8. Yellow Eagle Mining Inc., Fairbanks district-goldsilver

9. Polar Mining Inc., Fairbanks district-gold-silver-screened aggregate

10. Fairbanks Gold Mining Inc. (Fort Knox), Fairbanks district-gold-silver

11. Usibelli Coal Mine Inc., Bonnifield district-coal

\section{Southcentral Region}

12. Landscape Supply Corp., Hatcher Pass districttopsoil-peat

13. Hermon Brothers Construction Co., Anchorage districtsand and gravel

\section{Southwestern Region}

14. Clark-Wiltz Partnership, Innoko district-gold-silver

15. Manzie Magnuson, McGrath-McKinley district-gold-silver

16. NYAC Mining Co., Nyac district-gold-silver

\section{Alaska Peninsula Region}

\section{Southeastern Region}

17. Kennecott Greens Creek Mining Co., Juneau-Admiralty district-silver-zinc-gold-lead-copper

18. Sealaska Corp., Ketchikan district-limestone

Figure 13. Selected production projects, 1997.

Table 11. Reported refined gold production, number of operators, and industry employment in Alaska, 1995-97

\begin{tabular}{|c|c|c|c|c|c|c|c|c|c|}
\hline \multirow[t]{2}{*}{ Region } & \multicolumn{3}{|c|}{ Number of operators } & \multicolumn{3}{|c|}{ Production in ounces of gold } & \multicolumn{3}{|c|}{ Number of employees } \\
\hline & 1995 & 1996 & 1997 & 1995 & 1996 & 1997 & 1995 & 1996 & 1997 \\
\hline Northern & 6 & 5 & 4 & 6,265 & 1,450 & 537 & 58 & 14 & 12 \\
\hline Western & 25 & 24 & 24 & 38,100 & 74,200 & 104,297 & 261 & 338 & 324 \\
\hline Eastern Interior & 89 & 92 & 75 & 53,690 & 74,789 & 423,676 & 376 & 456 & 548 \\
\hline Southcentral & 10 & 8 & 6 & 35,094 & 3,100 & 971 & 232 & 16 & 12 \\
\hline Southwestern & 13 & 13 & 11 & 8,548 & 8,500 & 5,070 & 80 & 80 & 57 \\
\hline Southeastern & 2 & 3 & 3 & 185 & 8,026 & 55,965 & 6 & 69 & 277 \\
\hline TOTAL & 145 & 145 & 123 & 141,882 & 170,065 & 590,516 & 1,013 & 973 & 1,230 \\
\hline
\end{tabular}

a1997 production includes 481,439 ounces gold from Nixon Fork, Illinois Creek, Fort Knox, and Greens Creek hardrock projects, and 109,077 ounces of placer gold. 
Table 12. Production costs for selected Alaska placer gold mines, 1991-97

\begin{tabular}{|c|c|c|c|c|c|c|c|}
\hline Mine size & 1991 & 1992 & 1993 & 1994 & 1995 & 1996 & 1997 \\
\hline \multicolumn{8}{|c|}{ Number of mines } \\
\hline Small ${ }^{\mathrm{a}}$ & 21 & 23 & 19 & 24 & 11 & 9 & 25 \\
\hline Medium $^{b}$ & 8 & 6 & 4 & 6 & 5 & 5 & 6 \\
\hline $\operatorname{Large}^{c}$ & 5 & 5 & 2 & 4 & 4 & 4 & 4 \\
\hline TOTAL & 34 & 34 & 25 & 34 & 20 & 18 & 35 \\
\hline \multicolumn{8}{|c|}{ Production in ounces } \\
\hline Small ${ }^{\mathrm{a}}$ & 3,582 & 3,842 & 3,919 & 2,789 & 1,459 & 1,433 & 5,077 \\
\hline Medium $^{\mathrm{b}}$ & 8,431 & 5,759 & 5,825 & 7,471 & 5,890 & 5,058 & 9,373 \\
\hline $\operatorname{Large}^{c}$ & 84,539 & 128,992 & 25,335 & 48,864 & 43,390 & 49,240 & 65,682 \\
\hline TOTAL & $96,552^{d}$ & $138,593^{e}$ & $35,079^{f}$ & $59,124^{g}$ & $50,739^{h}$ & $55,731^{i}$ & $80,132^{j}$ \\
\hline \multicolumn{8}{|c|}{ Total reported mine costs } \\
\hline Small $^{\mathrm{a}}$ & $\$ 1,018,606$ & $\$ 940,000$ & $\$ 1,031,500$ & $\$ 989,076$ & $\$ 336,300$ & $\$ \quad 389,754$ & $\$ 1,243,865$ \\
\hline Medium $^{b}$ & $2,518,239$ & $1,460,000$ & $1,905,125$ & $2,597,782$ & $1,440,000$ & $1,222,700$ & $1,696,513$ \\
\hline Large $^{c}$ & $31,857,228$ & $41,650,000$ & $7,605,000$ & $16,706,600$ & $14,795,000$ & $17,159,024$ & $21,018,240$ \\
\hline TOTAL & $\$ 35,394,073$ & $\$ 44,050,000$ & $\$ 10,541,625$ & $\$ 20,293,458$ & $\$ 16,571,300$ & $\$ 18,771,478$ & $\$ 23,958,618$ \\
\hline \multicolumn{8}{|c|}{ Unit cost per ounce } \\
\hline Small $^{\mathrm{a}}$ & $\$ 284$ & $\$ 245$ & $\$ 263$ & $\$ 354$ & $\$ 231$ & $\$ 271$ & $\$ 245$ \\
\hline Medium $^{\mathrm{b}}$ & 298 & 255 & 327 & 347 & 245 & 242 & 181 \\
\hline Large $^{\mathrm{c}}$ & 376 & 322 & 300 & 341 & 341 & 348 & 320 \\
\hline TOTAL & $\$ 367$ & $\$ 318$ & $\$ 300$ & $\$ 343$ & $\$ 327$ & $\$ 337$ & $\$ 299$ \\
\hline 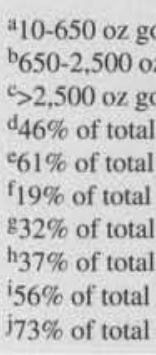 & $\begin{array}{l}\text { yr. } \\
\text { ld/yr. } \\
\text { yr. } \\
\text { aska placer gold pr } \\
\text { ska placer gold pro } \\
\text { ska placer gold pro } \\
\text { aska placer gold pro } \\
\text { aska placer gold pr } \\
\text { ska placer gold pro } \\
\text { ska placer gold pro }\end{array}$ & $\begin{array}{l}\text { duction. } \\
\text { duction. } \\
\text { luction. } \\
\text { duction. } \\
\text { duction. } \\
\text { luction. } \\
\text { luction. }\end{array}$ & & & & & \\
\hline
\end{tabular}

Table 13. Reported sand and gravel production and industry employment in Alaska by region, 1997

\begin{tabular}{|c|c|c|c|c|c|}
\hline Region & $\begin{array}{c}\text { Companies and } \\
\text { agencies reporting }\end{array}$ & Tons & $\begin{array}{l}\text { Estimated unit } \\
\text { value }(\$ / \text { ton })^{\mathrm{b}}\end{array}$ & $\begin{array}{l}\text { Total } \\
\text { value }\end{array}$ & $\begin{array}{c}\text { Estimated number } \\
\text { of employees }\end{array}$ \\
\hline Northern & 4 & $1,573,045$ & $\$ 4.50$ & $\$ 7,078,703$ & 70 \\
\hline Western & 2 & 242,000 & 4.50 & $1,089,000$ & 30 \\
\hline Eastern Interior & 9 & $2,399,900$ & 4.00 & $9,599,600$ & 195 \\
\hline Southcentral & 12 & $8,370,440$ & 3.50 & $29,296,540$ & 310 \\
\hline Southwestern & 2 & 368,000 & 2.26 & 831,680 & 30 \\
\hline Alaska Peninsula & 3 & 72,000 & 2.66 & 191,520 & 20 \\
\hline Southeastern & 7 & 728,706 & 5.25 & $3,825,706$ & 45 \\
\hline TOTAL & 39 & $13,754,091$ & 3.77 & $\$ 51,912,749$ & 700 \\
\hline
\end{tabular}




\section{NORTHERN REGION}

\section{Metals}

One hardrock open-pit mine and four conventional placer mines reported production in 1997 in this region. Placer production is shown in table 11.

The Red Dog zinc-lead-silver mine, owned by NANA Corp. and operated by Cominco Alaska Inc., produced 675,900 short dry tons of 55.2 percent zinc concentrate and 123,500 short dry tons of 56.1 percent lead concentrate from 2,127,000 tons of ore milled. Average grades of the mill-feed were 20.3 percent zinc, 5.2 percent lead and 2.9 ounces per ton silver. Operating profit for 1997 was $\$ 102$ million compared with $\$ 25$ million in 1996. Table 15 and figure 14 show production statistics for the past 8 years.

\section{Industrial Minerals}

Tables 12 and 13 show the use of sand, gravel, and rock in the various regions of the state in 1997.

Sand and gravel production in the northern region, 1.57 million tons, was similar to the 1.51 million tons produced in 1996.

A substantial quantity of sand and gravel was used by the North Slope Borough for roadwork and facilities, by British Petroleum and Arco for their oilfield facilities, and lesser amounts at the Red Dog Mine. About 30,000 tons of shot rock was also used at the mine. Most of the material, as well as that used by the Department of Transportation \& Public Facilities for airport upgrades, was derived from sales by DNR's Division of Land.

Table 14. Reported stone production and industry employment in Alaska by region, 1997a

\begin{tabular}{|c|c|c|c|c|c|}
\hline Region & $\begin{array}{c}\text { Companies and } \\
\text { agencies reporting }\end{array}$ & Tons & $\begin{array}{l}\text { Estimated unit } \\
\text { value }(\$ / \text { ton })^{\mathrm{e}}\end{array}$ & $\begin{array}{l}\text { Total } \\
\text { value }\end{array}$ & $\begin{array}{c}\text { Estimated number } \\
\text { of employees }\end{array}$ \\
\hline Northern & 2 & 20,000 & $\$ 10.00$ & 200,000 & 5 \\
\hline Western & 2 & 32,000 & 10.00 & 320,000 & 10 \\
\hline Eastern Interior & 3 & 60,220 & 10.00 & 602,200 & 15 \\
\hline Southcentral & 3 & 94,400 & 7.50 & 708,000 & 15 \\
\hline Southwestern & $\cdots$ & $\ldots$ & -. & $\ldots$ & $\cdots$ \\
\hline Alaska Peninsula & 1 & 13,500 & 10.00 & 135,000 & 3 \\
\hline Southeastern & 4 & $2,956,338$ & 6.10 & $18,033,661$ & 75 \\
\hline TOTAL & 15 & $3,176,458$ & 6.30 & $\$ 19,998,861$ & 123 \\
\hline
\end{tabular}

Table 15. Cominco Alaska's Red Dog Mine, production statistics, 1990-97

\begin{tabular}{|c|c|c|c|c|c|c|c|c|}
\hline & 1990 & 1991 & 1992 & 1993 & 1994 & 1995 & 1996 & 1997 \\
\hline Ore milled (tons) & $996,700^{\mathrm{a}}$ & $1,599,300$ & $1,582,000$ & $1,874,600^{\mathrm{a}}$ & $2,339,500$ & $2,485,900$ & $2,312,600$ & $2,127,000$ \\
\hline \multicolumn{9}{|l|}{ Ore grade } \\
\hline Zinc & $26.5 \%$ & $22.5 \%$ & $19.9 \%$ & $18.4 \%$ & $18.8 \%$ & $19.0 \%$ & $18.7 \%$ & $20.3 \%$ \\
\hline Lead & $8.5 \%$ & $6.6 \%{ }^{a}$ & $6.0 \%$ & $5.7 \%^{\mathrm{a}}$ & $5.7 \%$ & $5.8 \%$ & $5.0 \%$ & $5.2 \%$ \\
\hline Silver (oz/ton) & $3.6^{\mathrm{a}}$ & 2.8 & 2.9 & 2.8 & 2.8 & 2.8 & 2.8 & 2.87 \\
\hline \multicolumn{9}{|l|}{ Concentrate } \\
\hline Zinc (tons) & 337,400 & 410,700 & 405,900 & 465,600 & 588,100 & 645,100 & 646,800 & 675,900 \\
\hline (grade) & $56.9 \% \%^{\mathrm{a}}$ & $57.1 \%$ & $57.0 \%$ & $54.8 \%$ & $55.8 \%$ & $55.6 \%$ & $55.3 \%$ & $55.2 \%$ \\
\hline Lead (tons) & $56,600^{\mathrm{a}}$ & $76,600^{\mathrm{a}}$ & 28,000 & 48,700 & 59,700 & 101,300 & 118,500 & 123,500 \\
\hline (grade) & $55.1 \%$ & $57.2 \%$ & $57.0 \%$ & $50.9 \%$ & $54.9 \%$ & $55.0 \%$ & $55.6 \%$ & $56.1 \%$ \\
\hline Silver Mill Recovery & y $\quad \ldots$ & -. & -. & . & . & $53 \%$ & $66.9 \%$ & $70 \%$ \\
\hline (million ounces) & -. & - & -. & - & $\cdots$ & 3.615 & 4.304 & 4.273 \\
\hline $\begin{array}{l}\text { Total } \\
\text { concentrate (tons) }^{b}\end{array}$ & 443,600 & 521,400 & 474,900 & 539,800 & 658,000 & 753,600 & 765,300 & 799,400 \\
\hline Employees & 350 & 331 & 349 & $376^{\mathrm{a}}$ & 311 & 397 & 417 & 478 \\
\hline
\end{tabular}




\section{WESTERN REGION}

\section{Metals}

Two hardrock gold mines and 22 placer gold mines in the western region produced a total of 104,297 fine ounces of gold in 1997; 44,986 ounces of that total were placer gold.

Alaska Gold Co. continued open-pit placer gold mining of the submarine beach west of Nome (fig. 15), producing 28,200 ounces from 870,000 cubic yards of pay gravel. The mine employs 70 people, and is a typical open-pit operation. Some of the Alaska Gold Co. properties were leased to other operators.

About 40 miles south of Galena the Illinois Creek lode gold-silver mine poured its first gold in June. This mine is operated by Dakota Mining Corp., with a 5 percent net smelter interest held by Cook Inlet Region Inc., a Native corporation formed during land title settlements in 1971. Although most of the concerns voiced during permitting regarded whether the valleyfill leach would overflow, a near drought throughout the summer (and fires bigger than those in Indonesia) prevented Dakota Mining Corp. from sufficiently watering the heap. By September, the flow to the heap was at 90 percent of the predicted rate, and by year end 1.35 million tons of rock averaging 0.072 ounces of gold per ton was on the pad. Dakota produced about 20,111 ounces in 1997 , expects to produce about 80,000 ounces in 1998, and expects to average about 65,000 ounces per year for the next 5 years.

At the Nixon Fork gold-copper skarn mine near McGrath, Consolidated Nevada Goldfields produced 39,666 ounces of gold and 420 tons of copper in concentrates. The concentrates are flown out from the mine to Palmer for shipment to the Dallo Inc. smelter in Kosaka, Japan.

\section{Industrial Minerals}

Cape Nome Products, a new joint venture between Sound Quarry Inc. and Knik Construction, mined 30,000 tons of rock from the granitic orthogneiss quarry at Cape Nome east of the town of Nome.

\section{EASTERN INTERIOR REGION}

\section{Metals}

In addition to gold produced at the Fort Knox gold mine, 73 placer mines reported recovery of 57,453 fine ounces of gold in 1997 (fig. 16). Some of these, such as Polar Mining's Goldstream operation, Yellow Eagle Mining's Cripple Creek Joint Venture with Exploration Orbite V.S.P.A. Inc, and Alaska Placer Development's
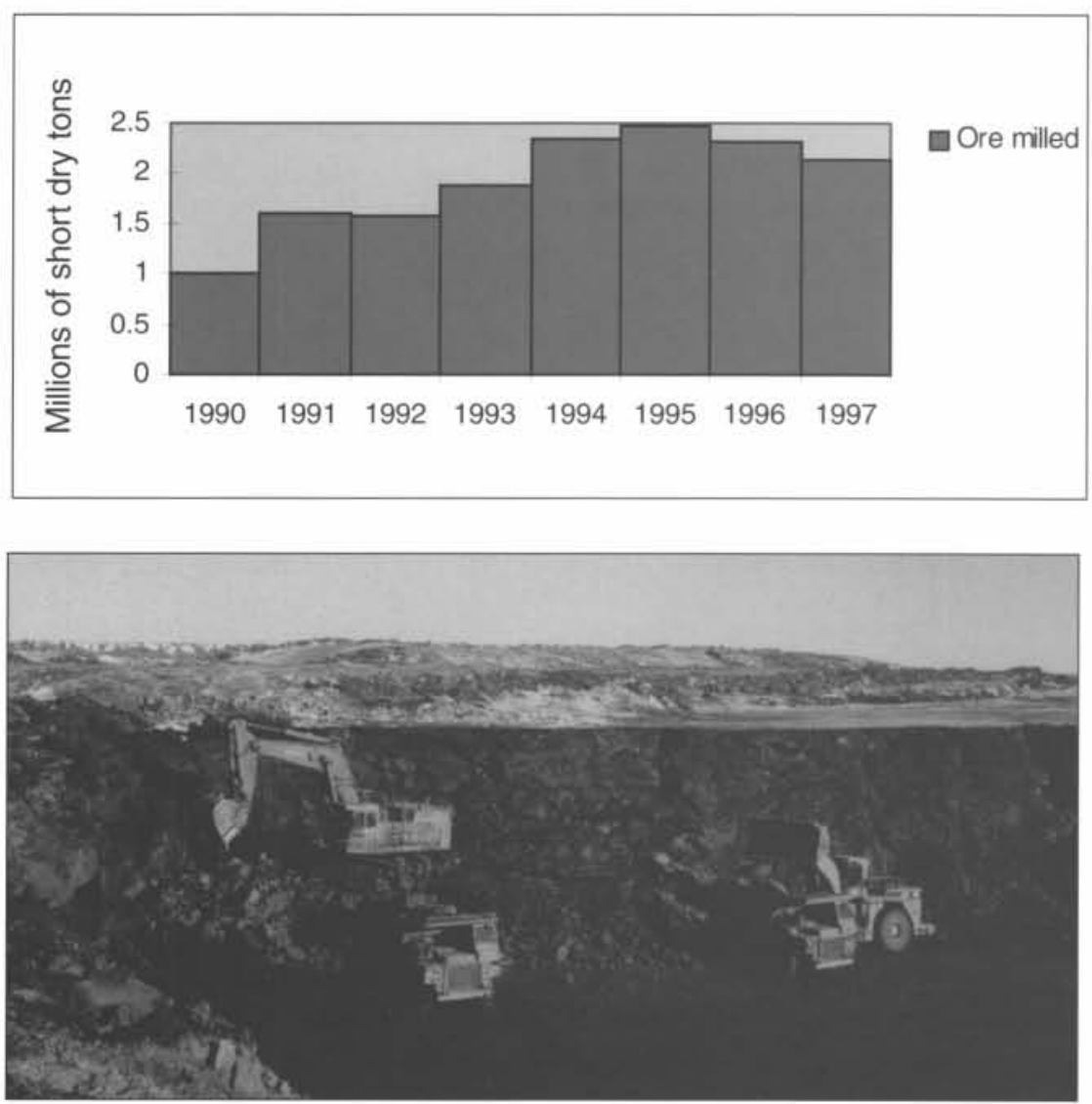

Figure 14. Ore milled annually at the Red Dog Mine, 1990-97.

Figure 15. Alaska Gold Co.'s winter pit, Airport block \#1. Photo by John Handeland. 
Livengood operation, are among the largest operations in the state. It is interesting to note that the only underground placer operations in the state are those of AU Mining in the Chatanika Valley near Cleary, north of Fairbanks, and the Little Eldorado Group's operation on the creek of the same name nearby.

With the commissioning of the Fort Knox open-pit hardrock gold mine about 15 miles northeast of Fairbanks, this region became the second most valuable region of the state in 1997. Operated by Fairbanks Gold Mining Inc., a wholly-owned subsidiary of Amax Gold Inc., the first official gold pour at the Fort Knox mine was on December 20, 1996, and the first commercial gold was produced in March 1997. Production through the end of December 1997, including 45,701 ounces of pre-commercial production prior to March 1, was 366,223 ounces, from $11,689,000$ tons grading 0.0343 ounces per ton. The cash cost per ounce was $\$ 170$, the total production cost was $\$ 342$, and the average selling price for all operations worldwide was $\$ 360$ per ounce. The 174-million-ton deposit is hosted by a 93million-year-old multi-phase granitic stock. Gold occurs within northwest-trending quartz vein stockwork associated with minor bismuth and tungsten, and trace sulfides.

\section{Coal and Peat}

Usibelli Coal Mine Inc. produced 1.446 million tons from its mine near Healy, and exported 650,000 tons to
Korea, with the remainder firing five interior Alaska power plants. One million tons was recovered from its Poker Flats lease, and the remainder from the Gold Run Pass lease. A new 50-megawatt clean coal power plant at the mine mouth has already added power to the Fairbanks-Anchorage intertie. The plant will be in a demonstration mode in 1998, in full production in 1999, and will use up to 300,000 tons of poorer quality coal that is presently discarded.

Peat was produced from pits on College Road in Fairbanks by Great Northwest Inc., and by Exclusive Landscaping \& Paving, Inc. from a pit in the Goldstream Valley near Fairbanks.

\section{Industrial Minerals}

Production of sand and gravel in the eastern interior region in 1997, 2.4 million tons, was down slightly from the 2.9 million tons used in 1996, as the number of road construction projects continue to decline.

Most of the gravel used in the construction of the Geist Road overpass west of Fairbanks was taken from nearby gravel pits, but some was derived from the washed and screened tailings from local placer mines, particularly Yellow Eagle's Cripple Creek operation.

Yutan Construction Co. produced basalt from its Browns Hill Quarry east of Fairbanks for various purposes, including road sanding by the Department of Transportation during the winter. A small amount of decorative stone was collected from the roadside bluffs at Shaw Creek, about 70 miles southeast of Fairbanks.

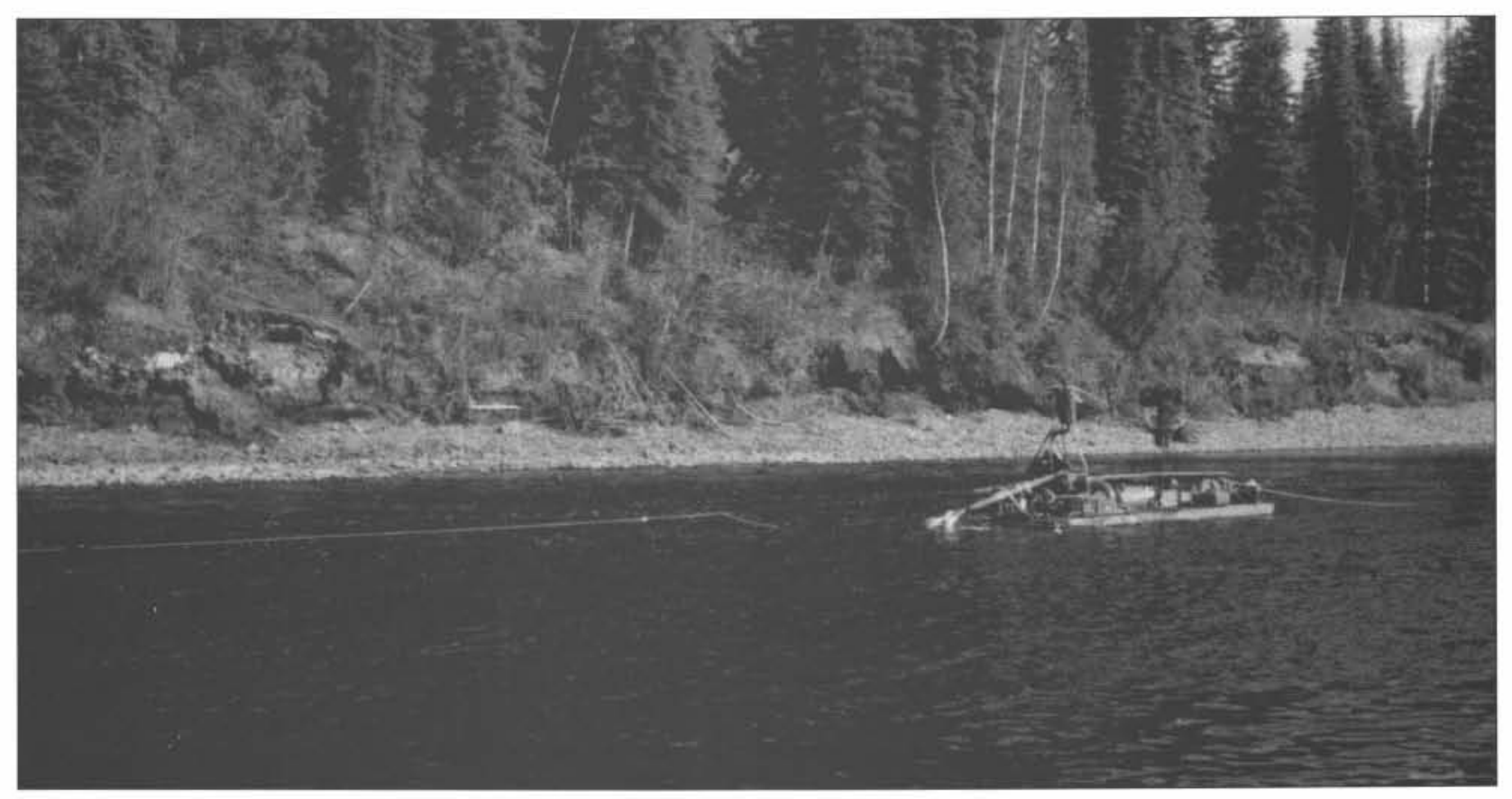

Figure 16. Roger Tallini's $8^{\prime \prime}$ suction dredge operation, 1997, South Fork Fortymile River. Photo by Roger Tallini. 


\section{SOUTHCENTRAL REGION}

\section{Metals}

The only metal production from this region in 1997 was from six small conventional placer operations, with a total yield of 971 fine ounces, valued at $\$ 321,168$.

\section{Coal and Peat}

Peat production for local horticultural use was reported by several operators in the Matanuska-Susitna Valley, including The Dirt Co. and Landscape Supply Co.

\section{Industrial Minerals}

Road construction projects on the Parks Highway near Houston, on the Glenn Highway east of Palmer, and on the Seward Highway along Turnagain Arm and at Moose Pass created a strong demand for both sand and gravel and rock products in 1997. Much of the material used was derived from the rights of way as cut-and-fill, but the 8.4 million tons of sand and gravel used in 1997 was more than double the 3.5 million tons used in 1996. This reflects a shift in recent years in road construction projects to the most populated region of the state.

Private contractors providing sand and gravel in this region include Hermon Brothers Construction Co. from its pit at 1.5 mile on the Palmer-Wasilla Highway; Harris Sand \& Gravel Inc. provided material in the Valdez area; Chugach Alaska Corp. mined substantial quantities for Cordova, and also in the MatSu Borough; Jackson Construction Co. reported production on the Kenai; and Pate Construction Inc. provided sand and gravel for the Yakutat area.

\section{SOUTHWESTERN REGION}

\section{Metals}

Metal production in this region in 1997 was an estimated 5,070 fine ounces of gold valued at \$1.68 million derived from 10 placer mines as shown in table 10 .

\section{Industrial Minerals}

A small amount of gravel and processed gravel was used by the State Department of Transportation \& Public Facilities for airport maintenance in this region in 1997.

\section{ALASKA PENINSULA REGION INDUSTRIal Minerals \\ Closure of the military facilities at King Salmon required most of the sand and gravel used in this region, as well as 120,000 cubic yards of silt for capping material. A small amount of sand and gravel was also used to complete reconstruction of the South Naknek airport. Hopkins Brothers Construction Co. provided shot rock at Seldovia for local use.}

\section{SOUTHEASTERN REGION}

\section{Metals}

Virtually all of the metal production in this region in 1997 was from the Greens Creek hardrock operation near Hawk Inlet on the west side of Admiralty Island west of Juneau (fig. 17).

The Greens Creek Mine (Kennecott 70.3 percent, Hecla Mining 29.7 percent) produced concentrates

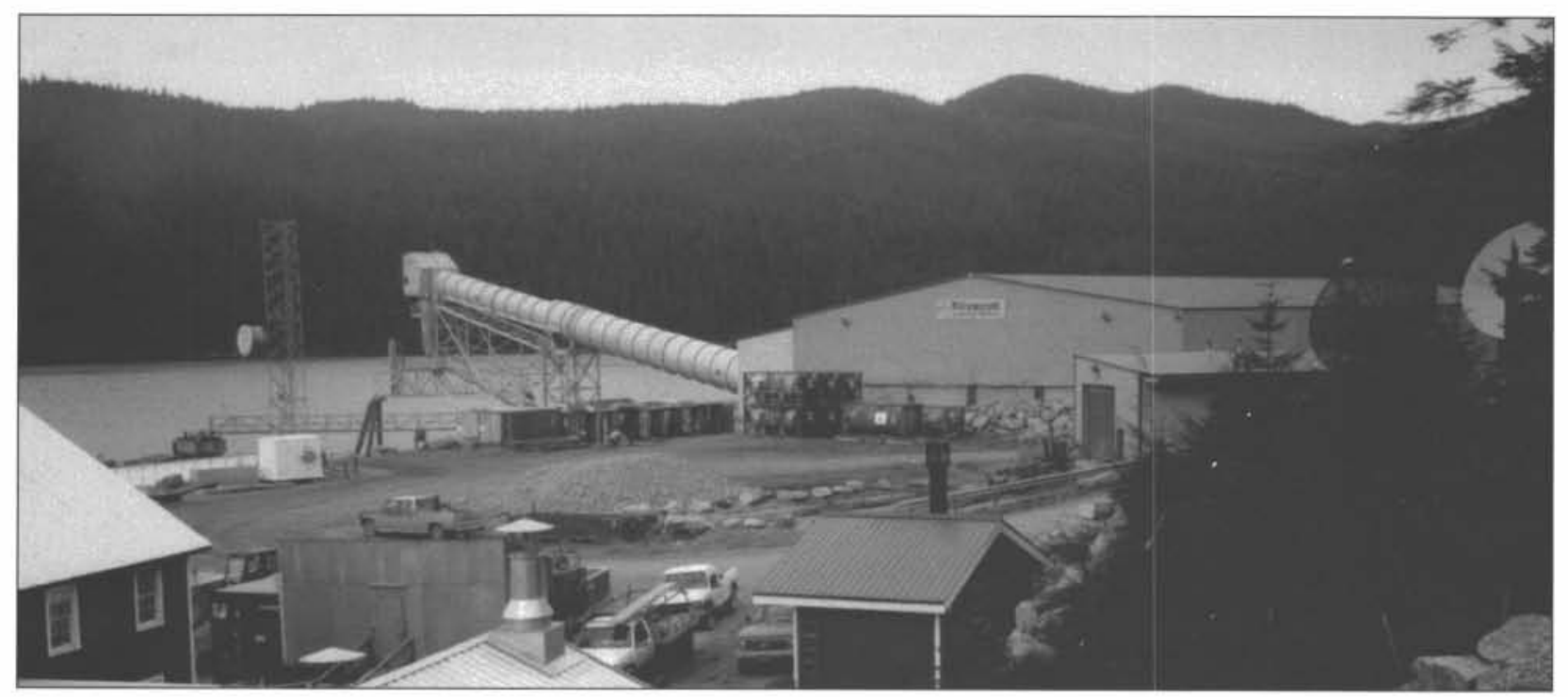

Figure 17. Load-out conveyor for the Greens Creek Mine at Hawk Inlet west of Juneau. Photo by Mitch Henning. 
containing payable 46,000 tons of zinc, 19,000 tons of lead, 56,000 ounces of gold, 9.7 million ounces of silver, and 1,300 tons of copper. Approximately 1,350 tons of ore are mined daily in two shifts using rubbertired, diesel-powered, 3- and 6-yard scoops to load 20and 40-ton trucks from a dozen active headings in the mine. The ore is trucked from the 920 level portal to the mill where, in a continuous-feed, electronicallymonitored process, it is crushed, ground, separated, and floated. The concentrate is segregated into a lead and zinc concentrate, and the gold is separated before the concentrate is dewatered. Tailings are either mixed with cement and recycled to the mine as backfill, or are stored in the dry tailings facility. Water is recycled to the water treatment facility.
Production was reported at two placer gold mines in Porcupine Creek near Haines.

\section{IndUSTRIAL Minerals}

The southeastern region was the major user of rock in the state in 1997 ( 3 million tons), with the majority being used for construction of the ferry terminal parking area near Juneau, and maintenance of logging roads throughout the Tongass National Forest. The City of Thorne Bay also reported using a small amount of shotrock for road work near the city.

Hildre Sand \& Gravel Co. produced sand and gravel from its Lemon Creek and Montana Creek Pits for local construction in the Juneau area.

\section{DRILLING}

Table 16 is a listing of companies with significant drill programs in 1997. Table 17 summarizes 1997 drilling activity by region of the state. Table 18 shows the historical trends of drilling since 1982. The total amount of drilling, 757,488 feet, compares well with the 729,137 feet drilled in the previous year. Placer exploration (fig. 18) continues to decline, although there is a renewed interest in coal, particularly in the high-rank fields of southcentral Alaska at Wishbone Hill. Core drilling continues to dominate hardrock exploration, though there is a regional preference, with reverse-circulation drilling favored in western and interior Alaska, while core drilling is used exclusively in southeastern Alaska where most of the 1997 drilling was underground.

Table 16. Companies reporting significant drilling programs in Alaska in 1997

\begin{tabular}{lll}
\hline Abacus Minerals Corp. & Grayd Resources Corp. & Silverado Gold Mines Ltd. \\
Alaska Gold Co. & Intercontinental Mining Corp. & Sumitomo Metal Mining Canada Ltd./ \\
Alaska Placer Development & International Freegold Mineral & Teck Corp. \\
American Copper \& Nickel Co. & Development Inc. & Sumitomo Coal Mining Co. Ltd./Nerox \\
ASA Inc. & Liberty Bell Mining Inc. & Power Systems Inc. \\
Cominco Alaska Inc. & Kennecott Exploration Inc. & Teck Corp. \\
Consolidated Nevada & Kennecott Greens Creek Mining Co. & Tri-Valley Corp. \\
$\quad$ Goldfields Inc. & Newmont Exploration Ltd. & Usibelli Coal Mine Inc. \\
Cross Canada International Inc. & Placer Dome Exploration Inc. & Ventures Resource Alaska Corp.
\end{tabular}

\section{Table 17. Drilling footage by region in Alaska, 1997}

\begin{tabular}{|c|c|c|c|c|c|c|c|c|}
\hline Type of drilling & Northern & Western & $\begin{array}{l}\text { Eastern } \\
\text { interior }\end{array}$ & $\begin{array}{l}\text { South- } \\
\text { central }\end{array}$ & $\begin{array}{l}\text { South- } \\
\text { western }\end{array}$ & $\begin{array}{c}\text { Alaska } \\
\text { Peninsula }\end{array}$ & $\begin{array}{l}\text { South- } \\
\text { eastern }\end{array}$ & TOTAL \\
\hline Placer exploration & 1,500 & 18,680 & 18,800 & $\ldots$ & -. & $\ldots$ & $\cdots$ & 38,980 \\
\hline Placer thawfield & - & - & $\ldots$ & - & - & - & $\ldots$ & .. \\
\hline Placer subtotal & 1,500 & 18,680 & 18,800 & -. & -. & - & -. & 38,980 \\
\hline Coal subtotal & . & . & 9,458 & 4,540 & -. & - & $\cdots$ & 13,998 \\
\hline Hardrock core & 59,036 & 68,353 & 143,743 & - & 83,544 & -. & 169,000 & $523,676^{a}$ \\
\hline Hardrock rotary & .. & 7,380 & 146,886 & - & 26,568 & $\cdots$ & - & 180,834 \\
\hline $\begin{array}{l}\text { Hardrock subtotal } \\
\text { TOTAL (feet) }\end{array}$ & $\begin{array}{l}59,036 \\
60,536\end{array}$ & $\begin{array}{l}\mathbf{7 5 , 7 3 3} \\
\mathbf{9 4 , 4 1 3}\end{array}$ & $\begin{array}{l}290,629 \\
318,887\end{array}$ & 4,540 & $\begin{array}{l}110,112 \\
110,112\end{array}$ & .. & $\begin{array}{l}169,000 \\
169,000\end{array}$ & $\begin{array}{l}704,510 \\
757,488\end{array}$ \\
\hline
\end{tabular}


Table 18. Drilling footage reported in Alaska, 1982-97

\begin{tabular}{|c|c|c|c|c|c|c|c|c|}
\hline Year & $\begin{array}{c}\text { Placer } \\
\text { Exploration }\end{array}$ & $\begin{array}{l}\text { Placer } \\
\text { Thawing }\end{array}$ & $\begin{array}{l}\text { TOTAL } \\
\text { PLACER }\end{array}$ & $\begin{array}{l}\text { TOTAL } \\
\text { COAL }\end{array}$ & $\begin{array}{c}\text { TOTAL } \\
\text { HARDROCK }\end{array}$ & $\begin{array}{c}\text { Hardrock } \\
\text { Core }^{a}\end{array}$ & $\begin{array}{l}\text { Hardrock } \\
\text { Rotary }^{\mathrm{a}}\end{array}$ & $\begin{array}{c}\text { TOTAL } \\
\text { FEET }\end{array}$ \\
\hline 1982 & 30,000 & 94,000 & 124,000 & 80,000 & 200,000 & - & -. & 404,000 \\
\hline 1983 & 23,000 & 30,000 & 53,000 & 12,000 & 180,500 & $\ldots$ & $\ldots$ & 245,500 \\
\hline 1984 & 31,000 & 98,000 & 129,000 & 25,700 & 176,000 & $\ldots$ & $\ldots$ & 330,700 \\
\hline 1985 & 46,000 & 34,000 & 80,000 & 8,700 & 131,700 & -. & .. & 220,400 \\
\hline 1986 & 32,400 & 227,000 & 259,400 & 28,800 & 50,200 & .. & . & 338,400 \\
\hline 1987 & 50,250 & 130,000 & 180,250 & 19,900 & 115,100 & 95,600 & 19,500 & 315,250 \\
\hline 1988 & 152,000 & 300,000 & 452,000 & 26,150 & 353,860 & 223,630 & 130,230 & 832,010 \\
\hline 1989 & 97,250 & 210,000 & 307,250 & 38,670 & 332,230 & 242,440 & 89,790 & 678,150 \\
\hline 1990 & 78,930 & 105,000 & 183,930 & 18,195 & 760,955 & 648,600 & 112,355 & 963,080 \\
\hline 1991 & 51,247 & 130,000 & 181,247 & 16,894 & 316,655 & 205,805 & 110,850 & 514,796 \\
\hline 1992 & 6,740 & 65,000 & 71,740 & 12,875 & 359,834 & 211,812 & 148,022 & 444,449 \\
\hline 1993 & 25,216 & -. & 25,216 & . & 252,315 & 124,325 & 127,990 & 277,531 \\
\hline 1994 & 21,000 & -. & 21,000 & 8,168 & 438,710 & 347,018 & 91,692 & 467,878 \\
\hline 1995 & 27,570 & -. & 27,570 & .. & 415,485 & 363,690 & 51,795 & 443,055 \\
\hline 1996 & 61,780 & -. & 61,780 & 8,500 & 658,857 & 524,330 & 134,527 & 729,137 \\
\hline 1997 & 38,980 & $\ldots$ & 38,980 & 13,998 & 704,510 & $523,676^{\mathrm{b}}$ & 180,834 & 757,488 \\
\hline
\end{tabular}

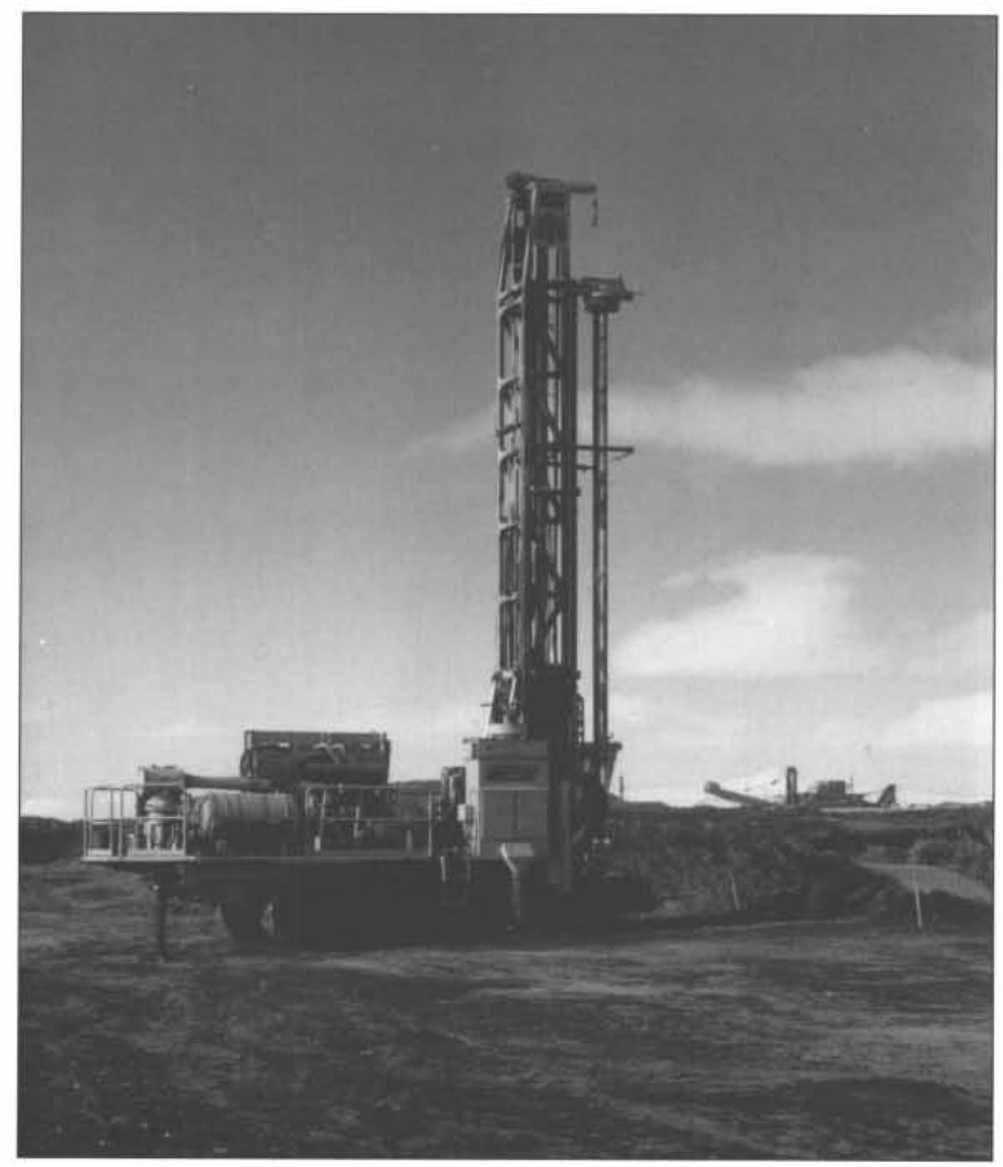

Figure 18, Drilling at Alaska Gold Co,'s

Submarine Pit. Photo by John Handeland. 


\section{GOVERNMENT ACTIONS}

During 1997 the Division of Geological \& Geophysical Surveys (DGGS) released new geophysical surveys in the historic mining regions of Rampart, Chulitna, and Petersville-Collinsville. New surveys were contracted and flown during 1997 near Iron Creek in the Talkeetna Mountains north of Anchorage, and south of Ruby on the Yukon River. The Iron Creek survey results were released in January 1998 and the Ruby survey in February 1998. The Division also worked with the U.S. Bureau of Land Management (BLM) to contract for airborne surveys near Wiseman in the Brooks Range. In an unusual arrangement BLM and the City of Wrangell sponsored a survey of several islands near the city in southeastern Alaska. The Wrangell surveys were released late in 1997 and the Wiseman survey was released early in 1998.

Table 19 shows the revenues derived from the mining industry by the State of Alaska and by municipalities.

There was continued progress in clarification of water quality standards for the state in 1997, and the U.S. Geological Survey, working with the Division of Mining \& Water Management, started long-term baseline studies of water quality in the Fortymile River drainage. The study includes differentiation of the total versus dissolved metals, metal speciation by valency, and lithogeochemical controls. It is hoped that these data will allow for more flexible permit conditions in the future.

Access to mineralized areas, especially across conservation systems units such as national parks or refuges, continues to be a State priority, and assertions of rights-of-way continue.

The appeal by some of the Mental Health Land Trust plaintiffs was denied by the State Supreme Court in 1997, leading to a final settlement of this contentious legal battle. The result is that the lands can now be offered for mineral leasing.

The Governor's 1997 award for mined land reclamation was given to Ed Salter of Manley for his

Table 19. Revenues paid to the State of Alaska and municipalities by Alaska's mineral industry, 1992-97a

\begin{tabular}{|c|c|c|c|c|c|c|}
\hline & 1992 & 1993 & 1994 & 1995 & 1996 & 1997 \\
\hline \multicolumn{7}{|l|}{$\begin{array}{l}\text { State mineral rents } \\
\text { and royalties }\end{array}$} \\
\hline State claim rentals & 537,355 & $\$ 523,661$ & $\$ 709,568$ & $\$ 712,559$ & 929,744 & $\$ 1,115,591$ \\
\hline Production royalties & 7,815 & 7,917 & 12,015 & 6,762 & 6,208 & 8,358 \\
\hline Mining license & 465,153 & 425,607 & 481,907 & 484,035 & 481,000 & $1,900,000$ \\
\hline Annual labor & $\ldots$ & $\ldots$ & .. & $\ldots$ & 62,900 & 89,500 \\
\hline Subtotal & $1,010,323$ & 957,185 & $1,203,490$ & $1,203,356$ & $1,479,852$ & $3,113,449$ \\
\hline \multicolumn{7}{|l|}{$\begin{array}{l}\text { State coal rents } \\
\text { and royalties }\end{array}$} \\
\hline Royalties & $1,294,825$ & $1,486,100$ & $1,399,912$ & $1,866,952$ & $1,348,841$ & $1,250,000$ \\
\hline Rents & 198,835 & 198,835 & 198,835 & 172,024 & 206,515 & 205,500 \\
\hline Subtotal & $1,493,660$ & $1,684,935$ & $1,598,747$ & $2,038,976$ & $1,555,356$ & $1,455,500$ \\
\hline \multicolumn{7}{|l|}{ State material sales } \\
\hline Mental Health & 104,845 & 5,300 & 54,772 & 106,505 & 126,000 & 299,000 \\
\hline Division of Land & 491,235 & 561,414 & 174,484 & 351,094 & 431,815 & 403,169 \\
\hline SPCO & 161,408 & 150,000 & 136,752 & 115,744 & 44,403 & 30,110 \\
\hline School fund & 3,279 & 3,011 & 1,564 & 8,812 & N/A & N/A \\
\hline Subtotal & 760,767 & 719,725 & 367,572 & 582,155 & 602,218 & 732,279 \\
\hline State total & $3,264,750$ & $3,361,845$ & $3,169,809$ & $3,824,487$ & $3,637,426$ & $5,301,228$ \\
\hline Payments to & & & & & & \\
\hline Municipalities & N/A & N/A & N/A & N/A & N/A & $8,386,000$ \\
\hline TOTAL & $\$ 3,264,750$ & $\$ 3,361,845$ & $\$ 3,169,809$ & $\$ 3,824,487$ & $\$ 3,637,426$ & $\$ 13,687,228$ \\
\hline
\end{tabular}


work on Doric Creek, a tributary of Pioneer Creek near Eureka in the Manley Hot Springs district. Awards were also presented to Marc Poage for work on Crooked Creek at Central, to Morris Wolters of Cathlament, Washington, for his work on Crooked Creek, and to Ryan Lode Mines of Fairbanks. The prestigious "Health of the Land Award" was presented to Cambior USA Inc. by Patrick Shea, director of the U.S. Bureau of Land Management, for the exemplary reclamation of the Valdez Creek placer mine.

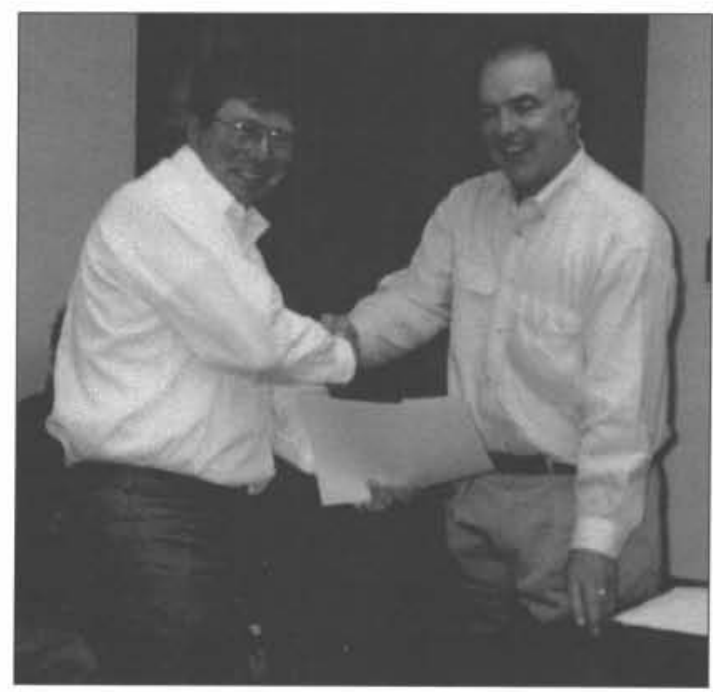

Figure 19. Tom Bundtzen receives an award from DNR Commissioner John Shively for 25 years of service in the Division of Geological \& Geophysical Surveys shortly before his retirement in August 1997. Photo by Dick Swainbank.
Two long-term authors of these reports resigned in 1997. Thomas K. (Tom) Bundtzen received an award for 25 years of service to DGGS in July, and retired in August, to consult to the industry as Pacific Rim Geological Consulting (fig. 19). Albert H. (AI) Clough resigned from the Division of Trade \& Development in August and joined Kvaerner Environmental in August 1997 to help in the closure of the Alaska-Juneau Mine (fig. 20).

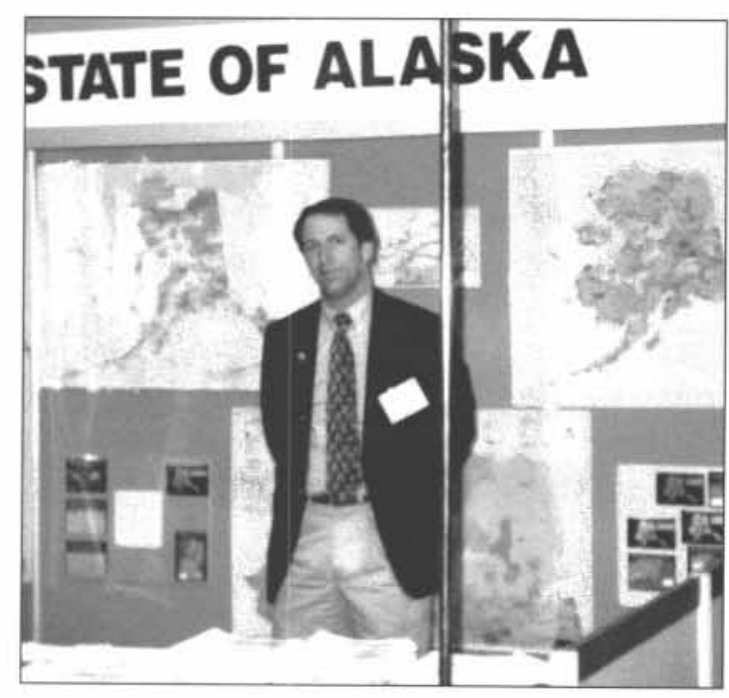

Figure 20. Al Clough at the State of Alaska trade booth at the Prospectors \& Development Association of Canada, March 1997. Photo by Dick Swainbank. 


\section{APPENDIX A}

\section{New claims staked in Alaska 1993-1997}

\begin{tabular}{|c|c|c|c|c|c|c|c|c|c|c|c|}
\hline \multirow{2}{*}{$\begin{array}{r}\text { Quad } \\
\text { no. }\end{array}$} & \multirow{2}{*}{$\begin{array}{c}\text { Quadrangle } \\
\text { name }\end{array}$} & \multicolumn{5}{|c|}{ New federal mining claims } & \multicolumn{5}{|c|}{ New state mining claims } \\
\hline & & 1993 & 1994 & 1995 & 1996 & 1997 & 1993 & 1994 & 1995 & 1996 & 1997 \\
\hline 17 & Point Hope & 0 & 0 & 0 & 0 & 0 & 0 & 0 & 0 & 43 & 0 \\
\hline 18 & De Long Mountains & 0 & 0 & 0 & 0 & 0 & 0 & 144 & 28 & 0 & 0 \\
\hline 23 & Philip Smith Mountains & 0 & 0 & 0 & 0 & 0 & 0 & 0 & 0 & 0 & 0 \\
\hline 26 & Noatak & 0 & 0 & 0 & 0 & 0 & 0 & 0 & 61 & 634 & 96 \\
\hline 27 & Baird Mountains & 0 & 0 & 1 & 0 & 1 & 0 & 0 & 18 & 1 & 0 \\
\hline 28 & Ambler River & 0 & 0 & 0 & 0 & 0 & 5 & 189 & 95 & 0 & 1,333 \\
\hline 29 & Survey Pass & 0 & 0 & 0 & 0 & 0 & 0 & 0 & 0 & 0 & 722 \\
\hline 30 & Wiseman & 278 & 39 & 20 & 0 & 47 & 5 & 55 & 34 & 6 & 44 \\
\hline 31 & Chandalar & 9 & 9 & 12 & 3 & 17 & 16 & 21 & 502 & 118 & 75 \\
\hline 32 & Christian & 0 & 0 & 0 & 0 & 0 & 0 & 0 & 0 & 0 & 0 \\
\hline 35 & Kotzebue & 0 & 0 & 0 & 0 & 0 & 15 & 0 & 4 & 0 & 28 \\
\hline 37 & Shungnak & 0 & 0 & 0 & 0 & 0 & 0 & 0 & 0 & 0 & 0 \\
\hline 38 & Hughes & 0 & 0 & 0 & 0 & 0 & 0 & 0 & 0 & 0 & 72 \\
\hline 39 & Bettles & 10 & 15 & 7 & 0 & 56 & 0 & 6 & 4 & 0 & 0 \\
\hline 43 & Teller & 0 & 0 & 0 & 0 & 0 & 0 & 0 & 42 & 0 & \\
\hline 44 & Bendeleben & 0 & 0 & 0 & 0 & 0 & 13 & 4 & 31 & 55 & 67 \\
\hline 45 & Candle & 0 & 0 & 0 & 0 & 0 & 4 & 11 & 21 & 16 & 201 \\
\hline 47 & Melozitna & 0 & 0 & 0 & 0 & 0 & 24 & 6 & 4 & 4 & 0 \\
\hline 48 & Tanana & 0 & 0 & 0 & 0 & 0 & 70 & 177 & 53 & 76 & 99 \\
\hline 49 & Livengood & 33 & 0 & 0 & 0 & 1 & 153 & 146 & 545 & 1,838 & 352 \\
\hline 50 & Circle & 0 & 0 & 0 & 0 & 0 & 477 & 256 & 413 & 100 & 658 \\
\hline 51 & Charley River & 0 & 0 & 0 & 0 & 0 & 0 & 0 & 0 & 0 & 0 \\
\hline 52 & Nome & 4 & 0 & 0 & 0 & 0 & 11 & 43 & 168 & 195 & 78 \\
\hline 53 & Solomon & 0 & 0 & 0 & 0 & 0 & 8 & 56 & 39 & 31 & 29 \\
\hline 54 & Norton Bay & 0 & 0 & 0 & 0 & 0 & 0 & 0 & 25 & 0 & 0 \\
\hline 55 & Nulato & 0 & 0 & 0 & 0 & 0 & 5 & 0 & 0 & 0 & 0 \\
\hline 56 & Ruby & 0 & 0 & 0 & 0 & 0 & 27 & 29 & 12 & 405 & 200 \\
\hline 57 & Kantishna River & 0 & 0 & 0 & 0 & 1 & 0 & 0 & 14 & 0 & 0 \\
\hline 58 & Fairbanks & 0 & 0 & 0 & 0 & 0 & 195 & 143 & 364 & 360 & 546 \\
\hline 59 & Big Delta & 0 & 0 & 0 & 0 & 0 & 213 & 408 & 421 & 637 & 1,010 \\
\hline 60 & Eagle & 0 & 0 & 0 & 0 & 0 & 170 & 171 & 116 & 122 & 171 \\
\hline 64 & Ophir & 0 & 0 & 0 & 0 & 0 & 15 & 109 & 8 & 13 & 47 \\
\hline 65 & Medfra & 0 & 0 & 0 & 0 & 0 & 2 & 30 & 0 & 0 & 128 \\
\hline 66 & Mt. McKinley & 0 & 0 & 0 & 0 & 0 & 2 & 0 & 0 & 0 & 0 \\
\hline 67 & Healy & 0 & 0 & 0 & 0 & 0 & 90 & 195 & 335 & 80 & 388 \\
\hline 68 & Mt. Hayes & 0 & 12 & 171 & 124 & 772 & 80 & 163 & 858 & 622 & 1,185 \\
\hline 69 & Tanacross & 0 & 0 & 0 & 0 & 0 & 14 & 18 & 69 & 236 & 112 \\
\hline 72 & Holy Cross & 0 & 0 & 0 & 0 & 0 & 0 & 0 & 0 & 0 & 0 \\
\hline 73 & Iditarod & 6 & 0 & 0 & 70 & 0 & 0 & 13 & 223 & 414 & 296 \\
\hline 74 & McGrath & 0 & 0 & 0 & 0 & 0 & 0 & 0 & 0 & 0 & 0 \\
\hline 75 & Talkeetna & 0 & 0 & 3 & 0 & 0 & 68 & 120 & 48 & 129 & 117 \\
\hline 76 & Talkeetna Mountains & 0 & 0 & 0 & 0 & 4 & 61 & 45 & 48 & 234 & 50 \\
\hline 77 & Gulkana & 0 & 0 & 0 & 0 & 0 & 2 & 0 & 0 & 0 & 192 \\
\hline 78 & Nabesna & 0 & 0 & 0 & 0 & 0 & 0 & 0 & 0 & 0 & 2 \\
\hline 81 & Russian Mission & 0 & 0 & 0 & 0 & 0 & 0 & 0 & 0 & 0 & 0 \\
\hline 82 & Sleetmute & 0 & 0 & 0 & 0 & 0 & 0 & 8 & 22 & 0 & 0 \\
\hline 83 & Lime Hills & 0 & 0 & 0 & 0 & 0 & 0 & 2 & 8 & 2 & 238 \\
\hline 84 & Tyonek & 0 & 0 & 0 & 0 & 0 & 67 & 0 & 8 & 0 & 10 \\
\hline 85 & Anchorage & 0 & 3 & 0 & 0 & 0 & 64 & 56 & 79 & 18 & 97 \\
\hline 86 & Valdez & 0 & 0 & 0 & 0 & 0 & 0 & 2 & 20 & 11 & 8 \\
\hline 87 & McCarthy & 0 & 0 & 0 & 0 & 0 & 0 & 0 & 0 & 0 & 0 \\
\hline 91 & Bethel & 0 & 0 & 0 & 0 & 0 & 4 & 1 & 0 & 0 & 98 \\
\hline 92 & Taylor Mountains & 0 & 0 & 0 & 0 & 0 & 0 & 0 & 5 & 0 & 142 \\
\hline 93 & & 0 & 0 & 0 & 0 & 0 & 0 & 66 & 0 & 0 & \\
\hline
\end{tabular}




\begin{tabular}{|c|c|c|c|c|c|c|c|c|c|c|c|}
\hline \multirow{2}{*}{$\begin{array}{c}\text { Quad } \\
\text { no. }\end{array}$} & \multirow{2}{*}{$\begin{array}{l}\text { Quadrangle } \\
\text { name }\end{array}$} & \multicolumn{5}{|c|}{ New federal mining claims } & \multicolumn{5}{|c|}{ New state mining claims } \\
\hline & & 1993 & 1994 & 1995 & 1996 & 1997 & 1993 & 1994 & 1995 & 1996 & 1997 \\
\hline 94 & Kenai & 0 & 0 & 0 & 0 & 0 & 0 & 0 & 0 & 0 & 0 \\
\hline 95 & Seward & 95 & 51 & 58 & 0 & 108 & 13 & 32 & 21 & 23 & 26 \\
\hline 96 & Cordova & 0 & 0 & 0 & 0 & 1 & 0 & 0 & 0 & 0 & 0 \\
\hline 97 & Bering Glacier & 0 & 0 & 0 & 0 & 0 & 0 & 1 & 0 & 2 & 3 \\
\hline 102 & Dillingham & 0 & 0 & 0 & 0 & 0 & 0 & 219 & 4 & 7 & 32 \\
\hline 103 & Iliamna & 0 & 0 & 0 & 0 & 0 & 0 & 0 & 1 & 1 & 325 \\
\hline 104 & Seldovia & 0 & 0 & 0 & 0 & 0 & 0 & 2 & 0 & 0 & 0 \\
\hline 107 & Icy Bay & 0 & 0 & 0 & 0 & 0 & 14 & 0 & 0 & 0 & 3 \\
\hline 108 & Yakutat & 0 & 0 & 0 & 0 & 0 & 0 & 0 & 0 & 0 & 0 \\
\hline 109 & Skagway & 1 & 1 & 2 & 0 & 4 & 99 & 318 & 36 & 8 & 5 \\
\hline 111 & Mt. Fairweather & 0 & 0 & 0 & 0 & 0 & 0 & 0 & 0 & 0 & 0 \\
\hline 112 & Juneau & 76 & 27 & 63 & 199 & 263 & 20 & 3 & 10 & 20 & 2 \\
\hline 114 & Sitka & 8 & 39 & 2 & 0 & 7 & 0 & 0 & 2 & 0 & 0 \\
\hline 115 & Sumdum & 0 & 0 & 0 & 0 & 0 & 0 & 0 & 0 & 0 & 0 \\
\hline 116 & Port Alexander & 0 & 1 & 0 & 0 & 0 & 0 & 0 & 0 & 0 & 0 \\
\hline 117 & Petersburg & 19 & 1 & 23 & 267 & 485 & 0 & 0 & 0 & 0 & 0 \\
\hline 118 & Bradfield Canal & 0 & 0 & 0 & 0 & 0 & 0 & 0 & 0 & 0 & 0 \\
\hline 119 & Craig & 62 & 89 & 14 & 18 & 101 & 8 & 1 & 0 & 48 & 0 \\
\hline 120 & Ketchikan & 0 & 0 & 0 & 0 & 2 & 0 & 0 & 0 & 0 & 0 \\
\hline 121 & Dixon Entrance & 0 & 9 & 0 & 0 & 1 & 0 & 2 & 0 & 0 & 0 \\
\hline 123 & Hagemeister Island & 0 & 0 & 0 & 0 & 0 & 0 & 0 & 0 & 0 & 0 \\
\hline 127 & Afognak & 0 & 45 & 0 & 0 & 0 & 0 & 0 & 32 & 0 & 0 \\
\hline 133 & Chignik & 0 & 0 & 0 & 0 & 0 & 0 & 0 & 0 & 0 & 0 \\
\hline 135 & Trinity Islands & 0 & 0 & 0 & 0 & 0 & 8 & 1 & 38 & 35 & 5 \\
\hline 138 & Port Moller & 0 & 0 & 0 & 0 & 0 & 0 & 93 & 0 & 0 & 0 \\
\hline & TOTALS & 601 & 341 & 376 & 681 & 1,871 & 2,042 & 3,365 & 4,889 & 6,544 & 9,292 \\
\hline
\end{tabular}

Source: State of Alaska Division of Mining \& Water Management Kardex file. 
APPENDIX B

Prospecting sites in Alaska 1993-1997

\begin{tabular}{|c|c|c|c|c|c|c|c|c|c|c|c|c|c|c|c|c|}
\hline $\begin{array}{c}\text { Quad } \\
\text { no. }\end{array}$ & Quad name & $\begin{array}{l}1993 \\
\text { New }\end{array}$ & $\begin{array}{c}1993 \\
\text { Extended }\end{array}$ & $\begin{array}{l}1993 \\
\text { Total }\end{array}$ & $\begin{array}{l}1994 \\
\text { New }\end{array}$ & 1994 & 1994 & $\begin{array}{l}1995 \\
\text { New }\end{array}$ & $\begin{array}{c}1995 \\
\text { Extended }\end{array}$ & $\begin{array}{l}1995 \\
\text { Total }\end{array}$ & $\begin{array}{l}1996 \\
\text { New }\end{array}$ & 1996 & 1996 & $\begin{array}{l}1997 \\
\text { New }\end{array}$ & $\begin{array}{c}1997 \\
\text { Extended }\end{array}$ & $\begin{array}{l}1997 \\
\text { Total }\end{array}$ \\
\hline 17 & Point Hope & 8 & 0 & 8 & 0 & 0 & $\mathbf{0}$ & 9 & 0 & 9 & 0 & 0 & 0 & 0 & 0 & 0 \\
\hline 19 & Misheguk Mts. & 0 & 0 & 0 & 1 & 0 & 1 & 0 & 0 & 0 & 0 & 0 & $\mathbf{0}$ & 0 & 0 & 0 \\
\hline 26 & Noatak & 0 & 0 & 0 & 0 & 0 & $\mathbf{0}$ & 16 & 0 & 16 & 32 & 0 & 32 & 0 & 0 & 0 \\
\hline 27 & Baird Mts. & 0 & 0 & 0 & 10 & 0 & 10 & 6 & 0 & 6 & 9 & 0 & 9 & 0 & 0 & 0 \\
\hline 30 & Wiseman & 8 & 3 & 11 & 7 & 8 & 15 & 10 & 0 & 10 & 61 & 0 & 61 & 10 & 5 & 15 \\
\hline 31 & Chandalar & 12 & 0 & 12 & 3 & 18 & 21 & 2 & 5 & 7 & 28 & 0 & 28 & 34 & 0 & 34 \\
\hline 44 & Bendeleben & 0 & 0 & 0 & 7 & 0 & 7 & 5 & 4 & 9 & 48 & 0 & 48 & 28 & 16 & 44 \\
\hline 45 & Candle & 0 & 0 & 0 & 0 & 0 & 0 & 5 & 0 & 5 & 8 & 0 & 8 & 91 & 0 & 91 \\
\hline 47 & Melozitna & 0 & 0 & 0 & 7 & 0 & 7 & 0 & 0 & 0 & 222 & 128 & 350 & 0 & 96 & 96 \\
\hline 48 & Tanana & 11 & 0 & 11 & 41 & 7 & 48 & 54 & 15 & 69 & 309 & 133 & 442 & 21 & 193 & 214 \\
\hline 49 & Livengood & 63 & 23 & 86 & 82 & 22 & 104 & 324 & 38 & 362 & 43 & 194 & 237 & 162 & 34 & 196 \\
\hline 50 & Circle & 626 & 93 & 719 & 113 & 444 & 557 & 169 & 85 & 254 & 136 & 166 & 302 & 189 & 110 & 299 \\
\hline 52 & Nome & 25 & 14 & 39 & 13 & 22 & 35 & 45 & 10 & 55 & 96 & 34 & 130 & 52 & 45 & 97 \\
\hline 53 & Solomon & 11 & 8 & 19 & 9 & 3 & 12 & 19 & 1 & 20 & 29 & 5 & 34 & 11 & 38 & 49 \\
\hline 55 & Nulato & 0 & 0 & 0 & 0 & 0 & 0 & 0 & 0 & 0 & 4 & 0 & 4 & 6 & 0 & 6 \\
\hline 56 & Ruby & 0 & 0 & 0 & 0 & 0 & 0 & 0 & 0 & 0 & 21 & 0 & 21 & 70 & 18 & 88 \\
\hline 57 & Kantishna River & 0 & 3 & 3 & 0 & 0 & 0 & 0 & 0 & 0 & 0 & 0 & 0 & 0 & 0 & 0 \\
\hline 58 & Fairbanks & 40 & 5 & 45 & 45 & 5 & 50 & 85 & 17 & 102 & 124 & 20 & 144 & 58 & 33 & 91 \\
\hline 59 & Big Delta & 124 & 46 & 170 & 46 & 23 & 69 & 45 & 33 & 78 & 102 & 42 & 144 & 286 & 16 & 302 \\
\hline 60 & Eagle & 31 & 1 & 32 & 21 & 12 & 33 & 34 & 7 & 41 & 48 & 11 & 59 & 67 & 48 & 115 \\
\hline 64 & Ophir & 0 & 0 & 0 & 2 & 0 & 2 & 0 & 0 & 0 & 0 & 0 & 0 & 33 & 0 & 33 \\
\hline 65 & Medfra & 8 & 0 & 8 & 0 & 8 & 8 & 3 & 0 & 3 & 16 & 0 & 16 & 28 & 8 & 36 \\
\hline 67 & Healy & 83 & 22 & 105 & 36 & 49 & 85 & 12 & 0 & 12 & 112 & 7 & 119 & 472 & 119 & 591 \\
\hline 68 & Mt. Hayes & 17 & 0 & 17 & 14 & 6 & 20 & 2 & 12 & 14 & 236 & 12 & 248 & 230 & 30 & 260 \\
\hline 69 & Tanacross & 17 & 7 & 24 & 169 & 16 & 185 & 6 & 166 & 172 & 68 & 0 & 68 & 38 & 15 & 53 \\
\hline 73 & Iditarod & 0 & 0 & 0 & 0 & 0 & 0 & 0 & 0 & 0 & 182 & 0 & 182 & 4 & 66 & 70 \\
\hline 74 & McGrath & 0 & 0 & 0 & 0 & 0 & 0 & 6 & 0 & 6 & 13 & 6 & 19 & 203 & 12 & 215 \\
\hline 75 & Talkeetna & 25 & 8 & 33 & 4 & 15 & 19 & 14 & 3 & 17 & 37 & 5 & 42 & 390 & 39 & 429 \\
\hline 76 & Talkeetna Mts. & 0 & 0 & 0 & 8 & 0 & 8 & 41 & 40 & 81 & 17 & 21 & 38 & 18 & 0 & 18 \\
\hline 77 & Gulkana & 0 & 0 & 0 & 0 & 0 & 0 & 0 & 0 & o & 0 & 0 & 0 & 8 & 0 & 8 \\
\hline 81 & Russian Mission & 0 & 0 & 0 & 0 & 0 & 0 & 0 & 0 & 0 & 0 & 0 & 0 & 45 & 0 & 45 \\
\hline 82 & Sleetmute & 0 & 0 & 0 & 0 & 0 & 0 & 0 & 0 & 0 & 0 & 0 & 0 & 46 & 0 & 46 \\
\hline 83 & Lime Hills & 6 & 0 & 6 & 2 & 0 & 2 & 0 & 0 & 0 & 0 & 0 & 0 & 5 & 0 & 5 \\
\hline
\end{tabular}




\section{APPENDIX B}

Prospecting sites in Alaska 1993-1997

(continued)

\begin{tabular}{|c|c|c|c|c|c|c|c|c|c|c|c|c|c|c|c|c|}
\hline Quad \# & Quad name & $\begin{array}{l}1993 \\
\text { New }\end{array}$ & $\begin{array}{c}1993 \\
\text { Extend }\end{array}$ & $\begin{array}{l}1993 \\
\text { Total }\end{array}$ & $\begin{array}{l}1994 \\
\text { New }\end{array}$ & $\begin{array}{c}1994 \\
\text { Extend }\end{array}$ & $\begin{array}{l}1994 \\
\text { Total }\end{array}$ & $\begin{array}{l}1995 \\
\text { New }\end{array}$ & $\begin{array}{c}1995 \\
\text { Extend }\end{array}$ & $\begin{array}{l}1995 \\
\text { Total }\end{array}$ & $\begin{array}{l}1996 \\
\text { New }\end{array}$ & $\begin{array}{c}1996 \\
\text { Extend }\end{array}$ & $\begin{array}{l}1996 \\
\text { Total }\end{array}$ & $\begin{array}{l}1997 \\
\text { New }\end{array}$ & $\begin{array}{c}1997 \\
\text { Extend }\end{array}$ & $\begin{array}{l}1997 \\
\text { Total }\end{array}$ \\
\hline 84 & Tyonek & 18 & 0 & 18 & 6 & 18 & 24 & 0 & 0 & 0 & 0 & 0 & 0 & 6 & 14 & 20 \\
\hline 85 & Anchorage & 13 & 0 & 13 & 14 & 2 & 16 & 16 & 9 & 25 & 18 & 7 & 25 & 22 & 0 & 22 \\
\hline 86 & Valdez & 16 & 0 & 16 & 13 & 4 & 17 & 13 & 0 & 13 & 9 & 15 & 24 & 0 & 0 & $\mathbf{0}$ \\
\hline 91 & Bethel & 1 & 0 & 1 & 0 & 0 & 0 & 0 & 0 & 0 & 12 & 6 & 18 & 4 & 8 & 12 \\
\hline 92 & Taylor Mts. & 0 & 0 & 0 & 0 & 0 & 0 & 0 & 0 & 0 & 14 & 0 & 14 & 6 & 6 & 12 \\
\hline 94 & Kenai & 6 & 0 & 6 & 0 & 0 & $\mathbf{0}$ & 0 & 0 & 0 & 0 & 0 & 0 & 0 & 0 & 0 \\
\hline 95 & Seward & 4 & 0 & 4 & 0 & 0 & 0 & 1 & 0 & 1 & 73 & 40 & 113 & 2 & 24 & 26 \\
\hline 97 & Bering Glacier & 0 & 0 & 0 & 0 & 0 & 0 & 0 & 0 & 0 & 0 & 0 & 0 & 0 & 0 & $\mathbf{0}$ \\
\hline 102 & Dillingham & 0 & 0 & $\mathbf{0}$ & 0 & 0 & 0 & 0 & 0 & 0 & 0 & 0 & 0 & 48 & 0 & 48 \\
\hline 103 & Iliamna & 0 & 0 & 0 & 4 & 0 & 4 & 0 & 0 & 0 & 0 & 0 & 0 & 0 & 0 & 0 \\
\hline 104 & Seldovia & 0 & 0 & 0 & 0 & 0 & $\mathbf{0}$ & 0 & 0 & 0 & 1 & 0 & 1 & 0 & 0 & 0 \\
\hline 109 & Skagway & 36 & 0 & 36 & 8 & 16 & 24 & 0 & 0 & 0 & 13 & 0 & 13 & 6 & 0 & 6 \\
\hline 112 & Juneau & 5 & 0 & 5 & 0 & 0 & 0 & 0 & 0 & 0 & 0 & 0 & 0 & 0 & 0 & 0 \\
\hline 119 & Craig & 1 & 0 & 1 & 0 & 0 & 0 & 0 & 0 & 0 & 0 & 0 & 0 & 0 & 0 & 0 \\
\hline 120 & Ketchikan & 4 & 0 & 4 & 0 & 0 & 0 & 0 & 0 & 0 & 2 & 0 & 2 & 0 & 0 & 0 \\
\hline 135 & Trinity Islands & 3 & 0 & 3 & 25 & 0 & 25 & 1 & 2 & 3 & 14 & 0 & 14 & 0 & 0 & 0 \\
\hline & TOTALS & 1,222 & 233 & 1,455 & 710 & 698 & 1,408 & 943 & 447 & 1,390 & 2,157 & 852 & 3,009 & 2,699 & 993 & 3,692 \\
\hline
\end{tabular}

Source: State of Alaska Division of Mining \& Water Management Kardex file. 


\section{APPENDIX C}

\section{Mining licenses issued by and received from the Alaska Department of Revenue, 1997}

Entries include in this order: company name (region), address, resource, site of operation, mining district, and license number. Alaska Peninsula Region (APR), Eastern Interior Region (EIR), Northern Region (NR), Southcentral Region (SCR), Southwestern Region (SWR), Southeastern Region (SER), Undistributed (UR), Western Region (WR), and not given (NG).

A \& L Mining (WR)
PO Box 1974
Nome, AK 99762
Gold-Silver
Coffee Creek
Cape Nome district
ML 9067

Ackels, Del (NR)
PO 61520
Fairbanks, AK $99706-1520$
Gold-Silver
Big Creek
Chandalar district
ML 9036

Administrative Services (EIR) PO Box 70495

Fairbanks, AK 99707-0495

Mineral

Ketchum Creek

Circle district

ML 9151

\section{AG Mining (SWR) \\ PO Box 106 \\ McGrath, AK 99627-0106 \\ Gold-Silver \\ Dodge Creek \\ Innoko district \\ ML 5706

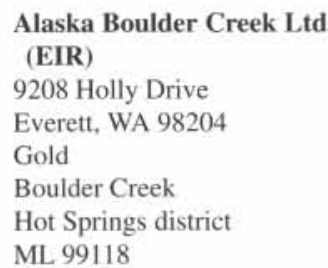

\section{Alaska Gold Company (WR) \\ PO Box 640 \\ Nome, AK 99762 \\ Gold-Silver \\ Third Beach/Dry Creek \\ Cape Nome district \\ ML 5821}

Alaska Gold Company (WR)

PO Box 640

Nome, AK 99762

Gold-Silver

Cape Nome district

ML 9393

\section{Alaska/Nevada Gold Mines \\ Ltd. (EIR)}

626 2nd St., Suite 202

\section{Fairbanks, AK 99701 \\ Gold-Silver \\ Livengood Creek \\ Livengood-Tolovana district \\ ML 7226}

Aldridge, William (NG)
PO Box 1334
Palmer, AK 99645
Gold-Silver
Poker Creek
Unknown district
ML 4399

AM Mining Ltd. (EIR)

PO Box 10263

Fairbanks, AK 99710-0263

Gold-Silver

Dome Creek APMA \#9135

Fairbanks district

ML 99112

\section{American Copper \& \\ Nickel Co. (EIR) \\ One New York Plaza \\ New York, NY 10004 \\ Base Metals \\ Alaska Range \\ ML 9119}

Anchorage Sand \& Gravel Co.

Inc. (SCR)

1040 O'Malley Rd.

Anchorage, AK 99515

Gravel

Anchorage district

ML 99028

Anderson \& Son Mining

(SWR)

Allan Anderson

PO Box 277

McGrath, AK 99627-0277

Gold-Silver

Yankee Creek

Innoko district

ML 6205

Angell, William R. (EIR)

417 Glacier Ave.

Fairbanks, AK 99701

Gold-Silver

Fortymile River

Fortymile district

ML 9381

Applebee, Robert (WR)

4111 E. 65 th Ave.

Anchorage, AK 99507
Gold

Bear Creek

Fairhaven district

ML 5167

Arctic Mining (EIR)

PO Box 30144

Central, AK 99730

Gold-Silver

Crooked Creek

Circle district

ML 5888

Arctic Whitney Inc.

(WR)

PO Box 782

Nome, AK 99762

Gold-Silver

Norton Sound

Cape Nome district

ML 9451

AU Mining Co. (WR)

PO Box 292

Willow, AK 99688

Gold-Silver

Candle Creek

Candle district

ML 5853

AU Mining Co. (WR)

PO Box 292

Willow, AK 99688

Gold-Silver

Mud Creek

Candle district

ML 7388

Barron, Dennis (WR)

PO Box 923

Nome, AK 99762

Gold-Silver

Goose and Quartz creeks

Fairhaven district

ML 9475

Bauer, Tod

PO Box 871502

Wasilla, AK 99687

Gold-Silver

Eldorado Creek

Unknown district

ML 6191

Bayless, Bill (EIR)

Drawer F

Copper Center, AK 99573

Gold-Silver

Franklin Street
Fortymile district

ML 9088

Beistline, Earl H.

(EIR)

PO Box 80148

Fairbanks, AK 99708-0148

Gold-Silver

Eagle and Cripple creeks

Circle district

ML 7106

Bergman, Kevin (EIR)

PO Box 71488

Fairbanks, AK 99707

Gold-Silver

Ester Creek

Fairbanks district

ML 9402

Bering Straits Native Corp.

(WR)

PO Box 1008

Nome, AK 99762

Gold-Silver

Nome River

Cape Nome district

ML 99125

Bering Straits Native Corp.

(WR)

PO Box 1008

Nome. AK 99762

Gold-Silver

Hastings Creek

Cape Nome district

ML 99005

Bering Straits Native Corp.

(WR)

PO Box 1008

Nome, AK 99762

Gravel

Beam Road

Cape Nome district

ML 99123

Bering Straits Native Corp.

(WR)

PO Box 1008

Nome, AK 99762

Gravel

Unalakleet

Anvik district

ML 99122

Berry Enterprises (EIR)

1101 Barnette St.

Fairbanks, AK 99701 


\author{
Gold-Silver \\ Ketchum Creek \\ Circle district \\ ML 99084
}

Bickell, D. Harvey (EIR)

PO Box 1026

Dawson City, YT Y0B IG0

Gold-Silver

Near Walker Fork

Fortymile district

ML 9356

Blue Ribbon Inc. (SCR)

PO Box 871906

Wasilla, AK 99688

Gold

Tributary of Cottonwood Creek

Yentna-Cache Creek district

ML 99082

Boehne, Roland L.

205 E. Dimond Blvd. \#451

Anchorage, AK 99515

Gold-Silver

Red Creek

Unknown district

ML 5657

Botnan, Ted R. (EIR)

9950 Stephen Richards Dr.

Juneau, AK 99801

Gold

Treasure Creek

Fairbanks district

ML 5951

Bracale, Carl. A. Jr. (NG)

PO Box 858

Gig Harbor, WA 98335

Gold-Silver

Camp Creek

Unknown district

ML 7302

Bradley, Joe

529 Lynwood

Anchorage, AK 99518

Gold-Silver

Skookum

Unknown district

ML 99116

Bras, Cy (EIR)

703 Swires Rd.

Kenai, AK 99611

Gold-Silver

Canyon Creek

Fortymile district

ML 9004

Burns, John R. (EIR)

PO Box 5

Chicken, AK 99732-0005

Gold-Silver

Davis Creek

Fortymile district

ML 4419
Byrd, Paul (EIR)

11192 Highway 37

Hibbing, MN 55746

Gold-Silver

Fortymile River

Fortymile district

ML 9452

Carlo \& Sons Mining Co.

(EIR)

2113 Southern Ave.

Fairbanks. AK 99709

Gold-Silver

Hunter Creek

Rampart district

ML. 7122

Carr, Brad (EIR)

PO Box 25

Chicken, AK 99732-0025

Gold-Silver

Fortymile River

Fortymile district

ML 99119

Cassiterite Placers Inc. (EIR)

413 Cowles St.

Fairbanks, AK 99701

Gold-Silver

Cache, Sullivan, Quartz, and

Tofty creeks

Hot Springs district

ML 7399

Caswell, James W. (SCR)

PO Box 196

Cantwell, AK 99729

Limestone

Valdez Creek district

ML 7437

Catt, Bruce D. \& Barbara

(EIR)

PO Box 45

Central, AK 99730

Gold-Silver

Crooked Creek

Circle district

ML 9310

Chase, Ernest M. (SWR)

PO Box 141

Aniak, AK 99588

Gold-Silver

Flat Creek

Marshall-Anvik district

ML 5611

Christensen, Robert \&

Kathleen (NG)

PO Box 871075

Wasilla, AK 99687-1075

Gold, Heavy metals

Unknown district

ML 5722

Chukchi Contracting Inc./ Chukchi Miners (NR)
PO Box 778

Kotzebue, AK 99752

Gold

Old Glory Creek

Noatak district

ML 9420

\section{CIRI (SCR}

PO Box 93330

Anchorage, AK 99509

Chromium

Eklutna area

Anchorage-Hatcher Pass district

ML 99021

\section{CIRI (SCR)}

PO Box 93330

Anchorage, AK 99509

Unknown commodity

Tyonek area

Anchorage district

ML 99023

\section{CIRI (SCR)}

PO Box 93330

Anchorage, AK 99509

Chromium

Seldovia area

Homer district

ML 99024, 99025

Clara Bea Inc. (WR)

PO Box 2561

Seward, AK 99723

Gold-Silver

Candle Creek

Fairhaven district

ML. 7489

Clark-Wiltz Co. Inc. (SWR)

PO Box 327

McGrath. AK 99627

Gold-Silver

Ganes Creek

Innoko district

ML 5696

Cominco Alaska

Exploration (NG)

PO Box 3087

Spokane, WA 99220

Base metals

Tributary to Talarik

Unknown district

ML 6118

Cominco American Inc. (WR)

15124 E. Euclid Ave

Spokane, WA 99216

Base metals

Divide and Quartz creeks

Cape Nome district

ML 5499

Conway, James P. (SCR)

HC 2 Box 7660

Palmer, AK 99645-7660

Gold-Silver
Poorman Creek

Yentna-Cache Creek district

ML 5689

Cook, Fred A. (EIR)

PO Box 311

Delta Junction, AK 99737-03II

Gold-Silver

Portage Creek

Bonnifield district

ML 9248

Cook's Mining (EIR)

PO Box 70456

Fairbanks, AK 99707-0456

Gold-Silver

Fairbanks Creek

Fairbanks district

ML 5955, 6973

Cope, Roger C. (NG)

PO Box 75404

Fairbanks, AK 99707-5404

Gold-Silver

Lewis Creek

Unknown district

ML 9411

Cyprus Gold Exploration

Corp. (EIR)

PO Box 3299

Englewood, CO 80112

Gold

Not given

Unknown district

ML 99107

DaGagne, Joseph III (SCR)

PO Box 877226

Wasilla, AK 99687

Gold-Silver

Cache Creek

Yentna district

ML 5741

Daglow Exploration (NR)

PO Box 80930

Fairbanks, AK 99708

Gold-Silver

Big Creek

Chandalar district

ML 9364

Delaney, Arley

HC 31 Box 5066

Wasilla, AK 99654

Gold-Silver

Purches Creek

Unknown district

ML 5737

Delima, Don P. (EIR)

PO Box 56106

Manley Hot Springs, AK 99756

Gold-Silver

Boulder Creek

Hot Springs district

ML 7194 
DeVore, Wesley (EIR)

6653 rd Ave.

Redwood City, CA 94063

Gold-Silver

Mosquito Fork, Fortymile River

Fortymile district

ML 9448,99121

\section{DeWitt, Estill (SCR)}

2260 Belmont Dr.

Anchorage, AK 99517

Gold-Silver

Caribou and Alfred creeks

Nelchina district

ML 99075

Dooley, Christopher (NG)

15411 Husky St.

Eagle River, AK 99577

Not given

Not given

Not given

ML 9470

Double J Mining (EIR)

Judd Edgerton

PO Box 34

Chicken, AK 99732

Gold-Silver

Napoleon Creek

Fortymile district

ML 7485

Ellet Management Co., Inc.

(EIR)

3535 Lansing Rd.

Charlotte, MI 48813

Gold-Silver

Olive Creek

Tolovana district

ML 9433

\section{Ellingson, Harold \& Alice}

(EIR)

1890 Steese Hwy.

Fairbanks, AK 99712

Gold-Silver

First Chance Creek

Fairbanks district

ML 9495

Ellis, Ed (SCR)

PO Box 13443

Trapper Creek, AK 99683

Gold-Platinum

Lake Creek

Yentna district

ML 5607

Ellis, Ed (SCR)

PO Box 13443

Trapper Creek, AK 99683

Gold-Platinum

Kahiltna River

Yentna district

ML 5735

Emerson, Robert C. (EIR) 1811 Phillips Field Rd.
Fairbanks, AK 99701

Gold-Silver

St. Patrick, Happy, and

Eva creeks

Fairbanks district

ML 5913

Engstrom Dredging Co. (WR)

PO Box 536

Nome, AK 99762

Gold-Silver

Basin Creek

Cape Nome district

ML 7116

Faa, Thomas (EIR)

PO Box 10906

Fairbanks, AK 99710

Gold-Silver

Eva Creek

Bonnifield district

ML 6801

Fair, Dan W. (NG)

3457 Old Richardson Hwy.

North Pole, AK 99705

Unknown commodity

Unknown district

ML 9144

Fairbanks Gold Mining Inc. (EIR)

PO Box 73726

Fairbanks, AK 99707

Gold

Melba Creek

Fairbanks district

ML 9156

Faulkner, Harry Sr. (SWR)

PO Box 1307

Bethel, AK 99559-1307

Gold-Silver

Ophir Creek

Aniak-Tuluksak district

ML 6157

Ferren, Danny W. (SCR)

PO Box 2248

Homer, AK 99603

Gold-Silver

Six Mile and Cub creeks

Hope district

ML 2705

Fichtelman, Guy/Don Collier (EIR)

PO Box 70

Chicken, AK 99732-0070

Gold-Silver

Fortymile River

Fortymile district

ML 9177

Fisher, Paul S. (EIR)

PO Box 71041

Fairbanks, AK 99707-1041

Gold-Silver
Doric Creek

Hot Springs district

ML 9317

Flat Creek Mining Co. Inc.

(SWR)

PO Box 81464

Fairbanks, AK 99708

Gold-Silver

Flat Creek

Marshall district

ML 5824

Flat Creek Placers (SWR)

General Delivery

Flat, AK 99584

Gold-Silver

Flat Creek

Iditarod district

ML 5503

Flat Pick Mining (EIR)

PO Box 115

Central, AK 99730-0115

Gold-Silver

Switch Creek

Circle district

ML 6892

Fogarty, James \& Sharon

(EIR)

3498 Laurance Rd.

North Pole, AK 99705

Gold-Silver

Flume Creek

Fairbanks district

ML 9373

Franko, Chris (EIR)

Escondido, CA 92029

Gold-Silver

Sourdough Creek

Fairbanks district

ML 9442

G.A. Hanks \& Sons (EIR)

18909 Old River Rd.

W. Sacramento, CA 95691

Gold-Silver

Lost Chicken Creek

Fortymile district

ML 5828

Gelvin, Stanley M. (EIR)

PO Box 30149

Central, AK 99730

Gold-Silver

Greenhorn Creek

Circle district

ML 9437

Geo Quest (EIR)

Michael Busby

PO Box 71

Chicken, AK 99732

Gold-Silver

Chicken Creek

Fortymile district

ML 6794
Gibson, Wayne (WR)

1610 Southern

Fairbanks, AK 99709

Gold-Silver

Golden Creek

Gold Hill-Melozitna district

ML 9032

Girdwood Mining Co. SCR)

PO Box 1089

Anchorage, AK 99587-1089

Gold-Silver

Crow Creek

Anchorage district

ML 5590

Glacier Six Enterprises (EIR)

Vic Justis

Route 2 Box 735

Soldotna, AK 99669

Gold-Platinum

Broxson Creek

Delta River district

ML 7311

Glassburn, Don E. (EIR)

PO Box 107

Central, AK 99730

Gold-Silver

Gold Dust Creek

Circle district

ML 7010

Global Resources Inc.

(EIR)

43445 Business Park Dr.

Temecula, CA 92590

Gold-Silver

Cripple Creek

Fairbanks district

ML 9132

Gold Hill Mining Co.

(EIR)

30033 Redwood Hwy.

Cave Junction, OR 97523

Gold-Silver

Harrison Creek

Circle district

ML 7289

Gold Star Mining (EIR)

Ross Novak

PO Box 83200

Fairbanks, AK 99708-3200

Gold-Silver

Eureka Creek

Hot Springs district

ML 7060

Golden Glacier Inc. (WR)

PO Box 1008

Nome, AK 99762

Gold-Silver

Cooper Gulch

Cape Nome district

ML 99127 
Goodson, Richard (EIR)

2605 E. 50 th. \#8

Anchorage, AK 99507

Gold-Silver

North Fork Fortymile River

Fortymile district

ML 9052

Granath, Gene A. (SCR)

PO Box 574

Kenai, AK 99611-0574

Gold-Silver

Falls Creek

Hope-Sunrise district

ML 5633

Granite Creek Mining (SWR)

PO Box 261

McGrath, AK 99627-026

Gold-Silver

Granite Creek

McKinley-Iditarod district

ML 6223

Green Mining \&

Exploration (EIR)

PO Box 61455

Fairbanks, AK 99706-1455

Gold-Silver

Hunter Creek

Rampart district

ML 9396

Green Mining \&

Exploration (EIR)

PO Box 61455

Fairbanks, AK 99706-1455

Gold-Silver

Birch Creek

Circle district

ML 9136

Green Mining \&

Exploration (WR)

PO Box 61455

Fairbanks, AK 99706-1455

Gold-Silver

Long Creek

Ruby district

ML 709

Greene, Steve (EIR)

1648 Tamarack

Fairbanks, AK 99709

Gold-Silver

Davis Creek

Fortymile district

ML 9089

Grizzly Bar Development LLC (SER)

PO Box 20270

Juneau, AK 99802-0270

Gold-Silver

Taku River

Juneau district

ML 5739
Groppel, Chris L. (EIR)

PO Box 1060

Delta Junction, AK 99737-1060

Gold-Silver

Tenderfoot Creek

Richardson district

ML 5944

Gumaer, Mark \& Robin (WR)

PO Box 1682

Nome, AK 99762-1682

Gold-Silver

Dick Creek

Kougarok district

ML 7223

Hall, John B. (NR)

PO Box 72700

Fairbanks, AK 99707-2700

Gold-Silver

Linda Creek

Koyukuk district

ML 7203

\section{Hannah, John (EIR)}

PO Box 61117

Fairbanks, AK 99706-1117

Gold-Silver

Flume, Moose, and Pedro creeks

Fairbanks district

ML 9035

Hansen, Kenneth C. (EIR)

PO Box 10657

Fairbanks, AK 99710

Gold-Silver

Faith Creek

Fairbanks district

ML 7047

Hassel, Gerald (EIR)

PO Box 49

Ester, AK 99725-0049

Gold-Silver

Ready Bullion Creek

Fairbanks district

ML 7201

Hayden, Forest A. (EIR)

PO Box 110930

Anchorage, AK 99511

Gold-Silver

Baby and Squaw creeks

Fortymile district

ML 99093

Heflinger Mining Co. (EIR)

665 10th Ave., \#307

Fairbanks, AK 99701

Gold-Silver

Livengood Creek

Livengood-Tolovana district

ML 7235

Heflinger, Fred (EIR)

PO Box 82390
Fairbanks, AK 99708

Gold-Silver

Walker Fork

Fortymile district

ML 9124

Herman, Daniel C. (NG)

Red Devil, AK 99656

Gold-Silver

Millie Creek

Unknown district

ML 99099

Herndon \& Thompson Leasing Co. (SCR)

41745 Bear Creek Rd.

Homer, AK 99603

Gravel

Homer district

ML 99018,99019

Herning, Bruce G. (EIR)

PO Box 73846

Fairbanks, AK 99707-3846

Gold-Silver

Palmer Creek

Fairbanks district

ML 4482

Herzog, Martin M. (SCR)

438 Sundew Lane

Fairbanks, AK 99712

Gold-Silver

Cache Creek

Yentna district

ML 6073

High Bench Mining (WR)

Daniel Walsh

4600 Mars Dr.

Anchorage. AK 99507

Gold-Silver

Dexter and Anvil creeks

Cape Nome district

ML 5994

Hooper, Gerald W.

PO Box 71

Soldtona, AK 99669

Gold-Silver

Swift Creek

Unknown district

ML 9048

Hopen, Alf M. (EIR)

PO Box 74246

Fairbanks. AK 99707

Gold-Silver

Cleary Creek

Fairbanks district

ML 99039

House, Conrad H. (NG)

3911 Tilleson Way

North Pole, AK 99705

Gold-Silver

Swift Creek
Unknown district

ML 5823

Hron, Thomas (SCR)

4125 Aircraft Dr.

Anchorage, AK 99502

Gold-Silver

Lake Creek

Yentna district

ML 5740

Jackson Mining Co.

(EIR)

936 Coppet St.

Fairbanks, AK 99709

Gold-Silver

Totatlanika River

Bonnifield district

ML 7469

Jacobs, David (EIR)

HCl Box 3090

Healy, AK 99743

Gold-Silver

Rex Creek

Bonnifield district

ML 9329

Jensen, Daniel D. (EIR)

PO Box 12

Delta Junction, AK 99737-0012

Gold-Silver

McComber Creek

Delta River district

ML 7593

Jiles, Overton J. (NG)

5250 Auburn Folsom Rd.

Loomis, CA 95650

Gold

Gold Bottom Gulch

Unknown district

ML 7249

Johnson, Ernest (NG)

222 Kern St.

Taft, CA 93268

Not given

Not given

Unknown district

ML 9478

Johnson, Gregory (SCR)

12141 Curtic Circle

Eagle River, AK 99577

Gold-Silver

Bird Creek

Anchorage district

ML 5742

Keller, Robert W. (EIR)

PO Box 385

Huntington, OR 97909-0385

Gold-Silver

Totatlanika River

Bonnifield district

ML 5889 
Kelly, Tim (EIR)

PO Box 112

Manley, AK 99756

Gold-Silver

North Fork Creek

Hot Springs district

ML 7057

Kiehl, Don T. (EIR)

3210 Marneet Lane

North Pole, AK 99705

Gold-Silver

Gold King Creek

Bonnifield district

ML 5871

Kile, Alvin \& Eric (EIR)

PO Box 140424

Anchorage, AK 99514-0424

Gold-Silver

Canyon and Camp creeks

Fortymile district

ML 5838

Klopman, Jamin/Joe

Daugherty

HC04 9749

Palmer, AK 99645

Gold-Silver

Taylor West

Fortymile district

ML 5681

Knutson, Theodore (EIR)

PO Box 1298

Chouteau, OK 74337-1298

Gold-Silver

Mammoth Creek

Circle district

ML 7323

\section{Kralik, Jan (WR?)}

PO Box 1793

Nome, AK 99762-1793

Gold-Silver

Gold Run

Unknown district

ML 5864

Krug, Randy (EIR)

28514 134th St. E

Buckley, WA 98321

Gold-Silver

Sourdough

Fairbanks district

ML 9447

\section{Krzykowski, Ben (EIR)}

PO Box 60091

Fairbanks, AK 99706-0091

Gold-Silver

Big Eldorado Creek

Fairbanks district

ML 5981

Kukowski, Dave (EIR)

P.O Box 6
Chicken, AK 99732

Gold-Silver

Mosquito River

Fortymile district

ML 7220

LaCross, Jack (SCR)

PO Box 387

Trapper Creek, AK 99683

Gold-Silver

Fergy Creek

Yentna-Cache Creek district

ML 2704

Lankford, Steve E. (SCR)

HC 89 Box 540

Willow, AK 99688-0549

Gold-Silver

Albert Creek

Nelchina district

ML 7362

Las, Alan E. (EIR)

PO Box 55069

North Pole, AK 99705-5069

Gold-Silver

No Grub Creek

Fairbanks district

ML 7362

Lines, Lester E. (EIR)

PO Box 103820

Anchorage, AK 99510-3820

Gold-Silver

North Fork Harrison Creek

Circle district

ML 7332

Little Eldorado Group (EIR)

W.L. Shaffer

PO Box 80148

Fairbanks, AK 99708

Gold-Silver

Near Little Eldorado Creek

Fairbanks district

ML 9094

Losonsky, Steve (EIR)

PO Box 80321

Fairbanks, AK 99708-0321

Gold-Silver

Hunter Creek

Rampart district

ML 7328

Loud, Richard L. (EIR?)

PO Box 10570

Fairbanks, AK 99710-0570

Gold-Silver

Harrison Creek

Circle district

ML 6006

Lounsbury Mining Inc. NR)

PO Box 70983

Fairbanks, AK 99707-0983

Gold-Antimony
Union Gulch

Koyukuk-Nolan district

ML 9165

Lucky Seven Mining (EIR)

Ron Roman

PO Box 71614

Fairbanks, AK 99707

Gold-Silver

Last Chance Creek

Fairbanks district

ML 9105

Lyle Avenue LLC (NG)

PO Box 56186

North Pole, AK 99705

Not given

Not given

Unknown district

ML 99117

Mason, Arnold J. (EIR)

PO Box 140467

Anchorage, AK 99514

Gold

North Creek

Cache district

ML 5516

Matter, Mark (SWR)

PO Box 44

Aniak, AK 99557-0044

Gold-Silver

Marvel Creek

Aniak-Tuluksak district

ML 5617

Maxwell, Leslie or Barbara

(EIR)

3910 Loc Sault Ave.

Anchorage, AK 99516

Gold-Silver

Canyon Creek

Fortymile district

ML 6344

May, Don (EIR)

4545 Woodriver Drive

Fairbanks, AK 99709

Gold-Silver

Ridge Top

Fairbanks district

ML 9427

Maydole, Peter (EIR)

PO Box 302

Healy, AK 99743

Gold-Silver

California Creek

Bonnifield district

ML 9450

MC Mining (NG)

PO Box 870750

Wasilla, AK 99687

Gold-Silver

White Creek
Unknown district

ML 99113

McPherson, Roger

(EIR)

1042 Gilmore St.

Fairbanks, AK 99701

Gold-Antimony

Hattie Creek

Fairbanks district

ML 7015

McWilliams, Howard (SCR)

PO Box 221603

Anchorage, AK 99522

Gold-Silver

Chuilna

Yentna district

ML 99053

Metco Inc. (SCR)

HCR 64 Box 300

Seward, AK 99664

Gravel

Homer district

ML 99016

Miller, Lawrence (NG)

PO Box 182

Healy, AK 99743

Unknown commodity

Unknown district

ML 9372

Minex International Inc. (NG)

PO Box 103

Girdwood, AK 99587-0103

Unknown commodity

Unknown district

ML 5006

Miscovich, Andrew W.

(EIR)

PO Box 71489

Fairbanks, AK 99707-1489

Gold-Silver

Chatham Creek

Fairbanks district

ML 3014

Mitchell, Harold

(EIR)

PO Box 65

Chicken, AK 99732-0065

Gold-Silver

Mosquito Fork

Fortymile district

ML 7282

Montogomery, Melvin or Lois (EIR)

6028 Mackay

Anchorage, AK 99518

Gold-Silver

Gilliland Creek

Fortymile district

ML 9168 
Monzulla, Vincent C.

\section{(EIR)}

2920 Monzulla Ln.

Fairbanks, AK 99712

Gold-Tungsten

Victoria Creek

Fairbanks district

ML 625

Moore, Roger (EIR)

288 Rambling Rd.

Fairbanks, AK 99712

Gold-Silver

Ester Creek

Fairbanks district

ML 9331

Morgan, Tom (EIR)

842 Poirier St.

Coq, BC V3J $6 \mathrm{C} 2$

Canada

Gold

McCord Creek

Fairbanks district

ML 5893

Morris, Claude (NG)

PO Box 547

Girdwood, AK 99587

Not given

Not given

Unknown district

ML 6089

Morris Mining (NG)

General Delivery

Willow, AK 99688

Gold-Silver

Grubstake Gulch

Unknown district

ML 99120

Mrak, William (SCR)

PO Box 1963

Palmer, AK 99645-1963

Gold

Willow and Grubstake creeks

Hatcher Pass district

ML 6220

Mullikin, Christopher L. (WR)

PO Box 790

Homer. AK 99603-0790

Gold-Silver

Boulder and Turner creeks

Kougarok district

ML 9061

Mullikin, Dan (WR)

PO Box 790

Homer, AK 99603-0790

Gold-Silver

Noxapaga and Boulder creeks

Kougarok district

ML 7271

Munsell, James L. (EIR)

PO Box 81155
Fairbanks, AK 99708-1155

Gold-Silver

Little Minook Jr.

Rampart district

ML 5862

NB Tweet \& Sons (WR)

PO Box 1107

Nome, AK 99762-1107

Gold-Silver

Kougarok River

Kougarok district

ML 5845

Ness, Ken (NG)

1137 Tower Rd.

Castle Rock, WA 9861।

Not given

Not given

Unknown district

ML 99109

Nevers, Harold A. (EIR)

8148 Pinewood Dr.

Juneau, AK 99801

Gold-Silver

American Creek

Hot Springs district

ML 7284

Newmont Exploration Ltd.

(EIR)

1818 Steese Hwy.

Fairbanks, AK 99712

Gold-Silver

Dome and Little Eldorado creeks

Fairbanks district

ML 7522

Nicholson, Doug \& Peter

Frantz (NR)

3865 Ullrbahn

Fairbanks, AK 99709

Gold-Silver

Linda Creek

Koyukuk district

ML 9080

Nordeen, William $\mathbf{H}$.

(NR)

PO Box 9013

Fairbanks, AK 99701-9013

Gold-Silver

Emma Creek

Koyukuk-Nolan district

ML 7372

Nova Natural Resources Corp. (WR)

PO Box 481388

Denver, CO 80248-1388

Gold-Silver

Cape Nome district

ML 9092

Nyac Mining Co. (SWR)

Tuluksak Dredging Ltd.

4158 th Ave.
Anchorage, AK 99501

Gold-Silver

Bear Creek

Aniak-Tuluksak district

ML 5641

O'Donnell, Franklin L. Jr.

(EIR)

7110 Canaday Rd.

Salcha, AK 99714

Gold-Silver

Moose Creek

Bonnifield district

ML 8978

Old Yeller Mine (SCR)

Ralph Simonson

72382 Palmer Jct. Rd.

Elgin, OR 97827

Gold-Silver

Surprise Creek

Valdez Creek district

ML 6736

Olson, Alan G. (WR)

PO Box 165

Palmer, AK 99645-0165

Gold-Silver

Candle Creek

Candle district

ML 6219

Olson, Dave (WR)

PO Box 1835

Nome, AK 99762

Gold-Silver

Canyon Creek

Cape Nome district

9434

Olson, Gordon E. (EIR)

7100 N. Milford Rd.

Holly, MI 48442

Gold-Silver

Jack Wade Creek

Fortymile district

ML 5923

Olson, Stephen G. (EIR)

PO Box 106

Tok. AK 99780-0106

Gold-Silver

Liberty Creek

Fortymile district

ML 5883

\section{Olson, Steven L.}

(EIR)

PO Box 10655

Fairbanks, AK 99710-0655

Gold-Silver

Eagle Creek

Fortymile district

ML 6925

Omega Mining Co.

(EIR)

Richard Ott
PO Box 72748

Fairbanks, AK 99707

Gold-Silver

Omega Creek

Fortymile district

ML 9062

Owen, Jeff (EIR)

Box BYA

Tok, AK 99780

Gold-Silver

Younger Creek

Fortymile district

ML 5807

Owen, Ted (EIR)

12307 E. Stillwater

Redding, CA 96003

Gold-Silver

Walker Fork

Fortymile district

ML 9039

Pacific Alaska Resources (EIR)

PO Box 4879

Vancouver, WA 98662

Gold-Base metals

Stonehouse Creek area

Bonnifield district

ML 9463

Pacific Mining (NG)

PO Box 110842

Anchorage, AK 99511

Gold-Silver

Porcupine Creek

Unknown district

ML 9129

Paradise Valley Inc. (NR)

Bettles, AK 99726

Gold-Silver

Birch, Oregon, and Angess

creeks

Koyukuk-Nolan district

ML 6921

Parr, Glen C. (EIR)

624 Maple

Shelton, WA 98584

Gold-Silver

Little Moose Creek

Bonnifield district

ML 6936

Paul \& Co. (EIR)

PO Box 83102

Fairbanks, AK 99708

Gold-Silver

Frying Pan Creek

Circle district

ML 9407

Penz, Dave (SWR)

PO Box 29

Russian Mission, AK 99657

Gold

Buster Creek 
Marshall district

ML 6216

Perkins Mining Tech (SCR)

PO Box 671475

Chugiak, AK 99567

Gold-Silver

Willow Creek

Willow Creek district

ML 5746, 5749

Peterson, Donald E. (SER)

PO Box 172

Haines, AK 99827

Gold-Silver

Porcupine Creek

Juneau district

ML 5700

Pharis, Michael \& Jim

Olmstead (NR)

3410 Tilleson Way

North Pole, AK 99705

Gold-Silver

Gold Creek

Koyukuk-Nolan district

ML 9403

Philpott, Roy (EIR)

PO Box 72198

Fairbanks, AK 99707-2198

Gold-Silver

Smith Creek

Koyukuk-Nolan district

ML 5830

Placer Dome US Inc. (NG) 200 W Int'l Airport Rd. C-1

Anchorage, AK 99502

Not given

Not given

Unknown district

ML 9456

Placer Dome US Inc. (NG)

240 S. Rock \#117

Reno, NV 89502

Not given

Not given

Unknown district

ML 9432, 9439

Plano, Dan and Cindy (SWR) PO Box 878275

Wasilla, AK 99687-8275

Gold-Silver

Anvil Creek/Innoko River Innoko district

ML 5570

Point Lena Investments LLC (SER)

PO Box 32159

Juneau, AK 99803

Not given

Formerly Red Samm Creek

Juneau district

ML 99111
Pomrenke, Steve (WR)

PO Box 308

Nome, AK 99762

Gold-Silver

Tripple Creek

Cape Nome district

ML 9055

Pushcar, Jerry (WR)

PO Box 1604

Nome, AK 99762

Gold-Silver

Iron and Benson creeks

Unknown district

ML 9462

Quartz Creek Exploration

(SCR)

Milo Floth

PO Box 242

Sterling, AK 99672

Gold-Silver

Quartz Creek

Hope district

ML 6208

Read, Donald M. (EIR)

PO Box 71638

Fairbanks, AK 99707-1638

Gold-Silver

Vault Creek Bench

Fairbanks district

ML 7293

Redmond, Richard J. (NG)

PO Box 8700

Indian, AK 99540-8700

Unknown commodity

Unknown district

ML 6366

Reed, Scott C. (EIR)

PO Box 453

Crown King, AZ 86343

Gold-Silver

North Fork Fortymile River

Fortymile district

ML 9387

Regner, Leo A. (EIR)

PO Box 72733

Fairbanks, AK 99707-2733

Gold-Silver

Lilliwig and Ingle creeks

Fortymile district

ML 6037

Renk, Russell (WR)

641 W. 91 st Ave

Anchorage, AK 99515

Gold-Silver

Willow Creek

Solomon district

ML 5718

Roberts, Robert W. (EIR)

PO Box 225

Tok, AK 99780
Gold-Silver

Chicken Creek

Fortymile district

ML 7303

Roberts, Roger L. (SWR)

PO Box 7

Ophir-Takotna, AK 99675-0007

Gold-Silver

Ophir and Gold Run creeks

Innoko district

ML 8078

Roop, John Sr. (EIR)

9499 Brayton Dr., \#22

Anchorage, AK 99507

Gold-Silver

Fortymile River

Fortymile district

ML 5974

Rosander Mining Co.

(WR)

PO Box 129

McGrath, AK 99627-0129

Gold-Silver

Colorado Creek

Innoko district

ML 6806

Rowallan Inc. (SCR)

PO Box 318

Clam Gulch, AK 99568-0318

Gold-Silver

White and Valdez creeks

Valdez Creek district

ML 5552

\section{RSH Company (SER)}

Ralph Horecny

PO Box 211474

Auke Bay, AK 99821-1474

Sand and Gravel

Lemon Creek

Juneau district

ML 99014

RSH Company (SER)

Ralph Horecny

PO Box 211474

Auke Bay, AK 99821-1474

Sand and Gravel

Lemon Creek

Juneau district

ML 99015

Rubel, John D. (EIR)

8183 Richardson Hwy.

Salcha, AK 99714

Gold-Silver

Banner Creek

Richardson district

ML 7334

Ryan Lode Mines (SCR)

2173 University Ave. S., \#101

Fairbanks, AK 99709

Gold
Lucky Gulch

Valdez Creek district

ML 2701, 9096

Sather, Norman M. (EIR)

1213 Coppet St.

Fairbanks, AK 99709

Gold-Silver

Fairbanks Creek

Fairbanks district

ML 7112

\section{Sayer, Paul (SWR)}

PO Box 10

Homer, AK 99603-0010

Gold-Silver

Little Creek

Innoko district

ML 6233

Schafer, Beatrice/Terry Russell

(NG)

PO Box 55074

North Pole, AK 99705-5074

Unknown commodity

Unknown district

ML 9390

Schene, Earl L. (EIR)

PO Box 66

Chicken, AK 99732-0066

Gold-Silver

Uhler Creek

Fortymile district

ML 6937

Schnabel, John J.

(SER)

PO Box 149

Haines, AK 99827

Gold-Silver

Porcupine Creek

Porcupine district

ML 7401

Schwartz, John (EIR)

PO Box 19

Chicken, AK 99732

Gold-Silver

Our Creek

Fortymile district

ML 9322

Scofield, Walter P. (EIR)

PO Box 945

Tok, AK 99780-0945

Gold-Silver

South Fork Fortymile River

Fortymile district

ML 7451

SDC Mining (NG)

1095 Violet Dr.

Fairbanks, AK 99712

Not given

Not given

Unknown district

ML 9446 
Sebons, Mark (SER)

PO Box 1107

Haines, AK 99827

Gold-Silver

Porcupine Creek

Juneau district

ML 2700

Secon Inc. (SER)

10505 NE 38th Pl.

Kirkland, WA 98033

Sand and Gravel

Lena Point

Juneau district

ML 99070

Seuffert, George Jr. (EIR)

7705 Port Orford Dr.

Anchorage, AK 99516

Gold-Silver

Jack Wade Creek

Fortymile district ML 9401

Shilling, John A. (EIR)

PO Box 81424

Fairbanks, AK 99708-1424

Gold-Tin

Thanksgiving Creek

Hot Springs district

ML 7503

Silverado Mines (U.S.) Inc.

(NR)

PO Box 83730

Fairbanks. AK 99708-3730

Gold-Antinomy

Nolan Creek

Koyukuk-Nolan district

ML 7084

Skookum Mining (EIR)

PO Box 10139

Fairbanks, AK 99710-0139

Gold-Silver

Portage Creek

Bonnifield district

ML 8875

Smith, William L. (SCR)

906 Cunningham St.

Anchorage, AK 99501

Gold-Silver

Silvertip Creek

Seward district

ML 6054

Snyder, Donald L. (EIR)

PO Box 54

Chicken, AK 99732

Gold-Silver

South Fork Fortymile River

Fortymile district

ML 1482

Soule, Harold L. (SCR)

2840 E. 142nd Ave.
Anchorage, AK 99516

Gold-Silver

Windy Creek

Valdez Creek district

ML 5560

Sound Quarry Inc. (WR)

PO Box 1008

Nome, AK 99762

Rock

Cape Nome

Cape Nome district

ML 991020, 99126

Stebbins Native Corp. (WR)

PO Box 70110

Stebbins, AK 9967I

Gravel, sand, and stone

Unidentified

Candle district

ML 99011

Stec, Russell E./Larry Fine

(WR)

PO Box 940316

Houston, AK 99694-0316

Gold-Silver

East Fork Iron Creek

Solomon district

ML 6491

Stein, Robert D. (EIR)

105 Dunbar Ave.

Fairbanks, AK 99701

Gold-Silver

Gilmore Creek

Fairbanks district

ML 5909

Sternberg, Tom (NG)

3154 E. 19th Ct.

Anchorage, AK 99508

Unknown commodity

Unknown district

ML 5725

Stough, Richard B. (EIR)

PO Box 711

Wrangell, AK 99929-0711

Gold-Silver

Dome Creek

Fairbanks district

ML 4277

Stultz, Donald D. (EIR)

PO Box 700

Nome, AK 99762

Gold-Silver

Oregon Creek

Cape Nome district

ML 5983

Surf Food Products, Inc. (AP)

771697 th Ave. SW

Tacoma, WA 98498

Gravel-Rock

Kodiak district

ML 5731, 9404
Surprise Mining Co. (SCR)

Aubrey, Larson, Staggs

PO Box 11700

Chickaloon, AK 99674-1170

Gold-Silver

Glass Creek

Hatcher Pass district

ML 5727

Swarthout, Ralph

PO Box 141801

Anchorage, AK 99514-1801

Not given

Not given

Unknown district

ML 5649

Swenson, Lloyd D. (EIR)

1843 Bridgewater Dr.

Fairbanks, AK 99709

Gold-Silver

Slate Creek

Rampart district

ML 7343

Swenson, Richard A.

(EIR)

PO Box I6205

Two Rivers, AK 99716-6205

Gold-Silver

Doric Creek

Hot Springs district

ML 6872

Swenson, Richard (EIR)

PO Box 16205

Two Rivers, AK 99716-6205

Gold-Silver

Eureka Creek

Hot Springs district

ML 9473

Tachik, Wayne H. (EIR)

PO Box 3503

Soldotna, AK 99669-3503

Gold-Silver

Moose Creek

Bonnifield district

ML 6719

Taiga Mining Co. Inc.

(WR)

4740 E. 115 th Ave,

Anchorage, AK 99516

Gold-Silver

Clear Creek

Koyukuk-Hughes district

ML 9017

Taiga Mining Co. Inc.

(WR)

4740 E. 115 th Ave.

Anchorage, AK 99516

Gold-Silver

Bear and Ida creeks

Koyukuk-Hughes district

ML 9139
Taiga Mining Co. Inc.

(WR)

4740 E. 115th Ave.

Anchorage, AK 99516

Gold-Silver

Dry Creek

Koyukuk-Hughes district

ML 9388

Tallini, Roger P. (EIR)

PO Box 3474

Flagstaff, AZ 86003-3474

Gold-Silver

South Fork Fortymile River

Fortymile district

ML 9028

Tatlow Carl D. \& Janice L. (SCR)

PO Box 1621

Palmer, AK 99645

Gold-Silver

Peters Creek

Yentna district

ML 5736

Taylor, Larry R. (EIR)

PO Box 101

Eagle, AK 99738-0101

Gold-Silver

Fortymile River

Fortymile district

ML 9179

Teslin Mining Co. (NG)

PO Box 1989

Nome, AK 99762

Not given

Not given

Unknown district

ML 9436

The Gravel Station (SCR)

Turner

PO Box 3489

Palmer, AK 99645-3489

Sand and Gravel

Hornung Property

Hatcher Pass district

ML 99013

Thompson, Kevin (SCR)

PO Box 875534

Wasilla, AK 99687-5534

Gold-Silver

Gold Hill above White Creek

Valdez Creek district

ML 5729

Thurman Oil \& Mining Inc. (EIR)

925 Aurora Dr.

Fairbanks, AK 99709

Gold-Silver

Rhode Island Creek

Hot Springs district

ML 9125 
Thurman Oil \& Mining Inc. (WR)

925 Aurora Dr

Fairbanks, AK 99709

Gold-Silver

Quartz 7 and Dahl creeks

Candle district

ML 9398

Tileson Mining (EIR)

PO Box 55823

North Pole, AK 99705-5823

Gold-Silver

California Creek

Bonnifield district

ML 9192

Toohey, Cynthia (SCR)

PO Box 113

Girdwood, AK 99587-0113

Gold-Silver

Crow Creek

Anchorage district

ML 5564

Treesh, James W. (SCR)

18550 Man O'War Rd.

Eagle River, AK 99577

Gold-Silver

No Name Creek

Hope-Sunrise district

ML 9384

Treider, Eric (NG)

PO Box 8138

Nikiski, AK 99635

Not given

Not given

Unknown district

ML 5748

Trinity Mining (WR)

Cheryl Jong

PO Box 372

Kotzebue, AK 99752

Gold-Silver

Washington Creek

Kougarok district

ML 5844

TruDeck Mining (EIR)

PO Box 135

Healy, AK 99743-0135

Polymetallic

Sheep Creek

Bonnifield district

ML 9369

Ventures Resources Alaska

Corp. (NG)

PO Box 100059

Anchorage, AK 99510-0059

Base-Precious metals

Various

Unknown district

ML 5743
Vogt, Ray A. (NG)

4200 Elliott Hwy.

Fairbanks, AK 99712

Not given

Not given

Unknown district

ML 7021

Voytilla, Earl W.

(EIR)

PO Box 58901

Fairbanks, AK 99710

Gold-Silver

Tenderfoot

Richardson district

ML 5868

Walton, Ross (EIR)

1247 Hartzog Lp.

North Pole, AK 99705

Gold-Silver

Dome Creek

Fairbanks district

ML 5847

Watts, Donald
(EIR)

PO Box 81515

Fairbanks, AK 99708

Gold-Silver

Grubstake Creek

Bonnifield district

ML 5865

Weathers, Douglas \& Edith
(SCR)
PO Box 8082
Nikiski, AK $99635-8082$
Gold-Silver
Cache Creek
Yentna district
ML 6209

Wegley, Mike \& Jean (NG)

71297 N. Shore Dr

Birkenfield, OR 97016

Not given

Not given

Unknown district

ML 9453

Western Mining Corp. (NG)

4750 Longley Lane, Suite 106

Reno, NV 89502

Not given

Various

Unknown district

ML 5750

Wicken, James T. (NR)

1709 Central Ave.

Fairbanks, AK 99709

Gold

Gold Creek

Koyukuk-Nolan district

ML 5947
Wiggers, Dan A. (NR)

HC 30 Box 5283

Wasilla, AK 99654

Gold-Silver

Hammond River

Koyukuk-Nolan district

ML 6859

Wilde, Jim \& Lore

(EIR)

PO Box 30068

Central, AK 99730

Gold-Silver

Switch Creek

Circle district

ML 5998

Wilder, Richard (EIR)

117 Elray St.

Fairbanks, AK 99709

Gold-Silver

Little Boulder

Hot Springs district

ML 5939

Wilkinson, Fred D.

(EIR)

PO Box 1

Central, AK 99730

Gold-Silver

Ketchem Creek

Circle district

ML 5997

Willard, Gerald L. (NG)

PO Box 875532

Wasilla, AK 99687

Unknown commodity

Unknown district

ML 5724

Willford, Frank (EIR)

1079 Victor St,

North Pole, AK 99705

Gold-Silver

Tributary to Hoosier Creek

Rampart district

ML 7358

Willis, Dean L. (EIR)

PO Box 30063

Central, AK 99730-0063

Gold-Silver

Crooked Creek

Circle district

ML 5929

Wilmarth, Richard C. (SWR)

PO Box 33

Red Devil, AK 99656

Gold-Silver

Chicken Creek

Iditarod district

ML 6351

Winslow, Jeffery A. (NG)

PO Box 521564
Big Lake, AK 99652

Gold-Silver

Falls Creek

Unknown district

ML 99108

Wishbone Sand \& Gravel (SCR)

Robert A. Navrot

PO Box 252

Sutton, AK 99674

Sand and Gravel

Anchorage district

ML 99130

Wolf, Ray (EIR)

30033 Redwood Highway

Cave Junction, OR 97523

Gold-Silver

North Fork Harrison River

Circle district

ML 9363

Wolff, Flint, L. (EIR)

Box BYA

Tok, AK 99780

Gold-Silver

Walker Fork

Fortymile district

ML 99048

Wolff, Gordon C. (SCR)

$618 \mathrm{~W} .86$ th $\mathrm{Ct}$.

Anchorage, AK 99515

Gold-Silver

Peters Creek

Yentna-Cache Creek district

ML 8083

Wood, James (WR)

PO Box 58597

Fairbanks, AK 99711-8597

Gold-Silver

Little Boulder Creek

Cape Nome district

ML 6953

Wrede, Ron (EIR)

2116 NE 80

Seattle, WA 98115

Gold-Silver

Switch Creek

Circle district

ML 9049

Wright, Richard L. (NR)

3410 Tilleson Way

North Pole. AK 99705

Gold-Silver

Gold Creek

Koyukuk-Nolan district

ML 9085

Wright, Robert P. (EIR)

PO Box 60783

Fairbanks, AK 99706-0783

Gold-Silver 
Last Chance Creek

Fairbanks district

ML 9155

Wyka, Wayne (EIR)

PO Box 7405!

Fairbanks, AK 99707

Gold-Silver

Fortymile Creek

Fortymile district

ML 9477
Yellow Eagle Mining Inc. (EIR)

PO Box 80566

Fairbanks, AK 99708

Gold-Silver

Ester and Cripple creeks

Fairbanks district

ML 9127

Yutan Construction Co. (EIR)

PO Box 71775

Fairbanks, AK 99707
Rock

Browns Hill

Fairbanks district

ML 99026

Zimmer, George W. (WR)

PO Box 140174

Anchorage, AK 99514-0174

Gold-Silver

Quartz Creek

Koyukuk district

ML 5555
Zimmerman, Charles J. (EIR)

PO Box 41

Manley Hot Springs, AK 99756

Gold-Silver

Killarney Creek

Hot Springs district

ML 9392 


\section{APPENDIX D}

\section{Selected significant mineral deposits and mineral districts in Alaska ${ }^{\mathrm{a}}$}

The alphabetized list of mineral deposits and mineral districts is keyed to the list of explanatory paragraphs that follow. For example, The Lik deposit in the alphabetized list is "Lik, 1, (fig. D-1)." This says that the location of Lik is shown as number 1 in figure D-1.

Alaska-Juneau, 100, (fig. D-3).

Anderson Mountain, 54, (fig. D-1).

Apex-El Nido, 104, (fig. D-3).

Apollo-Sitka mines, 86, (fig. D-3).

Aretic, 9, (fig. D-1).

Avan Hills, 12, (Fig. D-3).

Baultoff, 75, (fig. D-2).

Bear Mountain, 21, (fig. D-2).

Big Creek/Ladue, 58, (fig. D-1).

Big Hurrah, 32, (fig. D-3).

Binocular and other prospects, 72 , (fig. D-1).

Bohemia Basin, 103, (fig. D-3).

Bokan Mountain, 122, (fig. D-3).

Bonanza Creek, 45, (fig. D-2).

Bond Creek, 73, (fig. D-2).

Bonnifield district massive sulfide deposits, 54, (fig. D-1).

Bornite, 8, (fig. D-1).

Brady Glacier, 98, (fig. D-3).

BT, 54, (fig. D-1).

Buck Creek, 23, (fig. D-2).

Cape Creek, 22, (fig. D-2).

Carl Creek, 74, (fig. D-2).

Casca VABM, 53, (fig. D-1).

Castle Island, 111, (fig. D-1).

Chandalar mining district, 17, (fig. D-3),

Chichagof, 101, (fig. D-3).

Chistochina, 68, (fig. D-3).

Circle mining district, 52, (fig. D-3).

Claim Point, 82, (fig. D-3).

Coal Creek, 63, (fig. D-2).

Copper City, 119, (fig. D-1).

Cornwallis Peninsula, 110, (fig. D-1).

Council mining district, 33, (fig. D-3).

Delta massive sulfide belt, 55 , (fig. D-1).

Denali prospect, 67, (fig. D-1).

Dolphin, 49e, (fig. D-3).

Donlin Creek-Aniak district, 84, (fig. D-3).

Drenchwater, 3, (fig. D-1).

Dry Creek, 54, (fig. D-1).

Ear Mountain, 25, (fig. D-2).

Ellamar, 78, (fig. D-1).

Ernie Lake (Ann Creek), 15, (fig. D-1).

Esotuk Glacier, 20, (fig. D-2).

Fairbanks mining district, 49, (fig. D-3).

Fairhaven/Inmachuk district, 39, (fig. D3).

Fort Knox, 49a, (fig. D-3).

Fortymile mining district, 60, (fig. D-3).

Frost, 7a, (fig. D-1).

Funter Bay mining district, 99, (fig. D-3).

Galena Creek, 21a, (fig. D-1).

Ginny Creek, 4, (fig. D-1).

Golden Zone mine, 64, (figs. D-1, D-3).

Goodnews Bay, 85, (fig, D-3).
Grant Mine, 49c, (fig. D-3).

Greens Creek, 105, (fig. D-1).

Groundhog Basin, 112, (fig. D-1).

Haines Barite, 95, (fig. D-1).

Hannum, 27, (fig. D-1).

Hirst Chichagof, 101, (fig. D-3).

Horsfeld, 76, (fig. D-2).

Hot Springs mining district, 47. (fig. D-3).

Hyder mining district, 117, (figs. D-1, D-2).

Iditarod district, 43a, (fig. D-3).

Illinois Creek, 44a, (fig. D-1).

Independence, 79, (fig. D-3).

Independence Creek, 28, (fig. D-1).

Inmachuk River, 39, (fig. D-3).

Innoko-Tolstoi mining district, $43 \mathrm{~b}$, (fig. D-3).

Ivanof, 88, (fig. D-2).

Jimmy Lake, 94, (fig. D-1).

Johnson River, 125, (fig. D-3).

Jualin, 128, (fig. D-3).

Jumbo, 118, (fig. D-1).

Kachauik, 34, (fig. D-3).

Kantishna mining district, 61, (fig. D-3).

Kasaan Peninsula, 114, (fig. D-1).

Kasna Creek, 92, (fig. D-1).

Kemuk Mountain, 123, (fig. D-3).

Kennecott deposits, 71, (fig. D-1).

Kensington, 127, (fig. D-3).

Kivliktort Mountain, 5a, (fig. D-1).

Klery Creek, 14, (fig. D-3).

Klukwan, 96, (fig. D-3).

Kougarok Mountain, 26, (fig. D-2).

Koyukuk-Hughes mining district, 42 , (fig. D-3).

Koyukuk-Nolan mining district, 16, (fig. D-3).

Latouche, Beatson, 80, (fig. D-1).

Liberty Belle, 54, (fig. D-1).

Lik, 1, (fig. D-1).

Livengood-Tolovana mining district, 48 , (fig. D-3).

Lost River, 24, (fig. D-2).

Lucky Shot, 79, (fig. D-3).

McLeod, 124, (fig. D-2).

Mertie Lode, 99, (fig. D-3).

Midas mine, 77, (fig. D-1).

Mike deposit, 90, (fig. D-2).

Mirror Harbor, 102, (fig. D-3).

Misheguk Mountain, 13, (fig. D-3).

Mosquito, Peternie, 56, (fig. D-2).

Mt. Prindle, 50, (fig. D-3).

Nabesna mine, 69, (fig. D-3).

Niblack, 121, (fig. D-1).

Nim prospect, 65, (fig. D-1).

Nimiuktuk River, 126, (fig. D-1).
Nixon Fork, 44, (fig. D-3).

Nome mining district, 30, (fig. D-3).

Nunatak, 97, (fig. D-2).

Omalik, 35, (fig. D-1).

Omar, 7, (fig. D-1).

Orange Hill, 73, (fig. D-2).

Pebble Copper, 129, (fig. D-1).

Placer River, 38, (fig. D-2).

Pleasant Creek, 53, (fig. D-1).

Pogo, 130, (fig. D-3).

Poovookpuk Mountain, 40, (fig. D-2).

Porcupine Lake, 18, (fig. D-2).

Purcell Mountain, 41, (fig. D-2).

Pyramid, 87, (fig. D-2).

Quartz Creek, 37, (fig. D-1).

Quartz Hill, 120, (fig. D-2).

Red Bluff Bay, 109, (fig. D-3).

Red Devil, 83, (fig. D-3).

Red Dog, 2, (fig. D-1).

Red Mountain, 82, (fig. D-3).

Rex deposit, 91, (fig. D-2).

Rock Creek, 31, (fig. D-3).

Rua Cove, 81, (fig. D-1).

Ruby mining district, 46, (fig. D-3).

Ryan Lode, 49b, (fig. D-3).

Salt Chuck, 115, (fig. D-3).

Sheep Creek, 54, (fig. D-1).

Sinuk River region, 29, (fig. D-1).

Slate Creek, 59, (fig. D-3).

Sleitat Mountain, 93, (fig. D-2).

Smucker, 11, (fig. D-1).

Snettisham, 107, (fig. D-3).

Snipe Bay, 113, (fig. D-3).

Solomon mining district, 33, (fig. D-3).

Spirit Mountain, 70, (fig. D-3).

Stampede mine, 62, (fig. D-3).

Story Creek, 5, (fig. D-1).

Sumdum, 106, (fig. D-1).

Sun, 10, (fig. D-1).

Taurus, 57, (fig. D-2).

Three Castle Mountain, 53, (fig. D-1).

Tracy Arm, 108, (fig. D-1).

True North, 49d, (fig. D-3).

Twin Mountain, 51, (fig. D-2).

Union Bay, 116, (fig. D-3).

Valdez Creek district, 66, (fig. D-3).

Vinasale Mountain, 44b, (fig. D-3).

Virginia Creek, 54, (fig. D-1).

Von Frank Mountain, 44c, (fig. D-3).

War Baby, 79, (fig. D-3).

Weasel Mountain, Bee Creek, 89, (fig. D-2),

Whoopee Creek, 6, (fig. D-1).

Willow Creek, 79, (fig. D-3).

Wind River, 19, (fig. D-1).

Windy Creek, 36, (fig. D-2),

Zackly, 67a, (fig. D-1).

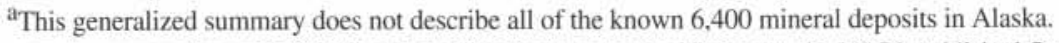
NOTE: In cooperation with DGGS and the Russian Academy of Sciences, the USGS published Open-File Report 93-339 (Nokleberg and others, 1993), Metallogenesis of mainland Alaska and the Russian northeast, which describes 273 lode deposits and 43 significant placer districts in Alaska.
} 


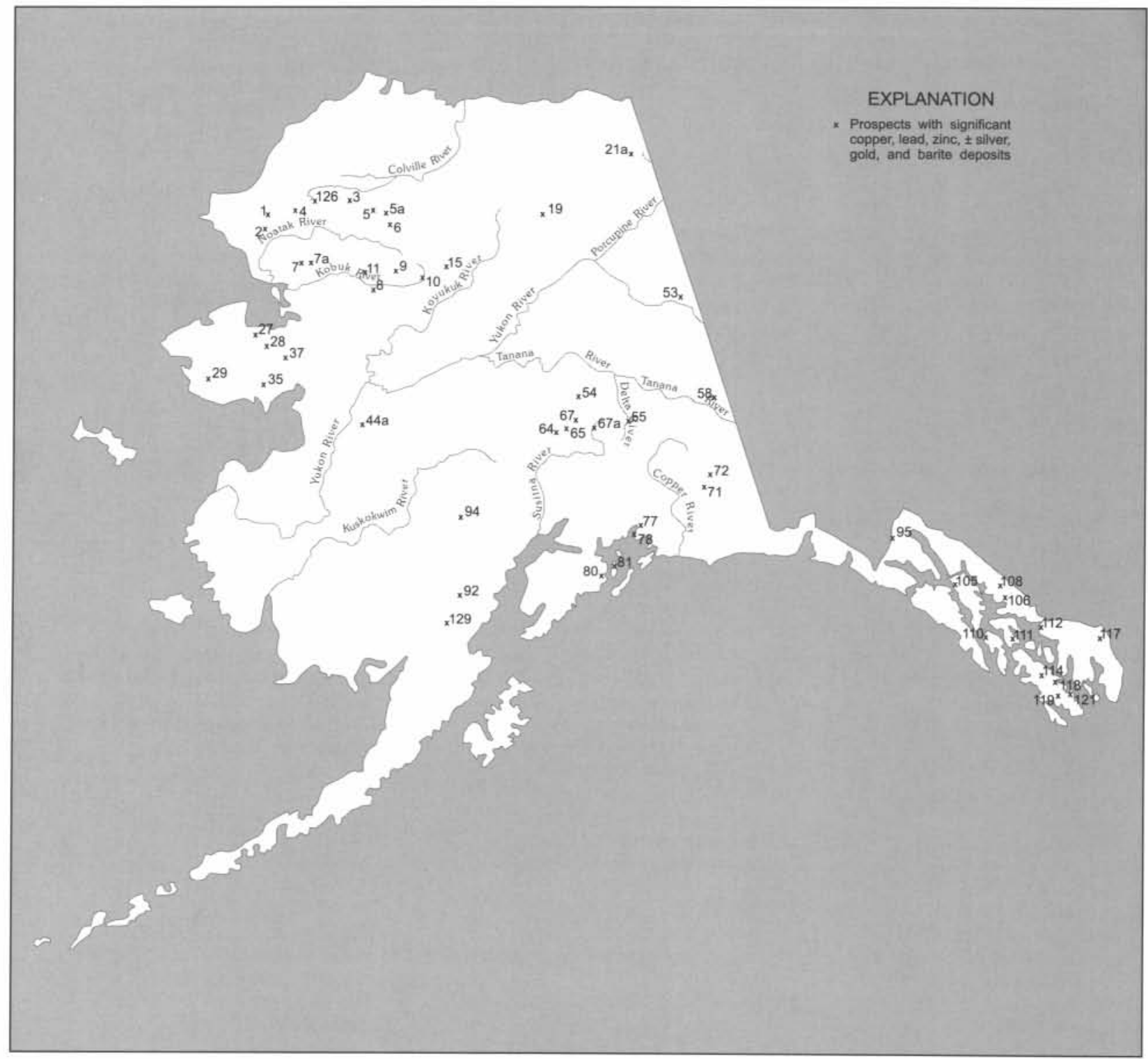

Figure D-1. Significant copper, lead, zinc with credits of silver, gold, and barite deposits in Alaska, 1997.

Map no.

1 Lik-Major strata-bound massive sulfide $(\mathrm{Zn}-\mathrm{Pb}-\mathrm{Ag}-\mathrm{Ba})$ deposit in black shale and chert. Proven reserve (Lik) estimate of 21.77 million tonnes ( 24 million tons) of $9 \% \mathrm{Zn} .3 .1 \% \mathrm{~Pb}$, and $48 \mathrm{~g} /$ tonne (1.4 oz/ton) $\mathrm{Ag}$ (fig. D-1).

2 Red Dog-At least three major strata-bound massive sulfide deposits hosted in Pennsylvanian or Mississippian shale; similar to locality 1. (a) The Main Deposit at Red Dog contains 55.8 million tons of measured and in-dicated ore grading $19.0 \% \mathrm{Zn}$, $5.2 \% \mathrm{~Pb}$, with $2.9 \mathrm{oz} /$ ton $\mathrm{Ag}$. (b) The Aqqaluk Deposit contains 80.4 million tons grading $13.6 \% \mathrm{Zn}, 3.7 \% \mathrm{~Pb}$, and $1.9 \mathrm{oz} /$ ton Ag. (c) The Hilltop Deposit with an inferred reserve is 10.6 million tons grading $17.8 \% \mathrm{Zn}, 5.5 \% \mathrm{~Pb}$, and $3.42 \mathrm{oz} /$ ton $\mathrm{Ag}$. Resource in the Paalaaq deposit is 15.5 million tons of $14.3 \%$ $\mathrm{Zn}, 3.9 \% \mathrm{~Pb}$, and $2.42 \mathrm{oz}$ ton $\mathrm{Ag}$. (fig. D-1).

3 Drenchwater-Mississippian and Pennsylvanian shales and cherts contain three strata-bound base metal occurrences spatially related to acid volcanics. The lowest unit, a siliceous mudstone, contains a $0.6 \mathrm{~m}(2-\mathrm{ft})$ layer with up to $23 \% \mathrm{Zn}$. An overlying gray chert contains up to $11 \% \mathrm{Zn}$ and up to $5 \% \mathrm{~Pb}$ with some $\mathrm{Ag}$ in fracture fillings. At the top of the overlying tuffaceous layer, $\mathrm{Ag}$-bearing $\mathrm{Zn}$ and $\mathrm{Pb}$ mineralization outcrops discontinuously for at least $1,982 \mathrm{~m}$ $(6,500 \mathrm{ft})$, and contains up to $26 \% \mathrm{Zn}$ and $51 \% \mathrm{~Pb}$ in grab samples (fig. D-1).

4 Ginny Creek-Epigenetic, disseminated $\mathrm{Zn}-\mathrm{Pb}-\mathrm{Ag}$ deposits with barite in sandstone and shale of Noatak Sand-stone of Late Devonian through Early Mississippian age. Random grab samples of surface float contain $0.3 \%$ to $3.0 \% \mathrm{Zn}$ and highly variable amounts of $\mathrm{Pb}$ and $\mathrm{Ag}$ (fig. D-1).

5 Story Creek-Epigenetic replacement deposits of $\mathrm{Zn}-\mathrm{Pb}-\mathrm{Ag}-$ $\mathrm{Cu}-\mathrm{Au}$ hosted in brecciated zones in Devonian Kanayut 


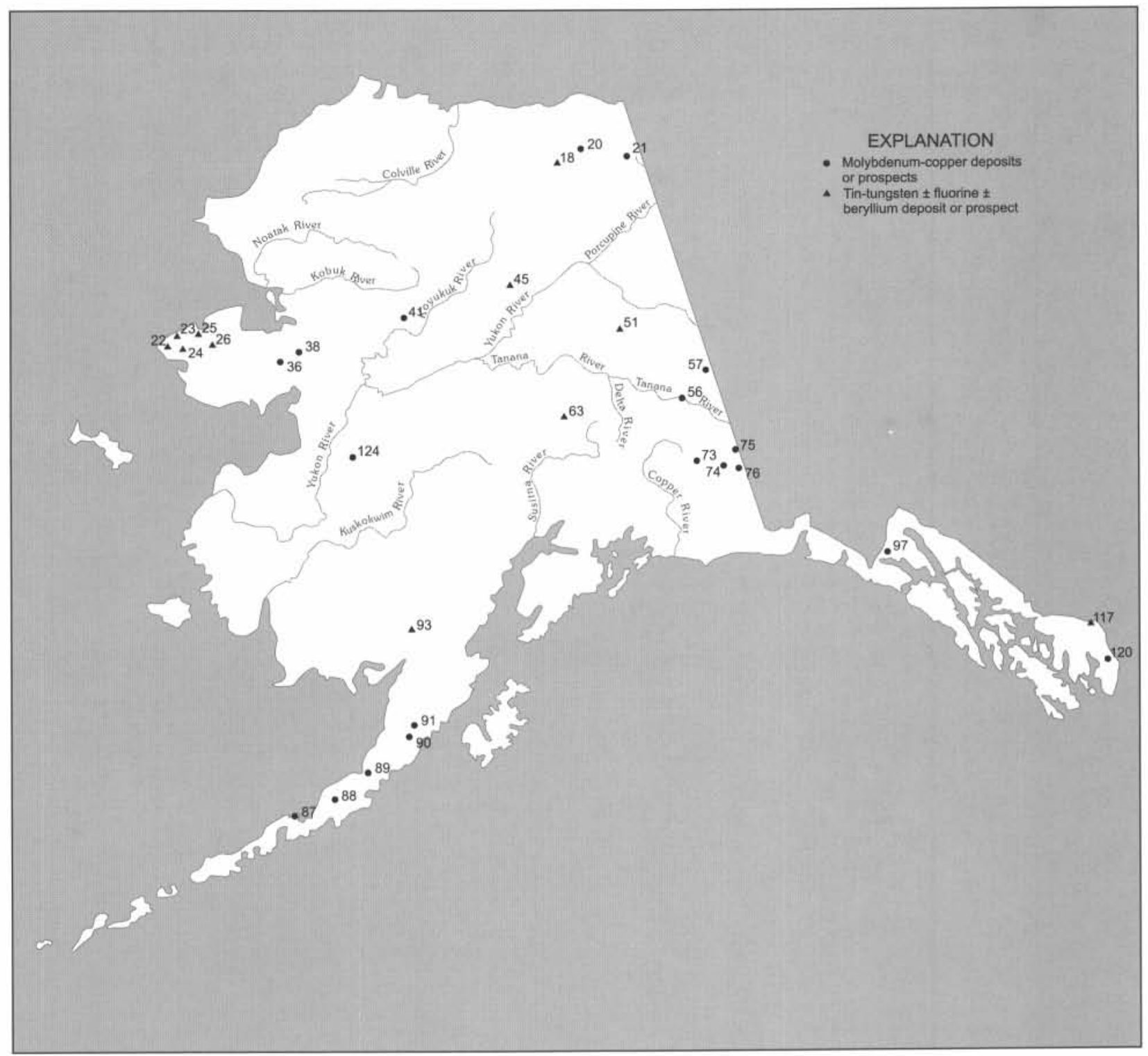

Figure D-2. Significant molybdenum-copper and tin-tungsten with credits of fluorite and beryllium deposits in Alaska, 1997.

Conglomerate or Lower Mississippian Kayak Shale. Grab samples of high-grade material contain up to $0.43 \% \mathrm{Cu}, 34 \%$ $\mathrm{Pb}, 28.8 \% \mathrm{Zn}, 1.4 \mathrm{~g} /$ tonne ( $0.04 \mathrm{oz} /$ ton $) \mathrm{Au}$, and $1,028 \mathrm{~g} /$ tonne (30 oz/ton) $\mathrm{Ag}$ (fig. D-1).

5a Kivliktort Mountain-Mineralized float is widespread on the north flanks of the mountain, apparently spatially related to the contact between shales at the base of the hills and coarsegrained siliceous clastic rocks on the upper slopes. Rock samples containing up to $30 \% \mathrm{Zn}$ have been reported (fig. D-1).

6 Whoopee Creek-Epigenetic replacement deposits of $\mathrm{Zn}-\mathrm{Pb}-$ $\mathrm{Cu}-\mathrm{Ag}-\mathrm{Au}-\mathrm{Cd}$ in breccia zones in Devonian Kanayut Conglomerate or Lower Mississippian Kayak Shale. Ran-dom grab samples of mineralized material contain $0.24 \% \mathrm{Cu}, 0.37 \% \mathrm{Cd}$, $46 \% \mathrm{Zn}, 44 \% \mathrm{~Pb}, 4.8 \mathrm{~g} /$ tonne ( $0.14 \mathrm{oz} / \mathrm{ton}) \mathrm{Au}$, and $507 \mathrm{~g} /$ tonne (14.8 oz/ton) Ag (fig. D-1).

7 Omar-Epigenetic replacement deposits of Paleozoic age; include bedded barite occurrences. Grab samples contain $15.3 \% \mathrm{Cu}, 0.15 \% \mathrm{~Pb}, 0.95 \% \mathrm{Zn}, 0.05 \% \mathrm{Co}$, and $10 \mathrm{~g} /$ tonne
$(0.3 \mathrm{oz} /$ ton $) \mathrm{Ag}$. BLM estimates 35 million tons of $4 \% \mathrm{Cu}$ (fig. D-1)

7a Frost-Possible 8.2 million tonnes ( 9 million tons) barite in pods, lenses, and wavy-banded quartz-calcite-barite veins. Chalcopyrite and galena occur in the veins which cross cut Paleozoic limestone and dolomite for a minimum distance of $1.6 \mathrm{~km}$ (1 mi). Selected samples contain up to $13.2 \% \mathrm{Zn}$ (fig. D1).

8 Bornite-Major strata-bound $\mathrm{Cu}-\mathrm{Zn}$ deposit in brecciated carbonate rock of Devonian age; 4.56 million tonnes ( 5.0 million ton) orebody contains $4.0 \% \mathrm{Cu}$ and accessory $\mathrm{Zn}$ and Co. Larger reserve estimate of 36.2 million tonnes ( 40 million tons) of about $2 \% \mathrm{Cu}$ and undisclosed amount of $\mathrm{Zn}$ and $\mathrm{Co}$. At grade of $1.2 \% \mathrm{Cu}$, reserves are 91 million tonnes (100 million tons) (fig. D-1).

9 Arctic-Major volcanogenic $(\mathrm{Cu}-\mathrm{Zn})$ massive sulfide deposit hosted in sequence of metarhyolite, metatuff, and graphitic schist of Devonian age; indicated reserves of 36.3 million 


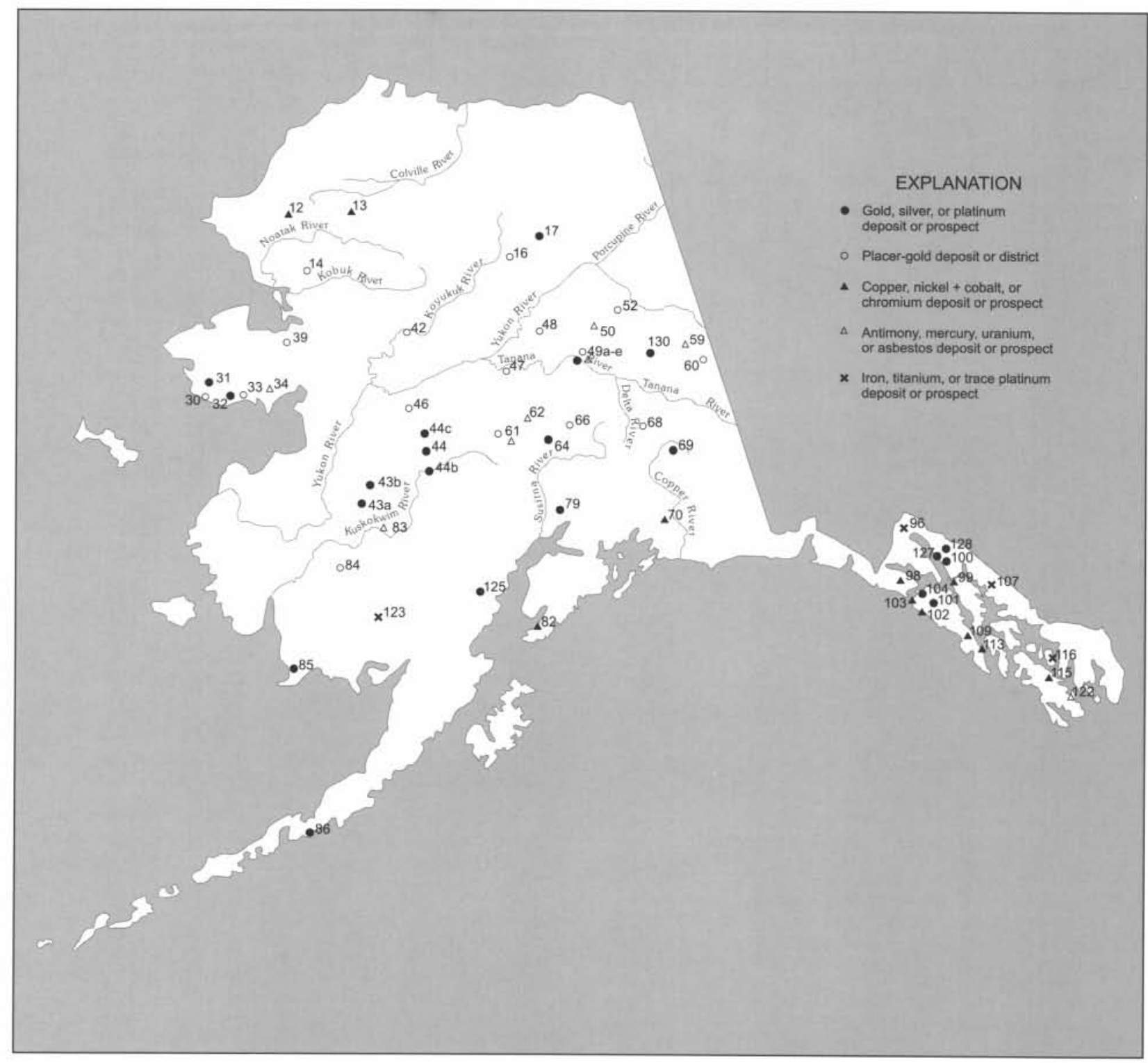

Figure D-3. Significant gold, silver, platinum, and strategic mineral deposits in Alaska, 1997.

tonnes (40 million tons) grade $4.0 \% \mathrm{Cu}, 5.5 \% \mathrm{Zn}, 0.8 \% \mathrm{~Pb}$, $55 \mathrm{~g} /$ tonne ( $1.6 \mathrm{oz} /$ ton $) \mathrm{Ag}$, and $0.69 \mathrm{~g} /$ tonne $(0.02 \mathrm{oz} /$ ton $) \mathrm{Au}$ (fig. D-1).

$10 \mathrm{Sun}-\mathrm{Major}(\mathrm{Cu}-\mathrm{Pb}-\mathrm{Zn}-\mathrm{Ag})$ massive sulfide deposit in sequence of middle Paleozoic metarhyolite and metabasalt. Average grades are 1 to $4 \% \mathrm{~Pb}, 6$ to $12 \% \mathrm{Zn}, 0.5$ to $7 \% \mathrm{Cu}$, 103 to $377 \mathrm{~g} /$ tonne ( 3 to $11 \mathrm{oz} /$ ton) $\mathrm{Ag}$ (fig. D-1).

11 Smucker-Middle Paleozoic volcanogenic massive sulfide deposit; $915 \mathrm{~m}(3,000 \mathrm{ft})$ long and up to $58 \mathrm{~m}$ (190 ft) wide: contains significant tonnage of $\mathrm{Cu}-\mathrm{Pb}-\mathrm{Zn}$ ore that grades $1.5 \%$ $\mathrm{Pb}, 5$ to $10 \% \mathrm{Zn}, 103$ to $343 \mathrm{~g} /$ tonne ( 3 to $10 \mathrm{oz} /$ ton) $\mathrm{Ag}$, with minor Au (fig. D-1).

12 Avan Hills-Disseminated chromite in layered ultramafic rocks; grab samples contain up to $4.3 \% \mathrm{Cr}$ with $0.51 \mathrm{~g} /$ tonne (0.015 oz/ton) PGM (fig. D-3).

13 Misheguk Mountain-Chromite occurrences similar to those in Avan Hills (fig. D-3).
14 Klery Creek-Lode and placer Au deposits worked intermittently from 1909 through 1930s. Total production through 1931, mostly from placer deposits, estimated at $974 \mathrm{~kg}(31,320 \mathrm{oz}) \mathrm{Au}$ (fig. D-3).

15 Ernie Lake (Ann Creek) - Strata-bound massive sulfide occurrence in metarhyolite, metatuff, and marble. Gossan zones strongly anomalous in $\mathrm{Cu}-\mathrm{Pb}-\mathrm{Zn}$ and $\mathrm{Ag}$ (fig. D-1).

16 Koyukuk-Nolan mining district-Major placer Au district: from 1893 to 1995 produced an estimated $10,580 \mathrm{~kg}$ (340,152 oz) Au. Significant deep placer reserves remain (fig. D-3).

17 Chandalar mining district-Major Au producing district; substantial production in excess of $2,000 \mathrm{~kg}(64,367 \mathrm{oz}) \mathrm{Au}$ through 1995 from lode and placer sources; lode Au found in crosscutting quartz veins that intrude schist and greenstone. Active development of placer deposits and lodes in progress. Inferred lode reserves estimated to be 40,800 tonnes 
(45,000 tons) with grade of $69 \mathrm{~g} /$ tonne $(2 \mathrm{oz} /$ ton) $\mathrm{Au}$ (fig. D-3).

18 Porcupine Lake - Stratiform fluorite occurrences and argentiferous enargite, tetrahedrite associated with felsic volcanic rocks of late Paleozoic age. Reported grades of up to $30 \%$ fluorite $\left(\mathrm{CaF}_{2}\right)$ reported, with grab samples of $4.8 \% \mathrm{Cu}$ (fig. D-2).

19 Wind River-Strata-bound $\mathrm{Pb}-\mathrm{Zn}$ massive sulfide prospects; reported grades of up to $5 \% \mathrm{~Pb}$ (fig. D-1).

20 Esotuk Glacier-Disseminated $\mathrm{Mo}-\mathrm{Sn}-\mathrm{W}-\mathrm{Pb}-\mathrm{Zn}$ mineralization in skarns associated with Devonian(?) schistose quartz monzonite. Grab samples contain up to $0.08 \% \mathrm{Sn}$ and $0.15 \% \mathrm{~W}$ (fig. D-2).

21 Bear Mountain-Major stockwork Mo-W-Sn occurrence in intrusive breccia. Rock samples containing up to $0.8 \%$ Mo and $0.6 \% \mathrm{~W}$ occur within a 14 ha ( 35 acre) area where soil samples average more than $0.2 \% \mathrm{MoS}_{2}$, and an adjacent 10 ha (25 acre) area where rubble contains wolframite has soils averaging greater than $0.12 \% \mathrm{WO}_{3}$. Rubble crop in this area indicates a Tertiary porphyry system as the source of the Mo and W (fig. D2).

21 a Galena Creek-Steeply dipping veins contain up to $21 \% \mathrm{Cu}$, $3.5 \% \mathrm{Zn}$, and $1.3 \% \mathrm{~Pb}$ with $189 \mathrm{~g} /$ tonne $(5.5 \mathrm{oz} / \mathrm{ton}) \mathrm{Ag}$ on the east side of the creek, and on the ridge west of the creek a large area of disseminated mineralization and veinlets contains predominantly $\mathrm{Zn}$ (fig. D-1).

22 Cape Creek-Major placer Sn producer. More than 454 tonnes (500 tons) Sn produced from 1935 to 1941; from 1979 to 1990 , produced 940 tonnes (1,040 tons) Sn. Derived from Cape Mountain in contact zone of Cretaceous granite and limestone (fig. D-2),

23 Buck Creek-Major placer Sn producer. More than 998 tonnes (1,100 tons) Sn produced from 1902 to 1953 (fig. D-2).

24 Lost River-Major Sn, fluorite, W, and Be deposit associated with Cretaceous $\mathrm{Sn}$ granite system. More than 317 tonnes (350 tons) Sn produced from skarn and greisen lode sources. Measured reserves amount to 22.3 million tonnes (24.6 million tons) that grade $0.15 \% \mathrm{Sn}, 16.3 \% \mathrm{CaF}_{2}$, and $0.03 \% \mathrm{WO}_{3}$, based on $13,720 \mathrm{~m}(45,000 \mathrm{ft})$ of diamond drilling (fig. D-2).

25 Ear Mountain-Placer $\mathrm{Sn}$ district and $\mathrm{Sn}-\mathrm{Cu}-\mathrm{Au}-\mathrm{Ag}-\mathrm{Pb}-\mathrm{Zn}$ skarn mineralization of Cretaceous age. Area also anomalous in U (fig. D-2).

26 Kougarok Mountain-Sn deposit hosted in quartz-tourmalinetopaz greisen of Cretaceous age. Grades may average $0.5 \% \mathrm{Sn}$ and $0.01 \% \mathrm{Ta}$ and $\mathrm{Nb}$, but a high grade resource of 136,050 tonnes $(150,000$ tons) grading $1 \%+\mathrm{Sn}$ has been identified, with incrementally higher tonnage at lower grades (fig. D-2).

27 Hannum - Stratiform, carbonate-hosted $\mathrm{Pb}-\mathrm{Zn}-\mathrm{Ag}$ massive sulfide deposit of mid-Paleozoic age in heavily oxidized zone that ranges from 9 to $46 \mathrm{~m}$ ( 30 to $150 \mathrm{ft}$ ) thick. Mineralized zone reported to assay up to $10 \% \mathrm{~Pb}, 2.2 \% \mathrm{Zn}, 1.4 \mathrm{~g} /$ tonne $(0.04$ $\mathrm{oz} /$ ton) $\mathrm{Au}$, and $60.3 \mathrm{~g} /$ tonne (1.76 oz/ton) Ag (fig. D-1).

28 Independence Creek- $\mathrm{Pb}-\mathrm{Zn}-\mathrm{Ag}$ massive sulfide deposit; high-grade ore shipped in 1921 contained $30 \% \mathrm{~Pb}, 5 \% \mathrm{Zn}$, up to $5,141 \mathrm{~g} /$ tonne ( $150 \mathrm{oz} /$ ton) $\mathrm{Ag}$. Mineralization restricted to shear zone in carbonates (fig. D-1).

29 Sinuk River region-Several $\mathrm{Pb}-\mathrm{Zn}-\mathrm{Ag}-\mathrm{Ba}-\mathrm{F}$ bearing massive sulfide deposits and layered $\mathrm{Fe}$ deposits in carbonate and metavolcanic rocks of Nome Group. Mineralized zones extend for over $2,440 \mathrm{~m}$ ( $8,000 \mathrm{ft})$ along strike (fig. D-1).
30 Nome mining district-Major placer Au producer. Production from $1897-1995$ in excess of $151,600 \mathrm{~kg}(4,874,449 \mathrm{oz}) \mathrm{Au}$ all from placers. Sporadic Sb and W production in past (fig. D-3).

31 Rock Creek-About 10.0 million tons grading $2.5 \mathrm{~g} /$ tonne $(0.072 \mathrm{oz} /$ ton $) \mathrm{Au}$ in vein swarms and stringers in an area $457 \mathrm{~m}$ $(1.500 \mathrm{ft})$ long. $152 \mathrm{~m}(500 \mathrm{ft})$ maximum width and $91 \mathrm{~m}$ $(300 \mathrm{ft})$ deep (fig. D-3).

32 Big Hurrah-Epigenetic vein deposit in black slate and metasedimentary rocks of the Soloman schist. Deposit contains some W mineralization and has produced over $840 \mathrm{~kg}$ (27,000 oz) Au from nearly 45,350 tonnes (50,000 tons) milled ore. Proven, inferred, and indicated reserves total 94,328 tonnes ( 104,000 tons) that grade $21 \mathrm{~g} /$ tonne $(0.61 \mathrm{oz} / \mathrm{ton}) \mathrm{Au}, 19 \mathrm{~g} /$ tonne ( $0.55 \mathrm{oz} /$ ton) $\mathrm{Ag}$, and credits of $\mathrm{WO}_{3}$ (fig. D-3).

33 Solomon and Council mining districts-Major placer $\mathrm{Au}$ districts; produced over $32,550 \mathrm{~kg}(1.046,513 \mathrm{oz})$ through 1995. Three structurally controlled Au deposits in Bluff area-Daniels Creek, Saddle, and Koyana Creek - contain minimum inferred reserves of 5.9 million tonnes ( 6.5 million tons) grading $3.4 \mathrm{~g} /$ tonne (0.1 oz/ton) Au (fig. D-3).

34 Kachauik-U prospect in Cretaceous alkalic intrusive rocks. Highly anomalous geochemical values and $U$ concentrations of 1,000 ppm reported (fig. D-3).

35 Omalik - Vein-type $\mathrm{Pb}-\mathrm{Zn}-\mathrm{Ag}$ massive sulfide prospect in Paleozoic carbonate rocks; from 1881 to 1900 , produced 363 tonnes ( 400 tons) of $\mathrm{Pb}-\mathrm{Zn}$ ore that averaged about $10 \% \mathrm{~Pb}$ and 1,371 g/tonne ( $40 \mathrm{oz} /$ ton) $\mathrm{Ag}$. Grades of oxidized $\mathrm{Zn}$ ore reported to be up to $34 \% \mathrm{Zn}$ (fig. D-1).

36 Windy Creek-Disseminated $\mathrm{Mo}-\mathrm{Pb}-\mathrm{Zn}$ mineralization in quartz veins and skarns with reported values as high as $0.15 \%$ Mo (fig. D-2).

37 Quartz Creek-Significant $\mathrm{Pb}-\mathrm{Zn}-\mathrm{Ag}$ mineralization; reported grades of $15 \%$ combined $\mathrm{Pb}-\mathrm{Zn}$ and $343 \mathrm{~g} /$ tonne (10 oz/ton) $\mathrm{Ag}$ (fig. D-1).

38 Placer River-Significant Mo-F mineralization disseminated in intrusive rocks. Reported values of $0.2 \%$ Mo (fig. D-2).

39 Fairhaven/Inmachuk district-Placer deposits with $10,812 \mathrm{~kg}$ (347,671 oz) production from 1902-1995; significant reserves remaining in a large ancestral channel system. Large base metal sulfide concentrations and $\mathrm{U}$ values in concentrates (fig. D-3).

40 Poovookpuk Mountain-Porphyry Mo mineralization. Reported grades of up to $0.25 \%$ Mo (fig. D-2).

41 Purcell Mountain-Mo and Ag occurrences associated with Cretaceous alkalic igneous plutons, alaskite, and bostonite dikes (fig. D-2).

42 Koyukuk-Hughes mining district-Production of $7,211 \mathrm{~kg}$ (231.888 oz) Au from 1930 to 1995 , mainly from Alaska Gold Company dredge at Hogatza; dredge reactivated in 1981, but deactivated in 1984, and reactivated again in 1990. Nonfloat mechanized operation on Utopia Creek produced significant amount of placer Au from 1930 to 1962 (fig. D-3).

43a Iditarod district-Major placer Au district; produced $48,560 \mathrm{~kg}(1,561,524 \mathrm{oz})$ Au through 1995. Significant reserves of lode $\mathrm{Au}$ and lode $\mathrm{W}$ at Golden Horn deposit Chicken Mountain, and other known lodes in region associated with shear zones and monzonite intrusive rocks of Late Cretaceous age (fig. D-3).

43b Innoko-Tolstoi mining district-Major placer Au district with significant lode $\mathrm{Au}-\mathrm{Sb}-\mathrm{Hg}$ potential; lode sources for placers are volcanic-plutonic complexes of Late Cretaceous and dike swarms that intrude Mesozoic flysch; mining district produced 
$21,965 \mathrm{~kg}(706,267 \mathrm{oz})$ Au through 1995 almost all from placer deposits. New discovery on Vinasale Mountain south of McGrath is Au-polymetallic deposit in monzonite stock (fig. D-3).

44 Nixon Fork-Promising Au-Cu deposits; Nixon Fork mine produced $1.851 \mathrm{~kg}(59.500 \mathrm{oz})$ Au from Late Cretaceous skarns associated with quartz monzonite-Devonian limestone contact zones. Underground mining resumed in October 1995 (fig. D-3).

44a Illinois Creek - Near-surface geologic resource is 5.76 million tonnes ( 6.35 million tons) at $2.4 \mathrm{~g} /$ tonne $(0.070 \mathrm{oz} / \mathrm{ton})$ gold and $51.47 \mathrm{~g} /$ tonne ( $1.5 \mathrm{oz} /$ ton) silver (fig. D-1).

44b Vinasale Mountain - Intrusive-hosted gold deposit. Au mineralization is associated with arsenopyrite and pyrite and within zones of phyllic and silicic alteration hosted within a $69 \mathrm{Ma}$ quartz monzonite stock. Both disseminated and veinlet mineralization exist. An inferred reserve of 10.3 million tonnes (11.35 million tons) grading $2.4 \mathrm{~g} /$ tonne $(0.07 \mathrm{oz} /$ ton $)$ has been identified by drilling (fig. D-3).

44c Von Frank Mountain-Au and very weak Cu mineralization are associated with chalcopyrite, pyrite, and rare molybdenite within a zone of quartz stockwork veining hosted in a $69 \mathrm{Ma}$ quartz-diorite stock. The stock is a cupola of the larger Von Frank Pluton. Drill intercepts include thicknesses up to 429 feet with an average grade of $0.013 \mathrm{oz} /$ ton $\mathrm{Au}$. Higher grade intercepts include $0.035 \mathrm{oz} /$ ton Au up to $135 \mathrm{ft}$. (fig. D-3).

45 Bonanza Creek-Skarn-type W mineralization along intrusive contact; no published information available (fig. D-2).

46 Ruby mining district-Placer Au-Sn district; produced more than $14,830 \mathrm{~kg}(476,751 \mathrm{oz})$ Au from 1931 to 1995; mining district also contains $\mathrm{Pb}-\mathrm{Ag}$ prospects with grades reportedly as high as $2,811 \mathrm{~g} /$ tonne $(82 \mathrm{oz} /$ ton) $\mathrm{Ag}$ (fig. D-3).

47 Hot Springs mining district-Placer Au-Sn district; produced more than $17,685 \mathrm{~kg}(568,632 \mathrm{oz}) \mathrm{Au}$ and over $326,590 \mathrm{~kg}$ $(720,000 \mathrm{lb})$ cassiterite through 1995. Includes Eureka and Tofty subdistricts (fig. D-3).

48 Livengood-Tolovana mining district-Placer Au district; produced more than $15,440 \mathrm{~kg}(496,417 \mathrm{oz})$ Au since discovery in 1914 to 1995. Substantial reserves remain mainly on Livengood Bench, a Pliocene ancestral channel (fig. D-3).

49 Fairbanks mining district-Nationally ranked Au-producing district; largest producer in Alaska. Produced about $249,500 \mathrm{~kg}$ (8,022,434 oz) Au from placer deposits (1902-1995). Major lode $\mathrm{Au}$ and lode $\mathrm{Sb}$ producer; produced more than $9,472 \mathrm{~kg}$ (304,548 oz) Au and over 1.8 million $\mathrm{kg}$ (4 million lb) Sb from veins and shear zones through 1990. Production of W exceeded 4,000 short ton units since 1915 , all derived from skarn near Cretaceous quartz monzonite (fig. D-3).

49a Fort Knox-Disseminated Au deposit within granodiorite/ quartz monzonite pluton near Fairbanks. Proven and probable reserves, open at depth, are $128,000 \mathrm{~kg}(4,200,000 \mathrm{oz})$ of gold in 158.3 million tonnes (174.5 million tons) of rock. Fairbanks Gold Mining Inc. mined 366,223 ounces in 1997 at a cash cost of $\$ 170 / \mathrm{oz}$ (fig. D-3).

49b Ryan Lode-Based on a $0.51 \mathrm{~g} /$ tonne $(0.015 \mathrm{oz} /$ ton $)$ cutoff, total reserves in the metasediment-hosted Ryan Lode and subparallel igneous-hosted Curlew Shear are $25,573 \mathrm{~kg}$ $(822,200 \mathrm{oz}$ ) of $\mathrm{Au}$ in 13.2 million tonnes ( 14.6 million tons) of rock. A geologic resource of about $74.468 \mathrm{~kg}$ ( 2.4 million oz) occurs within the total shear zone system (fig. D-3).

49c Grant Mine-A series of subparallel Au-bearing quartz veins in the schist and quartzite of Ester Dome based on exploration in 1990. Indicated reserves on one vein system, the O'Dea, are 192,285 tonnes ( 212,000 tons) of $12 \mathrm{~g} /$ tonne $(0.36 \mathrm{oz} /$ ton $) \mathrm{Au}$. Other similar vein systems have been identified within the property (fig. D-3).

49d True North-Au occurs in siderite-quartz veins in carbonaceous quartzite and schist within a terrane containing eclogitic rocks. The mineral inventory is 16.5 million tonnes (18.2 million tons) grading $2.47 \mathrm{~g} /$ tonne $\mathrm{Au}(0.072 \mathrm{oz} / \mathrm{ton}) \mathrm{Au}$ for a contained $40,869 \mathrm{~kg}(1,314,000 \mathrm{oz})$ Au. Further exploration is expected to increase the reserve base (fig. D-3).

$49 \mathrm{e}$ Dolphin-Recently recognized mineralized intermediate intrusion contains anomalous $\mathrm{Au}, \mathrm{As}, \mathrm{Bi}$ and $\mathrm{Sb}$. Discovery hole in 1995 intercepted $100 \mathrm{~m}$ of $1.68 \mathrm{~g} /$ tonne ( $330 \mathrm{ft}$ of $0.049 \mathrm{oz} /$ ton) gold (fig. D-3).

50 Mt. Prindle-Significant U-rare-earth mineralization in Mesozoic alkaline igneous rocks. Rock geochemical values of up to $0.7 \% \mathrm{U}$; up to $15 \%$ rare-earth elements reported (fig. D-3).

51 Twin Mountain-Significant W mineralization associated with skarn development along contact zone of quartz monzonite stock of Cretaceous age (fig. D-2).

52 Circle mining district-Currently one of Alaska's largest producing placer Au districts; produced 31,960 kg (1,027,607 oz) Au since discovery in 1893 to 1995 . Has significant potential for $\mathrm{Sn}, \mathrm{W}$, and Au mineralization from variety of lode sources (fig. D-3).

53 Three Castle Mountain, Pleasant Creek, Casca VABMStrata-bound $\mathrm{Pb}-\mathrm{Zn}$ massive sulfide mineralization. Reported grades of up to $17 \% \mathrm{Zn}$ and $2 \% \mathrm{~Pb}$ (fig. D-1).

54 Bonnifield district massive sulfide deposits (Anderson Mountain, Dry Creek, Sheep Creek, Virginia Creek, BT, Liberty Belle)-Significant volcanogenic $\mathrm{Cu}-\mathrm{Pb}-\mathrm{Zn}-\mathrm{Ag}$ massive sulfide deposits of Devonian to Mississippian age in Bonnifield mining district. Potential for high-grade deposits reported. Includes Liberty Bell strata-bound Au-B deposit and mineralization in Sheep Creek; latter contains $\mathrm{Sn}$ as well as base metals (fig. D-1).

55 Delta massive sulfide belt - Contains at least 30 known volcanogenic massive sulfide deposits and occurrences. Grades from 0.3 to $1.1 \% \mathrm{Cu}, 1.7$ to $5.7 \% \mathrm{Zn}, 0.5$ to $2.3 \% \mathrm{~Pb}, 24$ to 69 $\mathrm{g} /$ tonne $(0.7$ to $2.0 \mathrm{oz} /$ ton $) \mathrm{Ag}$, and 0.61 to $2.1 \mathrm{~g} /$ tonne $(0.018$ to $0.061 \mathrm{oz} / \mathrm{ton}$ ) Au; estimated potential reserve of 34.6 million tonnes (40 million tons) for all deposits (fig. D-1).

56 Mosquito, Peternie-Porphyry Mo prospects of early Tertiary age; reported grades of up to $0.17 \%$ Mo (fig. D-2).

57 Taurus-Significant major porphyry $\mathrm{Cu}-\mathrm{Au}$ prospect of Paleocene age. East Taurus Zone contains inferred reserves of 126 million tonnes ( 140 million tons) grading about $0.30 \% \mathrm{Cu}$ and $0.34 \mathrm{~g} /$ tonne $(0.01 \mathrm{oz} /$ ton) $\mathrm{Au}$, and $0.03 \%$ Mo (fig. D-2).

58 Big Creek/Ladue - Strata-bound $\mathrm{Pb}-\mathrm{Zn}-\mathrm{Ag}$ massive sulfide prospects in metavolcanic rocks (fig. D-1).

59 Slate Creek-At least 50 million tonnes ( 55 million tons) of $6.3 \%$, high-quality chrysotile asbestos in serpentinized ultramafic rocks of Permian(?) age (fig. D-3).

60 Fortymile mining district-Major placer Au district. Produced over $16,640 \mathrm{~kg}(534,974 \mathrm{oz})$ placer and very minor lode $\mathrm{Au}$ since discovery in 1883 to 1995 , the longest continuous production of gold (113 years) of any Alaskan mining district (fig. D-3).

61 Kantishna mining district-Major placer $\mathrm{Au}$ and lode $\mathrm{Ag}-$ $\mathrm{Au}-\mathrm{Pb}-\mathrm{Zn}-\mathrm{Sb}-\mathrm{W}$ district. Produced $3,089 \mathrm{~kg}(99,307 \mathrm{oz})$ placer and lode $\mathrm{Au}$, about $9,549 \mathrm{~kg}(307,000 \mathrm{oz})$ lode $\mathrm{Ag}$, and 
2.3 million $\mathrm{kg}$ ( 5 million $\mathrm{lb}$ ) Sb from shear zones and vein deposits hosted in metamorphic units of Yukon-Tanana terrane. Nearly 90 lode deposits have been identified; potential exists for significant $\mathrm{Ag}-\mathrm{Au}-\mathrm{Pb}-\mathrm{Zn}$ resources. Metalliferous strata-bound base metal deposits occur in schist and quartzite (fig. D-3).

62 Stampede mine-Major Sb deposit; produced more than 1.42 million $\mathrm{kg}$ ( 3.5 million $\mathrm{lb}$ ) Sb from large shear zone in polymetamorphic rocks of Yukon-Tanana terrane (fig. D-3).

63 Coal Creek-Greisen-hosted Sn-Cu-W deposit in "McKinley" age pluton (55 million-year-old). Reported reserves of 4.54 million tonnes ( 5 million tons) of ore that grade $0.28 \% \mathrm{Sn}$ and $0.3 \% \mathrm{Cu}$ with credits of $\mathrm{W}, \mathrm{Ag}$, and $\mathrm{Zn}$ (fig. D-2).

64 Golden Zone mine-Major $\mathrm{Au}-\mathrm{Cu}$-Ag deposits in Late Cretaceous breccia pipe and skarn deposits. Produced more than $49 \mathrm{~kg}(1,581 \mathrm{oz}) \mathrm{Au}, 268 \mathrm{~kg}(8,617 \mathrm{oz}) \mathrm{Ag}$, and 19,051 kg $(42,000 \mathrm{lb}) \mathrm{Cu}$. On the basis of recent (1994) drilling, the Pipe, Bunkhouse, and Copper King deposits contain 12.1 million tonnes ( 13.3 million tons) grading $3.25 \mathrm{~g} /$ tonne $(0.095 \mathrm{oz} /$ ton) gold (figs. D-1 and D-3).

65 Nim Prospect-Porphyry $\mathrm{Cu}-\mathrm{Ag}-\mathrm{Au}$ deposit of Late Cretaceous age. Reported grades of up to $5.0 \% \mathrm{Cu}$ and $309 \mathrm{~g} /$ tonne ( $9 \mathrm{oz} /$ ton) $\mathrm{Ag}$ (fig. D-1).

66 Valdez Creek district-About $15,813 \mathrm{~kg}(508,454 \mathrm{oz}) \mathrm{Au}$ production through 1995. Cambior Alaska Inc., the largest placer mine in Alaska, operated in this district until September 1995 (fig. D-3).

67 Denali Prospect-At least six small, strata-bound $\mathrm{Cu}$ lodes in volcanic sedimentary rocks of Triassic age that may contain 4.54 million tonnes ( 5 million tons) ore that grade about $2 \% \mathrm{Cu}$ with credits of $\mathrm{Ag}$ (fig. D-1).

67a Zackly-Disseminated copper and gold in a garnet-pyroxene skarn and marble. Reserves are estimated at 1.27 million tonnes ( 1.4 million tons) grading 2.6 percent $\mathrm{Cu}$ and $6.0 \mathrm{~g} /$ ton (0.175 oz/ton) Au (fig. D-1).

68 Chistochina-Porphyry Cu prospects of Tertiary age and placer Au district; produced more than $5,637 \mathrm{~kg}(181,261 \mathrm{oz})$ $\mathrm{Au}$ and small amount Pt from placer deposits (fig. D-3).

69 Nabesna mine - Classic high-grade Au skarn that envelopes quartz diorite of Jurassic(?) age; produced over $2,068 \mathrm{~kg}$ (66,500 oz) Au from about 79,816 tonnes ( 88,000 tons) of ore from 1930 to 194 I (fig. D-3).

70 Spirit Mountain-Massive and disseminated $\mathrm{Cu}-\mathrm{Ni}$ mineralization in mafic-ultramafic complex (fig. D-3).

71 Kennecott deposits-Major stratiform $\mathrm{Cu}-\mathrm{Ag}$ massive sulfide deposits localized near contact between Chitistone Limestone and Nikolai Greenstone of Triassic age; contained some of highest grade $\mathrm{Cu}$ lodes mined in North America. From 1911 to 1938, produced more than 544 million $\mathrm{kg}$ ( 1.2 billion $\mathrm{lb}$ ) $\mathrm{Cu}$ and $311,028 \mathrm{~kg}$ ( 10 million $\mathrm{oz}) \mathrm{Ag}$ from 4.35 million tonnes (4.8 million tons) ore. Some reserves remain (fig. D-1).

72 Binocular and other prospects-Kennecott-type $\mathrm{Cu}-\mathrm{Ag}$ massive sulfide deposits (fig. D-1).

73 Bond Creek-Orange Hill-Two major porphyry $\mathrm{Cu}-\mathrm{Mo}$ deposits of Late Cretaceous age; reported inferred reserves of 770 million tonnes ( 850 million tons) ore that grade 0.3 to $0.5 \%$ $\mathrm{Cu}$ and $0.03 \%$ Mo (fig. D-2).

74 Carl Creek-Porphyry Cu prospect in altered intrusive complex; similar to locality 73 (fig. D-2).

75 Baultoff-Porphyry Cu prospect in altered intrusive rocks; inferred reserves of 132 million tonnes ( 145 million tons) of $0.20 \% \mathrm{Cu}$ similar to locality 73 (fig. D-2).
76 Horsfeld-Porphyry Cu prospect; similar to locality 73 (fig. D-2).

77 Midas mine - Significant strata-bound $\mathrm{Cu}(\mathrm{Ag}-\mathrm{Au}-\mathrm{Pb}-\mathrm{Zn})$ massive sulfide deposit in volcanic sedimentary rocks of Tertiary Orca Group. Produced more than 1.5 million $\mathrm{kg}$ ( 3.3 million $\mathrm{lb}$ ) $\mathrm{Cu}$ from 44,760 tonnes ( 49,350 tons) ore (fig. D-1).

78 Ellamar-Strata-bound $\mathrm{Cu}-\mathrm{Zn}$-Au massive sulfide deposit in sediment of Eocene(?) Orca Group. Produced more than 7.3 million $\mathrm{kg}$ ( 16 million lb) $\mathrm{Cu}, 1,596 \mathrm{~kg}(51,307 \mathrm{oz}) \mathrm{Au}$, and $5,960 \mathrm{~kg}(191,615 \mathrm{oz}) \mathrm{Ag}$ from about 273,764 tonnes (301,835 tons) ore (fig. D-1).

79 Willow Creek, Independence, Lucky Shot, War BabyMajor lode $\mathrm{Au}(\mathrm{Ag}-\mathrm{Cu}-\mathrm{Pb}-\mathrm{Zn}-\mathrm{Mo})$ in veins that cut Mesozoic quartz diorite. Produced more than $18,860 \mathrm{~kg}(606,400 \mathrm{oz}) \mathrm{Au}$ from lode sources and about $1,729 \mathrm{~kg}(55,600 \mathrm{oz}) \mathrm{Au}$ from associated placer deposits (fig. D-3).

80 Latouche, Beatson-Major strata-bound $\mathrm{Cu}-\mathrm{Zn}-\mathrm{Ag}$ massive sulfide deposits in Orca Group sedimentary rocks and mafic volcanic rocks. Produced more than 93 million $\mathrm{kg}$ ( 205 million lb) $\mathrm{Cu}$ from 5.4 million tonnes ( 6 million tons) ore. Inferred reserves of 4.53 million tonnes ( 5 million tons) ore that grade $1 \% \mathrm{Cu}, 1.5 \% \mathrm{~Pb}+\mathrm{Zn}$ (fig. D-1).

81 Rua Cove - Major strata-bound $\mathrm{Cu}-\mathrm{Zn}$ massive sulfide deposit in complex ore shoots enclosed in mafic volcanic rocks of Orca Group. Reported reserves of over 1 million tonnes ( 1.1 million tons) ore that grade $1.25 \% \mathrm{Cu}$ (fig. D-1).

82 Red Mountain and Claim Point-Significant $\mathrm{Cr}$ occurrence associated with layered ultramafic complexes of Tertiary age at Red Mountain near Seldovia. More than 35,419 tonnes (39,951 tons) metallurgical-grade ore shipped through 1976; huge low-grade $\mathrm{Cr}$ resource may remain, of which 27 million tonnes (30 million tons) grade $5.1 \% \mathrm{Cr}_{2} \mathrm{O}_{3}$ (fig. D-3).

83 Red Devil-Major $\mathrm{Hg}-\mathrm{Sb}$ deposit; high-grade epithermal $\mathrm{Hg}$ $\mathrm{Sb}$ deposit hosted in shear zones in Kuskokwim Group sedimentary rocks. More than 1.24 million $\mathrm{kg}$ (35,000 flasks) $\mathrm{Hg}$ produced from 68,025 tonnes (75,000 tons) ore (fig. D-3).

84 Donlin Creek-Aniak district-Significant placer Au district. Aniak mining district produced $17,680 \mathrm{~kg}(568,601 \mathrm{oz}) \mathrm{Au}$ from placer deposits, mainly from the Nyac and Donlin Creek areas. Gold-polymetallic deposits hosted in granite porphyry dikes and sills of Donlin Creek area recently estimated to contain 61 million tonnes ( 67 million tons) grading $3.4 \mathrm{~g} /$ tonne $(0.099 \mathrm{oz} /$ tonne) gold (fig. D-3).

85 Goodnews Bay-Major placer Pt district; estimated to have produced over $17,261 \mathrm{~kg}(555,000 \mathrm{oz})$ refined PGE metals from 1934 to 1976; one of the largest known PGE metal resources in United States. Possible resources of 45 million $\mathrm{m}^{3}$ ( 60 million $\mathrm{yd}^{3}$ ) of deep, PGE-bearing gravels remain. Lode source believed to be Alaskan-type zoned ultramafic complex of Jurasssic or Cretaceous age. Possible significant offshore placer potential (fig. D-3).

86 Apollo-Sitka mines-Major lode Au deposits: produced more than $3.347 \mathrm{~kg}(107.600 \mathrm{oz})$ Au from ore that averaged about 7.5 $\mathrm{g} /$ tonne $(0.22 \mathrm{oz} /$ ton $) \mathrm{Au}$. Inferred reserves are 678,440 tonnes ( 748,000 tons) grading $26 \mathrm{~g} /$ tonne $(0.76 \mathrm{oz} / \mathrm{ton}) \mathrm{Au}, 74 \mathrm{~g} /$ tonne ( $2.16 \mathrm{oz} /$ ton) $\mathrm{Ag}$, with base metal credits (fig. D-3).

87 Pyramid-Late Tertiary porphyry Cu-Mo deposit; inferred reserves of 113 million tonnes ( 125 million tons) ore that grade $0.4 \% \mathrm{Cu}$ and $0.03 \%$ Mo reported (fig. D-2).

88 Ivanof-Late Tertiary porphyry Cu prospect; grades of up to $0.72 \% \mathrm{Cu}$ reported. Potential for large tonnages (fig. D-2). 


\section{Appendix $D$}

89 Weasel Mountain, Bee Creek-Porphyry Cu-Mo prospect of late Tertiary to Quaternary age; grades of up to $0.48 \% \mathrm{Cu}$ and $0.035 \%$ Mo reported. Potential for moderate tonnages of lowgrade mineralization (fig. D-2).

90 Mike deposit-Porphyry Mo prospect of late Tertiary age; grades of up to $0.21 \%$ Mo reported. Potential for large tonnages of low-grade Mo mineralization (fig. D-2).

91 Rex deposit-Porphyry Cu prospect similar to locality 90; grades of up to $0.3 \% \mathrm{Cu}$ reported. Potential for moderate reserves of low-grade mineralization (fig. D-2).

92 Kasna Creek-Major stratiform $\mathrm{Cu}-\mathrm{Pb}-\mathrm{Zn}$ and skarn-sulfide deposits of Mesozoic age in mafic, volcanic, and sedimentary rocks; reported reserves of over $9,070,000$ tonnes ( 10 million tons) ore that grade more than $1 \% \mathrm{Cu}$ (fig. D-1).

93 Sleitat Mountain-High-grade east-west-trending, Sn-W-Ag topaz-quartz greisen system hosted in 59-million-year-old old binary granite and in hornfels. Zone up to $1,915 \mathrm{~m}(3,000 \mathrm{ft})$ long and $152 \mathrm{~m}(500 \mathrm{ft})$ wide. One drill-hole showed $26 \mathrm{~m}$ $(85 \mathrm{ft})$ of $1.8 \% \mathrm{Sn}$, and $0.4 \% \mathrm{~W}$. Inferred resources are 58 to 96 million $\mathrm{kg}$ ( 128 to 212 million lb) $\mathrm{Sn}$ in 26.3 million tonnes (29 million tons) ore (fig. D-2).

94 Jimmy Lake-Complex Cu-Ag-Sn mineralization of late Tertiary(?) age; reported grades of up to $3,599 \mathrm{~g} /$ tonne ( $105 \mathrm{oz} /$ ton) $\mathrm{Ag}$ and $3 \% \mathrm{Cu}$ (fig. D-1).

95 Haines Barite-Major stratiform $\mathrm{Ba}-\mathrm{Pb}-\mathrm{Zn}-\mathrm{Cu}-\mathrm{Ag}$ deposit in pillow basalt-dominated section of Paleozoic or Triassic age; consists of 15 - to $18-\mathrm{m}$ - (48- to 60 -ft-) thick zone of $60 \%$ barite with upper zone [0.6 to $2.4 \mathrm{~m} \mathrm{(} 2$ to $8 \mathrm{ft}$ ) thick] of massive sulfides that contain $2 \% \mathrm{~Pb}, 3 \% \mathrm{Zn}, 1 \% \mathrm{Cu}$, up to $137 \mathrm{~g} /$ tonne ( $4 \mathrm{oz} /$ ton $) \mathrm{Ag}$, and $4 \mathrm{~g} /$ tonne $(0.12 \mathrm{oz} /$ ton $) \mathrm{Au}$. Estimated to contain 680,250 tonnes ( 750,000 tons) of $65 \%$ barite with $\mathrm{Zn}$ and $\mathrm{Ag}$ credits (fig. D-1).

96 Klukwan-Major Fe-Ti deposits in zoned ultramafic complex of Mesozoic age; reported to contain 2.7 billion tonnes ( 3 billion tons) of material that contains $16.8 \% \mathrm{Fe}$ and 1.6 to $3.0 \% \mathrm{Ti}$ (fig. D-3).

97 Nunatak-Porphyry Mo deposit; reported reserves of 7.7 million tonnes ( 8.5 million tons) ore that grades $0.125 \%$ Mo and 117 millions tonnes (129 million tons) of $0.04 \%$ Mo (fig. D-2).

98 Brady Glacier-Major $\mathrm{Ni}-\mathrm{Cu}$ deposit in layered gabbropyroxenite complex of Tertiary age. Proven reserves of 91 million tonnes (100 million tons) ore that grade $0.5 \% \mathrm{Ni}$, $0.3 \% \mathrm{Cu}$ reported and about $0.03 \% \mathrm{Co}$; also contains PGE concentrations (fig. D-3).

99 Mertie Lode and Funter Bay mining district - Contains substantial reserves of lode Au mineralization. Past production totaled about $466 \mathrm{~kg}$ ( $15,000 \mathrm{oz}) \mathrm{Au}$. Deposits also contain significant $\mathrm{Ni}-\mathrm{Cu}$ and $\mathrm{Pb}-\mathrm{Zn}-\mathrm{Ag}$ mineralization. Funter Bay deposit contains reported reserves of 507,920 tonnes ( 560,000 tons) that grade $0.34 \% \mathrm{Ni}, 0.35 \% \mathrm{Cu}$, and $0.15 \% \mathrm{Co}$ in gabbro-pipe system (fig. D-3).

100 Alaska-Juneau-Major lode Au deposit that consists of 30- to 90-m- (100- to 300-ft-) wide zone that contains en echelon, $\mathrm{Au}-$ bearing quartz veins in metamorphic rocks; produced more than $109,482 \mathrm{~kg}$ (3.52 million oz) Au from 80 million tonnes ( 88.5 million tons) ore from 1893 to 1944 . Reserves (all categories) of 96 million tonnes (105.7 million tons) of $1.7 \mathrm{~g} /$ tonne ( $0.05 \mathrm{oz} /$ ton) Au remain (fig. D-3).

101 Chichagof and Hirst Chichagof-Major lode Au deposits in quartz veins that cut Mesozoic graywacke: produced more than $23,949 \mathrm{~kg}(770,000 \mathrm{oz}) \mathrm{Au}$, most of which was produced at Chichagof Mine. Inferred leased reserves estimated to be $3,110 \mathrm{~kg}(100,000 \mathrm{oz}) \mathrm{Au}$ (fig. D-3).
Alaska Mineral Industry 1997-Special Report 52

102 Mirror Harbor-Ni-Cu mineralization in layered gabbro complex of Mesozoic age; reported proven reserves of 7,256 tonnes $(8,000$ tons $)$ of $1.57 \% \mathrm{Ni}$ and $0.88 \% \mathrm{Cu}$ and reported inferred reserves of several million tons ore that grade $0.2 \% \mathrm{Ni}$ and $0.1 \% \mathrm{Cu}$ (fig. D-3).

103 Bohemia Basin-Major Ni-Cu-Co mineralization in layered mafic complex similar to locality 102 ; reported reserves of 20 million tonnes ( 22 million tons) ore that grade 0.33 to $0.51 \%$ $\mathrm{Ni}, 0.21$ to $0.27 \% \mathrm{Cu}$, and $0.02 \% \mathrm{Co}$, all of which are recoverable with standard flotation technology (fig. D-3).

104 Apex-EI Nido-Significant lode Au-W deposits that occur as crosscutting veins in graywacke; produced more than $1,555 \mathrm{~kg}$ $(50,000 \mathrm{oz}) \mathrm{Au}($ fig. D-3).

105 Greens Creek-Major sediment-hosted $\mathrm{Pb}-\mathrm{Zn}-\mathrm{Cu}-\mathrm{Ag}-\mathrm{Au}$ volcanogenic massive sulfide deposit of Devonian or Triassic age; most recent reserve estimate of the original orebody is 10 million tonnes ( 11.0 million tons) grading $4.1 \mathrm{~g} /$ tonne $(0.12 \mathrm{oz} /$ ton) $\mathrm{Au}, 456 \mathrm{~g} /$ tonne $(13.3 \mathrm{oz} / \mathrm{ton}) \mathrm{Ag}, 12.8 \% \mathrm{Zn}$, and $4.0 \% \mathrm{~Pb}$. Additional reserves in the southwest orebody are 1.81 million tonnes ( 2.0 million tons) grading $13.5 \% \mathrm{Zn}, 5.5 \% \mathrm{~Pb}, 9.25 \mathrm{~g} /$ tonne $(0.27 \mathrm{oz} /$ ton $) \mathrm{Au}$, and $1,131 \mathrm{~g} /$ tonne $(33 \mathrm{oz} /$ ton $) \mathrm{Ag}$. Total combined reserves and resources of the mine are estimated to be 16.34 million tonnes ( 18 million tons) (fig. D-1).

106 Sumdum - Volcanogenic $\mathrm{Cu}-\mathrm{Pb}-\mathrm{Zn}$ massive sulfide deposit in Mesozoic metamorphic complex with potential strike length of over $3,048 \mathrm{~m}$ ( $10,000 \mathrm{ft})$. Inferred reserves of 24 million tonnes ( 26.7 million tons) ore that grade $0.57 \% \mathrm{Cu}, 0.37 \% \mathrm{Zn}$, and $10 \mathrm{~g} /$ tonne $(0.3 \mathrm{oz} /$ ton $) \mathrm{Ag}$ reported (fig. D-1).

107 Snettisham- $\mathrm{Fe}-\mathrm{Ti}$ deposit in mafic zoned intrusive complex; reported grades of about $18.9 \% \mathrm{Fe}$ and $2.6 \% \mathrm{Ti}$ (fig. D-3).

108 Tracy Arm - Strata-bound $\mathrm{Cu}-\mathrm{Zn}-\mathrm{Pb}$ massive sulfide prospect

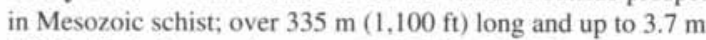
$(12 \mathrm{ft})$ thick. Reported grades of $1.5 \% \mathrm{Cu}, 3.9 \% \mathrm{Zn}, 26 \mathrm{~g} /$ tonne ( $0.76 \mathrm{oz} /$ ton) $\mathrm{Ag}$, and $0.44 \mathrm{~g} /$ tonne $(0.013 \mathrm{oz} /$ ton $) \mathrm{Au}$ (fig. D-1).

109 Red Bluff Bay-Significant chrome mineralization in Mesozoic ultramafic complex (probably ophiolite); reported reserves of 517 tonnes ( 570 tons) of material that grade $40 \% \mathrm{Cr}$ and 26,303 tonnes ( 29,000 tons) that grade 18 to $35 \% \mathrm{Cr}$ (fig. D-3).

110 Cornwallis Peninsula-Volcanogenic $\mathrm{Cu}-\mathrm{Pb}-\mathrm{Zn}-\mathrm{Ag}-\mathrm{Ba}$ massive sulfide deposit of Triassic(?) age; reported grades of up to $20 \% \mathrm{~Pb}-\mathrm{Zn}$ and $788 \mathrm{~g} /$ tonne ( $23 \mathrm{oz} /$ ton) $\mathrm{Ag}$ (fig. D-1).

111 Castle Island-Stratiform barite deposit of Triassic age hosted in carbonate and pillow basalt; about 776,390 tonnes (856,000 tons) of raw and refined barite produced from 1963 to 1980; also contains $\mathrm{Zn}, \mathrm{Pb}$, and $\mathrm{Cu}$ sulfides. Reported to be mined out (fig. D-1).

112 Groundhog Basin-Area contains several massive sulfide prospects in Mesozoic schist and gneiss whose origins are now thought to be plutonic associated. Reported grades of up to $8 \% \mathrm{~Pb}, 994 \mathrm{~g} /$ tonne ( $29 \mathrm{oz} /$ ton $) \mathrm{Ag}$, and $17 \mathrm{~g} /$ tonne $(0.5 \mathrm{oz} /$ ton $)$ $\mathrm{Au}$. Sn has also been recently identified. Area also contains potential for porphyry Mo deposits (fig. D-1).

113 Snipe Bay-Ni-Cu deposit in zoned mafic-ultramafic complex; inferred reserves of 390,000 tonnes ( 430,000 tons) of $0.3 \% \mathrm{Ni}, 0.3 \% \mathrm{Cu}$, and $4.4 \mathrm{~g} /$ tonne $(0.13 \mathrm{oz} /$ ton $) \mathrm{Ag}$ reported (fig. D-3).

114 Kasaan Peninsula-Major skarn-type $\mathrm{Cu}-\mathrm{Fe}$-Au massive sulfide deposit of Jurassic age; area has produced over 12.7 million $\mathrm{kg}$ ( 28 million $\mathrm{lb}) \mathrm{Cu}$, and $1,711 \mathrm{~kg}(55,000 \mathrm{oz})$ $\mathrm{Ag}$. Reported reserves of 3.6 million tonnes ( 4 million tons) ore that grade $50 \% \mathrm{Fe}$ and less than $2 \% \mathrm{Cu}$ (fig. D-1). 
115 Salt Chuck-Cu-PGM-Ag-Au deposit in contact zone between pyroxenite and gabbro within Alaskan-type zoned mafic-ultramafic pluton. From 1900 to $1941,2.3$ million $\mathrm{kg}$ (5 million lb) Cu, over $622 \mathrm{~kg}(20,000 \mathrm{oz})$ PGM, and Au and Ag credits were produced from 294,775 tonnes $(325,000$ tons) ore (fig. D-3).

116 Union Bay-Significant Fe-Ti mineralization in ultra-mafic complex; area also contains $\mathrm{Pt}$ and $\mathrm{V}$ concentrations (fig. D-3).

117 Hyder mining district-Area produced more than 22,675 tonnes (25,000 tons) high-grade $\mathrm{W}-\mathrm{Cu}-\mathrm{Pb}-\mathrm{Zn}-\mathrm{Ag}$ ore from 1925 to 1951 from crosscutting ore shoots in Texas Creek granodiorite of Tertiary age. Area also contains potential for porphyry Mo-W mineralization and massive sulfide-skarn $\mathrm{Pb}$ $\mathrm{Ag}-\mathrm{Au}-\mathrm{W}$ deposits (figs. D-1 and D-2).

118 Jumbo- $\mathrm{Cu}-\mathrm{Fe}-\mathrm{Mo}-\mathrm{Ag}$ skarn deposit; produced more than 4.5 million $\mathrm{kg}$ ( 10 million $\mathrm{lb}) \mathrm{Cu}, 8,708 \mathrm{~kg}(280,000 \mathrm{oz}) \mathrm{Ag}$, and $218 \mathrm{~kg}(7,000 \mathrm{oz}) \mathrm{Au}$ from 113,375 tonnes (125,000 tons) ore. Zoned magnetite-Cu skarns are associated with epizonal granodiorite pluton of Cretaceous age. Reported reserves of 589,550 tonnes $(650,000$ tons $)$ ore that grade $45.2 \% \mathrm{Fe}$, $0.75 \% \mathrm{Cu}, 0.3 \mathrm{~g} /$ tonne $(0.01 \mathrm{oz} /$ ton $) \mathrm{Au}$, and $2.74 \mathrm{~g} /$ tonne $(0.08$ oz/ton) $\mathrm{Ag}$ (fig. D-1).

119 Copper City-Stratiform $\mathrm{Cu}-\mathrm{Zn}-\mathrm{Ag}-\mathrm{Au}$ massive sulfide deposit hosted in late Precambrian or earliest Paleozoic Wales Group. Reported grades of up to $12.7 \% \mathrm{Cu}, 2.7 \% \mathrm{Zn}, 86 \mathrm{~g} /$ tonne ( $2.5 \mathrm{oz} /$ ton $) \mathrm{Ag}$, and $6.9 \mathrm{~g} /$ tonne $(0.2 \mathrm{oz} /$ ton $) \mathrm{Au}$ (fig. D-1).

120 Quartz Hill-A porphyry molybdenum deposit hosted in a 25million-year-old composite felsic pluton. Probable reserves. according to Cominco, are 210 million tonnes (232 million tons) with a grade of $0.22 \% \mathrm{MoS}_{2}$, and possible reserves are 1.1 billion tonnes ( 1.2 billion tons) with $0.12 \% \mathrm{MoS}_{2}$ (fig. D-2).

121 Niblack-Volcanogenic $\mathrm{Cu}-\mathrm{Pb}-\mathrm{Au}-\mathrm{Ag}$ massive sulfide deposit hosted in Precambrian(?) Wales Group or Ordovician to Silurian Descon Formation; produced more than $635,000 \mathrm{~kg}$ (1.4 million lb) $\mathrm{Cu}, 342 \mathrm{~kg}(11,000 \mathrm{oz}) \mathrm{Au}$, and $467 \mathrm{~kg}$ $(15,000 \mathrm{oz}) \mathrm{Ag}$. Current resource is 2.78 million tons at $3.3 \%$ $\mathrm{Zn}, 1.7 \%$ copper, $1.14 \mathrm{oz} /$ ton silver and $0.087 \mathrm{oz} /$ ton gold. The deposit is open to expansion (fig. D-1).

122 Bokan Mountain-Numerous U-Th prospects associated with Jurassic peralkaline intrusive complex; from 1955 to 1971 . produced more than 108,840 tonnes ( 120,000 tons) ore that graded about $1 \% \mathrm{U}_{3} \mathrm{O}_{8}$. Contains inferred reserves of about 36.2 million tonnes ( 40 million tons) of $0.126 \% \mathrm{Nb}$ and up to $1 \%$ REE metals (fig. D-3).

123 Kemuk Mountain-Magmatic Fe-Ti deposit hosted in Cretaceous(?) pyroxenite. Inferred reserves of 2.17 billion tonnes ( 2.4 billion tons) that average 15 to $17 \% \mathrm{Fe}, 2$ to $3 \% \mathrm{TiO}_{2}$, and $0.16 \% \mathrm{P}_{2} \mathrm{O}_{5}$ (fig. D-3).

124 McLeod-Porphyry Mo deposit that contains quartzmolybdenite fissure veins in quartz-feldspar porphyry. Chip samples contain up to $0.09 \%$ Mo (fig. D-2).

125 Johnson River-Epigenetic(?) quartz-sulfide stockwork or massive sulfide deposit hosted in volcaniclastic, pyroclastic, and volcanic rocks of Jurassic Talkeetna Formation. Deposit has drilled-out reserves at a \$50/tonne cutoff with no cut of high $\mathrm{Au}$ assays, 997,542 tonnes ( $1,099,580$ tons) grading $10.35 \mathrm{~g} /$ tonne (0.32 oz/ton) Au, $7.84 \mathrm{~g} /$ tonne $(0.24 \mathrm{oz} /$ ton $) \mathrm{Ag}, 0.76 \% \mathrm{Cu}$, $1.17 \mathrm{~Pb}$, and $8.37 \% \mathrm{Zn}$ (fig. D-3).

126 Nimiuktuk River-Small hill of massive, high-grade barite estimated to contain at least 1.36 million tonnes ( 1.5 million tons) barite. Widespread stream-sediment $\mathrm{Ba}$ anomalies in area indicate further barite potential (fig. D-1).

127 Kensington-Stockworks of quartz veins in sheared and chloritized quartz diorite produced 9,886 tonnes ( 10,900 tons) grading $6 \mathrm{~g} /$ tonne $(0.18 \mathrm{oz} /$ ton $)$ Au prior to 1930 . Recent reserve estimates indicate at least 10.4 million tonnes (11.5 million tons) grading $4.9 \mathrm{~g} /$ tonne $(0.143 \mathrm{oz} /$ ton $) \mathrm{Au}$. Subparallel Horrible vein system contains 3.56 million tonnes ( 3.93 million tons) grading $3.7 \mathrm{~g} /$ tonne $(0.11 \mathrm{oz} /$ ton $) \mathrm{Au}$ (fig. D-3).

128 Jualin-Five quartz-fissure veins in Cretaceous quartz diorite, more than $4,573 \mathrm{~m}(15,000 \mathrm{ft})$ of underground workings; produced $1,505 \mathrm{~kg}(48,387 \mathrm{oz})$ Au, mainly prior to 1930 . Reserves estimated at 0.97 million tonnes ( 1.07 million tons) of $12 \mathrm{~g} /$ tonne ( $0.349 \mathrm{oz} /$ ton) Au (fig. D-3).

129 Pebble Copper- $\mathrm{Cu}$-Au porphyry with identified resource of 1 billion tons grading $0.30 \% \mathrm{Cu}$ and $0.35 \mathrm{~g} /$ tonne $(0.010 \mathrm{oz} /$ ton $)$ Au with $\mathrm{Mo}$ in the 0.03 to $0.04 \%$ range (fig. D-1).

130 Pogo- Gold is in veins in two flat-lying $24-\mathrm{ft}$-thick "quartzites," discordant to the prevailing foliation in biotite gneiss near a felsic intrusive. Current resources are 4.5 million oz of gold in 11 million tons of rock, grading $0.41 \mathrm{oz} /$ ton (fig. D-3). 


\section{APPENDIX E \\ State and federal agencies and private interest groups involved in mineral development activities, 1997}

(Note: The 1997 Service Directory of the Alaska Miners Association lists technical and professional consultants and companies available for work in Alaska. The report is available for \$15 from the Association's Anchorage office.)

\section{STATE OF ALASKA AGENCIES \\ DEPARTMENT OF COMMERCE AND ECONOMIC DEVELOPMENT \\ State Office Building, 9th Fl. \\ P.O. Box 110800 (mailing) \\ Juneau, AK $99811-0800$ \\ (907) $465-2500$ \\ (907) 465-3767 (fax)}

\section{Function: Promotes economic} development in Alaska.

Division of Trade and Development 3601 C St., Ste, 700

Anchorage, AK 99503-5934

(907) 269-8110

(907) 269-8125 (fax)

State Office Building, 9 th Fl.

P.O. Box 110804 (mailing)

Juneau, AK 99811-0804

(907) 465-2017

751 Old Richardson Hwy., Ste. 205

Fairbanks, AK 99701

(907) 451-3050

(907) 451-3053 (fax)

Function: Primary state government advocacy agency for economic growth. Researches and publishes economic data on Alaska's mining industry. Attracts capital investment by advertising Alaska's resource potential. Provides research staff aid for the Alaska

Minerals Commission. The Division also encourages the development of new markets for Alaska resources, increases the visibility of Alaska and its products in the international marketplace, and makes referrals and provides technical assistance to those interested in developing export markets for Alaskaproduced or value-added goods and services.

\section{DEPARTMENT OF ENVIRON-}

\section{MENTAL CONSERVATION}

410 Willoughby Ave., Ste. 105

Juneau, AK 99801-1795

(907) 465-5010

(907) 465-5065 Commissioner's Office

(907) 465-5060 Public Information

(907) 465-5040 TTY

(907) 465-5097 (fax)

Function: Issues permits for activities (including mining) that affect air or water quality or involve land disposal of wastes. Sets air-and water-quality standards. Inspects, monitors, and enforces environmental quality statutes, regulations, and permits. Reviews all federal permits.

Alaska Dept. of Environmental Conservation

Anchorage Office

555 Cordova St.

Anchorage, AK 99501-2617

(907) 269-7500

(907) 269-75II TYY

Permits/Compliance Assistance

1-800-510-2332 (inside Alaska only)

1-800-269-7586 (outside Alaska)

(907) 269-7652(fax)

e-mail: compass@envircon.state.ak.us

Alaska Dept. of Environmental

Conservation

Fairbanks Office

610 University Ave.

Fairbanks, AK 99709-3643

(907) $451-2360$

(907) 451-2184 TTY

(907) 451-2188 (fax)

\section{DEPARTMENT OF FISH AND GAME}

1255 W. 8 th St.

P.O. Box 25526 (mailing)

Juneau, AK 99802-5526

(907) $465-4100$

Habitat and Restoration Division (907) 465-4105

Function: Protects habitat in fishbearing fresh waters and manages refuges, sanctuaries, and critical habitats. Requires permits for any work involving: the blockage of fish passage; equipment crossings or operation in fresh waters used by anadromous fish; use, diversion, or pollution of streams containing anadromous fish; construction, exploration, or development work in state game refuges, game sanctuaries, and critical habitat areas.

Northern Regional Office

Habitat and Restoration Division

1300 College Rd.

Fairbanks, AK 99701-1599

(907) 459-7289

Southcentral Regional Office

Habitat and Restoration Division

333 Raspberry Rd.

Anchorage, AK 99518-1599

(907) 267-2285
Southeastern Regional Office

Habitat and Restoration Division 802 3rd St., 2nd Fl.

P.O. Box 240020 (mailing)

Douglas, AK 99824-0020

(907) $465-4290$

\section{OFFICE OF MANAGEMENT}

AND BUDGET

Division of Governmental

Coordination

240 Main St., Ste. 500

P.O. Box 110030 (mailing)

Juneau, AK 99811-0030

(907) $465-3562$

Function: Conducts coordinated State review of permits for mining projects within Alaska's Coastal Management Zone. Provides project design information to applicants for consistency with the policies and standards of the Alaska Coastal Management Program. Coordinates State response to direct federal actions, including proposed regulations, that affect Alaska's mining industry.

Southcentral Regional Office Frontier Bldg. 3601 C St., Ste. 370

Anchorage, AK 99503-5930

(907) 561-6131

(907) 561-6134 (fax)

\section{DEPARTMENT OF NATURAL}

\section{RESOURCES}

400 Willoughby Ave., 5th Fl.

Juneau, AK 99801-1724

(907) 465-2400

http://www.dnr.state.ak.us

\section{Division of Forestry}

Frontier BIdg.

3601 C St., Ste. 1034

Anchorage, AK 99503-5937

(907) 269-8463

Function: Establishes guidelines to manage mining in state forests.

Interior Regional Office

3700 Airport Way

Fairbanks, AK 99709-4699

(907) 451-2660

Coastal Regional Office 400 Willoughby Ave., 3rd Fl.

Juneau, AK 99801-1724 (907) 465-2491 
Division of Geological \&

Geophysical Surveys

794 University Ave., Ste. 200

Fairbanks, AK 99709-3645

(907) 451-5000

(907) 451-5050 (fax)

e-mail: dggs@dnr.state.ak.us

http://wwwdggs.dnr.state.ak.us

Function: Conducts geological and geophysical surveys to determine: the potential of Alaska land for production of metals, minerals, fuels, and geothermal resources: locations and supplies of construction materials; potential geologic hazards to buildings, roads, bridges, and other installations and structures; and other surveys and investigations as will advance knowledge of the geology of Alaska and general geologic inventories. Publishes a variety of reports that contain the results of these investigations. Advises the public and government agencies on geologic issues. Maintains a library of geologic bulletins, reports, and periodicals. Maintains a drill-core storage facility at Eagle River.

Geologic Materials Center

P.O. Box 772805

Eagle River, AK 99577-2805

(907) 696-0079

(907) 696-0078 (fax)

Division of Land

3601 C St., Ste. 1122, Frontier Bldg.

Anchorage, AK 99503-5947

(907) 269-8503

(907) 269-8904 (fax)

Function: Manages surface estate and resources, including materials (gravel, sand, and rock). Handles statewide and regional land-use planning. Issues leases, material-sale contracts, mill-site leases, land-use permits, and easements for temporary use of State land and access roads.

Northern Regional Office

3700 Airport Way

Fairbanks. AK 99709-4699

(907) $451-2700$

(907) $451-2751$ (fax)

Southcentral Regional Office

3601 C St., Ste. 1080, Frontier Bldg.

Anchorage, AK 99503-5937

(907) 269-8552

(907) 269-8913 (fax)

Southeastern Regional Office 400 Willoughby Ave., 4th Fl.

Juneau, AK 99801-1724

(907) 465-3400

(907) 586-2954 (fax)
Division of Mining \& Water Management

Frontier Bldg.

3601 C St., Ste. 800

Anchorage, AK 99503-5935

(907) 269-8600

http://www.dnr.state.ak.us/mine_wat/

\section{A. Mining}

Function: Principal agency for management of mining and reclamation on state land in Alaska. Maintains a mining office in Fairbanks. Issues property rights to leasable minerals: adjudicates locatable mineral filings. Issues permits for hard-rock and placermining activity. Maintains records of mineral locations, permits, and leases. Provides technical, legal, and landstatus information. Administers the Alaska Surface Mining Control and Reclamation Act (ASMACRA), which includes permitting and inspection of coal mining activity and reclamation of abandoned mines.

\section{B. Water Management}

Function: Manages water resources of the state; issues water-appropriation permits and certificates; responsible for safety of all dams in Alaska; conducts surveys to determine the locations. quantity, and quality of ground and surface water.

Northern Regional Office

3700 Airport Way

Fairbanks, AK 99709-4699

(907) 451-2790 (Mining)

(907) 451-2772 (Water)

Southeastern Regional Office

400 Willoughby, 4 th Fl.

Juneau, AK 99801

(907) 465-3400

\section{Division of Parks and Outdoor Recre- ation \\ 3601 C St.. Ste. 1200 \\ Frontier Bldg. \\ Anchorage, AK 99503-5921 \\ (907) 269-8700}

Function: Manages approximately 3,000,000 acres of state park lands primarily for recreational uses, preservation of scenic values, and watershed. Responsible for overseeing mining access, recreational mining activity, and valid mining-claim holdings within state park lands. The Office of History and Archaelogy reviews mining permit applications on all lands within the state for impacts to historic resources.
Northern Regional Office

3700 Airport Way

Fairbanks, AK 99709-4699

(907) 451-2695

Southeastern Regional Office 400 Willoughby Ave., 4th Fl. Juneau, AK 99801-1724

(907) $465-4563$

Office of History and Archaeology

Frontier Bldg.

3601 C St., Ste. 1278

Anchorage, AK 99503-5921

(907) 269-8721

e-mail: michelej@dnr.state.ak.us

DEPARTMENT OF PUBLIC SAFETY 450 Whittier St.

P.O. Box 111200 (mailing)

Juneau, AK 99811-1200

(907) $465-4322$

Division of Fish and Wildlife Protection 5700 East Tudor Rd.

Anchorage, AK 99507-1225

(907) 269-5509

Function: Enforces state laws, in particular AS Title 16. Protects Alaska's fish and wildlife resources through enforcement of laws and regulations governing use of natural resources within Alaska. These laws are in Alaska Statutes 8, 16, 46, and Alaska Administrative Codes 5, 12, and 20.

\section{DEPARTMENT OF REVENUE}

State Office Bldg.

1 1 th Fl., Entrance A

P.O. Box 110400 (mailing)

Juneau, AK 99811-0400

(907) 465-2300

http://www.revenue.state.ak.us

\section{Income and Excise Audit}

\section{Division}

State Office BIdg.

11 th Fl., Entrance B

P.O. Box 110420 (mailing)

Juneau, AK 99811-0420

(907) $465-2320$

(907) 465-2375 (fax)

e-mail: fish_excise@revenue.state.ak.us http://www.revenue.state.ak.us/iea/

Function: Issues licenses for mining, production, and sale of minerals. Administers mining-license tax based on net income, including royalties. New mining operations - except sand and gravel mining - can apply for and receive certificates of tax exemption for the first $3^{1 / 2}$ years of operation. (Tax returns must be filed annually.) 


\section{UNIVERSITY OF ALASKA}

College of Science, Engineering, and Mathematics

Department of Geology \&

Geophysics

308 Natural Sciences Bldg.

900 Yukon Dr.

University of Alaska Fairbanks

Fairbanks, AK 99775-5780

(907) 474-7565

(907) 474-5163 (fax)

e-mail: geology@zorba.uafadm.alaska.edu http://www.uaf,edu/geology

Function: Provides undergraduate and graduate education in geology and geophysics and conducts basic and applied research in geologic sciences. Offers B.S., M.S., and Ph.D. program options in general geology, economic geology, petroleum geology, geophysics, and ice-snow-permafrost geophysics.

\section{School of Mineral Engineering}

PO Box 755960

Brooks Building - Rm. 209

University of Alaska Fairbanks

Fairbanks, AK 99775-5960

(907) 474-7366

(907) 474-6994 (fax)

e-mail: FYSME@uaf.edu

http://www.uaf.edu

Function: Provides undergraduate and graduate education programs in geological engineering, mining engineering, mineral preparation engineering, and petroleum engineering. Through research programs conducts laboratory and field studies to promote mineral and energy development.

\section{Mineral Industry Research}

Laboratory (MIRL)

School of Mineral Engineering

O'Neill Resources Bldg., Rm. 212B

University of Alaska Fairbanks

Fairbanks, AK 99775-7240

(907) 474-7135

(907) 474-5400 (fax)

Function: Conducts applied and basic research in exploration, development, and utilization of Alaska's mineral and coal resources with emphasis on coal characterization, coal utilization, coal upgrading, coal preparation, mineral beneficiation, fine gold recovery, hydrometallurgy, and environmental concerns. Publishes reports on research results and provides general information and assistance to the mineral industry.

Mining Extension Program

Duckering Bldg., Rm. 401

University of Alaska Fairbanks

Fairbanks, AK 99775-5800

(907) 474-7702

Function: Offers prospecting and introductory mineral and mining courses under an open admissions policy.

\section{Mining and Petroleum \\ Training Service \\ 155 Smiths Way, Ste. 101 \\ University of Alaska Anchorage \\ Soldotna, AK 99669 \\ (907) 262-2788}

Function: Provides direct training and assistance to mine operators, service and support companies, and governmental agencies in mine safety and health. mining extension, vocational mine training, and technical transfer. Specialized training services in hazardous materials, first aid and CPR, industrial hygiene, and professional safety education and consulting are available on demand.

\section{FEDERAL AGENCIES}

\section{U.S. DEPARTMENT OF \\ THE INTERIOR \\ Office of the Secretary \\ 1689 C St., Ste. 100 \\ Anchorage, AK 99501-5151 \\ (907) 271-5485 \\ (907) 271-4102}

Function: Coordinates the Department of the Interior's policy and stewardship with DOI bureaus for the management of over 200 million acres of public land in Alaska.

\section{Bureau of Land Management}

Alaska State Office

Division of Lands, Minerals, and Resources 222 West 7th Ave., \#13

Anchorage, AK 99513-7599

(907) 271-5477

Lands \& Minerals Group (907) 271-5049

Public Land Information Center (907) 271-5960

Anchorage Mineral Resources Team (907) 271-2454

http://www.ak.blm.gov/

Function: Surface manager of federal public lands (except national parks. wildlife refuges, national monuments, national forests, and military withdrawals). Performs a variety of land administration functions for federal lands. Responsible for many minerals functions on federal lands, including issuing leases for all federal leasable minerals including oil and gas, coal, phosphates, and oil shale. Arranges for sale of minerals other than leasable or materials, such as sand, gravel, or stone. Issues rights-of-way and special use permits. Monitors mining operations to ensure protection of surface resources. Maintains land status plats and issues patents. Records federal mining claims and annual assessment affidavits, and collects annual claim holding fees.

The Anchorage and Juneau Mineral Resources Teams conduct studies that aid environmentally sound development of a viable mineral industry in Alaska. Emphasis is on field programs that identify the type, amount, and distribution of mineral deposits in Alaska. The field information is augmented by studies of beneficiation technologies, economic feasibility, and economic and environmental effects of mineral development. Information is provided to government agencies to aid landplanning and land-use decisions, and to the private sector to identify targets of opportunity for further exploration and/ or development.

Anchorage Field Office

6881 Abbott Loop Rd.

Anchorage, AK 99507-2599

(907) 267-1246

(907) 267-1267 (fax)

Glennallen Field Office

PO Box 147

Glennallen, AK 99588

(907) 822-3217

(907) 822-3120 (fax

Juneau Mineral Information Center Juneau Mineral Resources Team

100 Savikko Rd.

Mayflower Island

Juneau, AK 99824

(907) 364-1553

(907) 364-1574 (fax)

Function: Built around the former U.S. Bureau of Mines library, the Center contains more than 20,000 geologic and minerals publications, provides a variety of on-line land status and mineral information services, and distributes many federal and state publications.

Kotzebue Field Office

PO Box 1049

Kotzebue, AK 99752-1049

(907) 442-3430

(907) 442-2720 (fax)

Nome Field Office

PO Box 925

Nome, AK 99762-0925

(907) 443-2177

(907) 443-3611 (fax)

Northern Field Office

1150 University Ave.

Fairbanks, AK 99709-3899 
(907) 474-2300

(907) 474-2251 Public Lands

Information Center

\section{U.S. Fish and Wildlife Service}

Region 7 Office

1011 East Tudor Rd.

Anchorage, AK 99503

(907) $786-3542$

Function: Administers the federal public lands in national wildlife refuges, issues special-use permits for activities on refuges, reviews permits and applications for various mining activities on all private and public lands and waters, and provides information to regulatory agencies on fish and wildlife and their habitat. Makes recommendations to regulatory agencies to mitigate adverse environmental impacts.

U.S. Fish and Wildlife Service Northern Alaska Ecological Services 101 12th Ave., Rm. 110

Box No. 19

Fairbanks, AK 99701

(907) 456-0327

(907) 456-0208 (fax)

U.S. Fish and Wildlife Service Southeast Alaska Ecological Services 3000 Vintage Blvd., Ste. 201 Juneau, AK 99801-7100

(907) $586-7240$

(907) 586- 7154 (fax)

U.S. Fish and Wildlife Service

Western Alaska Ecological Services 605 West 4th Ave., Rm. G-62

Anchorage, AK 99501

(907) 271-2888

(907) 271-2786 (fax)

\section{U.S. Geological Survey}

Geological Division

4200 University Dr.

Anchorage, AK 99508-4663

(907) $561-1181$

Function: Investigates and reports on the occurrence, quality, quantity, and environmental characteristics of mineral resources, the processes that create and modify them, models for assessing mineral endowment, and the potential impacts of mineral development. A major aspect of this research involves 1:250,000-scale geologic mapping.

Water Resources Division 4230 University Dr., Ste. 201 Anchorage, AK 99508-4664 (907) $786-7100$
U.S. Geological Survey Earth Science Information Center

National Mapping Division

4230 University Dr., Ste. 101

Anchorage, AK 99508-4664

(907) 786-7011

Function: Publishes and distributes all available topographic maps of Alaska, digital products, and aerial photography.

National Park Service

Alaska Regional Office

2525 Gambell St.

Anchorage, AK 99503-2892

(907) 257-2626

Function: Administers lands within the national park system in Alaska.

Manages oil and gas operations and pre-existing valid mining claims in parklands through plans of operation under Mining in Parks Act, National Park Service regulations, and other applicable federal and state laws and regulations.

\section{U.S. DEPARTMENT OF LABOR \\ Mine Safety and Health}

Administration

205 N. 4th St.

Coeur d'Alene, ID 83814-2877

(208) 667-6680

(208) 765-3099 (fax)

Juneau Field Station

NOTE: THIS OFFICE WILL. BE MOVING TO anchorage. Please call. the Coeur D'ALENE OFFICE FOR INFORMATION

Function: Administers health and safety standards to protect the health and safety of metal, nonmetal, and coal miners. Cooperates with the State to develop health and safery programs and develops training programs to help prevent mine accidents and occupationally caused diseases. Under agreement with the Coal Mine Safety and Health Office, the MSHA metal/nonmetal section has assumed responsibility for enforcement and training activities at coal mines in Alaska.

Mine Safety and Health Administration Coal Mine Safety and Health, District 9 P.O. Box 25367

Denver, CO 80225

(303) $231-5458$

(303) 231-5553 (fax)

Function: Administers health and safety standards according to the Code of Federal Regulations to protect the health and safety of coal miners; requires that each operator of a coal mine comply with these standards. Cooperates with the State to develop health and safety programs and develops training programs to help prevent coal or other mine accidents and occupationally caused diseases in the industry.

\section{U.S. DEPARTMENT OF AGRICULTURE}

Forest Service

Regional Office, Federal Bldg. P.O. Box 21628

Juneau, AK 99802-1628

(907) 586-7869

(907) 586-7843 (fax)

e-mail: jkat/r10@fs.fed.us http://www.fs.fed.us/

http://www.fs.fed.us/r10/

Function: With the Bureau of Land Management, provides joint administration of general mining laws on national forest system lands. Cooperates with Department of Interior agencies in the review and issuance of mineral leases. Issues permits for disposal of sand, gravel, and stone.

\section{U.S. ENVIRONMENTAI PROTECTION AGENCY \\ Region 10 Regional Office 12006 th Ave., MS OW-130 Seattle, WA 98101 (206) 553-1746}

Function: Issues National Pollutant Discharge Elimination System (NPDES) permits under the Clean Water Act to regulate effluent discharges. Implements a compliance enforcement program. Maintains regulatory and review authority over wetland and NEPA/EIS-related issues.

Alaska Operations Office 222 West 7th Ave., Ste. 19 Anchorage, AK 99513-7588 (907) $271-5083$

Alaska Operations Office 410 Willoughby Ave., Ste. 100 Juneau, AK 99801 (907) $586-7619$

\section{U.S. DEPARTMENT OF THE ARMY Corps of Engineers \\ Regulatory Branch \\ Attention: CEPOA-CO-R \\ P.O. Box 898 \\ Anchorage, AK 99506-0898 \\ (907) $753-2712$ or \\ (800) 478-2712 (in Alaska only) \\ (907) 753-2716 (fax)}

Function: Regulates structures or work in navigable waters of the U.S. and discharge of dredged or fill 
material into U.S. waters, including wetlands. Examples of regulated mining activities include construction of berms, dikes, diversions, ponds, overburden stripping, stockpiling, and reclamation activities.

\section{COOPERATIVE STATE- FEDERAL AGENCIES}

Alaska Public Lands
Information Center
250 Cushman St., Ste. 1A
Fairbanks, AK 99701
(907) 456-0527
(907) 456-0514 (fax)
(907) 456-0532 (TDD for hearing impaired)

Function: Clearinghouse for general information on outdoor recreation in Alaska. Information sources include U.S. Forest Service, U.S. Fish and Wildlife Service, U.S. Bureau of Land Management, U.S. Geological Survey, National Park Service, Alaska Departments of Natural Resources and Fish and Game, and Alaska Division of Tourism.

\section{BOARDS AND COMMISSIONS}

Alaska Minerals Commission
Irene Anderson, Chair
c/o Sitnasuak Native Corp.
PO Box 905
Nome, AK 99762
(907) 443-2632
(907) 443-3063 (fax)
email: Ianderson@ snc.org

Function: The Minerals Commission was created by the Alaska State Legislature in 1986 to make recommendations to the Governor and the Legislature on ways to mitigate constraints on the development of minerals in Alaska. The Commission has published annual reports since 1987.

\section{Citizens' Advisory Commission on Federal Areas 3700 Airport Way Fairbanks, AK 99709 (907) 451-2775}

Function: The Citizens' Advisory Commission on Federal Areas was established in 1981 by the Alaska Legislature to protect the rights of Alaskans to continue their traditional uses of federal lands throughout the state. This was done in response to Congressional enactment in December 1980 of the Alaska National Interest Lands Conservation Act (ANILCA), which placed millions of acres of federally owned lands into conservation system units with restrictive landuse and management requirements.

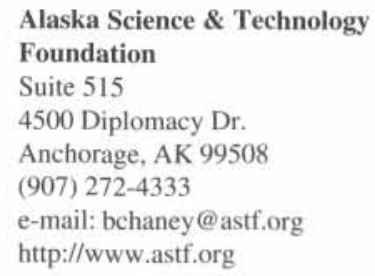

Function: The Foundation was created to make public funds available for long. term investment in economic development and technological innovation within the state and to improve the health status of its residents. Through the awarding of grants for basic and applied research and development, the Foundation will enhance the state's economy and help build its science and engineering capabilities.

\section{CHAMBERS OF COMMERCE}

Alaska State Chamber of Commerce Suite 201

217 Second St.

Juneau, AK 99801

(907) 586-2323

(907) 463-5515 (fax)

Function: The State Chamber of Commerce researches and formulates positions on Alaskan resource development. Recommendations for consideration are submitted to the State Chamber of Commerce board of directors.

Juneau Chamber of Commerce 8800 Glacier Hwy., Suite 112 Juneau, AK 99801

(907) 790-4602

e-mail: jchcomm@ptialaska.net http://www.ptialaska.net/ juneaucc

\section{Greater Fairbanks Chamber of} Commerce

250 Cushman St., Ste. 2D

Fairbanks, AK 99701-4665

(907) 452-1105

(907) 456-6968

e-mail: cocstaff@mosquitonet.com http://www.fairbankschamber.org

Anchorage Chamber of Commerce 441 West 5th Ave., Ste. 300 Anchorage, AK 99501 (907) 272-2401 e-mail: info@anchoragechamber.org http://www.anchoragechamber.org

\section{PUBLIC INTEREST GROUPS AND ASSOCIATIONS}

\author{
Alaska Clean Water Alliance \\ P.O. Box 1441 \\ Haines, AK 99827 \\ (907) 766-2296 \\ (907) 766-2290 (fax)
}

Alaska Miners Association Inc.

Statewide Office

3305 Arctic Blvd., Suite 202

Anchorage, AK 99503

(907) 563-9229

(907) 563-9225 (fax)

Denali Branch of AMA

P.O. Box 1000

Healy, AK 99743

(907) 683-2226, ext. 719

Fairbanks Branch of AMA

P.O. Box 73069

Fairbanks, AK 99707

(888) 474-2081

Juneau Branch of AMA

P.O. Box 21684

Juneau, AK 99802-1684

(907) 586-4704

(907) 463-5712

Kenai Branch of AMA

P.O. Box 242

Sterling, AK 99672

(907) 262-6383

Nome Branch of AMA

P.O. Box 1974

Nome, AK 99762

(907) 443-2632

Alaska Women in Mining

Fairbanks Branch

P.O. Box 83542

Fairbanks, AK 99708

(907) 479-9750

Juneau Branch

P.O. Box 34044

Juneau, AK 99804

(907)586-4161

Anchorage Branch

P.O. Box 240334

Anchorage, AK 99524

(907) 276-6762

Alaskans for Juneau

P.O. Box 22428

Juneau, AK 99802-2428

(907) 463-5065

American Institute of

Professional Geologists

7828 Vance Dr., Ste. 103 
Arvada, CO 80003

(303) 431-0831

(303) 431-1332 (fax)

e-mail: aipg@aipg.com

Alaska Section

2250 Woodworth Circle

Anchorage, AK 99517

(907) 258-9059

National Wildlife Federation

750 W. Second Ave., Ste. 200

Anchorage. AK 99501

(907) 258-4800

(907) 258-4811 (fax)

Northern Alaska Environmental Center

218 Driveway St.

Fairbanks, AK 99701-2895

(907) $452-5021$

(907) $452-3100$

e-mail: naec@mosquitonet.com

Northwest Mining Association

10 North Post St., Ste. 414

Spokane, WA 99201

(509) 624-1158

(509) 623-1241 (fax)

e-mail: nwma@nwma.org

http://www.nwma.org

Placer Miners of Alaska

P.O. Box 81110

Fairbanks, AK 99708

(907) 479-3100

Resource Development

Council for Alaska, Inc.

121 W. Fireweed Ln., Ste. 250

Anchorage, AK 99503

(907) 276-0700

(907) 276-3887 (fax)

e-mail: Resources@ akrdc.org

Sierra Club Legal Defense Fund

325 Fourth St.

Juneau, AK 99801

(907) 586-2751

(907) 463-5891 (fax)

e-mail: SCLDFAK@IGC.APC.ORG

Sierra Club Legal Defense Fund

11 East Main St., Ste. C

Bozeman, MT 59715

(406) $586-9699$

(406) $586-9695$ (fax)

Society for Mining, Metallurgy, and

Exploration Inc.

P.O. Box 625002

Littleton, CO 80162-5002

(303) $973-9550$

(303) $973-3845$ (fax)

Secretary Treasurer-John Rishel

1505 Atkinson Dr.

Anchorage, AK 99504

(907) 337-0511
Southeast Alaska Conservation Council

(SEACC)

419 6th St., Ste. 328

Juneau, AK 99801

(907) 586-6942

(907) 463-3312 (fax)

e-mail: info@seacc.org

http://www.juneau.com/seacc/

Trustees for Alaska

725 Christensen Dr., Ste. 4

Anchorage, AK 99501

(907) 276-4244

e-mail: ecolaw@trustees.org

\section{ORGANIZED MINING DISTRICTS}

Circle Mining District

P.O. Box 80674

Fairbanks, AK 99708

(907) 488-6058

Fairbanks Mining District

105 Dunbar

Fairbanks, AK 99701

(907) 456-7642

Fortymile Miners Association

P.O. Box 3885

Palmer, AK 99645

(907) 746-4404

Haines Mining District

P.O. Box 149

Haines, AK 99827

(907) $766-2228$

Iditarod Mining District

John A. Miscovich

General Delivery

Flat, AK 99584

Juneau Mining District

P.O. Box 20765

Juneau, AK 99802

(907) 789-4065

Kantishna Mining District

P.O. Box 84608

Fairbanks, AK 99708

Koyukuk Mining District

P.O. Box 9066

Coldfoot, AK 99701

Livengood-Tolovana Mining District

P.O. Box 55698

North Pole, AK 99705

(907) 488-6453

Valdez Creek Mining District

P.O. Box 875534

Wasilla, AK 99687-5534

Yentna Mining District

13004 NE 9th Ave.

Vancouver, WA 98685
MINERAL EDUCATION PROGRAMS

ALASKA MINERAL AND ENERGY
RESOURCE EDUCATION FUND
(AMEREF)
c/o RDC
121 W. Fireweed Ln., Ste. 250
Anchorage, AK 99503
(907) $276-0070$
(907) $276-3887$ (fax)

Function: A nonprofit corporation formed to help prepare students in grades $K-12$ to make informed decisions about Alaska's mineral and energy resources.

Alaska Department of Education 801 W. 10th St., Ste. 200

Juneau, AK 99801-1894

(907) 465-2826

\section{NATIVE REGIONAL CORPORATIONS}

\author{
AHTNA INCORPORATED \\ Main Office \\ P.O. Box 649 \\ Glennallen, AK 99588-0649 \\ (907) $822-3476$ \\ (907) 822-3495 (fax) \\ Anchorage Office \\ 406 Fireweed Ln., Ste. 204 \\ Anchorage, AK 99503-2649 \\ (907) 274-7662 \\ (907) 274-6614 (fax)
}

THE ALEUT CORPORATION

4000 Old Seward Hwy., Ste. 300

Anchorage, AK 99503-6087

(907) $561-4300$

(907) 563-4328 (fax)

\section{CORPORATION \\ P.O. Box 129 \\ Barrow, AK 99723-0129 \\ (907) $852-8633$ \\ (907) 852-5733 (fax)}

ARCTIC SLOPE REGIONAL

Anchorage Office

301 Arctic Slope Ave., Ste. 300

Anchorage, AK 99518-3035

(907) $349-2369$

(907) $349-5476$ (fax)

BERING STRAITS NATIVE CORP.

P.O. Box 1008

Nome, AK 99762-1008

(907) 443-5252

(907) 443-2985 (fax)

e-mail: bsncland@nome.net

BRISTOL BAY NATIVE CORP.

800 Cordova St.

P.O. Box 100220 (mailing) 
Anchorage, AK 99510-0220

(907) 278-3602

(907) 276-3924 (fax)

\section{CALISTA CORP}

601 W. 5th Ave., Ste. 200

Anchorage, AK 99501-2226

(907) 279-5516

(907) 272-5060 (fax)

\section{CHUGACH ALASKA CORP.}

560 E. 34th Ave., Ste. 200

Anchorage, AK 99503-4196

(907) 563-8866

(907) 563-8402 (fax)
COOK INLET REGION INC.

and its subsidary North Pacific

Mining Corporation

P.O. Box 93330

Anchorage, AK 99509-3330

(907) 274-8638

(907) 263-5183 (fax)

DOYON LTD.

2011 st Ave., Ste. 300

Fairbanks, AK 99701

(907) 459-2000

(907) 459-2060 (fax)

KONIAG INC.

4300 B St., Ste. 407

Anchorage, AK 99503

(907) $561-2668$

(907) $562-5258$ (fax)
NANA REGIONAL CORP.

P.O. Box 49

Kotzebue, AK 99752

(907) 442-3301

(907) 442-2866 (fax)

Anchorage Office

1001 E. Benson Blvd.

Anchorage, AK 99508

(907) 265-4100

(907) 265-4123 (fax)

\section{SEALASKA CORP.}

One Sealaska Plaza, Ste. 400

Juneau, AK 99801

(907) 586-1512

(907) 586-2304 (fax) 
APPENDIX F

Primary metals production in Alaska, 1880-1997

\begin{tabular}{|c|c|c|c|c|c|c|c|c|c|c|c|c|c|c|c|c|c|c|c|c|}
\hline Year & \multicolumn{2}{|c|}{ Gold } & \multicolumn{2}{|c|}{ Silver } & \multicolumn{2}{|c|}{$\begin{array}{l}\text { Mercury } \\
\text { (flask }{ }^{\mathrm{B}} \text { (15) }\end{array}$} & \multicolumn{2}{|c|}{ Antimony } & \multicolumn{2}{|c|}{ Tin } & \multicolumn{2}{|c|}{ Lead } & \multicolumn{2}{|c|}{ Zine } & \multicolumn{2}{|c|}{ Platinum } & \multicolumn{2}{|c|}{ Copper } & \multicolumn{2}{|c|}{ Chromium } \\
\hline $\begin{array}{l}1880- \\
1899\end{array}$ & $1,153,889$ & 23.85 & 496.101 & 329.0 & .. & $\cdots$ & .. & . & .. & .. & 250 & 17,0 & *. & .. & .. & -. & .. & $\cdots$ & *. & .. \\
\hline 1900 & 395,030 & 8.17 & 73,300 & 45.5 & .. & -. & -. & $\cdots$ & .. & $\because$ & 40 & 3.4 & .. & .. & -. & .. & & $\ldots$ & .. & .. \\
\hline 1901 & 335,369 & 6.93 & 47,900 & 28.6 & $\cdots$ & -. & $\cdots$ & -. & & $\ddot{8.0}$ & 40 & 3.4 & .. & -. & $\because$ & .. & 250,000 & 0.04 & .. & $\cdots$ \\
\hline 1902 & $\begin{array}{l}400,709 \\
420,069\end{array}$ & $\begin{array}{l}8.28 \\
8.68\end{array}$ & $\begin{array}{r}92,000 \\
143,600\end{array}$ & $\begin{array}{r}48.5 \\
77.8\end{array}$ & $\cdots$ & .. & & $\because$ & $\begin{array}{l}30,000 \\
50,000\end{array}$ & $\begin{array}{r}8.0 \\
14.0\end{array}$ & 30 & 2.5 & $\cdots$ & $\cdots$ & - & .. & 360,000 & 0.04 & $\cdots$ & $\cdots$ \\
\hline $\begin{array}{l}1903 \\
1904\end{array}$ & $\begin{array}{l}420,069 \\
443,115\end{array}$ & $\begin{array}{l}8.68 \\
9.16\end{array}$ & $\begin{array}{l}143,600 \\
198,700\end{array}$ & $\begin{array}{r}77.8 \\
114.9\end{array}$ & $\cdots$ & .. & $\cdots$ & $\cdots$ & $\begin{array}{l}50,000 \\
28,000\end{array}$ & & 30 & 2.5 & $\cdots$ & .. & - & $\cdots$ & $1,200,000$ & 0.16 & -. & $\cdots$ \\
\hline $\begin{array}{l}1904 \\
1905\end{array}$ & $\begin{array}{l}443.115 \\
756.101\end{array}$ & $\begin{array}{r}9.16 \\
15.63\end{array}$ & $\begin{array}{l}198,700 \\
132 \\
1374\end{array}$ & 114.9 & .. & -. & & -. & & 8.0 & 30 & 2.5 & .. & & -. & .. & $2,043,586$ & 0.28 & .. & $\cdots$ \\
\hline $\begin{array}{l}1905 \\
1906\end{array}$ & $\begin{array}{r}756,101 \\
+, 066,030\end{array}$ & $\begin{array}{l}15.63 \\
22.04\end{array}$ & $\begin{array}{l}132,174 \\
203,500\end{array}$ & 80.2 & $\cdots$ & .. & $\cdots$ & $\cdots$ & 12,000 & 4.0 & 30 & 2.6 & .. & .. & -. & .. & $4,805,236$ & 0.75 & .. & .. \\
\hline $\begin{array}{l}1906 \\
1907\end{array}$ & $\begin{array}{r}1,066,030 \\
936,043\end{array}$ & $\begin{array}{l}22.04 \\
19.35\end{array}$ & $\begin{array}{l}203,500 \\
149,784\end{array}$ & 136.4 & $\cdots$ & -. & .. & .. & 68,000 & 38.6 & 30 & 3.4 & .. & -. & -. & .. & $5,871,811$ & 1.13 & .. & .. \\
\hline $\begin{array}{l}1907 \\
1908\end{array}$ & $\begin{array}{l}936,043 \\
933,290\end{array}$ & $\begin{array}{l}19.35 \\
19.29\end{array}$ & $\begin{array}{l}149,784 \\
135,672\end{array}$ & 98.8 & .. & -. & .. & $\cdots$ & 44,000 & 16.8 & 30 & 3.2 & .. & $\cdots$ & -. & .. & $6,308,786$ & 1.26 & .. & $\cdots$ \\
\hline $\begin{array}{l}1908 \\
1909\end{array}$ & $\begin{array}{l}933,290 \\
987,417\end{array}$ & $\begin{array}{l}19.29 \\
20.41\end{array}$ & $\begin{array}{l}135,672 \\
147,950\end{array}$ & 71.9 & $\because$ & $\cdots$ & $\cdots$ & $\because$ & 50,000 & 15.2 & 40 & 3.4 & -. & .. & -. & $\cdots$ & $4,385,362$ & 0.61 & -. & .. \\
\hline $\begin{array}{l}1909 \\
1910\end{array}$ & $\begin{array}{l}987,417 \\
780,131\end{array}$ & 16.13 & $\begin{array}{l}147,950 \\
157,850\end{array}$ & $\begin{array}{l}76.9 \\
85.2\end{array}$ & $\ldots$ & $\ldots$ & $\cdots$ & $\cdots$ & $\begin{array}{l}22,000 \\
20,000\end{array}$ & 76 & 69 & 5.9 & .. & .. & .. & $\ldots$ & $4,124,705$ & 0.54 & .. & .. \\
\hline 1911 & 815,276 & 16.85 & $\begin{array}{l}157,850 \\
460,231\end{array}$ & $\begin{array}{r}85.2 \\
243.9\end{array}$ & .. & .. & $\ldots$ & $\ldots$ & $\begin{array}{r}20,000 \\
122,000\end{array}$ & 8.3 & 75 & 6.6 & .. & $\cdots$ & .. & $\cdots$ & $4,241,689$ & 0.54 & $\cdots$ & .. \\
\hline 1912 & 829,436 & 17.14 & 515,186 & $\begin{array}{l}243.9 \\
316.8\end{array}$ & .. & .. & $\ldots$ & $\ldots$ & $\begin{array}{l}122,000 \\
260,000\end{array}$ & $\begin{array}{r}52.8 \\
1196\end{array}$ & 51 & 4.5 & $*$ & $\cdots$ & $\ddot{*}$ & $\because$ & $\begin{array}{l}27,267,778 \\
20730\end{array}$ & 3.40 & 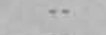 & . \\
\hline 1913 & 755947 & 15.63 & 362,563 & 218.9 & .. & .. & .. & $\ldots$ & & $\begin{array}{l}119.6 \\
44.1^{\mathrm{c}}\end{array}$ & $\begin{array}{r}45 \\
6\end{array}$ & $\begin{array}{l}4.1 \\
0.6\end{array}$ & $\ddot{*}$ & $\cdots$ & $\because$ & $\ldots$ & $\begin{array}{l}29,230,491 \\
21,659,958\end{array}$ & 4.82 & $\cdots$ & $\ddot{x}$ \\
\hline 1914 & 762,596 & 15.76 & 394,805 & 218.3 & .. & .. & .. & .. & 208,000 & 66.6 & 28 & 1.3 & .. & .. & .. & .. & $\begin{array}{l}21,659,958 \\
21,450,628\end{array}$ & $\begin{array}{l}3,35 \\
2.85\end{array}$ & $\because$ & .. \\
\hline 1915 & 807,966 & 16.70 & $1,071,782$ & 543,3 & $\cdots$ & .. & 520,000 & w & 204,000 & 78.8 & 437 & $4 ! .1$ & $\ldots$ & * & .. & $\ldots$ & $86,309,312$ & 15.14 & .. & .. \\
\hline 1916 & 834,068 & 17.24 & $1,379,171$ & 907.4 & .. & .. & $1,200,000$ & w & 278,000 & 121.0 & 820 & 113.2 & .. & ct. & 8 & 0.7 & $119,654,839$ & 29.50 & - & .. \\
\hline 1917 & 709,049 & 14.66 & $1.239,150$ & $1,020.6$ & $\cdots$ & $\ldots$ & 500,000 & W & 200,000 & 123.3 & 852 & 146.6 & $\cdots$ & .. & 53 & 5.5 & $88,793,400$ & 24.40 & 1,100 & w \\
\hline 1918 & 458,641 & 9.48 & $\begin{array}{l}847,789 \\
600700\end{array}$ & 847.8 & .. & .. & 540,000 & w & 136,000 & 118.0 & 564 & 80.1 & .. & .. & 284 & 36.6 & $69,224,951$ & 17.10 & 1,100 & w \\
\hline 1919 & 455,984 & 9.42 & 629.708 & 705.3 & $\therefore$ & $\therefore$ & ... & .. & 112.000 & 73.4 & 687 & 72.1 & ... & .. & 569 & 73.7 & 47.220 .271 & 8.80 & .. & $\rightarrow$ \\
\hline 1920 & 404,683 & 8.37 & 953,546 & $1,039.7$ & $\ddot{z}$ & $\because$ & .. & .. & 32,000 & 16.1 & 875 & 140.0 & .. & .. & 1,478 & 160.1 & $70,435,363$ & 13.00 & .. & .. \\
\hline 1921 & 390,558 & 8.07 & 761,085 & 761.1 & 45 & 1.5 & - & .. & 8,000 & 2.4 & 759 & 68.3 & & & 40 & 2.7 & $57,011,597$ & 7,40 & -. & .. \\
\hline 1922 & 359,057 & 7.42 & 729,945 & 729.9 & $\cdots$ & ... & .. & .. & 2,800 & 0.9 & 377 & 41.5 & & .. & 29 & 2.8 & $77,967,819$ & 10.50 & -. & .. \\
\hline 1923 & 289,539 & 5.98 & 814,649 & 668.1 & .. & $\cdots$ & .. & .. & 3,800 & 1.6 & 410 & 57.4 & & -. & .. & .. & $85,920,645$ & 12.60 & .. & -. \\
\hline 1924 & 304,072 & 6.29 & 669,641 & 448,6 & 2 & 0.3 & $\cdots$ & .. & 14,000 & 7.1 & 631 & 100.9 & & $\cdots$ & 28 & 2.6 & $74,074,207$ & 9.70 & .. & .. \\
\hline 1925 & 307,679 & 6.36 & 698.259 & 482.4 & 44 & 3.6 & w & w & 28,600 & 15.4 & 789 & 140.6 & -. & .. & 10 & 1.2 & $73,055,298$ & 10.30 & .. & .. \\
\hline 1926 & 324,450 & 6.70 & 605,190 & 377.0 & 22 & 1.7 & W & w & 16,000 & 10.4 & 778 & 124.4 & .. & -. & 3,570 & 274.5 & $67,778,000$ & 9.49 & .. & .. \\
\hline 1927 & 286,720 & 5.97 & 350,430 & 215.0 & .. & .. & .. & .. & 53,400 & 34.0 & 1,008 & 127.0 & .. & .. & ‥ & -. & $55,343,000$ & 7.25 & .. & .. \\
\hline 1928 & 331.140 & 6.85 & 351,730 & 187,0 & $\because$ & 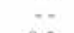 & -. & .. & 82,000 & 41.0 & 1,019 & 118.0 & .. & -. & 120 & 9.0 & $41,421,000$ & 5.96 & .. & -. \\
\hline 1929 & 375,438 & 7.76 & 472,900 & 252.0 & 4 & 0.5 & .. & .. & 77,200 & 35.0 & 1,315 & 166.0 & ... & .. & 475 & 32.0 & $40,570,000$ & 7.13 & .. & .. \\
\hline 1930 & 408,983 & 8.47 & 408,570 & 157.3 & $\ddot{z}$ & $\because$ & 0. & $*$ & 29,400 & 9.3 & 1.365 & 136.5 & $\cdots$ & $\cdots$ & $\because$ & $\cdots$ & $32,651,000$ & 4.24 & .. & $\cdots$ \\
\hline 1931 & 459,000 & 9.51 & 352,000 & 1020 & 15 & 1.2 & $\cdots$ & $\ldots$ & 8.200 & 2.0 & 1.660 & 126,0 & .. & .. & 393 & 14.0 & $22,614,000$ & 1.88 & .. & .. \\
\hline 1932 & 493,860 & 10.20 & 234,050 & 66.0 & 8 & 0.5 & $\ldots$ & .. & & $\because$ & 1,260 & 75,6 & .. & .. & $\ddot{0}$ & $\ldots$ & $8,738,500$ & 0.55 & $\ldots$ & .. \\
\hline 1933 & 469,286 & 9.70 & 154,700 & 55.0 & $\cdots$ & .. & .. & .. & 5,800 & 2.3 & 1.157 & 85.6 & $\cdots$ & $\cdots$ & 605 & 18.6 & 29,000 & 0.02 & $\cdots$ & .. \\
\hline 1934 & 537,281 & 8.78 & 154,700 & 100.0 &.+ & .. & $\cdots$ & $\cdots$ & $8,200^{c}$ & 43 & 839 & 62.1 & $\cdots$ & $\cdots$ & 2.555 & 85.6 & 121.000 & 0.06 & ... & -. \\
\hline 1935 & 469,495 & 16.43 & 286,600 & 206.0 & *. & .. & $\cdots$ & $\cdots$ & 98,800 & 49.8 & 815 & 65.2 & 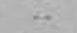 & .. & 8,685 & 259.6 & $15,056,000$ & 1.25 & .. & .. \\
\hline 1936 & 540,580 & 18.92 & 484,306 & 375.0 & .. & .. & & .. & 226,000 & 105.0 & $94 t$ & 86.6 & $\ldots$ & .. & 5.654 & 241.9 & $39.267,000$ & 3.72 & 0. & .. \\
\hline 1937 & 627,940 & 21,98 & 494,340 & 382.0 & .. & .. & 962,000 & 147.6 & $372,000^{\mathrm{C}}$ & $2023^{\mathrm{e}}$ & 823 & 97.1 & .. & .. & 9,823 & 313.4 & $36,007,000$ & 4.74 & $\ldots$ & -. \\
\hline 1938 & 662,000 & 23.17 & 479.853 & 310.0 & 8 & 0.6 & 444,000 & 54.8 & 210,000 & 89.1 & 994 & 91.5 & .. & .. & 41,000 & $2,460.0$ & $29,760,000$ & 2.98 & .. & *. \\
\hline 1939. & 676.780 & 23.68 & 201,054 & 136.5 & ... & & 210,000 & 25.9 & 66.000 & 38.0 & 937 & 88.1 & ... & .. & 33,900 & 2.034 .0 & 278.500 & 0.04 & .. & .. \\
\hline 1940 & 755,900 & 26.45 & 191,679 & 136.3 & $156^{6}$ & 130.9 & 306,000 & 42.8 & 92,000 & 52.0 & 840 & 72.0 & .. & .. & 28,886 & $1,093.0$ & 110,000 & 0.02 & .. & -. \\
\hline 1941 & 692,314 & 24.23 & 199,700 & 142.0 & w & w & 774,000 & 87.3 & $93,600^{\mathrm{c}}$ & $61.0^{c}$ & 742 & 58.0 & .. & & 22,630 & 813,0 & 144,000 & 0.02 & .. & $\cdots$ \\
\hline 1942 & $\begin{array}{r}487,657 \\
0058\end{array}$ & 17.07 & $\begin{array}{r}135,200 \\
\end{array}$ & 96.0 & W & W & 316,000 & 41.0 & $\begin{array}{r}5,600 \\
\end{array}$ & 2.5 & 523 & 44.0 & .. & .. & 22,000 & 779.0 & 48,000 & 0.01 & $\cdots$ & -. \\
\hline 1943 & 99,583 & 3.49 & 31,700 & 22,0 & 786 & 153.4 & 368,000 & 33.3 & $2,000^{\mathrm{c}}$ & $1.0^{\mathrm{c}}$ & 200 & 22.0 & .. & & 27,900 & $1,020.0$ & 54,000 & 0.01 & 5,564 & 186.3 \\
\hline 1944 & 49,296 & 1.73 & 15,240 & 10.8 & 841 & 165.0 & 70,080 & 30.0 & .. & .. & 44 & 5.8 & .. & .. & 33,616 & $2,017.0$ & 4,000 & 0.01 & 1,845 & 64.6 \\
\hline 1945 & 68,117 & 2.38 & 9,983 & 6.2 & 275 & 180.0 & w & w & .. & -. & 11 & 1.8 & .. & .. & 22,949 & $1,377.0$ & 10,000 & 0.01 & .. & .. \\
\hline 1946 & 226,781 & 7.93 & 41,793 & 26.3 & 699 & 68.7 & W & W & $\ddot{0}$ & $\because$ & 115 & 25.0 & $\ddot{0}$ & 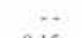 & 22,882 & $1,418.7$ & 4,000 & 0.01 & .. & .. \\
\hline 1947 & 279,988 & 9.79 & 66,150 & 46.3 & 127 & 10.6 & 52,000 & 16.1 & 2,000 & 2.2 & 255 & 76.5 & 226 & 0.15 & 13,512 & $1,351.2$ & 24,000 & 0.06 & .. & .. \\
\hline 1948 & 248,395 & 8.69 & 67,341 & 58.7 & 108 & 7.8 & 88,000 & 29.3 & 10,000 & 10.8 & 317 & 88.9 & 226 & 0.15 & 13,741 & $1,209.2$ & 28,000 & 0.07 & .. & .. \\
\hline 1949 & 229,416 & 8.03 & 36,056 & 32.4 & 102 & 7.9 & 88,000 & 31.3 & 114,000 & 100.8 & 49 & 11.2 & 226 & 0.15 & 17,169 & $1,545.2$ & 7,700 & 0.02 & $\ldots$ & $\ldots$ \\
\hline
\end{tabular}



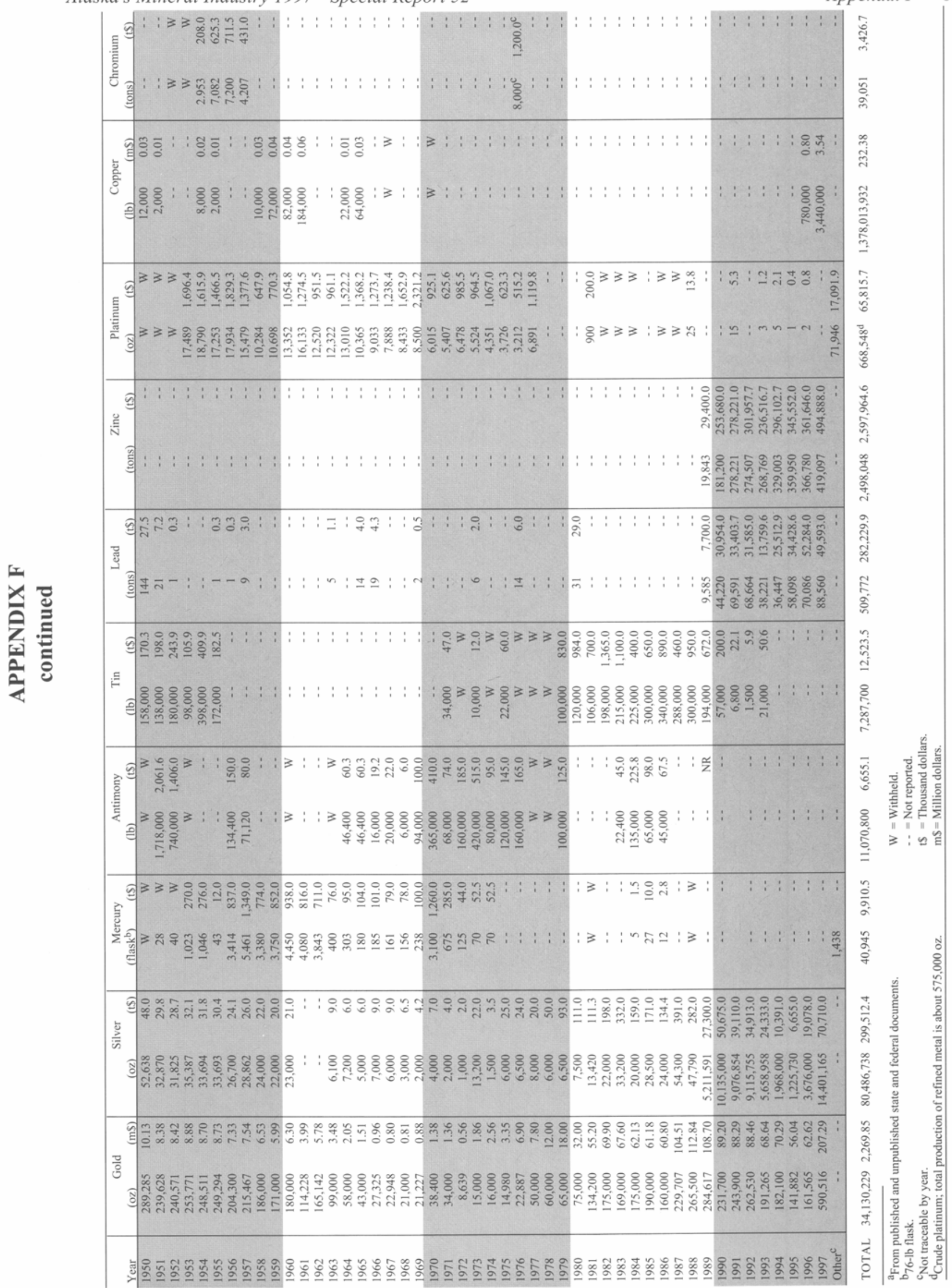
APPENDIX G

Production of industrial minerals, coal, and other commodities in Alaska, 1880-1997

\begin{tabular}{|c|c|c|c|c|c|c|c|c|c|}
\hline \multirow[b]{2}{*}{ Year } & \multicolumn{2}{|c|}{ Coal } & \multicolumn{2}{|c|}{ Sand and gravel } & \multicolumn{2}{|c|}{ Rock $^{\mathrm{a}}$} & \multicolumn{2}{|c|}{ Barite } & \multirow{2}{*}{$\begin{array}{c}\text { Other }^{b} \\
\$\end{array}$} \\
\hline & s. tons & $\mathrm{ms}$ & s. tons & & s. tons & $\mathrm{mS}$ & s. tons & t\$ & \\
\hline $1880-1899^{\circ}$ & 19.429 & 0.14 & .. & -. & 7,510 & 0.04 & -. & .. & .. \\
\hline 1900 & $1,200^{d}$ & $0.02^{\mathrm{d}}$ & $\cdots$ & $\cdots$ & 510 & 0.01 & $\cdots$ & $\cdots$ & $\cdots$ \\
\hline 1901 & $1,300^{\mathrm{d}}$ & $0.02^{\mathrm{d}}$ & -. & -. & 700 & 0.01 & -. & -. & 500 \\
\hline 1902 & $2,212^{\mathrm{d}}$ & $0.02^{\mathrm{d}}$ & - & - & 800 & 0.01 & -. & -. & 255 \\
\hline 1903 & 1,447 & 0.01 & -. & - & 920 & 0.01 & .. & .. & 389 \\
\hline 1904 & 1,694 & 0.01 & $\cdots$ & - & 1,080 & 0.02 & - & -. & 2,710 \\
\hline 1905 & 3,774 & 0.02 & - & -. & 970 & 0.02 & $\cdots$ & -. & 740 \\
\hline 1906 & 5,541 & 0.02 & $\cdots$ & $\cdots$ & 2,863 & 0.03 & .. & -. & 19,965 \\
\hline 1907 & 10,139 & 0.05 & & - & 3,899 & 0.03 & -. & .. & 54,512 \\
\hline 1908 & $3,107^{d}$ & $0.01^{\mathrm{d}}$ & $\cdots$ & $\cdots$ & 2,176 & 0.03 & -. & -. & 81,305 \\
\hline 1909 & 2,800 & 0.02 & .. & .. & 1,400 & 0.01 & .. & .. & 86,027 \\
\hline 1910 & $1,000^{d}$ & $0.01^{d}$ & $\cdots$ & $\cdots$ & W & W & $\ldots$ & $\ldots$ & 96,408 \\
\hline 1911 & $900^{d}$ & $0.01^{d}$ & . & .. & W & w & -. & $\ldots$ & 145,739 \\
\hline 1912 & $355^{\mathrm{d}}$ & $0.01^{d}$ & .. & .. & w & W & .. & $\ldots$ & 165,342 \\
\hline 1913 & 2,300 & 0.01 & .. & .. & W & W & .. & 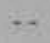 & 286,277 \\
\hline 1914 & 1,190 & 0.01 & $\ldots$ & $\therefore$ & W & W & .. & $\ldots$ & 199,767 \\
\hline 1915 & 1,400 & 0.03 & . & $\cdots$ & W & W & .. & $\ldots$ & 205.061 \\
\hline 1916 & 12,676 & 0.05 & $\ldots$ & $\cdots$ & W & w & .. & $\ldots$ & 326,731 \\
\hline 1917 & 54,275 & 0.27 & .. & $\ldots$ & W & W & .. & .. & 203,971 \\
\hline 1918 & 75,816 & 0.41 & .. & .. & w & W & .. & .. & 171,452 \\
\hline 1919 & 60.894 & 0.35 & .. & .. & 50.014 & 0.29 & $\ldots$ & $\ldots$ & 214,040 \\
\hline 1920 & 61,111 & 0.36 & $\cdots$ & $\cdots$ & 37,044 & 0.27 & .. & -. & 372,599 \\
\hline 1921 & 76,817 & 0.49 & $\cdots$ & -. & 59,229 & 0.31 & - & - & 235,438 \\
\hline 1922 & 79,275 & 0.43 & $\cdots$ & .. & 54,251 & 0.30 & $\cdots$ & - & 266,296 \\
\hline 1923 & 119,826 & 0.76 & - & -. & 83,586 & 0.41 & .. & - & 229,486 \\
\hline 1924 & 99,663 & 0.56 & - & -. & 35,294 & 0.26 & .. & - & 348,728 \\
\hline 1925 & 82,868 & 0.40 & - & -. & 32,193 & 0.19 & .. & - & 454,207 \\
\hline 1926 & 87,300 & 0.46 & $\cdots$ & .. & 33,283 & 0.20 & .. & - & 423,000 \\
\hline 1927 & 104,300 & 0.55 & $\cdots$ & - & 41,424 & 0.22 & -. & - & .. \\
\hline 1928 & 126,100 & 0.66 & . & $\cdots$ & 63,347 & 0.31 & .. & -. & . \\
\hline 1929 & 100,600 & 0.53 & . & .. & 54,766 & 0.26 & .. & .. & 194,000 \\
\hline 1930 & 120,100 & 0.63 & $\cdots$ & $\cdots$ & 66,234 & 0.33 & $\cdots$ & .. & 157,300 \\
\hline 1931 & 105,900 & 0.56 & .. & .. & 59,175 & 0.29 & $\ldots$ & .. & 108,000 \\
\hline 1932 & 102,700 & 0.53 & .. & -. & 54,167 & 0.27 & .. & .. & 223,400 \\
\hline 1933 & 96,200 & 0.48 & $\cdots$ & .. & 56,291 & 0.28 & .. & .. & .. \\
\hline 1934 & 107,500 & 0.45 & $\ldots$ & .. & 64,234 & 0.36 & .. & .. & 46,155 \\
\hline 1935 & 119.425 & 0.50 & .. & $\cdots$ & 74,049 & 0.38 & . & .. & 46,755 \\
\hline 1936 & 136,593 & 0.57 & $\ldots$ & $\cdots$ & 76,379 & 0.38 & $\ldots$ & .. & 45,807 \\
\hline 1937 & 131.600 & 0.55 & .. & .. & 50,057 & 0.25 & .. & .. & 147,048 \\
\hline 1938 & 159,230 & 0.62 & . & . & 189,090 & 0.21 & . & $\ldots$ & 125,302 \\
\hline 1939 & 143,549 & 0.60 & 42,332 & 0.02 & . & .. & .. & .. & .. \\
\hline 1940 & 170,174 & 0.88 & 515,011 & 0.10 & $\cdots$ & - & $\cdots$ & $\cdots$ & $\ldots$ \\
\hline 1941 & 241,250 & 0.97 & 530,997 & 0.09 & $\cdots$ & -. & $\cdots$ & - & $1,367,000$ \\
\hline 1942 & 246,600 & 0.99 & W & W & $\cdots$ & $\cdots$ & - & .. & $1,124,000$ \\
\hline 1943 & 289,232 & 1.84 & W & W & $\cdots$ & -. & -. & .. & . \\
\hline 1944 & 352,000 & 2.37 & 712,496 & 0.50 & $\cdots$ & - & $\cdots$ & -. & $2,350,309$ \\
\hline 1945 & 297,644 & 1.87 & W & W & $\cdots$ & $\cdots$ & -. & $\cdots$ & $5,910,704$ \\
\hline 1946 & 368,000 & 2.36 & W & w & $\cdots$ & - & - & -. & $2,005,241$ \\
\hline 1947 & 361,220 & 2.55 & W & W & 219,000 & 1.00 & -. & - & $5,927,319$ \\
\hline 1948 & 407,906 & 2.79 & W & W & 67,341 & 0.33 & .. & .. & $1,257,699$ \\
\hline 1949 & 455,000 & 3.60 & W & W & W & W & - & .. & $7,181,886$ \\
\hline 1950 & 421.455 & 3.03 & $3,050,020$ & 2.38 & W & W & $\cdots$ & .. & $2,100,000$ \\
\hline 1951 & 494,333 & 3.77 & $6,818,000$ & 3.54 & w & W & .. & .. & $3,600,000$ \\
\hline 1952 & 648,000 & 5.77 & $6,817,800$ & 3.54 & W & W & .. & .. & $9,052,000$ \\
\hline 1953 & 861,471 & 8,45 & $7,689,014$ & 5.08 & 47,086 & 0.17 & -. & .. & 1.231 .350 \\
\hline 1954 & 666,618 & 6.44 & $6,639,638$ & 6.30 & 283,734 & 0.47 & .. & . & $1,572,150$ \\
\hline 1955 & 639,696 & 5.76 & $9,739,214$ & 8.24 & 265,740 & 0.29 & - & .. & $1,552,427$ \\
\hline 1956 & 697.730 & 6.37 & $9,100,000$ & 8.30 & 50,000 & 0.02 & .. & .. & $1,551,500$ \\
\hline 1957 & 842,338 & 7.30 & $6,096,000$ & 8.79 & 528,000 & 1.95 & $\cdots$ & - & $2,751,000$ \\
\hline 1958 & 759,000 & 6.93 & $4,255,000$ & 3.87 & 615,000 & 2.07 & $\cdots$ & .. & 695,000 \\
\hline 1959 & $602.000^{d}$ & $5.88^{\mathrm{d}}$ & $5,600,000$ & 5.10 & 54.000 & 0.20 & .. & $\ldots$ & $1.338,000$ \\
\hline
\end{tabular}




\begin{tabular}{|c|c|c|c|c|c|c|c|c|c|}
\hline \multirow[b]{2}{*}{ Year } & \multicolumn{2}{|c|}{ Coal } & \multicolumn{2}{|c|}{ Sand and gravel } & \multicolumn{2}{|l|}{ Rock $^{a}$} & \multicolumn{2}{|c|}{ Barite } & \multirow{2}{*}{$\begin{array}{c}\text { Other } \\
\$\end{array}$} \\
\hline & s. tons & $\mathrm{m} \$$ & s. tons & $\mathrm{m \$}$ & s. tons & $\mathrm{ms}$ & s. tons & t\$ & \\
\hline 1960 & $669,000^{d}$ & $5.95^{\mathrm{d}}$ & $5,892,000$ & 5.35 & 80,000 & 0.30 & $\ldots$ & - & 975,000 \\
\hline 1961 & $650,000^{d}$ & $5.87^{\mathrm{d}}$ & $5,241,000$ & 4.19 & - & .. & -. & -. & $\ldots$ \\
\hline 1962 & $675,000^{d}$ & $6.41^{d}$ & $5,731,000$ & 5.36 & - & - & $\cdots$ & -. & $\ldots$ \\
\hline 1963 & 853,000 & 5.91 & $16,926,000$ & 22.01 & W & W & W & W & $2,589,000$ \\
\hline 1964 & 745,000 & 5.01 & $26,089,000$ & 18.49 & W & W & W & W & $4,912,000$ \\
\hline 1965 & $860,000^{d}$ & $5.88^{d}$ & $29,959,000$ & 33.93 & W & W & W & W & $5,296,000$ \\
\hline 1966 & 927,000 & 6.95 & $17,457,000$ & 21.79 & w & W & 44,000 & 350.0 & $6,167,000$ \\
\hline 1967 & 930,000 & 7.18 & $22,300,000$ & 26.25 & W & W & W & W & $4,924,000$ \\
\hline 1968 & $812,000^{d}$ & $5.03^{\mathrm{d}}$ & $17,515,000$ & 20.73 & W & W & 91,000 & W & $4,117,000$ \\
\hline 1969 & $728,000^{d}$ & $4.65^{d}$ & $16,205,000$ & 18.62 & $1,954,000$ & 3.90 & 90,000 & 850.0 & $5,163,000$ \\
\hline 1970 & $786,000^{d}$ & $5.28^{d}$ & $20,375,000^{d}$ & $26.07^{d}$ & $6,470,000$ & 10.01 & $134,000^{d}$ & $1,875.0$ & $7,994,000$ \\
\hline 1971 & $748.000^{d}$ & $5.05^{d}$ & $26,391,000$ & 41.99 & $2,658,000$ & 5.07 & $102,000^{d}$ & $1,075.0$ & . \\
\hline 1972 & $720,000^{d}$ & $6.26^{\mathrm{d}}$ & $14,187,000$ & 15.21 & 652,000 & 3.01 & W & W & - \\
\hline 1973 & $700,000^{d}$ & $6.23^{\mathrm{d}}$ & 19.350 .000 & 19.01 & $5,967,000$ & 12.00 & 112,000 & $1,792.0$ & $12,846,000$ \\
\hline 1974 & 700,000 & 7.34 & $118,740,000^{\mathrm{d}}$ & $240.94^{d}$ & $5,484,000$ & 12.95 & 110,000 & $1,895.0$ & $14,495,000$ \\
\hline 1975 & 766,000 & 7.81 & $48,145,000$ & 95.78 & 8.877 .000 & 26.65 & $2,000^{\mathrm{d}}$ & 30.0 & $12,731,000$ \\
\hline 1976 & 705,000 & 8.00 & $74,208,000^{d}$ & $204.73^{d}$ & $6,727,000$ & 20.09 & W & W & $14,019,000$ \\
\hline 1977 & $780,000^{d}$ & $12.00^{\mathrm{d}}$ & $66,126,000$ & 134.25 & $4,008,000$ & 17.47 & . & - & $14,486,000$ \\
\hline 1978 & 750,000 & 15.00 & $51,100,000$ & 122.00 & $3.437,000$ & 14.65 & 22,000 & 750.0 & . \\
\hline 1979 & 750,000 & 16.00 & $50,900,000$ & 104.90 & $3.650,000$ & 15.45 & 20,000 & 800.0 & 930.000 \\
\hline 1980 & 800,000 & 16.00 & $40,000,000$ & 86.00 & $3,700,000$ & 15.40 & 50,000 & $2,000.0$ & 97,500 \\
\hline 1981 & 800,000 & 17.60 & $46,000,000$ & 88.20 & $4,200,000$ & 19.30 & . & - & 256,000 \\
\hline 1982 & 830,000 & 18.00 & $45,000,000$ & 91.00 & $3,400,000$ & 15.60 & .. & $\cdots$ & 150,000 \\
\hline 1983 & 830,000 & 18.00 & $50,000,000$ & 105.00 & $5,270,000$ & 25.00 & .. & - & 242,000 \\
\hline 1984 & 849,161 & 23.75 & $27,000,000$ & 95.00 & $2,700,000$ & 16.00 & .. & -. & 875,875 \\
\hline 1985 & $1,370,000$ & 39.73 & $28,184,080$ & 112.06 & $2,500,000$ & 12.00 & .. & .. & 559,000 \\
\hline 1986 & $1,492,707$ & 40.10 & $20,873,110$ & 75.76 & $4,200,000$ & 20.32 & -. & - & 384,800 \\
\hline 1987 & $1,508,927$ & 42.35 & $16,696,374$ & 42.66 & $1,805,000$ & 11.62 & .. & $\cdots$ & 388,400 \\
\hline 1988 & $1,551,162$ & 44.30 & $17,264,500$ & 48.75 & $3,600,000$ & 24.65 & .. & $\cdots$ & 389,000 \\
\hline 1989 & $1,452,353$ & 41.46 & $14,418,000$ & 39.88 & $2,914,000$ & 20.34 & .. & $\ldots$ & $1,492,000$ \\
\hline 1990 & $1,576,000$ & 44.99 & $15,013,500$ & 40.82 & $3,200,000$ & 22.10 & $\cdots$ & $\ldots$ & 400,000 \\
\hline 1991 & $1.540,000$ & 39.00 & $14,160,011$ & 45.45 & $3,000,000$ & 22.50 & .. & $\cdots$ & 462,000 \\
\hline 1992 & $1,531,800$ & 38.30 & $14,599,746$ & 42.20 & $2,900,000$ & 22.97 & .. & - & 430,000 \\
\hline 1993 & $1,586,545$ & 38.10 & 13.162 .402 & 40.64 & $3,561,324$ & 26.21 & . & $\cdots$ & 465,000 \\
\hline 1994 & $1,490,000$ & 36.75 & 13.518 .321 & 40.95 & $3,843,953$ & 27.04 & .. & .. & 459,500 \\
\hline 1995 & $1,640,000$ & 41.30 & $9,847,550$ & 30.89 & $2,811,152$ & 22.13 & $\ldots$ & .. & 182,500 \\
\hline 1996 & $1,481,000$ & 38.00 & $9,890,463$ & 32.20 & $3,000,045$ & 23.56 & $\cdots$ & $\cdots$ & 200,000 \\
\hline 1997 & $1,446,000$ & 43.44 & $13,800,000$ & 51.91 & $3,200,000$ & 20.00 & . & .. & 25,000 \\
\hline Other ${ }^{d}$ & - & $\cdots$ & - & - & $2,300,000^{e}$ & W & 79,000 & W & - \\
\hline TOTAL & $51,275,428$ & 861.09 & $1,129,870,579$ & $2,346.82$ & $115,456,310$ & 520.78 & 856,000 & $11,417.0$ & $177,354,872$ \\
\hline
\end{tabular}

aBuilding-stone production figures for 1880-1937 are for the southcentral and interior regions of Alaska only.

bIncludes 2.4 million $\mathrm{lb} \mathrm{U}_{3} \mathrm{O}_{8}$ (1955-71); 505,000 tons gypsum (1905-26); 286,000 lb WO (intermittently 1916-80); 94,000 lb asbestos (1942-44); $540,000 \mathrm{lb}$ graphite (1917-18 and 1942-50); and undistributed amounts of zinc, jade, peat, clay, soapstone, miscellaneous gemstones, and other commodities (1880-1993).

CProduction not traceable by year.

${ }^{\mathrm{d}}$ When state (territorial) and federal figures differ significantly, state figures are used. Figures for sand and gravel production in 1974 show state estimates $(118,740,000 \mathrm{~s}$. tons; $240.94 \mathrm{~m} \$)$ and federal $(42,614,000 \mathrm{~s}$. tons; $88.96 \mathrm{~m} \$)$. The federal estimate was not added to total production.

${ }^{\mathrm{e}}$ Marble quarried on Prince of Wales Island, southeastern Alaska (1900-41).

$\mathrm{m} \$=$ Million dollars.

$\mathrm{t} \$=$ Thousand dollars.

.. = Not reported.

$\mathrm{W}=$ Withheld. 


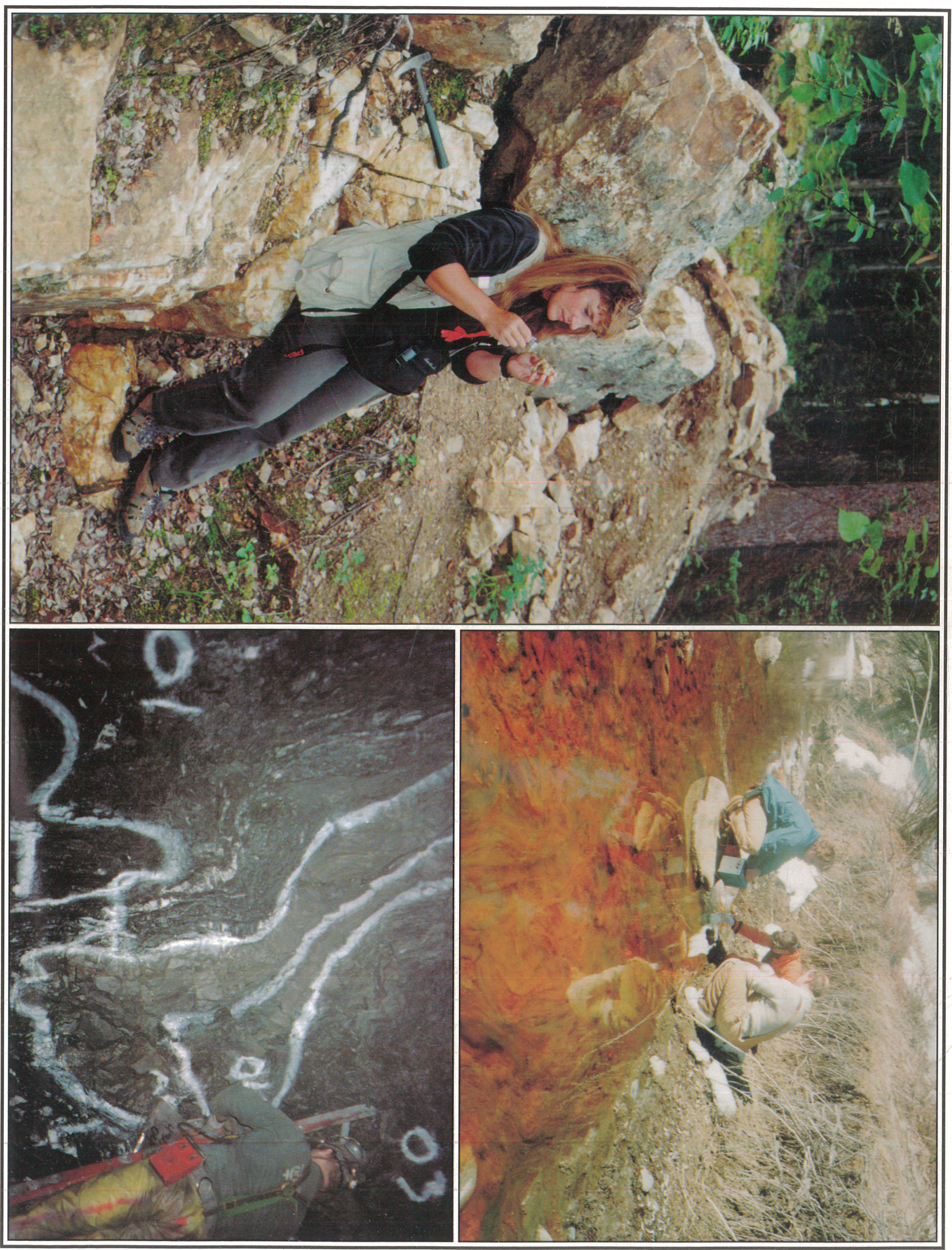

